\title{
Computational Insights into Privileged Stereocontrolling Interactions Involving Chiral Phosphates and Iminium Intermediates
}

\author{
Ali Shoja and Jolene P. Reid* \\ Correspondence to:jreid@,chem.ubc.ca \\ Department of Chemistry, University of British Columbia, 2036 Main Mall, Vancouver, British \\ Columbia, V6T 1Z1, Canada
}

\section{Table of Contents}

Full list of authors in the Gaussian reference $\quad 2$

Computational Details 3

Cartesian coordinates and energies of the TS employing the model catalyst 4

Cartesian coordinates and energies of the TS employing TRIP 11

Examination of other computational methods 44

Cartesian coordinates and energies of the re-optimized TS 57

Cartesian coordinates of reaction components 153

Out-of-sample predictions 181

References 190 


\section{Full list of authors in the Gaussian reference}

M. J. Frisch, G. W. Trucks, H. B. Schlegel, G. E. Scuseria, M. A. Robb, J. R. Cheeseman, G. Scalmani, V. Barone, G. A. Petersson, H. Nakatsuji, X. Li, M. Caricato, A. V. Marenich, J. Bloino, B. G. Janesko, R. Gomperts, B. Mennucci, H. P. Hratchian, J. V. Ortiz, A. F. Izmaylov, J. L. Sonnenberg, D. Williams-Young, F. Ding, F. Lipparini, F. Egidi, J. Goings, B. Peng, A. Petrone, T. Henderson, D. Ranasinghe, V. G. Zakrzewski, J. Gao, N. Rega, G. Zheng, W. Liang, M. Hada, M. Ehara, K. Toyota, R. Fukuda, J. Hasegawa, M. Ishida, T. Nakajima, Y. Honda, O. Kitao, H. Nakai, T. Vreven, K. Throssell, J. A. Montgomery, Jr., J. E. Peralta, F. Ogliaro, M. J. Bearpark, J. J. Heyd, E. N. Brothers, K. N. Kudin, V. N. Staroverov, T. A. Keith, R. Kobayashi, J. Normand, K. Raghavachari, A. P. Rendell, J. C. Burant, S. S. Iyengar, J. Tomasi, M. Cossi, J. M. Millam, M. Klene, C. Adamo, R. Cammi, J. W. Ochterski, R. L. Martin, K. Morokuma, O. Farkas, J. B. Foresman, and D. J. Fox, Gaussian, Inc., Wallingford CT, 2016. 


\section{Computational Details}

For the study of the reaction catalyzed by buta-1,3-diene-1,4-diol-phosphoric acid, quantum mechanical calculations were performed using Gaussian 16 (revision B.01). ${ }^{1}$ All geometries of the stationary points were obtained via unconstrained optimizations using the B3LYP density functional, ${ }^{2,3}$ and split-valence polarized $6-31 \mathrm{G}(\mathrm{d}, \mathrm{p})$ basis set. ${ }^{4,5}$ Single point energies were taken using the B3LYP density functional, and 6-311+G(d,p) basis set. This energy was used to correct the gas phase energy obtained from the B3LYP calculations.

Calculations using the TRIP catalyst system was performed using B3LYP density functional, with the 6-31G(d) basis set implemented in Gaussian 16 (revision B.01). Single point energy calculations were performed on the resulting structures using B3LYP/6-311+G(d,p). Free energies in solution were derived from structures optimized in the gas phase by means of a single point calculation using B3LYP/6-311+G(d,p) with the polarizable continuum model (IEFPCM) using dioxane. ${ }^{6}$ These single point calculations were used to correct the gas phase energy. All quoted free energies and energy differences are zero point energy corrected.

For consistency with the previous statistical model, ${ }^{7}$ the same computational methods were employed to optimize and parametrize the out-of-sample reaction components. Specifically, reaction component structures were optimized in the gas-phase with the M06-2X density functional, ${ }^{8}$ and the triple- $\zeta$ valence quality def2-TZVP basis set of Weigend and Ahlrichs, ${ }^{9}$ as implemented in Gaussian 09 (revision D.01). ${ }^{10}$ Parameters were acquired from these ground state structures. Sterimol values were calculated using a modified version of Paton's Python script. ${ }^{11}$

Conformational searches were performed with Macromodel version $11.7^{12}$ and the OPLS3 force field. ${ }^{13}$ 


\section{Cartesian coordinates and energies of the TS employing the model catalyst}

\section{TS-1}

B3LYP/6-31G(d,p) Energy = -2144.169864

B3LYP/6-31G(d,p) Free Energy $=-2143.599827$

B3LYP/6-311+G(d,p) Derived free energy $=-2144.066782$

Number of Imaginary Frequencies $=1(-1017.94)$

\begin{tabular}{|c|c|c|c|}
\hline \multicolumn{4}{|c|}{ B3LYP/6-31G(d,p) Geometry } \\
\hline $\mathrm{C}$ & 1.52429 & 1.38312 & -0.56805 \\
\hline $\mathrm{C}$ & 2.20683 & 0.16873 & -0.91988 \\
\hline $\mathrm{C}$ & 0.18780 & 1.63556 & -0.82260 \\
\hline $\mathrm{C}$ & 3.70527 & 0.28777 & -1.07294 \\
\hline $\mathrm{C}$ & 1.55298 & -0.80936 & -1.89366 \\
\hline $\mathrm{C}$ & 4.27965 & 1.48362 & -1.53454 \\
\hline $\mathrm{C}$ & 5.65545 & 1.59218 & -1.73341 \\
\hline $\mathrm{C}$ & 6.51227 & 0.51639 & -1.47834 \\
\hline $\mathrm{C}$ & 5.93786 & -0.67612 & -1.01633 \\
\hline $\mathrm{C}$ & 4.56477 & -0.79520 & -0.82137 \\
\hline $\mathrm{C}$ & 8.00006 & 0.62368 & -1.71085 \\
\hline $\mathrm{N}$ & -0.49506 & 2.75073 & -0.50737 \\
\hline $\mathrm{C}$ & 0.09133 & 3.90606 & 0.17637 \\
\hline $\mathrm{C}$ & -0.94388 & 4.54686 & 1.10647 \\
\hline $\mathrm{O}$ & -2.15046 & 4.85158 & 0.42709 \\
\hline $\mathrm{C}$ & -2.74178 & 3.66932 & -0.10338 \\
\hline $\mathrm{C}$ & -1.81689 & 2.99516 & -1.11069 \\
\hline $\mathrm{H}$ & -0.42753 & 0.89731 & -1.33160 \\
\hline $\mathrm{C}$ & 1.74634 & -1.25582 & 1.36301 \\
\hline $\mathrm{C}$ & 1.17595 & -2.56548 & 1.01814 \\
\hline $\mathrm{C}$ & -0.20037 & -2.67408 & 0.92197 \\
\hline $\mathrm{N}$ & -0.97217 & -1.61946 & 1.32340 \\
\hline $\mathrm{C}$ & -0.50553 & -0.48494 & 1.91511 \\
\hline $\mathrm{C}$ & 0.86598 & -0.28867 & 2.01213 \\
\hline $\mathrm{C}$ & -1.57249 & 0.43153 & 2.43899 \\
\hline $\mathrm{C}$ & -1.01003 & -3.84474 & 0.42370 \\
\hline $\mathrm{C}$ & 1.43127 & 0.90934 & 2.68291 \\
\hline $\mathrm{C}$ & 2.16065 & -3.65192 & 0.79329 \\
\hline $\mathrm{C}$ & 2.93649 & 0.96175 & 2.90117 \\
\hline $\mathrm{O}$ & 0.72935 & 1.84051 & 3.07428 \\
\hline $\mathrm{C}$ & 1.76041 & -5.11201 & 0.66589 \\
\hline $\mathrm{O}$ & 3.35931 & -3.37264 & 0.75197 \\
\hline $\mathrm{C}$ & -6.56171 & -1.55903 & -1.16352 \\
\hline $\mathrm{C}$ & -5.56297 & -2.01939 & -1.93632 \\
\hline $\mathrm{C}$ & -6.59269 & -0.43723 & -0.23425 \\
\hline $\mathrm{C}$ & -5.65390 & 0.49031 & 0.00547 \\
\hline $\mathrm{O}$ & -4.42570 & 0.59395 & -0.60673 \\
\hline
\end{tabular}




$\begin{array}{lrrr}\mathrm{O} & -4.28040 & -1.55597 & -2.05396 \\ \mathrm{P} & -3.46382 & -0.73535 & -0.87530 \\ \mathrm{O} & -2.19854 & -0.22848 & -1.48863 \\ \mathrm{O} & -3.44624 & -1.57667 & 0.38875 \\ \mathrm{H} & 2.11936 & 2.13826 & -0.06652 \\ \mathrm{H} & 0.49365 & -0.97355 & -1.68280 \\ \mathrm{H} & 2.06853 & -1.77288 & -1.87065 \\ \mathrm{H} & 1.64069 & -0.41702 & -2.91308 \\ \mathrm{H} & 3.64118 & 2.32989 & -1.76653 \\ \mathrm{H} & 6.06684 & 2.52993 & -2.09874 \\ \mathrm{H} & 6.57688 & -1.52814 & -0.79731 \\ \mathrm{H} & 4.16615 & -1.72915 & -0.43834 \\ \mathrm{H} & 8.29337 & 0.11623 & -2.63813 \\ \mathrm{H} & 8.56636 & 0.15816 & -0.89772 \\ \mathrm{H} & 8.31922 & 1.66644 & -1.79232 \\ \mathrm{H} & 0.42884 & 4.63938 & -0.57028 \\ \mathrm{H} & 0.94666 & 3.58658 & 0.77214 \\ \mathrm{H} & -0.55148 & 5.48965 & 1.49767 \\ \mathrm{H} & -1.13218 & 3.87074 & 1.95430 \\ \mathrm{H} & -2.99040 & 2.96711 & 0.70647 \\ \mathrm{H} & -3.67005 & 3.97012 & -0.59488 \\ \mathrm{H} & -1.68860 & 3.65869 & -1.97807 \\ \mathrm{H} & -2.23125 & 2.04007 & -1.44104 \\ \mathrm{H} & 2.07749 & -0.62419 & 0.22828 \\ \mathrm{H} & 2.76557 & -1.32798 & 1.73763 \\ \mathrm{H} & -2.00025 & -1.64123 & 1.05955 \\ \mathrm{H} & -1.50587 & 1.40406 & 1.94862 \\ \mathrm{H} & -2.55979 & 0.00073 & 2.26601 \\ \mathrm{H} & -1.42290 & 0.62242 & 3.50420 \\ \mathrm{H} & -1.08478 & -4.62675 & 1.18688 \\ \mathrm{H} & -2.02295 & -3.51177 & 0.18808 \\ \mathrm{H} & -0.57186 & -4.28748 & -0.47066 \\ \mathrm{H} & 3.17428 & 1.89203 & 3.41775 \\ \mathrm{H} & 3.27406 & 0.11487 & 3.50976 \\ \mathrm{H} & 3.48921 & 0.91842 & 1.95702 \\ & 2.66585 & -5.70850 & 0.78323 \\ \mathrm{H} & 1.33864 & -5.31956 & -0.32303 \\ \mathrm{H} & -5.81937 .50716 & -0.32379 & 0.34124 \\ \mathrm{H} & & -2.11319 & -1.26058 \\ \mathrm{H} & -2.85645 & -2.60763\end{array}$

TS-2

B3LYP/6-31G(d,p) Energy = -2144.165943

B3LYP/6-31G(d,p) Free Energy = -2143.595119 
B3LYP/6-311+G(d,p) Derived free energy $=-2144.061905$

Number of Imaginary Frequencies $=1(-960.19)$

$\begin{array}{lccc}\text { B3LYP/6-31G(d,p) Geometry } & \\ \text { C } & -0.77541 & 1.87594 & 1.78738 \\ \mathrm{C} & -2.00252 & 1.11426 & 1.70391 \\ \mathrm{C} & 0.51189 & 1.37578 & 1.77200 \\ \mathrm{C} & -3.21682 & 1.84147 & 2.28355 \\ \mathrm{~N} & 1.66119 & 2.07116 & 1.78727 \\ \mathrm{C} & 1.75227 & 3.53230 & 1.77567 \\ \mathrm{C} & 2.84097 & 3.98158 & 0.79500 \\ \mathrm{O} & 4.08229 & 3.35118 & 1.06894 \\ \mathrm{C} & 3.96391 & 1.93829 & 0.94134 \\ \mathrm{C} & 2.94807 & 1.37591 & 1.93286 \\ \mathrm{H} & 0.67324 & 0.30547 & 1.75689 \\ \mathrm{C} & -2.57300 & 1.41614 & -0.93550 \\ \mathrm{C} & -2.94372 & 0.10155 & -1.45792 \\ \mathrm{C} & -1.95873 & -0.65895 & -2.06047 \\ \mathrm{~N} & -0.73257 & -0.09017 & -2.28129 \\ \mathrm{C} & -0.40912 & 1.21255 & -2.04151 \\ \mathrm{C} & -1.34336 & 2.03163 & -1.42038 \\ \mathrm{C} & 0.95270 & 1.61775 & -2.52130 \\ \mathrm{C} & -2.04183 & -2.09181 & -2.52090 \\ \mathrm{C} & -1.09079 & 3.47781 & -1.20810 \\ \mathrm{C} & -4.34727 & -0.30032 & -1.17503 \\ \mathrm{C} & -2.28029 & 4.37276 & -0.88128 \\ \mathrm{O} & 0.02662 & 3.98207 & -1.30814 \\ \mathrm{C} & -4.98560 & -1.53242 & -1.79029 \\ \mathrm{O} & -5.02484 & 0.41004 & -0.43437 \\ \mathrm{C} & 4.06766 & -3.20843 & 0.80795 \\ \mathrm{C} & 2.83260 & -3.62084 & 0.47081 \\ \mathrm{C} & 4.95047 & -2.24405 & 0.16266 \\ \mathrm{C} & 4.77755 & -1.58244 & -0.99322 \\ \mathrm{O} & 3.70285 & -1.67808 & -1.83965 \\ \mathrm{O} & 2.04672 & -3.22590 & -0.57820 \\ \mathrm{P} & 2.14703 & -1.71842 & -1.27736 \\ \mathrm{O} & 1.93338 & -0.66007 & -0.23311 \\ \mathrm{O} & 1.27674 & -1.79630 & -2.50939 \\ \mathrm{H} & -0.91131 & 2.95082 & 1.85618 \\ \mathrm{H} & 1.99193 & 3.88731 & 2.78796 \\ \mathrm{H} & 0.79997 & 3.96204 & 1.46643 \\ \mathrm{H} & 3.00191 & 5.05893 & 0.89194 \\ \mathrm{H} & 2.50732 & 3.76748 & -0.23054 \\ \mathrm{H} & 3.66266 & 1.66041 & -0.07843 \\ \mathrm{H} & 4.95220 & 1.51597 & 1.14063 \\ \mathrm{H} & 3.31729 & 1.52076 & 2.95820 \\ & & & \\ & & & \end{array}$




$\begin{array}{lrrr}\mathrm{H} & 2.79754 & 0.31456 & 1.73132 \\ \mathrm{H} & -2.33440 & 1.21480 & 0.36859 \\ \mathrm{H} & -3.43020 & 2.06702 & -0.77771 \\ \mathrm{H} & 0.06745 & -0.74170 & -2.52676 \\ \mathrm{H} & 1.63603 & 1.64970 & -1.66815 \\ \mathrm{H} & 1.33634 & 0.88500 & -3.23289 \\ \mathrm{H} & 0.93292 & 2.61407 & -2.96117 \\ \mathrm{H} & -2.57237 & -2.16938 & -3.47614 \\ \mathrm{H} & -1.03409 & -2.48933 & -2.66075 \\ \mathrm{H} & -2.56018 & -2.71511 & -1.79273 \\ \mathrm{H} & -3.08378 & 4.25536 & -1.61643 \\ \mathrm{H} & -1.93583 & 5.40728 & -0.87859 \\ \mathrm{H} & -2.70630 & 4.13806 & 0.09959 \\ \mathrm{H} & -4.66258 & -2.43625 & -1.26255 \\ \mathrm{H} & -4.73696 & -1.65644 & -2.84685 \\ \mathrm{H} & -6.06575 & -1.43711 & -1.67212 \\ \mathrm{H} & 5.54045 & -0.91593 & -1.38416 \\ \mathrm{H} & 5.89194 & -2.04970 & 0.66902 \\ \mathrm{H} & 4.47003 & -3.69047 & 1.69464 \\ \mathrm{H} & 2.33558 & -4.39057 & 1.05339 \\ \mathrm{C} & -2.05920 & -3.22116 & 2.12426 \\ \mathrm{C} & -2.95407 & -2.40599 & 2.82948 \\ \mathrm{C} & -2.93697 & -1.02079 & 2.69032 \\ \mathrm{C} & -2.01081 & -0.38211 & 1.84515 \\ \mathrm{C} & -1.13084 & -1.20639 & 1.11851 \\ \mathrm{C} & -1.15160 & -2.59284 & 1.26315 \\ \mathrm{H} & -3.67887 & -2.86120 & 3.50009 \\ \mathrm{H} & -3.65046 & -0.43595 & 3.25880 \\ \mathrm{H} & -0.40805 & -0.78189 & 0.43127 \\ \mathrm{H} & -0.44386 & -3.18576 & 0.68961 \\ \mathrm{H} & -3.21694 & 1.77557 & 3.37771 \\ \mathrm{H} & -4.15155 & 1.42729 & 1.90055 \\ \mathrm{H} & -3.18261 & 2.90424 & 2.02912 \\ \mathrm{C} & -2.05952 & -4.71971 & 2.30478 \\ \mathrm{H} & -1.42601 & -5.01422 & 3.15093 \\ \mathrm{H} & -3.06535 & -5.10026 & 2.50750 \\ & -1.67289 & -5.22993 & 1.41794\end{array}$

\section{TS-3}

B3LYP/6-31G(d,p) Energy = -2144.165903

B3LYP/6-31G(d,p) Free Energy $=-2143.596054$

B3LYP/6-311+G(d,p) Derived free energy $=-2144.064201$

Number of Imaginary Frequencies $=1(-912.40)$

B3LYP/6-31G(d,p) Geometry

$\begin{array}{llll}\text { C } & 0.89002 & -1.45980 & -1.33091\end{array}$ 


\begin{tabular}{|c|c|c|c|}
\hline $\mathrm{C}$ & -0.26993 & -2.31767 & -1.21889 \\
\hline $\mathrm{C}$ & 2.18695 & -1.90872 & -1.28397 \\
\hline $\mathrm{C}$ & -1.57336 & -1.72505 & -1.66423 \\
\hline $\mathrm{C}$ & -0.08138 & -3.81733 & -1.43037 \\
\hline $\mathrm{C}$ & -1.83619 & -0.34808 & -1.50577 \\
\hline $\mathrm{C}$ & -3.05012 & 0.20011 & -1.90606 \\
\hline $\mathrm{C}$ & -4.05979 & -0.58981 & -2.47295 \\
\hline $\mathrm{C}$ & -3.80020 & -1.95593 & -2.63377 \\
\hline $\mathrm{C}$ & -2.58874 & -2.51516 & -2.23291 \\
\hline $\mathrm{C}$ & -5.38455 & 0.00935 & -2.87504 \\
\hline $\mathrm{N}$ & 3.31596 & -1.16489 & -1.40302 \\
\hline $\mathrm{C}$ & 4.59570 & -1.82867 & -1.66509 \\
\hline $\mathrm{C}$ & 5.74120 & -1.03107 & -1.04221 \\
\hline $\mathrm{O}$ & 5.73561 & 0.30852 & -1.50022 \\
\hline $\mathrm{C}$ & 4.51694 & 0.95684 & -1.14792 \\
\hline $\mathrm{C}$ & 3.29735 & 0.26371 & -1.75069 \\
\hline $\mathrm{H}$ & 2.38991 & -2.96646 & -1.14495 \\
\hline $\mathrm{C}$ & -0.63494 & -2.34966 & 1.47847 \\
\hline $\mathrm{C}$ & -1.84211 & -1.58833 & 1.79059 \\
\hline $\mathrm{C}$ & -1.70137 & -0.23086 & 2.03424 \\
\hline $\mathrm{N}$ & -0.44145 & 0.29032 & 2.13919 \\
\hline $\mathrm{C}$ & 0.71406 & -0.43450 & 2.15958 \\
\hline $\mathrm{C}$ & 0.64878 & -1.79774 & 1.91740 \\
\hline $\mathrm{C}$ & 1.93711 & 0.39135 & 2.46245 \\
\hline $\mathrm{C}$ & -2.80845 & 0.76727 & 2.21414 \\
\hline $\mathrm{C}$ & 1.76715 & -2.77043 & 1.96757 \\
\hline $\mathrm{C}$ & -3.17872 & -2.23710 & 1.79442 \\
\hline $\mathrm{C}$ & 3.11134 & -2.43886 & 2.59260 \\
\hline $\mathrm{O}$ & 1.59542 & -3.90295 & 1.51363 \\
\hline $\mathrm{C}$ & -3.26179 & -3.72317 & 1.47731 \\
\hline $\mathrm{O}$ & -4.20227 & -1.61789 & 2.06512 \\
\hline $\mathrm{C}$ & -1.49579 & 5.70633 & 0.09902 \\
\hline $\mathrm{C}$ & -1.92994 & 4.54171 & -0.41381 \\
\hline $\mathrm{C}$ & -0.16562 & 6.10969 & 0.53659 \\
\hline $\mathrm{C}$ & 0.99465 & 5.44717 & 0.42241 \\
\hline $\mathrm{O}$ & 1.17540 & 4.21735 & -0.16749 \\
\hline $\mathrm{O}$ & -1.23377 & 3.38854 & -0.66022 \\
\hline$P$ & 0.16125 & 2.94939 & 0.12954 \\
\hline $\mathrm{O}$ & 0.69769 & 1.76161 & -0.60479 \\
\hline $\mathrm{O}$ & -0.12647 & 2.87887 & 1.61835 \\
\hline $\mathrm{H}$ & 0.71681 & -0.39696 & -1.43971 \\
\hline $\mathrm{H}$ & 0.09106 & -4.03430 & -2.49086 \\
\hline $\mathrm{H}$ & -0.96144 & -4.37934 & -1.11123 \\
\hline $\mathrm{H}$ & 0.75636 & -4.19717 & -0.84628 \\
\hline $\mathrm{H}$ & -1.08973 & 0.31814 & -1.08441 \\
\hline $\mathrm{H}$ & -3.20303 & 1.26836 & -1.77786 \\
\hline
\end{tabular}




$\begin{array}{lrrr}\mathrm{H} & -4.55545 & -2.59467 & -3.08474 \\ \mathrm{H} & -2.43217 & -3.57537 & -2.39681 \\ \mathrm{H} & -5.25763 & 1.01063 & -3.29801 \\ \mathrm{H} & -6.05048 & 0.10600 & -2.00853 \\ \mathrm{H} & -5.89830 & -0.61115 & -3.61480 \\ \mathrm{H} & 4.76273 & -1.90188 & -2.75063 \\ \mathrm{H} & 4.56735 & -2.84194 & -1.25314 \\ \mathrm{H} & 6.70270 & -1.46510 & -1.33092 \\ \mathrm{H} & 5.65922 & -1.06283 & 0.05783 \\ \mathrm{H} & 4.41749 & 0.99478 & -0.05090 \\ \mathrm{H} & 4.58279 & 1.98096 & -1.52173 \\ \mathrm{H} & 3.31674 & 0.36653 & -2.84581 \\ \mathrm{H} & 2.39307 & 0.74333 & -1.36844 \\ \mathrm{H} & -0.51936 & -2.33801 & 0.16311 \\ \mathrm{H} & -0.68941 & -3.43052 & 1.59036 \\ \mathrm{H} & -0.34528 & 1.34294 & 2.08577 \\ \mathrm{H} & 1.69034 & 1.45124 & 2.38959 \\ \mathrm{H} & 2.30372 & 0.19313 & 3.47473 \\ \mathrm{H} & 2.74380 & 0.17707 & 1.76087 \\ \mathrm{H} & -3.55353 & 0.65528 & 1.42549 \\ \mathrm{H} & -3.33672 & 0.58342 & 3.15421 \\ \mathrm{H} & -2.40378 & 1.78138 & 2.21088 \\ \mathrm{H} & 3.65063 & -3.37720 & 2.72851 \\ \mathrm{H} & 3.69783 & -1.79246 & 1.93087 \\ \mathrm{H} & 3.01468 & -1.92721 & 3.55321 \\ \mathrm{H} & -2.68566 & -4.31876 & 2.19439 \\ \mathrm{H} & -4.30940 & -4.02095 & 1.52433 \\ \mathrm{H} & -2.86933 & -3.93816 & 0.47849 \\ \mathrm{H} & 1.93060 & 5.86928 & 0.77442 \\ \mathrm{H} & -0.09642 & 7.08510 & 1.00982 \\ \mathrm{H} & -2.26844 & 6.46456 & 0.19094 \\ \mathrm{H} & -2.96506 & 4.43340 & -0.72271 \\ & & & \\ & & & \\ & & \end{array}$

\section{TS-4}

B3LYP/6-31G(d,p) Energy $=-2144.164242$

B3LYP/6-31G(d,p) Free Energy = -2143.595324

B3LYP/6-311+G(d,p) Derived free energy $=-2144.062871$

Number of Imaginary Frequencies $=1(-991.41)$

\begin{tabular}{lccc}
\multicolumn{4}{l}{ B3LYP/6-31G(d,p) Geometry } \\
C & 0.87715 & 0.74526 & -0.83440 \\
C & 1.88884 & -0.24049 & -1.10502 \\
C & 1.07559 & 1.86089 & -0.04459 \\
C & 3.35541 & 0.12067 & -1.12855 \\
C & 1.49735 & -1.27092 & -2.16442 \\
C & 3.79258 & 1.37823 & -1.57473
\end{tabular}




\begin{tabular}{|c|c|c|c|}
\hline $\mathrm{C}$ & 5.15214 & 1.67552 & -1.67001 \\
\hline $\mathrm{C}$ & 6.12788 & 0.73402 & -1.32631 \\
\hline $\mathrm{C}$ & 5.69092 & -0.52890 & -0.90170 \\
\hline $\mathrm{C}$ & 4.33614 & -0.83627 & -0.80943 \\
\hline $\mathrm{C}$ & 7.59886 & 1.06559 & -1.39746 \\
\hline $\mathrm{N}$ & 0.17495 & 2.80521 & 0.28205 \\
\hline $\mathrm{C}$ & 0.53088 & 3.94731 & 1.12576 \\
\hline $\mathrm{C}$ & 0.15701 & 5.24959 & 0.40976 \\
\hline $\mathrm{O}$ & -1.21257 & 5.25624 & 0.04437 \\
\hline $\mathrm{C}$ & -1.52373 & 4.16940 & -0.82478 \\
\hline $\mathrm{C}$ & -1.22544 & 2.82392 & -0.16415 \\
\hline $\mathrm{H}$ & 2.06217 & 2.04656 & 0.37219 \\
\hline $\mathrm{C}$ & 1.57278 & -1.76559 & 1.12800 \\
\hline $\mathrm{C}$ & 0.85533 & -2.96423 & 0.68160 \\
\hline $\mathrm{C}$ & -0.52611 & -2.91896 & 0.66181 \\
\hline $\mathrm{N}$ & -1.15630 & -1.84007 & 1.22359 \\
\hline $\mathrm{C}$ & -0.53938 & -0.84758 & 1.92132 \\
\hline $\mathrm{C}$ & 0.85013 & -0.81753 & 1.96634 \\
\hline $\mathrm{C}$ & -1.47118 & 0.10011 & 2.62040 \\
\hline $\mathrm{C}$ & -1.48247 & -3.93278 & 0.08714 \\
\hline $\mathrm{C}$ & 1.57982 & 0.17972 & 2.78895 \\
\hline $\mathrm{C}$ & 1.72014 & -4.07557 & 0.21499 \\
\hline $\mathrm{C}$ & 3.09153 & 0.04316 & 2.90988 \\
\hline $\mathrm{O}$ & 1.00805 & & 3.38103 \\
\hline $\mathrm{C}$ & 1.18542 & -5.47226 & -0.04805 \\
\hline $\mathrm{O}$ & 2.92596 & -3.87084 & 0.06892 \\
\hline $\mathrm{C}$ & -6.70139 & -0.70446 & -0.96693 \\
\hline $\mathrm{C}$ & -5.82088 & -1.24040 & -1.82836 \\
\hline $\mathrm{C}$ & -6.52501 & 0.36463 & 0.00739 \\
\hline $\mathrm{C}$ & -5.44280 & 1.11411 & 0.27075 \\
\hline $\mathrm{O}$ & -4.21333 & 1.05357 & -0.33782 \\
\hline $\mathrm{O}$ & -4.50387 & -0.91011 & -2.01207 \\
\hline $\mathrm{P}$ & -3.50918 & -0.38000 & -0.80405 \\
\hline $\mathrm{O}$ & -2.19917 & -0.02564 & -1.42640 \\
\hline $\mathrm{O}$ & -3.59750 & -1.35155 & 0.36211 \\
\hline $\mathrm{H}$ & -0.12527 & 0.51300 & -1.18434 \\
\hline $\mathrm{H}$ & 1.63769 & -0.83105 & -3.15862 \\
\hline $\mathrm{H}$ & 0.44491 & -1.54983 & -2.06846 \\
\hline $\mathrm{H}$ & 2.12349 & -2.16408 & -2.10582 \\
\hline $\mathrm{H}$ & 3.06219 & 2.11930 & -1.88156 \\
\hline $\mathrm{H}$ & 5.45707 & 2.65568 & -2.02855 \\
\hline $\mathrm{H}$ & 6.42434 & -1.28924 & -0.64441 \\
\hline $\mathrm{H}$ & 4.03671 & -1.83241 & -0.49497 \\
\hline $\mathrm{H}$ & 7.78858 & 1.90252 & -2.07544 \\
\hline $\mathrm{H}$ & 8.18561 & 0.20884 & -1.74302 \\
\hline $\mathrm{H}$ & 7.98973 & 1.34760 & -0.41177 \\
\hline
\end{tabular}




$\begin{array}{lrrr}\mathrm{H} & 1.60064 & 3.91757 & 1.34832 \\ \mathrm{H} & -0.01686 & 3.87862 & 2.07383 \\ \mathrm{H} & 0.79529 & 5.37480 & -0.48112 \\ \mathrm{H} & 0.31301 & 6.10505 & 1.07344 \\ \mathrm{H} & -2.58965 & 4.24234 & -1.05218 \\ \mathrm{H} & -0.95487 & 4.26079 & -1.76392 \\ \mathrm{H} & -1.44125 & 1.99250 & -0.83627 \\ \mathrm{H} & -1.87110 & 2.70830 & 0.71473 \\ \mathrm{H} & 1.81605 & -1.06004 & 0.01209 \\ \mathrm{H} & 2.60976 & -1.96295 & 1.38635 \\ \mathrm{H} & -2.18508 & -1.70059 & 0.98825 \\ \mathrm{H} & -1.36668 & -0.00472 & 3.70484 \\ \mathrm{H} & -1.20603 & 1.13318 & 2.39859 \\ \mathrm{H} & -2.50305 & -0.10098 & 2.32848 \\ \mathrm{H} & -1.13117 & -4.32620 & -0.86649 \\ \mathrm{H} & -1.61904 & -4.77687 & 0.77226 \\ \mathrm{H} & -2.45752 & -3.46538 & -0.06663 \\ \mathrm{H} & 3.45257 & 0.83755 & 3.56368 \\ \mathrm{H} & 3.36537 & -0.92781 & 3.33836 \\ \mathrm{H} & 3.58958 & 0.11596 & 1.93748 \\ \mathrm{H} & 2.03718 & -6.15355 & -0.05995 \\ \mathrm{H} & 0.69597 & -5.52279 & -1.02661 \\ \mathrm{H} & 0.46080 & -5.79585 & 0.70269 \\ \mathrm{H} & -5.47734 & 1.90217 & 1.01692 \\ \mathrm{H} & -7.39866 & 0.60408 & 0.60715 \\ \mathrm{H} & -7.69835 & -1.13285 & -1.01879 \\ \mathrm{H} & -6.12513 & -2.01815 & -2.52189\end{array}$

Cartesian coordinates and energies of the TS employing TRIP

\section{TS5-E}

B3LYP/6-31G(d) Energy $=-3928.463758$

B3LYP/6-31G(d) Free Energy = -3927.085933

B3LYP/6-311+G(d,p) Derived free energy $=-3928.037005$

B3LYP/6-311+G(d,p) Derived free energy in solution $=-3928.048203$

Number of Imaginary Frequencies $=1(-1034.94)$

\begin{tabular}{|c|c|c|c|}
\hline \multicolumn{4}{|c|}{ YP/6-31G(d) Geometry } \\
\hline $\mathrm{C}$ & 4.10876 & 1.42212 & 1.36844 \\
\hline $\mathrm{C}$ & 4.75432 & 0.41989 & 0.56817 \\
\hline$C$ & 2.75727 & 1.46021 & 1.67194 \\
\hline$C$ & 6.24869 & 0.30242 & 0.76155 \\
\hline & 4.05737 & -0.91350 & 0.30940 \\
\hline & 7.10138 & -0.09980 & -0.28011 \\
\hline & 8.46849 & -0.25251 & -0.06364 \\
\hline $\mathrm{C}$ & 9.04240 & -0.01983 & 1.19395 \\
\hline
\end{tabular}




\begin{tabular}{|c|c|c|c|}
\hline $\mathrm{C}$ & 8.19041 & 0.36889 & 2.23346 \\
\hline $\mathrm{C}$ & 6.82143 & 0.53103 & 2.02358 \\
\hline $\mathrm{C}$ & 10.53011 & -0.16459 & 1.41026 \\
\hline $\mathrm{N}$ & 2.12514 & 2.37831 & 2.42251 \\
\hline $\mathrm{C}$ & 2.76885 & 3.50297 & 3.10576 \\
\hline $\mathrm{C}$ & 2.55502 & 3.36569 & 4.61890 \\
\hline $\mathrm{O}$ & 1.17880 & 3.26221 & 4.93843 \\
\hline $\mathrm{C}$ & 0.57775 & 2.13845 & 4.30061 \\
\hline $\mathrm{C}$ & 0.70471 & 2.23295 & 2.77919 \\
\hline $\mathrm{H}$ & 2.08512 & 0.69144 & 1.29613 \\
\hline $\mathrm{C}$ & 4.31543 & 1.51864 & -1.89451 \\
\hline $\mathrm{C}$ & 3.45261 & 2.60608 & -1.44458 \\
\hline $\mathrm{C}$ & 2.07818 & 2.40673 & -1.48873 \\
\hline $\mathrm{N}$ & 1.59789 & 1.26847 & -2.06581 \\
\hline $\mathrm{C}$ & 2.34648 & 0.35257 & -2.75797 \\
\hline $\mathrm{C}$ & 3.72118 & 0.50035 & -2.77050 \\
\hline $\mathrm{C}$ & 1.51888 & -0.71868 & -3.42289 \\
\hline $\mathrm{C}$ & 1.02557 & 3.35142 & -0.98582 \\
\hline $\mathrm{C}$ & 4.68552 & -0.29945 & -3.56712 \\
\hline $\mathrm{C}$ & 4.03959 & 3.84809 & -0.87789 \\
\hline $\mathrm{C}$ & 4.25428 & -1.20718 & -4.70668 \\
\hline $\mathrm{O}$ & 5.88831 & -0.19380 & -3.32716 \\
\hline $\mathrm{C}$ & 5.54964 & 4.02846 & -0.96588 \\
\hline $\mathrm{O}$ & 3.35317 & 4.72697 & -0.36302 \\
\hline $\mathrm{C}$ & -6.17019 & -2.41337 & -0.97689 \\
\hline $\mathrm{C}$ & -5.56501 & -1.14629 & -0.74687 \\
\hline $\mathrm{C}$ & -6.22779 & 0.01462 & -1.25943 \\
\hline $\mathrm{C}$ & -7.47713 & -0.12610 & -1.92171 \\
\hline $\mathrm{C}$ & -8.04429 & -1.36533 & -2.10760 \\
\hline $\mathrm{C}$ & -7.37295 & -2.51939 & -1.64022 \\
\hline $\mathrm{C}$ & -4.31055 & -0.98518 & -0.06001 \\
\hline $\mathrm{C}$ & -3.71144 & 0.26777 & -0.05701 \\
\hline $\mathrm{C}$ & -4.36228 & 1.43742 & -0.55470 \\
\hline $\mathrm{C}$ & -5.61517 & 1.28395 & -1.11074 \\
\hline $\mathrm{C}$ & -3.64830 & -2.13498 & 0.62103 \\
\hline $\mathrm{C}$ & -4.33380 & -2.90217 & 1.62724 \\
\hline $\mathrm{C}$ & -3.71754 & -4.09142 & 2.13329 \\
\hline $\mathrm{C}$ & -2.43376 & -4.46043 & 1.65957 \\
\hline $\mathrm{C}$ & -1.71884 & -3.67223 & 0.78204 \\
\hline $\mathrm{C}$ & -2.34283 & -2.48306 & 0.29631 \\
\hline $\mathrm{C}$ & -5.59027 & -2.51966 & 2.17480 \\
\hline $\mathrm{C}$ & -6.21198 & -3.28525 & 3.13667 \\
\hline $\mathrm{C}$ & -5.61765 & -4.48113 & 3.60345 \\
\hline $\mathrm{C}$ & -4.39352 & -4.86995 & 3.11119 \\
\hline $\mathrm{C}$ & -3.74189 & 2.79971 & -0.44968 \\
\hline $\mathrm{O}$ & -1.64416 & -1.71630 & -0.61457 \\
\hline
\end{tabular}




\begin{tabular}{|c|c|c|c|}
\hline $\mathrm{O}$ & -2.46869 & 0.41421 & 0.53341 \\
\hline $\mathrm{C}$ & -0.34368 & -4.07934 & 0.34297 \\
\hline $\mathrm{C}$ & -3.67518 & 3.44560 & 0.80649 \\
\hline $\mathrm{C}$ & -3.13117 & 4.73333 & 0.87971 \\
\hline $\mathrm{C}$ & -2.66864 & 5.41481 & -0.24686 \\
\hline $\mathrm{C}$ & -2.75958 & 4.76307 & -1.48007 \\
\hline $\mathrm{C}$ & -3.28402 & 3.47155 & -1.61081 \\
\hline $\mathrm{C}$ & 0.73820 & -4.02771 & 1.25249 \\
\hline $\mathrm{C}$ & 2.00215 & -4.45245 & 0.82112 \\
\hline $\mathrm{C}$ & 2.23343 & -4.92929 & -0.46909 \\
\hline $\mathrm{C}$ & 1.14590 & -4.98030 & -1.34637 \\
\hline $\mathrm{C}$ & -0.13631 & -4.57038 & -0.96930 \\
\hline $\mathrm{P}$ & -1.12474 & -0.18561 & -0.23303 \\
\hline $\mathrm{O}$ & -0.01578 & -0.18749 & 0.77727 \\
\hline $\mathrm{O}$ & -0.93456 & 0.49102 & -1.57439 \\
\hline $\mathrm{C}$ & -1.27945 & -4.72908 & -1.97212 \\
\hline $\mathrm{C}$ & -1.53674 & -6.21591 & -2.28937 \\
\hline $\mathrm{C}$ & -1.04785 & -3.91800 & -3.25992 \\
\hline $\mathrm{C}$ & 3.61760 & -5.41082 & -0.88547 \\
\hline $\mathrm{C}$ & 4.15881 & -4.65157 & -2.11097 \\
\hline $\mathrm{C}$ & 3.63857 & -6.93203 & -1.13109 \\
\hline $\mathrm{C}$ & 0.58343 & -3.54924 & 2.69699 \\
\hline $\mathrm{C}$ & 1.49266 & -2.34888 & 3.01600 \\
\hline $\mathrm{C}$ & 0.81448 & -4.70048 & 3.69578 \\
\hline $\mathrm{C}$ & -2.13326 & 6.83677 & -0.12925 \\
\hline $\mathrm{C}$ & -3.06776 & 7.84799 & -0.82198 \\
\hline $\mathrm{C}$ & -0.69254 & 6.97434 & -0.65418 \\
\hline $\mathrm{C}$ & -3.38857 & 2.86348 & -3.01155 \\
\hline $\mathrm{C}$ & -2.04722 & 2.85310 & -3.76646 \\
\hline $\mathrm{C}$ & -4.47153 & 3.58296 & -3.84166 \\
\hline $\mathrm{C}$ & -4.23562 & 2.81508 & 2.08134 \\
\hline $\mathrm{C}$ & -5.41986 & 3.63237 & 2.63487 \\
\hline $\mathrm{C}$ & -3.15234 & 2.60905 & 3.15543 \\
\hline $\mathrm{H}$ & 4.74894 & 2.22280 & 1.72362 \\
\hline $\mathrm{H}$ & 4.13276 & -1.54228 & 1.20401 \\
\hline $\mathrm{H}$ & 4.54762 & -1.44928 & -0.50887 \\
\hline $\mathrm{H}$ & 2.99758 & -0.80398 & 0.06546 \\
\hline $\mathrm{H}$ & 6.70266 & -0.27115 & -1.27561 \\
\hline $\mathrm{H}$ & 9.10280 & -0.55621 & -0.89366 \\
\hline $\mathrm{H}$ & 8.59996 & 0.54146 & 3.22643 \\
\hline $\mathrm{H}$ & 6.18457 & 0.80732 & 2.85870 \\
\hline $\mathrm{H}$ & 10.77063 & -0.29513 & 2.47036 \\
\hline $\mathrm{H}$ & 11.07133 & 0.72399 & 1.05856 \\
\hline $\mathrm{H}$ & 10.93306 & -1.02381 & 0.86267 \\
\hline $\mathrm{H}$ & 2.30869 & 4.43191 & 2.74848 \\
\hline $\mathrm{H}$ & 3.83146 & 3.54259 & 2.86827 \\
\hline
\end{tabular}




\begin{tabular}{|c|c|c|c|}
\hline $\mathrm{H}$ & 3.10393 & 2.48270 & 4.98776 \\
\hline $\mathrm{H}$ & 2.93238 & 4.25321 & 5.13583 \\
\hline $\mathrm{H}$ & 1.04325 & 1.20493 & 4.65702 \\
\hline $\mathrm{H}$ & -0.47480 & 2.14093 & 4.59422 \\
\hline $\mathrm{H}$ & 0.16592 & 3.12263 & 2.42834 \\
\hline $\mathrm{H}$ & 0.29194 & 1.35382 & 2.27600 \\
\hline $\mathrm{H}$ & 4.65221 & 0.92617 & -0.73652 \\
\hline $\mathrm{H}$ & 5.33177 & 1.78070 & -2.18267 \\
\hline $\mathrm{H}$ & 0.58018 & 1.04235 & -1.92130 \\
\hline $\mathrm{H}$ & 1.93592 & -1.71332 & -3.25388 \\
\hline $\mathrm{H}$ & 0.50267 & -0.70017 & -3.02249 \\
\hline $\mathrm{H}$ & 1.45494 & -0.55660 & -4.50469 \\
\hline $\mathrm{H}$ & 0.02981 & 2.92022 & -1.10309 \\
\hline $\mathrm{H}$ & 1.20301 & 3.60127 & 0.06139 \\
\hline $\mathrm{H}$ & 1.07745 & 4.29925 & -1.53004 \\
\hline $\mathrm{H}$ & 5.14792 & -1.45804 & -5.28139 \\
\hline $\mathrm{H}$ & 3.81765 & -2.13747 & -4.32627 \\
\hline $\mathrm{H}$ & 3.51499 & -0.73718 & -5.36164 \\
\hline $\mathrm{H}$ & 5.80740 & 4.98043 & -0.49842 \\
\hline $\mathrm{H}$ & 5.88317 & 4.04131 & -2.01125 \\
\hline $\mathrm{H}$ & 6.09232 & 3.21818 & -0.46580 \\
\hline $\mathrm{H}$ & -5.66622 & -3.30944 & -0.63435 \\
\hline $\mathrm{H}$ & -7.96998 & 0.76948 & -2.29314 \\
\hline $\mathrm{H}$ & -8.99633 & -1.46207 & -2.62244 \\
\hline $\mathrm{H}$ & -7.80764 & -3.50086 & -1.81021 \\
\hline $\mathrm{H}$ & -6.14534 & 2.16197 & -1.47068 \\
\hline $\mathrm{H}$ & -1.98981 & -5.38362 & 2.02400 \\
\hline $\mathrm{H}$ & -6.05642 & -1.60199 & 1.83560 \\
\hline $\mathrm{H}$ & -7.16688 & -2.96403 & 3.54422 \\
\hline $\mathrm{H}$ & -6.12220 & -5.08013 & 4.35672 \\
\hline $\mathrm{H}$ & -3.91356 & -5.77603 & 3.47400 \\
\hline $\mathrm{H}$ & -3.08691 & 5.23321 & 1.84540 \\
\hline $\mathrm{H}$ & -2.42299 & 5.28001 & -2.37546 \\
\hline $\mathrm{H}$ & 2.83521 & -4.41882 & 1.52045 \\
\hline $\mathrm{H}$ & 1.29363 & -5.36991 & -2.35108 \\
\hline $\mathrm{H}$ & -2.19221 & -4.34126 & -1.51235 \\
\hline $\mathrm{H}$ & -1.74672 & -6.78479 & -1.37668 \\
\hline $\mathrm{H}$ & -2.39696 & -6.32130 & -2.96162 \\
\hline $\mathrm{H}$ & -0.67203 & -6.67950 & -2.77928 \\
\hline $\mathrm{H}$ & -0.93556 & -2.85461 & -3.02958 \\
\hline $\mathrm{H}$ & -0.15274 & -4.25597 & -3.79700 \\
\hline $\mathrm{H}$ & -1.90153 & -4.03038 & -3.93924 \\
\hline $\mathrm{H}$ & 4.29704 & -5.20439 & -0.04706 \\
\hline $\mathrm{H}$ & 4.18165 & -3.57124 & -1.92658 \\
\hline $\mathrm{H}$ & 5.17827 & -4.97614 & -2.35114 \\
\hline $\mathrm{H}$ & 3.53708 & -4.83017 & -2.99685 \\
\hline
\end{tabular}




$\begin{array}{lrrr}\mathrm{H} & 3.29522 & -7.47861 & -0.24615 \\ \mathrm{H} & 2.98417 & -7.20715 & -1.96683 \\ \mathrm{H} & 4.65241 & -7.27380 & -1.37291 \\ \mathrm{H} & -0.44479 & -3.20420 & 2.82969 \\ \mathrm{H} & 1.26807 & -1.52167 & 2.33754 \\ \mathrm{H} & 1.32212 & -2.01234 & 4.04693 \\ \mathrm{H} & 2.55554 & -2.60649 & 2.92780 \\ \mathrm{H} & 0.13549 & -5.53968 & 3.50624 \\ \mathrm{H} & 1.83971 & -5.08535 & 3.63478 \\ \mathrm{H} & 0.64839 & -4.35582 & 4.72378 \\ \mathrm{H} & -2.11738 & 7.08635 & 0.94082 \\ \mathrm{H} & -4.08568 & 7.78356 & -0.42235 \\ \mathrm{H} & -3.12121 & 7.66203 & -1.90136 \\ \mathrm{H} & -2.70679 & 8.87355 & -0.67683 \\ \mathrm{H} & -0.63504 & 6.75022 & -1.72614 \\ \mathrm{H} & -0.32580 & 7.99802 & -0.51168 \\ \mathrm{H} & -0.00931 & 6.29502 & -0.13319 \\ \mathrm{H} & -3.69273 & 1.81936 & -2.90409 \\ \mathrm{H} & -1.31247 & 2.25691 & -3.22103 \\ \mathrm{H} & -2.18180 & 2.40331 & -4.75810 \\ \mathrm{H} & -1.64837 & 3.86359 & -3.91754 \\ \mathrm{H} & -5.44641 & 3.55950 & -3.34213 \\ \mathrm{H} & -4.21159 & 4.63574 & -4.00700 \\ \mathrm{H} & -4.58267 & 3.10733 & -4.82378 \\ \mathrm{H} & -4.62504 & 1.82527 & 1.82886 \\ \mathrm{H} & -6.20919 & 3.74327 & 1.88301 \\ \mathrm{H} & -5.85225 & 3.13462 & 3.51143 \\ \mathrm{H} & -5.10887 & 4.63777 & 2.94253 \\ \mathrm{H} & -2.35611 & 1.96513 & 2.77041 \\ \mathrm{H} & -2.71142 & 3.56210 & 3.47322 \\ \mathrm{H} & -3.58174 & 2.12971 & 4.04389\end{array}$

\section{TS5-Z}

B3LYP/6-31G(d) Energy = -3928.454673

B3LYP/6-31G(d) Free Energy = -3927.076557

B3LYP/6-311+G(d,p) Derived free energy $=-3928.026637$

B3LYP/6-311+G(d,p) Derived free energy in solution $=-3928.037918$

Number of Imaginary Frequencies $=1$ (-949.95)

\begin{tabular}{llrl}
\multicolumn{4}{l}{ B3LYP/6-31G(d) Geometry } \\
C & -3.95715 & -2.17648 & 2.46177 \\
C & -5.06334 & -1.98975 & 1.55126 \\
C & -2.93847 & -1.28319 & 2.72676 \\
N & -1.93606 & -1.42403 & 3.61486 \\
C & -1.81666 & -2.53568 & 4.55796 \\
C & -0.35230 & -2.97115 & 4.67662
\end{tabular}




\begin{tabular}{|c|c|c|c|}
\hline $\mathrm{O}$ & 0.49511 & -1.88762 & 4.99845 \\
\hline $\mathrm{C}$ & 0.42508 & -0.86945 & 3.99943 \\
\hline $\mathrm{C}$ & -0.99232 & -0.32170 & 3.86097 \\
\hline $\mathrm{H}$ & -2.89763 & -0.33857 & 2.19784 \\
\hline $\mathrm{C}$ & -4.16040 & -3.34748 & -0.64437 \\
\hline $\mathrm{C}$ & -2.87383 & -3.82128 & -0.12523 \\
\hline $\mathrm{C}$ & -1.73394 & -3.10699 & -0.45804 \\
\hline $\mathrm{N}$ & -1.84045 & -2.09266 & -1.36785 \\
\hline $\mathrm{C}$ & -2.95594 & -1.80733 & -2.10898 \\
\hline $\mathrm{C}$ & -4.13292 & -2.48115 & -1.82359 \\
\hline $\mathrm{C}$ & -2.74823 & -0.76883 & -3.17456 \\
\hline $\mathrm{C}$ & -0.34115 & -3.30441 & 0.07672 \\
\hline $\mathrm{C}$ & -5.34511 & -2.29450 & -2.66303 \\
\hline $\mathrm{C}$ & -2.96111 & -4.98878 & 0.78772 \\
\hline $\mathrm{C}$ & -6.63034 & -2.99369 & -2.24277 \\
\hline $\mathrm{O}$ & -5.33432 & -1.60976 & -3.68020 \\
\hline $\mathrm{C}$ & -1.74113 & -5.77280 & 1.24262 \\
\hline $\mathrm{O}$ & -4.07165 & -5.36663 & 1.16273 \\
\hline $\mathrm{C}$ & 4.72985 & 2.59180 & 2.53642 \\
\hline $\mathrm{C}$ & 3.56454 & 3.00299 & 1.83217 \\
\hline $\mathrm{C}$ & 2.90290 & 4.19748 & 2.26219 \\
\hline $\mathrm{C}$ & 3.44602 & 4.94675 & 3.34055 \\
\hline $\mathrm{C}$ & 4.58143 & 4.52595 & 3.99393 \\
\hline $\mathrm{C}$ & 5.22095 & 3.32974 & 3.59109 \\
\hline $\mathrm{C}$ & 3.01123 & 2.25896 & 0.73426 \\
\hline $\mathrm{C}$ & 1.76082 & 2.62190 & 0.25081 \\
\hline $\mathrm{C}$ & 1.12267 & 3.84638 & 0.61394 \\
\hline $\mathrm{C}$ & 1.72406 & 4.61230 & 1.59244 \\
\hline $\mathrm{C}$ & 3.77186 & 1.16575 & 0.06420 \\
\hline $\mathrm{C}$ & 5.07198 & 1.43209 & -0.49584 \\
\hline $\mathrm{C}$ & 5.81420 & 0.35038 & -1.06644 \\
\hline $\mathrm{C}$ & 5.22656 & -0.93651 & -1.11280 \\
\hline $\mathrm{C}$ & 3.94032 & -1.18238 & -0.67700 \\
\hline $\mathrm{C}$ & 3.21372 & -0.09810 & -0.09458 \\
\hline $\mathrm{C}$ & 5.65303 & 2.73106 & -0.54794 \\
\hline $\mathrm{C}$ & 6.90319 & 2.93302 & -1.09014 \\
\hline $\mathrm{C}$ & 7.65035 & 1.85062 & -1.61075 \\
\hline $\mathrm{C}$ & 7.10921 & 0.58660 & -1.60154 \\
\hline $\mathrm{C}$ & -0.11042 & 4.34244 & -0.08142 \\
\hline $\mathrm{O}$ & 1.95379 & -0.34767 & 0.41275 \\
\hline $\mathrm{O}$ & 1.15433 & 1.82776 & -0.70223 \\
\hline $\mathrm{C}$ & 3.40232 & -2.57798 & -0.82682 \\
\hline $\mathrm{C}$ & -1.32474 & 4.48993 & 0.62824 \\
\hline $\mathrm{C}$ & -2.43215 & 5.04248 & -0.03020 \\
\hline $\mathrm{C}$ & -2.38348 & 5.45410 & -1.36200 \\
\hline $\mathrm{C}$ & -1.17538 & 5.29057 & -2.04471 \\
\hline
\end{tabular}




\begin{tabular}{|c|c|c|c|}
\hline $\mathrm{C}$ & -0.03921 & 4.74816 & -1.43867 \\
\hline $\mathrm{C}$ & 2.98949 & -3.04086 & -2.10005 \\
\hline $\mathrm{C}$ & 2.66120 & -4.39362 & -2.25265 \\
\hline $\mathrm{C}$ & 2.72361 & -5.30281 & -1.19364 \\
\hline $\mathrm{C}$ & 3.10854 & -4.81576 & 0.05834 \\
\hline $\mathrm{C}$ & 3.45121 & -3.47396 & 0.26619 \\
\hline$P$ & 0.57858 & 0.33565 & -0.25433 \\
\hline $\mathrm{O}$ & 0.25626 & -0.36507 & -1.55576 \\
\hline $\mathrm{O}$ & -0.43243 & 0.40329 & 0.84965 \\
\hline $\mathrm{C}$ & 3.94833 & -3.02897 & 1.64142 \\
\hline $\mathrm{C}$ & 5.43523 & -3.39297 & 1.82948 \\
\hline $\mathrm{C}$ & 3.10535 & -3.58520 & 2.80138 \\
\hline $\mathrm{C}$ & 2.44470 & -6.78825 & -1.39378 \\
\hline $\mathrm{C}$ & 3.59700 & -7.46748 & -2.16092 \\
\hline $\mathrm{C}$ & 1.09758 & -7.06430 & -2.08456 \\
\hline $\mathrm{C}$ & 2.93964 & -2.12844 & -3.32722 \\
\hline $\mathrm{C}$ & 1.58951 & -2.19195 & -4.06374 \\
\hline $\mathrm{C}$ & 4.09935 & -2.44029 & -4.29499 \\
\hline $\mathrm{C}$ & -3.59457 & 6.09171 & -2.03105 \\
\hline $\mathrm{C}$ & -4.01479 & 5.35414 & -3.31554 \\
\hline $\mathrm{C}$ & -3.35880 & 7.58903 & -2.31093 \\
\hline $\mathrm{C}$ & 1.24494 & 4.66503 & -2.26460 \\
\hline $\mathrm{C}$ & 1.74151 & 6.06681 & -2.67195 \\
\hline $\mathrm{C}$ & 1.08005 & 3.75214 & -3.49453 \\
\hline $\mathrm{C}$ & -1.48735 & 4.06503 & 2.08781 \\
\hline $\mathrm{C}$ & -2.56107 & 2.97324 & 2.24166 \\
\hline $\mathrm{C}$ & -1.78319 & 5.26694 & 3.00562 \\
\hline $\mathrm{H}$ & -3.97320 & -3.12370 & 2.99094 \\
\hline $\mathrm{H}$ & -2.42478 & -3.37910 & 4.22739 \\
\hline $\mathrm{H}$ & -2.18515 & -2.21074 & 5.54201 \\
\hline $\mathrm{H}$ & -0.24785 & -3.70751 & 5.47938 \\
\hline $\mathrm{H}$ & -0.03375 & -3.44026 & 3.73043 \\
\hline $\mathrm{H}$ & 1.10403 & -0.07445 & 4.31741 \\
\hline $\mathrm{H}$ & 0.76779 & -1.25138 & 3.02786 \\
\hline $\mathrm{H}$ & -1.02193 & 0.36499 & 3.01407 \\
\hline $\mathrm{H}$ & -1.28339 & 0.19589 & 4.78679 \\
\hline $\mathrm{H}$ & -4.64039 & -2.64761 & 0.36793 \\
\hline $\mathrm{H}$ & -4.93179 & -4.11589 & -0.62303 \\
\hline $\mathrm{H}$ & -1.00649 & -1.46447 & -1.48934 \\
\hline $\mathrm{H}$ & -2.79607 & -1.22731 & -4.16758 \\
\hline $\mathrm{H}$ & -3.54867 & -0.02686 & -3.14934 \\
\hline $\mathrm{H}$ & -1.77801 & -0.28308 & -3.04374 \\
\hline $\mathrm{H}$ & -0.32190 & -3.18745 & 1.16391 \\
\hline $\mathrm{H}$ & 0.05081 & -4.29463 & -0.16526 \\
\hline $\mathrm{H}$ & 0.34303 & -2.57269 & -0.35125 \\
\hline $\mathrm{H}$ & -6.50946 & -4.08365 & -2.22136 \\
\hline
\end{tabular}




\begin{tabular}{|c|c|c|c|}
\hline $\mathrm{H}$ & -6.94427 & -2.67801 & -1.24141 \\
\hline $\mathrm{H}$ & -7.40871 & -2.73520 & -2.96255 \\
\hline $\mathrm{H}$ & -1.12607 & -6.09647 & 0.39642 \\
\hline $\mathrm{H}$ & -2.09795 & -6.64953 & 1.78651 \\
\hline $\mathrm{H}$ & -1.09831 & -5.18196 & 1.90306 \\
\hline $\mathrm{H}$ & 5.22602 & 1.67382 & 2.24145 \\
\hline $\mathrm{H}$ & 2.93678 & 5.85750 & 3.64749 \\
\hline $\mathrm{H}$ & 4.98321 & 5.10298 & 4.82245 \\
\hline $\mathrm{H}$ & 6.10630 & 2.98814 & 4.12078 \\
\hline $\mathrm{H}$ & 1.27367 & 5.56149 & 1.87194 \\
\hline $\mathrm{H}$ & 5.80355 & -1.75503 & -1.53561 \\
\hline $\mathrm{H}$ & 5.09608 & 3.57754 & -0.16564 \\
\hline $\mathrm{H}$ & 7.31676 & 3.93750 & -1.12320 \\
\hline $\mathrm{H}$ & 8.63847 & 2.02313 & -2.02857 \\
\hline $\mathrm{H}$ & 7.65831 & -0.25442 & -2.01884 \\
\hline $\mathrm{H}$ & -3.36301 & 5.16518 & 0.52029 \\
\hline $\mathrm{H}$ & -1.10746 & 5.60926 & -3.08187 \\
\hline $\mathrm{H}$ & 2.36647 & -4.74763 & -3.23707 \\
\hline $\mathrm{H}$ & 3.16792 & -5.51294 & 0.89116 \\
\hline $\mathrm{H}$ & 3.87111 & -1.93875 & 1.68770 \\
\hline $\mathrm{H}$ & 6.05665 & -2.93390 & 1.05354 \\
\hline $\mathrm{H}$ & 5.79847 & -3.04649 & 2.80483 \\
\hline $\mathrm{H}$ & 5.58182 & -4.47894 & 1.78007 \\
\hline $\mathrm{H}$ & 2.04166 & -3.37534 & 2.64946 \\
\hline $\mathrm{H}$ & 3.22361 & -4.66930 & 2.91672 \\
\hline $\mathrm{H}$ & 3.40528 & -3.12164 & 3.74779 \\
\hline $\mathrm{H}$ & 2.40225 & -7.24576 & -0.39532 \\
\hline $\mathrm{H}$ & 4.55391 & -7.31636 & -1.64985 \\
\hline $\mathrm{H}$ & 3.42322 & -8.54675 & -2.25140 \\
\hline $\mathrm{H}$ & 3.69088 & -7.05538 & -3.17270 \\
\hline $\mathrm{H}$ & 0.26406 & -6.60971 & -1.53625 \\
\hline $\mathrm{H}$ & 1.07744 & -6.66564 & -3.10531 \\
\hline $\mathrm{H}$ & 0.91134 & -8.14286 & -2.14871 \\
\hline $\mathrm{H}$ & 3.06055 & -1.09738 & -2.98412 \\
\hline $\mathrm{H}$ & 0.77735 & -1.89849 & -3.39543 \\
\hline $\mathrm{H}$ & 1.59637 & -1.49507 & -4.91042 \\
\hline $\mathrm{H}$ & 1.38257 & -3.19153 & -4.46521 \\
\hline $\mathrm{H}$ & 5.07367 & -2.33765 & -3.80538 \\
\hline $\mathrm{H}$ & 4.02787 & -3.46412 & -4.68266 \\
\hline $\mathrm{H}$ & 4.07802 & -1.75562 & -5.15138 \\
\hline $\mathrm{H}$ & -4.43072 & 6.02132 & -1.32070 \\
\hline $\mathrm{H}$ & -4.20876 & 4.29357 & -3.12144 \\
\hline $\mathrm{H}$ & -3.23518 & 5.41278 & -4.08382 \\
\hline $\mathrm{H}$ & -4.92597 & 5.79743 & -3.73515 \\
\hline $\mathrm{H}$ & -2.53572 & 7.73213 & -3.02110 \\
\hline $\mathrm{H}$ & -4.25618 & 8.05109 & -2.74043 \\
\hline
\end{tabular}




$\begin{array}{lrrr}\mathrm{H} & -3.10278 & 8.12735 & -1.39187 \\ \mathrm{H} & 2.02766 & 4.22432 & -1.64276 \\ \mathrm{H} & 1.89694 & 6.70397 & -1.79387 \\ \mathrm{H} & 2.69361 & 5.99226 & -3.21125 \\ \mathrm{H} & 1.02626 & 6.57467 & -3.32987 \\ \mathrm{H} & 0.77423 & 2.74628 & -3.19337 \\ \mathrm{H} & 0.33207 & 4.14719 & -4.19293 \\ \mathrm{H} & 2.02983 & 3.67333 & -4.03748 \\ \mathrm{H} & -0.54300 & 3.62528 & 2.41801 \\ \mathrm{H} & -2.30490 & 2.10733 & 1.62419 \\ \mathrm{H} & -2.62715 & 2.65084 & 3.28913 \\ \mathrm{H} & -3.55471 & 3.32755 & 1.94436 \\ \mathrm{H} & -0.99968 & 6.02996 & 2.93411 \\ \mathrm{H} & -2.73490 & 5.74653 & 2.74710 \\ \mathrm{H} & -1.84740 & 4.94468 & 4.05227 \\ \mathrm{C} & -6.08784 & 1.86095 & -0.19585 \\ \mathrm{C} & -7.03662 & 1.08801 & 0.48345 \\ \mathrm{C} & -6.70278 & -0.14389 & 1.03979 \\ \mathrm{C} & -5.39339 & -0.65188 & 0.95921 \\ \mathrm{C} & -4.44100 & 0.12824 & 0.27431 \\ \mathrm{C} & -4.78308 & 1.35825 & -0.28393 \\ \mathrm{C} & -6.46197 & 3.17691 & -0.83255 \\ \mathrm{H} & -8.05606 & 1.45472 & 0.58004 \\ \mathrm{H} & -7.47102 & -0.70159 & 1.56424 \\ \mathrm{H} & -3.41797 & -0.21668 & 0.16784 \\ \mathrm{H} & -4.01595 & 1.93809 & -0.79109 \\ \mathrm{H} & -5.65922 & 3.91395 & -0.72535 \\ \mathrm{H} & -6.64787 & 3.05665 & -1.90801 \\ \mathrm{H} & -7.37150 & 3.59358 & -0.38764 \\ \mathrm{C} & -6.25178 & -2.89404 & 1.88314 \\ \mathrm{H} & -6.75228 & -2.54617 & 2.79589 \\ \mathrm{H} & -6.99171 & -2.90999 & 1.07815 \\ \mathrm{H} & -5.90618 & -3.91657 & 2.04799\end{array}$

\section{TS6-E}

B3LYP/6-31G(d) Energy $=-3928.455324$

B3LYP/6-31G(d) Free Energy = -3927.078673

B3LYP/6-311+G(d,p) Derived free energy $=-3928.029710$

B3LYP/6-311+G(d,p) Derived free energy in solution $=-3928.041201$

Number of Imaginary Frequencies $=1(-880.85)$

\begin{tabular}{lrrr}
\multicolumn{4}{l}{ B3LYP/6-31G(d) Geometry } \\
C & -2.55848 & -2.70711 & 1.77459 \\
C & -3.57819 & -3.27659 & 0.91269 \\
C & -2.23375 & -3.21724 & 3.00782 \\
C & -4.18665 & -2.37181 & -0.12712
\end{tabular}




\begin{tabular}{|c|c|c|c|}
\hline $\mathrm{C}$ & -4.48568 & -4.36185 & 1.49240 \\
\hline $\mathrm{C}$ & -3.57013 & -1.16953 & -0.52724 \\
\hline $\mathrm{C}$ & -4.12098 & -0.37139 & -1.52906 \\
\hline $\mathrm{C}$ & -5.30059 & -0.73606 & -2.18993 \\
\hline $\mathrm{C}$ & -5.92115 & -1.92849 & -1.79209 \\
\hline $\mathrm{C}$ & -5.37736 & -2.72816 & -0.79132 \\
\hline $\mathrm{C}$ & -5.87483 & 0.10788 & -3.30320 \\
\hline $\mathrm{N}$ & -1.31750 & -2.75386 & 3.88932 \\
\hline $\mathrm{C}$ & -1.07970 & -3.43954 & 5.15920 \\
\hline $\mathrm{C}$ & -1.02369 & -2.41860 & 6.29934 \\
\hline $\mathrm{O}$ & -0.04627 & -1.42593 & 6.04099 \\
\hline $\mathrm{C}$ & -0.33918 & -0.71930 & 4.83872 \\
\hline $\mathrm{C}$ & -0.37856 & -1.65693 & 3.63132 \\
\hline $\mathrm{H}$ & -2.76642 & -4.08524 & 3.38308 \\
\hline $\mathrm{C}$ & -2.03696 & -4.78654 & -0.70925 \\
\hline $\mathrm{C}$ & -0.75240 & -4.66325 & -0.03215 \\
\hline $\mathrm{C}$ & 0.06685 & -3.61199 & -0.40679 \\
\hline $\mathrm{N}$ & -0.30950 & -2.84207 & -1.47270 \\
\hline $\mathrm{C}$ & -1.34515 & -3.11766 & -2.32947 \\
\hline $\mathrm{C}$ & -2.18421 & -4.17288 & -2.02409 \\
\hline $\mathrm{C}$ & -1.40898 & -2.18186 & -3.50897 \\
\hline $\mathrm{C}$ & 1.36398 & -3.18618 & 0.22566 \\
\hline $\mathrm{C}$ & -3.31316 & -4.70098 & -2.84131 \\
\hline $\mathrm{C}$ & -0.52437 & -5.62560 & 1.07817 \\
\hline $\mathrm{C}$ & -3.50781 & -4.31766 & -4.29832 \\
\hline $\mathrm{O}$ & -4.09503 & -5.49441 & -2.32591 \\
\hline $\mathrm{C}$ & 0.85687 & -5.87142 & 1.66470 \\
\hline $\mathrm{O}$ & -1.47504 & -6.27536 & 1.50740 \\
\hline $\mathrm{C}$ & 3.56283 & 5.00814 & -1.27506 \\
\hline $\mathrm{C}$ & 3.73393 & 3.61997 & -1.01183 \\
\hline $\mathrm{C}$ & 4.90949 & 2.98354 & -1.52179 \\
\hline $\mathrm{C}$ & 5.88137 & 3.75346 & -2.21621 \\
\hline $\mathrm{C}$ & 5.69331 & 5.09816 & -2.43472 \\
\hline $\mathrm{C}$ & 4.51330 & 5.72435 & -1.96877 \\
\hline $\mathrm{C}$ & 2.77232 & 2.82874 & -0.29091 \\
\hline $\mathrm{C}$ & 2.93134 & 1.44931 & -0.25142 \\
\hline $\mathrm{C}$ & 4.10430 & 0.80129 & -0.74640 \\
\hline $\mathrm{C}$ & 5.07257 & 1.58953 & -1.33522 \\
\hline $\mathrm{C}$ & 1.61462 & 3.47557 & 0.38893 \\
\hline $\mathrm{C}$ & 1.81860 & 4.51144 & 1.36531 \\
\hline $\mathrm{C}$ & 0.68575 & 5.24078 & 1.84647 \\
\hline $\mathrm{C}$ & -0.60236 & 4.90653 & 1.36259 \\
\hline $\mathrm{C}$ & -0.82412 & 3.83945 & 0.51431 \\
\hline $\mathrm{C}$ & 0.31438 & 3.09724 & 0.07531 \\
\hline $\mathrm{C}$ & 3.09570 & 4.83179 & 1.90505 \\
\hline $\mathrm{C}$ & 3.24251 & 5.83108 & 2.84180 \\
\hline
\end{tabular}




\begin{tabular}{|c|c|c|c|}
\hline $\mathrm{C}$ & 2.12366 & 6.57404 & 3.28717 \\
\hline $\mathrm{C}$ & 0.87225 & 6.27959 & 2.79820 \\
\hline $\mathrm{C}$ & 4.35669 & -0.67324 & -0.62085 \\
\hline $\mathrm{O}$ & 0.11177 & 2.03517 & -0.78450 \\
\hline $\mathrm{O}$ & 1.96857 & 0.68399 & 0.37848 \\
\hline $\mathrm{C}$ & -2.22793 & 3.56085 & 0.06231 \\
\hline $\mathrm{C}$ & 4.69160 & -1.23184 & 0.63516 \\
\hline $\mathrm{C}$ & 5.06409 & -2.58038 & 0.70056 \\
\hline $\mathrm{C}$ & 5.13367 & -3.39459 & -0.43174 \\
\hline $\mathrm{C}$ & 4.78057 & -2.82632 & -1.65870 \\
\hline $\mathrm{C}$ & 4.38948 & -1.48758 & -1.78119 \\
\hline $\mathrm{C}$ & -3.20464 & 3.15330 & 1.00278 \\
\hline $\mathrm{C}$ & -4.54477 & 3.07405 & 0.60422 \\
\hline $\mathrm{C}$ & -4.95648 & 3.37047 & -0.69519 \\
\hline $\mathrm{C}$ & -3.96864 & 3.72685 & -1.61774 \\
\hline $\mathrm{C}$ & -2.61702 & 3.83665 & -1.27159 \\
\hline$P$ & 0.46515 & 0.48107 & -0.31699 \\
\hline $\mathrm{O}$ & -0.43710 & -0.01423 & 0.77350 \\
\hline $\mathrm{O}$ & 0.61044 & -0.28995 & -1.61148 \\
\hline $\mathrm{C}$ & -1.62935 & 4.30293 & -2.34117 \\
\hline $\mathrm{C}$ & -1.97247 & 5.71669 & -2.85141 \\
\hline $\mathrm{C}$ & -1.52906 & 3.29863 & -3.50484 \\
\hline $\mathrm{C}$ & -6.42483 & 3.38593 & -1.10609 \\
\hline $\mathrm{C}$ & -7.03520 & & -0.86536 \\
\hline $\mathrm{C}$ & -7.27669 & 2.30115 & -0.42749 \\
\hline $\mathrm{C}$ & -2.86296 & 2.78287 & 2.44679 \\
\hline $\mathrm{C}$ & -3.22419 & 1.31649 & 2.74786 \\
\hline $\mathrm{C}$ & -3.52767 & 3.73499 & 3.45993 \\
\hline $\mathrm{C}$ & 5.63936 & -4.82893 & -0.32638 \\
\hline $\mathrm{C}$ & 7.04970 & -4.96290 & -0.93503 \\
\hline $\mathrm{C}$ & 4.67951 & -5.85720 & -0.95048 \\
\hline $\mathrm{C}$ & 4.03896 & -0.95758 & -3.17342 \\
\hline $\mathrm{C}$ & 2.89179 & -1.75038 & -3.82642 \\
\hline $\mathrm{C}$ & 5.27534 & -0.92914 & -4.09396 \\
\hline $\mathrm{C}$ & 4.71846 & -0.40398 & 1.91975 \\
\hline $\mathrm{C}$ & 6.13782 & -0.33226 & 2.51662 \\
\hline $\mathrm{C}$ & 3.70299 & -0.91912 & 2.95663 \\
\hline $\mathrm{H}$ & -2.00705 & -1.84879 & 1.41173 \\
\hline $\mathrm{H}$ & -4.99286 & -4.91674 & 0.70155 \\
\hline $\mathrm{H}$ & -5.24550 & -3.92211 & 2.15037 \\
\hline $\mathrm{H}$ & -3.90528 & -5.09675 & 2.05251 \\
\hline $\mathrm{H}$ & -2.64745 & -0.82703 & -0.07117 \\
\hline $\mathrm{H}$ & -3.62059 & 0.55663 & -1.79282 \\
\hline $\mathrm{H}$ & -6.84422 & -2.24219 & -2.27515 \\
\hline $\mathrm{H}$ & -5.89361 & -3.64601 & -0.53866 \\
\hline $\mathrm{H}$ & -6.94574 & 0.29091 & -3.15669 \\
\hline
\end{tabular}




\begin{tabular}{|c|c|c|c|}
\hline $\mathrm{H}$ & -5.37049 & 1.07647 & -3.36707 \\
\hline $\mathrm{H}$ & -5.76655 & -0.38855 & -4.27679 \\
\hline $\mathrm{H}$ & -0.12079 & -3.97792 & 5.11495 \\
\hline $\mathrm{H}$ & -1.87586 & -4.16954 & 5.33299 \\
\hline $\mathrm{H}$ & -2.01705 & -1.95765 & 6.43017 \\
\hline $\mathrm{H}$ & -0.73762 & -2.90890 & 7.23489 \\
\hline $\mathrm{H}$ & -1.30279 & -0.19520 & 4.93550 \\
\hline $\mathrm{H}$ & 0.45315 & 0.02216 & 4.71003 \\
\hline $\mathrm{H}$ & 0.62494 & -2.08403 & 3.48455 \\
\hline $\mathrm{H}$ & -0.64004 & -1.10524 & 2.72696 \\
\hline $\mathrm{H}$ & -2.85146 & -4.07799 & 0.07175 \\
\hline $\mathrm{H}$ & -2.54325 & -5.74108 & -0.58510 \\
\hline $\mathrm{H}$ & 0.15593 & -1.90774 & -1.57637 \\
\hline $\mathrm{H}$ & -2.43736 & -1.92513 & -3.76196 \\
\hline $\mathrm{H}$ & -0.87113 & -1.25963 & -3.27302 \\
\hline $\mathrm{H}$ & -0.93658 & -2.62897 & -4.39229 \\
\hline $\mathrm{H}$ & 1.27186 & -3.09954 & 1.30935 \\
\hline $\mathrm{H}$ & 2.16330 & -3.90126 & 0.00869 \\
\hline $\mathrm{H}$ & 1.68480 & -2.22045 & -0.16482 \\
\hline $\mathrm{H}$ & -4.16199 & -5.06464 & -4.75279 \\
\hline $\mathrm{H}$ & -4.00461 & -3.34247 & -4.36852 \\
\hline $\mathrm{H}$ & -2.56905 & -4.25811 & -4.85574 \\
\hline $\mathrm{H}$ & 1.15755 & -5.05401 & 2.32926 \\
\hline $\mathrm{H}$ & 1.62582 & -5.96468 & 0.89156 \\
\hline $\mathrm{H}$ & 0.80950 & -6.79240 & 2.24936 \\
\hline $\mathrm{H}$ & 2.66173 & 5.50407 & -0.93432 \\
\hline $\mathrm{H}$ & 6.77303 & 3.25169 & -2.58514 \\
\hline $\mathrm{H}$ & 6.43854 & 5.67685 & -2.97373 \\
\hline $\mathrm{H}$ & 4.35199 & 6.78118 & -2.16417 \\
\hline $\mathrm{H}$ & 5.98689 & 1.12191 & -1.69143 \\
\hline $\mathrm{H}$ & -1.45036 & 5.50349 & 1.68833 \\
\hline $\mathrm{H}$ & 3.96258 & 4.26751 & 1.58114 \\
\hline $\mathrm{H}$ & 4.22778 & 6.04804 & 3.24593 \\
\hline $\mathrm{H}$ & 2.25462 & 7.36496 & 4.02071 \\
\hline $\mathrm{H}$ & -0.00049 & 6.82957 & 3.14284 \\
\hline $\mathrm{H}$ & 5.33944 & -3.00410 & 1.66450 \\
\hline $\mathrm{H}$ & 4.82510 & -3.43732 & -2.55699 \\
\hline $\mathrm{H}$ & -5.28538 & 2.77339 & 1.33943 \\
\hline $\mathrm{H}$ & -4.26943 & 3.95873 & -2.63801 \\
\hline $\mathrm{H}$ & -0.63710 & 4.36468 & -1.88798 \\
\hline $\mathrm{H}$ & -2.00932 & 6.43758 & -2.02686 \\
\hline $\mathrm{H}$ & -1.21514 & 6.05769 & -3.56768 \\
\hline $\mathrm{H}$ & -2.94387 & 5.74107 & -3.35944 \\
\hline $\mathrm{H}$ & -0.79273 & 3.64214 & -4.24167 \\
\hline $\mathrm{H}$ & -2.48931 & 3.18654 & -4.02384 \\
\hline $\mathrm{H}$ & -1.21164 & 2.31664 & -3.14182 \\
\hline
\end{tabular}




$\begin{array}{lrrr}\mathrm{H} & -6.45659 & 3.20053 & -2.18929 \\ \mathrm{H} & -6.47034 & 5.55932 & -1.39238 \\ \mathrm{H} & -8.07539 & 4.82021 & -1.21221 \\ \mathrm{H} & -7.02498 & 5.03012 & 0.20310 \\ \mathrm{H} & -6.83708 & 1.30610 & -0.55165 \\ \mathrm{H} & -7.38718 & 2.48751 & 0.64734 \\ \mathrm{H} & -8.28559 & 2.28874 & -0.85673 \\ \mathrm{H} & -1.78126 & 2.87289 & 2.57411 \\ \mathrm{H} & -2.67208 & 0.64647 & 2.08340 \\ \mathrm{H} & -2.96438 & 1.06955 & 3.78548 \\ \mathrm{H} & -4.29602 & 1.12334 & 2.62239 \\ \mathrm{H} & -4.62162 & 3.67605 & 3.41176 \\ \mathrm{H} & -3.24506 & 4.77797 & 3.27770 \\ \mathrm{H} & -3.22641 & 3.47736 & 4.48271 \\ \mathrm{H} & 5.72126 & -5.06385 & 0.74403 \\ \mathrm{H} & 7.75024 & -4.26522 & -0.46374 \\ \mathrm{H} & 7.03603 & -4.74620 & -2.00986 \\ \mathrm{H} & 7.43709 & -5.98037 & -0.80168 \\ \mathrm{H} & 4.55873 & -5.69586 & -2.02791 \\ \mathrm{H} & 5.06109 & -6.87548 & -0.81037 \\ \mathrm{H} & 3.68473 & -5.80531 & -0.49257 \\ \mathrm{H} & 3.68432 & 0.07010 & -3.06431 \\ \mathrm{H} & 1.99080 & -1.68385 & -3.21226 \\ \mathrm{H} & 2.66080 & -1.33055 & -4.81315 \\ \mathrm{H} & 3.14923 & -2.80708 & -3.96889 \\ \mathrm{H} & 6.08498 & -0.32891 & -3.66441 \\ \mathrm{H} & 5.66877 & -1.93805 & -4.26850 \\ \mathrm{H} & 5.01669 & -0.49905 & -5.06905 \\ \mathrm{H} & 4.42734 & 0.61955 & 1.67098 \\ \mathrm{H} & 6.85209 & 0.07122 & 1.79025 \\ \mathrm{H} & 6.14811 & 0.31712 & 3.40030 \\ \mathrm{H} & 6.49873 & -1.32025 & 2.82628 \\ \mathrm{H} & 2.68981 & -0.89097 & 2.54371 \\ \mathrm{H} & 3.92740 & -1.94752 & 3.26631 \\ & 3.72322 & -0.29139 & 3.85581\end{array}$

TS6-Z

B3LYP/6-31G(d) Energy = -3928.459926

B3LYP/6-31G(d) Free Energy = -3927.083576

B3LYP/6-311+G(d,p) Derived free energy $=-3928.034595$

B3LYP/6-311+G(d,p) Derived free energy in solution $=-3928.046230$

Number of Imaginary Frequencies $=1(-966.30)$

\begin{tabular}{|c|c|c|c|}
\hline & $6-31 G(d$ & eometry & \\
\hline $\mathrm{C}$ & 3.94290 & 0.11076 & 1.25596 \\
\hline $\mathrm{C}$ & 5.00088 & -0.49911 & 0.49993 \\
\hline
\end{tabular}




\begin{tabular}{|c|c|c|c|}
\hline $\mathrm{C}$ & 4.00217 & 1.38565 & 1.78642 \\
\hline $\mathrm{C}$ & 6.44863 & -0.17920 & 0.77431 \\
\hline $\mathrm{C}$ & 4.75500 & -1.95622 & 0.11669 \\
\hline $\mathrm{C}$ & 7.41671 & -0.32993 & -0.23715 \\
\hline $\mathrm{C}$ & 8.76456 & -0.10324 & 0.02467 \\
\hline $\mathrm{C}$ & 9.20992 & 0.26839 & 1.30235 \\
\hline $\mathrm{C}$ & 8.25071 & 0.39086 & 2.31266 \\
\hline $\mathrm{C}$ & 6.89635 & 0.17235 & 2.05774 \\
\hline $\mathrm{C}$ & 10.67224 & 0.53365 & 1.56916 \\
\hline $\mathrm{N}$ & 3.05098 & 2.03393 & 2.48183 \\
\hline $\mathrm{C}$ & 3.38821 & 3.29296 & 3.16195 \\
\hline $\mathrm{C}$ & 2.16041 & 4.19662 & 3.26184 \\
\hline $\mathrm{O}$ & 1.08577 & 3.51772 & 3.88623 \\
\hline $\mathrm{C}$ & 0.68944 & 2.39627 & 3.10327 \\
\hline $\mathrm{C}$ & 1.81504 & 1.37744 & 2.93919 \\
\hline $\mathrm{H}$ & 4.91282 & 1.96365 & 1.65735 \\
\hline $\mathrm{C}$ & 4.54028 & 0.69893 & -1.91006 \\
\hline $\mathrm{C}$ & 3.82515 & 1.89350 & -1.47347 \\
\hline $\mathrm{C}$ & 2.43642 & 1.84545 & -1.44671 \\
\hline $\mathrm{N}$ & 1.80635 & 0.75206 & -1.96069 \\
\hline $\mathrm{C}$ & 2.41682 & -0.27379 & -2.63588 \\
\hline $\mathrm{C}$ & 3.79740 & -0.28835 & -2.70705 \\
\hline $\mathrm{C}$ & 1.44448 & -1.26659 & -3.22404 \\
\hline $\mathrm{C}$ & 1.52417 & 2.92369 & -0.94073 \\
\hline $\mathrm{C}$ & 4.64699 & -1.25604 & -3.44370 \\
\hline $\mathrm{C}$ & 4.56731 & 3.10295 & -1.03275 \\
\hline $\mathrm{C}$ & 4.08891 & -2.21048 & -4.48456 \\
\hline $\mathrm{O}$ & 5.85974 & -1.26637 & -3.22542 \\
\hline $\mathrm{C}$ & 6.04343 & 3.21251 & -1.39229 \\
\hline $\mathrm{O}$ & 4.03057 & 4.01223 & -0.40314 \\
\hline $\mathrm{C}$ & -6.53961 & -1.57836 & -0.79339 \\
\hline $\mathrm{C}$ & -5.74165 & -0.40757 & -0.66003 \\
\hline $\mathrm{C}$ & -6.22377 & 0.80076 & -1.25868 \\
\hline $\mathrm{C}$ & -7.48797 & 0.80675 & -1.90729 \\
\hline $\mathrm{C}$ & -8.24353 & -0.33908 & -1.99768 \\
\hline $\mathrm{C}$ & -7.75322 & -1.54503 & -1.44468 \\
\hline $\mathrm{C}$ & -4.46814 & -0.39247 & 0.01141 \\
\hline $\mathrm{C}$ & -3.68686 & 0.75239 & -0.07270 \\
\hline $\mathrm{C}$ & -4.15569 & 1.96716 & -0.66015 \\
\hline $\mathrm{C}$ & -5.42043 & 1.96762 & -1.20894 \\
\hline $\mathrm{C}$ & -3.97194 & -1.59079 & 0.74893 \\
\hline $\mathrm{C}$ & -4.74004 & -2.19706 & 1.80317 \\
\hline $\mathrm{C}$ & -4.30632 & -3.44864 & 2.34753 \\
\hline $\mathrm{C}$ & -3.12653 & -4.05112 & 1.84218 \\
\hline $\mathrm{C}$ & -2.32681 & -3.42853 & 0.90656 \\
\hline $\mathrm{C}$ & -2.74817 & -2.15688 & 0.41244 \\
\hline
\end{tabular}




\begin{tabular}{|c|c|c|c|}
\hline $\mathrm{C}$ & -5.90107 & -1.59366 & 2.36165 \\
\hline $\mathrm{C}$ & -6.60395 & -2.20496 & 3.37661 \\
\hline $\mathrm{C}$ & -6.19161 & -3.45828 & 3.88702 \\
\hline $\mathrm{C}$ & -5.06393 & -4.06238 & 3.38110 \\
\hline $\mathrm{C}$ & -3.32546 & 3.21736 & -0.65001 \\
\hline $\mathrm{O}$ & -1.94561 & -1.53139 & -0.51801 \\
\hline $\mathrm{O}$ & -2.43902 & 0.75769 & 0.51834 \\
\hline $\mathrm{C}$ & -1.09624 & -4.11257 & 0.38630 \\
\hline $\mathrm{C}$ & -3.19825 & 3.96322 & 0.54674 \\
\hline $\mathrm{C}$ & -2.42866 & 5.13061 & 0.54132 \\
\hline $\mathrm{C}$ & -1.79866 & 5.60142 & -0.61435 \\
\hline $\mathrm{C}$ & -1.96300 & 4.86456 & -1.78798 \\
\hline $\mathrm{C}$ & -2.71153 & 3.68077 & -1.83727 \\
\hline $\mathrm{C}$ & 0.04224 & -4.27149 & 1.21262 \\
\hline $\mathrm{C}$ & 1.14076 & -4.98830 & 0.72364 \\
\hline $\mathrm{C}$ & 1.15752 & -5.55002 & -0.55554 \\
\hline $\mathrm{C}$ & 0.02879 & -5.36842 & -1.35595 \\
\hline $\mathrm{C}$ & -1.10044 & -4.66861 & -0.91472 \\
\hline $\mathrm{P}$ & -1.18183 & -0.09917 & -0.14597 \\
\hline $\mathrm{O}$ & -0.14631 & -0.24308 & 0.92330 \\
\hline $\mathrm{O}$ & -0.81619 & 0.46834 & -1.50407 \\
\hline $\mathrm{C}$ & -2.31027 & -4.58016 & -1.84500 \\
\hline $\mathrm{C}$ & -2.89798 & -5.97563 & -2.13501 \\
\hline $\mathrm{C}$ & -1.98333 & -3.83094 & -3.15014 \\
\hline $\mathrm{C}$ & 2.34474 & -6.36096 & -1.06018 \\
\hline $\mathrm{C}$ & 2.54508 & -7.64849 & -0.23777 \\
\hline $\mathrm{C}$ & 3.64260 & -5.53413 & -1.10650 \\
\hline $\mathrm{C}$ & 0.11842 & -3.69471 & 2.62640 \\
\hline $\mathrm{C}$ & 1.29739 & -2.71687 & 2.78064 \\
\hline $\mathrm{C}$ & 0.17355 & -4.80758 & 3.69093 \\
\hline $\mathrm{C}$ & -0.99017 & 6.89304 & -0.61267 \\
\hline $\mathrm{C}$ & 0.21038 & 6.83017 & 0.35012 \\
\hline $\mathrm{C}$ & -1.87452 & 8.11737 & -0.30706 \\
\hline $\mathrm{C}$ & -2.88484 & 2.97424 & -3.18319 \\
\hline $\mathrm{C}$ & -1.55377 & 2.70866 & -3.90845 \\
\hline $\mathrm{C}$ & -3.84618 & 3.76753 & -4.09249 \\
\hline $\mathrm{C}$ & -3.92175 & 3.56652 & 1.83435 \\
\hline $\mathrm{C}$ & -4.90907 & 4.66184 & 2.28389 \\
\hline $\mathrm{C}$ & -2.94332 & 3.19979 & 2.96458 \\
\hline $\mathrm{H}$ & 3.00798 & -0.43830 & 1.30873 \\
\hline $\mathrm{H}$ & 4.92279 & -2.59196 & 0.99541 \\
\hline $\mathrm{H}$ & 5.43723 & -2.28591 & -0.66971 \\
\hline $\mathrm{H}$ & 3.72407 & -2.11125 & -0.21599 \\
\hline $\mathrm{H}$ & 7.11094 & -0.62936 & -1.23649 \\
\hline $\mathrm{H}$ & 9.48728 & -0.22336 & -0.77947 \\
\hline $\mathrm{H}$ & 8.56500 & 0.65186 & 3.32076 \\
\hline
\end{tabular}




\begin{tabular}{|c|c|c|c|}
\hline $\mathrm{H}$ & 6.18396 & 0.24063 & 2.87349 \\
\hline $\mathrm{H}$ & 11.31089 & -0.20088 & 1.06596 \\
\hline $\mathrm{H}$ & 10.96957 & 1.52453 & 1.20084 \\
\hline $\mathrm{H}$ & 10.89693 & 0.50124 & 2.63996 \\
\hline $\mathrm{H}$ & 4.18187 & 3.79288 & 2.59994 \\
\hline $\mathrm{H}$ & 3.75154 & 3.07176 & 4.17697 \\
\hline $\mathrm{H}$ & 2.39300 & 5.06847 & 3.88057 \\
\hline $\mathrm{H}$ & 1.86986 & 4.54580 & 2.25840 \\
\hline $\mathrm{H}$ & -0.14902 & 1.92620 & 3.61977 \\
\hline $\mathrm{H}$ & 0.33767 & 2.72894 & 2.11633 \\
\hline $\mathrm{H}$ & 1.48200 & 0.63538 & 2.21163 \\
\hline $\mathrm{H}$ & 2.01811 & 0.87901 & 3.89848 \\
\hline $\mathrm{H}$ & 4.83840 & 0.08388 & -0.78581 \\
\hline $\mathrm{H}$ & 5.56034 & 0.84277 & -2.26025 \\
\hline $\mathrm{H}$ & 0.76358 & 0.67778 & -1.80428 \\
\hline $\mathrm{H}$ & 1.70878 & -2.29367 & -2.96124 \\
\hline $\mathrm{H}$ & 0.43833 & -1.06699 & -2.84868 \\
\hline $\mathrm{H}$ & 1.41705 & -1.19483 & -4.31665 \\
\hline $\mathrm{H}$ & 1.70164 & 3.09627 & 0.12321 \\
\hline $\mathrm{H}$ & 1.74282 & 3.87271 & -1.43847 \\
\hline $\mathrm{H}$ & 0.47867 & 2.65523 & -1.09941 \\
\hline $\mathrm{H}$ & 4.93395 & -2.64354 & -5.02312 \\
\hline $\mathrm{H}$ & 3.52397 & -3.02336 & -4.01449 \\
\hline $\mathrm{H}$ & 3.41933 & -1.71033 & -5.19085 \\
\hline $\mathrm{H}$ & 6.20165 & 3.09571 & -2.47125 \\
\hline $\mathrm{H}$ & 6.64049 & 2.44069 & -0.89288 \\
\hline $\mathrm{H}$ & 6.39739 & 4.19629 & -1.07885 \\
\hline $\mathrm{H}$ & -6.17757 & -2.51423 & -0.38462 \\
\hline $\mathrm{H}$ & -7.84041 & 1.73798 & -2.34502 \\
\hline $\mathrm{H}$ & -9.20583 & -0.32446 & -2.50230 \\
\hline $\mathrm{H}$ & -8.33721 & -2.45685 & -1.53833 \\
\hline $\mathrm{H}$ & -5.81197 & 2.88691 & -1.63705 \\
\hline $\mathrm{H}$ & -2.83876 & -5.02985 & 2.21840 \\
\hline $\mathrm{H}$ & -6.22485 & -0.62908 & 1.98788 \\
\hline $\mathrm{H}$ & -7.48132 & -1.71667 & 3.79249 \\
\hline $\mathrm{H}$ & -6.75876 & -3.93332 & 4.68298 \\
\hline $\mathrm{H}$ & -4.72463 & -5.01804 & 3.77435 \\
\hline $\mathrm{H}$ & -2.33493 & 5.69736 & 1.46480 \\
\hline $\mathrm{H}$ & -1.49778 & 5.23147 & -2.70038 \\
\hline $\mathrm{H}$ & 2.00635 & -5.11698 & 1.36945 \\
\hline $\mathrm{H}$ & 0.01997 & -5.80765 & -2.35167 \\
\hline $\mathrm{H}$ & -3.09085 & -4.00818 & -1.33710 \\
\hline $\mathrm{H}$ & -3.16970 & -6.49135 & -1.20710 \\
\hline $\mathrm{H}$ & -3.79991 & -5.88975 & -2.75312 \\
\hline $\mathrm{H}$ & -2.18508 & -6.61153 & -2.67345 \\
\hline $\mathrm{H}$ & -1.63303 & -2.81725 & -2.93435 \\
\hline
\end{tabular}




$\begin{array}{lrrr}\mathrm{H} & -1.21239 & -4.35070 & -3.73265 \\ \mathrm{H} & -2.87806 & -3.75456 & -3.77986 \\ \mathrm{H} & 2.11274 & -6.66395 & -2.09072 \\ \mathrm{H} & 1.63693 & -8.26082 & -0.23728 \\ \mathrm{H} & 3.36410 & -8.25049 & -0.65008 \\ \mathrm{H} & 2.79187 & -7.41815 & 0.80546 \\ \mathrm{H} & 3.51842 & -4.63644 & -1.72349 \\ \mathrm{H} & 3.94457 & -5.20885 & -0.10393 \\ \mathrm{H} & 4.46624 & -6.12401 & -1.52651 \\ \mathrm{H} & -0.79116 & -3.11510 & 2.80309 \\ \mathrm{H} & 1.19118 & -1.89917 & 2.06251 \\ \mathrm{H} & 1.30451 & -2.29079 & 3.79205 \\ \mathrm{H} & 2.26388 & -3.21262 & 2.62504 \\ \mathrm{H} & -0.69056 & -5.47763 & 3.61664 \\ \mathrm{H} & 1.07689 & -5.42077 & 3.58526 \\ \mathrm{H} & 0.18052 & -4.37484 & 4.69880 \\ \mathrm{H} & -0.58966 & 7.02395 & -1.62758 \\ \mathrm{H} & 0.87721 & 5.99743 & 0.09956 \\ \mathrm{H} & -0.11841 & 6.69722 & 1.38780 \\ \mathrm{H} & 0.79437 & 7.75741 & 0.30240 \\ \mathrm{H} & -2.29740 & 8.05930 & 0.70292 \\ \mathrm{H} & -1.29129 & 9.04413 & -0.37202 \\ \mathrm{H} & -2.70880 & 8.18790 & -1.01348 \\ \mathrm{H} & -3.33725 & 1.99728 & -2.99378 \\ \mathrm{H} & -0.91002 & 2.07568 & -3.29417 \\ \mathrm{H} & -1.74475 & 2.18570 & -4.85392 \\ \mathrm{H} & -1.02103 & 3.63607 & -4.15175 \\ \mathrm{H} & -4.82027 & 3.92085 & -3.61517 \\ \mathrm{H} & -3.43710 & 4.75662 & -4.33303 \\ \mathrm{H} & -4.01183 & 3.23406 & -5.03660 \\ \mathrm{H} & -4.51692 & 2.67309 & 1.62518 \\ \mathrm{H} & -5.62605 & 4.89998 & 1.49008 \\ \mathrm{H} & -5.47311 & 4.32875 & 3.16361 \\ \mathrm{H} & -4.39124 & 5.58958 & 2.55462 \\ \mathrm{H} & -2.31991 & 2.35310 & 2.66508 \\ \mathrm{H} & -2.28589 & 4.03889 & 3.22326 \\ & -3.49420 & 2.91711 & 3.87028\end{array}$

\section{TS7-E}

B3LYP/6-31G(d) Energy $=-3928.457522$

B3LYP/6-31G(d) Free Energy $=-3927.079540$

B3LYP/6-311+G(d,p) Derived free energy $=-3928.027956$

B3LYP/6-311+G(d,p) Derived free energy in solution $=-3928.038811$

Number of Imaginary Frequencies $=1(-1017.75)$

B3LYP/6-31G(d) Geometry 


\begin{tabular}{|c|c|c|c|}
\hline $\mathrm{C}$ & -4.59063 & 0.27540 & -0.08433 \\
\hline $\mathrm{C}$ & -4.67185 & -0.63652 & 1.02368 \\
\hline $\mathrm{C}$ & -3.42068 & 0.82353 & -0.57614 \\
\hline $\mathrm{C}$ & -6.05074 & -0.83125 & 1.60769 \\
\hline $\mathrm{C}$ & -3.55066 & -0.68350 & 2.05871 \\
\hline $\mathrm{C}$ & -6.98198 & 0.22032 & 1.61060 \\
\hline $\mathrm{C}$ & -8.23684 & 0.06881 & 2.19971 \\
\hline $\mathrm{C}$ & -8.61562 & -1.13630 & 2.80093 \\
\hline $\mathrm{C}$ & -7.68295 & -2.18308 & 2.80216 \\
\hline $\mathrm{C}$ & -6.42498 & -2.03822 & 2.22343 \\
\hline $\mathrm{C}$ & -9.98568 & -1.31337 & 3.41118 \\
\hline $\mathrm{N}$ & -3.30286 & 1.63335 & -1.64659 \\
\hline $\mathrm{C}$ & -4.47082 & 2.14369 & -2.37193 \\
\hline $\mathrm{C}$ & -4.11092 & 2.48057 & -3.82016 \\
\hline $\mathrm{O}$ & -2.97435 & 3.32258 & -3.89963 \\
\hline $\mathrm{C}$ & -1.83685 & 2.66403 & -3.34899 \\
\hline $\mathrm{C}$ & -2.03822 & 2.36102 & -1.86814 \\
\hline $\mathrm{H}$ & -2.47116 & 0.61827 & -0.08392 \\
\hline $\mathrm{C}$ & -3.99847 & -2.92675 & -0.30179 \\
\hline $\mathrm{C}$ & -2.82638 & -3.46979 & 0.39557 \\
\hline $\mathrm{C}$ & -1.57529 & -3.02750 & 0.00766 \\
\hline $\mathrm{N}$ & -1.47707 & -2.25304 & -1.12078 \\
\hline $\mathrm{C}$ & -2.50032 & -1.97775 & -1.97983 \\
\hline $\mathrm{C}$ & -3.78956 & -2.35675 & -1.62910 \\
\hline $\mathrm{C}$ & -2.07886 & -1.31151 & -3.25718 \\
\hline $\mathrm{C}$ & -0.25903 & -3.28084 & 0.68531 \\
\hline $\mathrm{C}$ & -4.94682 & -2.10457 & -2.52760 \\
\hline $\mathrm{C}$ & -3.13242 & -4.38907 & 1.52093 \\
\hline $\mathrm{C}$ & -6.31565 & -2.60353 & -2.08604 \\
\hline $\mathrm{O}$ & -4.83305 & -1.51980 & -3.60217 \\
\hline $\mathrm{C}$ & -2.06671 & -5.18663 & 2.25162 \\
\hline $\mathrm{O}$ & -4.30708 & -4.53728 & 1.86044 \\
\hline $\mathrm{C}$ & 6.24922 & 1.79053 & -0.33880 \\
\hline $\mathrm{C}$ & 5.51487 & 0.57537 & -0.23993 \\
\hline $\mathrm{C}$ & 6.11460 & -0.61266 & -0.76414 \\
\hline $\mathrm{C}$ & 7.42272 & -0.55586 & -1.31605 \\
\hline $\mathrm{C}$ & 8.11137 & 0.63295 & -1.38014 \\
\hline $\mathrm{C}$ & 7.50887 & 1.81790 & -0.89572 \\
\hline $\mathrm{C}$ & 4.19683 & 0.49441 & 0.32997 \\
\hline $\mathrm{C}$ & 3.48235 & -0.69066 & 0.21910 \\
\hline $\mathrm{C}$ & 4.08098 & -1.89198 & -0.27198 \\
\hline $\mathrm{C}$ & 5.38353 & -1.82454 & -0.72375 \\
\hline $\mathrm{C}$ & 3.59756 & 1.67051 & 1.01834 \\
\hline $\mathrm{C}$ & 4.26067 & 2.28290 & 2.13708 \\
\hline $\mathrm{C}$ & 3.75681 & 3.52047 & 2.64701 \\
\hline $\mathrm{C}$ & 2.62464 & 4.10402 & 2.02869 \\
\hline
\end{tabular}




\begin{tabular}{|c|c|c|c|}
\hline $\mathrm{C}$ & 1.92292 & 3.47615 & 1.01862 \\
\hline $\mathrm{C}$ & 2.39573 & 2.20464 & 0.57047 \\
\hline $\mathrm{C}$ & 5.38293 & 1.70000 & 2.78934 \\
\hline $\mathrm{C}$ & 5.97979 & 2.31797 & 3.86612 \\
\hline $\mathrm{C}$ & 5.49596 & 3.55750 & 4.34748 \\
\hline $\mathrm{C}$ & 4.40504 & 4.14254 & 3.74781 \\
\hline $\mathrm{C}$ & 3.39946 & -3.22975 & -0.25535 \\
\hline $\mathrm{O}$ & 1.69321 & 1.54214 & -0.42129 \\
\hline $\mathrm{O}$ & 2.18736 & -0.73453 & 0.69998 \\
\hline $\mathrm{C}$ & 0.77726 & 4.21115 & 0.38607 \\
\hline $\mathrm{C}$ & 3.31057 & -3.95480 & 0.95578 \\
\hline $\mathrm{C}$ & 2.79115 & -5.25562 & 0.92932 \\
\hline $\mathrm{C}$ & 2.37068 & -5.86951 & -0.25238 \\
\hline $\mathrm{C}$ & 2.46354 & -5.13077 & -1.43550 \\
\hline $\mathrm{C}$ & 2.96552 & -3.82449 & -1.46621 \\
\hline $\mathrm{C}$ & -0.41535 & 4.44424 & 1.11327 \\
\hline $\mathrm{C}$ & -1.39247 & 5.28355 & 0.56211 \\
\hline $\mathrm{C}$ & -1.23023 & 5.90861 & -0.67852 \\
\hline $\mathrm{C}$ & -0.05691 & 5.64046 & -1.38702 \\
\hline $\mathrm{C}$ & 0.95363 & 4.81135 & -0.88400 \\
\hline $\mathrm{P}$ & 0.95521 & 0.08224 & -0.08350 \\
\hline $\mathrm{O}$ & -0.16902 & 0.23055 & 0.89561 \\
\hline $\mathrm{O}$ & 0.70121 & -0.56678 & -1.42808 \\
\hline $\mathrm{C}$ & 2.23690 & 4.64878 & -1.70000 \\
\hline $\mathrm{C}$ & 2.95091 & 5.99957 & -1.90508 \\
\hline $\mathrm{C}$ & 1.98364 & 3.94300 & -3.04502 \\
\hline $\mathrm{C}$ & -2.26667 & 6.88027 & -1.23212 \\
\hline $\mathrm{C}$ & -2.46933 & 8.08756 & -0.29680 \\
\hline $\mathrm{C}$ & -3.60901 & 6.19422 & -1.54793 \\
\hline $\mathrm{C}$ & -0.66865 & 3.83302 & 2.49240 \\
\hline $\mathrm{C}$ & -1.87317 & 2.87397 & 2.48132 \\
\hline $\mathrm{C}$ & -0.82897 & 4.91713 & 3.57594 \\
\hline $\mathrm{C}$ & 1.87746 & -7.31182 & -0.24640 \\
\hline $\mathrm{C}$ & 2.89693 & -8.25206 & -0.91948 \\
\hline $\mathrm{C}$ & 0.48610 & -7.47120 & -0.88542 \\
\hline $\mathrm{C}$ & 3.06867 & -3.10587 & -2.81299 \\
\hline $\mathrm{C}$ & 1.73820 & -3.09748 & -3.58614 \\
\hline $\mathrm{C}$ & 4.19138 & -3.71000 & -3.68064 \\
\hline $\mathrm{C}$ & 3.80886 & -3.38927 & 2.28603 \\
\hline $\mathrm{C}$ & 4.96050 & -4.23617 & 2.86262 \\
\hline $\mathrm{C}$ & 2.67062 & -3.22594 & 3.31061 \\
\hline $\mathrm{H}$ & -5.52250 & 0.47901 & -0.60019 \\
\hline $\mathrm{H}$ & -3.62737 & -1.59100 & 2.66484 \\
\hline $\mathrm{H}$ & -3.66334 & 0.17128 & 2.73649 \\
\hline $\mathrm{H}$ & -2.54828 & -0.63351 & 1.62533 \\
\hline $\mathrm{H}$ & -6.71116 & 1.17942 & 1.17952 \\
\hline
\end{tabular}




\begin{tabular}{|c|c|c|c|}
\hline $\mathrm{H}$ & -8.92938 & 0.90769 & 2.19715 \\
\hline $\mathrm{H}$ & -7.94500 & -3.13278 & 3.26358 \\
\hline $\mathrm{H}$ & -5.73771 & -2.87927 & 2.23307 \\
\hline $\mathrm{H}$ & -10.45382 & -0.34885 & 3.63284 \\
\hline $\mathrm{H}$ & -9.93838 & -1.88937 & 4.34207 \\
\hline $\mathrm{H}$ & -10.65683 & -1.85500 & 2.73120 \\
\hline $\mathrm{H}$ & -4.85565 & 3.03814 & -1.86081 \\
\hline $\mathrm{H}$ & -5.25257 & 1.38162 & -2.37799 \\
\hline $\mathrm{H}$ & -4.94063 & 3.01858 & -4.28740 \\
\hline $\mathrm{H}$ & -3.93785 & 1.55030 & -4.38421 \\
\hline $\mathrm{H}$ & -1.63403 & 1.74012 & -3.91188 \\
\hline $\mathrm{H}$ & -0.98929 & 3.34106 & -3.46882 \\
\hline $\mathrm{H}$ & -2.05849 & 3.30124 & -1.30485 \\
\hline $\mathrm{H}$ & -1.21368 & 1.75238 & -1.49050 \\
\hline $\mathrm{H}$ & -4.41828 & -1.88046 & 0.41377 \\
\hline $\mathrm{H}$ & -4.89330 & -3.52956 & -0.15894 \\
\hline $\mathrm{H}$ & -0.57534 & -1.74866 & -1.28774 \\
\hline $\mathrm{H}$ & -2.72698 & -0.46623 & -3.48231 \\
\hline $\mathrm{H}$ & -1.03845 & -0.98554 & -3.18802 \\
\hline $\mathrm{H}$ & -2.18787 & -2.00819 & -4.09603 \\
\hline $\mathrm{H}$ & -0.02592 & -4.34539 & 0.74022 \\
\hline $\mathrm{H}$ & 0.55327 & -2.80266 & 0.14054 \\
\hline $\mathrm{H}$ & -0.25950 & -2.87380 & 1.70015 \\
\hline $\mathrm{H}$ & -7.04434 & -2.31987 & -2.84737 \\
\hline $\mathrm{H}$ & -6.31916 & -3.69533 & -1.97637 \\
\hline $\mathrm{H}$ & -6.61497 & -2.18267 & -1.11938 \\
\hline $\mathrm{H}$ & -2.57761 & -5.85605 & 2.94609 \\
\hline $\mathrm{H}$ & -1.39024 & -4.53730 & 2.81645 \\
\hline $\mathrm{H}$ & -1.45453 & -5.77780 & 1.56230 \\
\hline $\mathrm{H}$ & 5.80171 & 2.71006 & 0.01967 \\
\hline $\mathrm{H}$ & 7.86405 & -1.47303 & -1.69941 \\
\hline $\mathrm{H}$ & 9.10845 & 0.66783 & -1.81068 \\
\hline $\mathrm{H}$ & 8.04363 & 2.76129 & -0.96752 \\
\hline $\mathrm{H}$ & 5.86636 & -2.73349 & -1.07316 \\
\hline $\mathrm{H}$ & 2.29287 & 5.08197 & 2.36864 \\
\hline $\mathrm{H}$ & 5.76107 & 0.74647 & 2.43902 \\
\hline $\mathrm{H}$ & 6.82865 & 1.84602 & 4.35380 \\
\hline $\mathrm{H}$ & 5.98039 & 4.03716 & 5.19368 \\
\hline $\mathrm{H}$ & 4.01222 & 5.08818 & 4.11436 \\
\hline $\mathrm{H}$ & 2.73440 & -5.81928 & 1.85869 \\
\hline $\mathrm{H}$ & 2.15046 & -5.58902 & -2.37023 \\
\hline $\mathrm{H}$ & -2.29832 & 5.47104 & 1.13417 \\
\hline $\mathrm{H}$ & 0.08937 & 6.12286 & -2.35138 \\
\hline $\mathrm{H}$ & 2.92230 & 4.01329 & -1.13430 \\
\hline $\mathrm{H}$ & 3.16513 & 6.48353 & -0.94562 \\
\hline $\mathrm{H}$ & 3.90165 & 5.85160 & -2.43125 \\
\hline
\end{tabular}




$\begin{array}{lrrr}\mathrm{H} & 2.34639 & 6.69315 & -2.50142 \\ \mathrm{H} & 1.55242 & 2.94970 & -2.88577 \\ \mathrm{H} & 1.30607 & 4.52273 & -3.68464 \\ \mathrm{H} & 2.92536 & 3.81669 & -3.59263 \\ \mathrm{H} & -1.86861 & 7.26515 & -2.18097 \\ \mathrm{H} & -1.52066 & 8.59738 & -0.09635 \\ \mathrm{H} & -3.15895 & 8.81227 & -0.74620 \\ \mathrm{H} & -2.89248 & 7.77984 & 0.66680 \\ \mathrm{H} & -3.47842 & 5.39529 & -2.28544 \\ \mathrm{H} & -4.05460 & 5.76102 & -0.64331 \\ \mathrm{H} & -4.32477 & 6.91932 & -1.95457 \\ \mathrm{H} & 0.20337 & 3.23109 & 2.75944 \\ \mathrm{H} & -1.67068 & 2.02813 & 1.81911 \\ \mathrm{H} & -2.04765 & 2.47758 & 3.48957 \\ \mathrm{H} & -2.79341 & 3.37615 & 2.15722 \\ \mathrm{H} & 0.04111 & 5.58276 & 3.61054 \\ \mathrm{H} & -1.71445 & 5.53983 & 3.40001 \\ \mathrm{H} & -0.94056 & 4.45432 & 4.56380 \\ \mathrm{H} & 1.79348 & -7.61936 & 0.80530 \\ \mathrm{H} & 3.87870 & -8.17748 & -0.43963 \\ \mathrm{H} & 3.02398 & -8.00109 & -1.97931 \\ \mathrm{H} & 2.56413 & -9.29542 & -0.85879 \\ \mathrm{H} & 0.49849 & -7.20582 & -1.94891 \\ \mathrm{H} & 0.14255 & -8.50955 & -0.80819 \\ \mathrm{H} & -0.25698 & -6.83211 & -0.39408 \\ \mathrm{H} & 3.32258 & -2.06079 & -2.61706 \\ \mathrm{H} & 0.95779 & -2.61347 & -2.99526 \\ \mathrm{H} & 1.85263 & -2.53223 & -4.51879 \\ \mathrm{H} & 1.40621 & -4.10804 & -3.85335 \\ \mathrm{H} & 5.16079 & -3.67116 & -3.17258 \\ \mathrm{H} & 3.98493 & -4.76015 & -3.92158 \\ \mathrm{H} & 4.28331 & -3.16113 & -4.62566 \\ \mathrm{H} & 4.21283 & -2.39091 & 2.09867 \\ \mathrm{H} & 5.78660 & -4.32023 & 2.14767 \\ \mathrm{H} & 5.34956 & -3.77707 & 3.77937 \\ & 4.63194 & -5.25166 & 3.11395 \\ 1.90429 & -2.54321 & 2.93109 \\ 2.19710 & -4.18734 & 3.54595 \\ 3.05861 & -2.80962 & 4.24806\end{array}$

\section{TS7-Z}

B3LYP/6-31G(d) Energy = -3928.453639

B3LYP/6-31G(d) Free Energy = -3927.077004

B3LYP/6-311+G(d,p) Derived free energy $=-3928.027416$

B3LYP $/ 6-311+G(d, p)$ Derived free energy in solution $=-3928.040010$

Number of Imaginary Frequencies $=1(-906.38)$ 


\begin{tabular}{|c|c|c|c|}
\hline \multicolumn{4}{|c|}{ B3LYP/6-31G(d) Geometry } \\
\hline $\mathrm{C}$ & -6.05619 & -1.09923 & 0.71454 \\
\hline $\mathrm{C}$ & -5.48096 & -2.23570 & 1.39268 \\
\hline $\mathrm{C}$ & -5.68174 & 0.21584 & 0.87644 \\
\hline $\mathrm{N}$ & -6.14740 & 1.28801 & 0.20592 \\
\hline $\mathrm{C}$ & -7.09500 & 1.21442 & -0.90994 \\
\hline $\mathrm{C}$ & -6.68309 & 2.20522 & -2.00319 \\
\hline $\mathrm{O}$ & -6.53151 & 3.51966 & -1.48674 \\
\hline $\mathrm{C}$ & -5.52224 & 3.55839 & -0.48989 \\
\hline $\mathrm{C}$ & -5.88335 & 2.64827 & 0.68440 \\
\hline $\mathrm{H}$ & -4.95001 & 0.46471 & 1.63945 \\
\hline $\mathrm{C}$ & -4.09086 & -3.33733 & -0.69856 \\
\hline $\mathrm{C}$ & -2.82416 & -3.83698 & -0.15139 \\
\hline $\mathrm{C}$ & -1.67871 & -3.08514 & -0.33897 \\
\hline $\mathrm{N}$ & -1.75313 & -1.94977 & -1.10613 \\
\hline $\mathrm{C}$ & -2.85431 & -1.52250 & -1.78618 \\
\hline $\mathrm{C}$ & -4.03639 & -2.24353 & -1.66935 \\
\hline $\mathrm{C}$ & -2.63230 & -0.30878 & -2.64535 \\
\hline $\mathrm{C}$ & -0.30561 & -3.34818 & 0.21541 \\
\hline $\mathrm{C}$ & -5.22490 & -1.91079 & -2.48623 \\
\hline $\mathrm{C}$ & -2.96200 & -5.09134 & 0.63960 \\
\hline $\mathrm{C}$ & -6.31649 & -2.96748 & -2.62699 \\
\hline $\mathrm{O}$ & -5.35235 & -0.83646 & -3.07389 \\
\hline $\mathrm{C}$ & -1.79186 & -5.79082 & 1.30512 \\
\hline $\mathrm{O}$ & -4.08528 & -5.57942 & 0.76280 \\
\hline $\mathrm{C}$ & 5.38374 & 2.25435 & 2.44686 \\
\hline $\mathrm{C}$ & 4.19986 & 2.72633 & 1.81505 \\
\hline $\mathrm{C}$ & 3.62187 & 3.94530 & 2.29401 \\
\hline $\mathrm{C}$ & 4.26326 & 4.65856 & 3.34219 \\
\hline $\mathrm{C}$ & 5.41547 & 4.18036 & 3.92235 \\
\hline $\mathrm{C}$ & 5.97187 & 2.95921 & 3.47408 \\
\hline $\mathrm{C}$ & 3.54587 & 2.01885 & 0.74818 \\
\hline $\mathrm{C}$ & 2.29338 & 2.45187 & 0.33407 \\
\hline $\mathrm{C}$ & 1.73396 & 3.69553 & 0.75229 \\
\hline $\mathrm{C}$ & 2.42293 & 4.41923 & 1.70403 \\
\hline $\mathrm{C}$ & 4.19430 & 0.86711 & 0.05930 \\
\hline $\mathrm{C}$ & 5.48194 & 1.02351 & -0.56507 \\
\hline $\mathrm{C}$ & 6.12409 & -0.12506 & -1.12766 \\
\hline $\mathrm{C}$ & 5.45426 & -1.37186 & -1.09468 \\
\hline $\mathrm{C}$ & 4.17574 & -1.51191 & -0.59510 \\
\hline $\mathrm{C}$ & 3.54453 & -0.35876 & -0.03516 \\
\hline $\mathrm{C}$ & 6.14553 & 2.27739 & -0.68522 \\
\hline $\mathrm{C}$ & 7.38019 & 2.37706 & -1.28806 \\
\hline $\mathrm{C}$ & 8.02840 & 1.23035 & -1.80388 \\
\hline $\mathrm{C}$ & 7.40590 & 0.00652 & -1.72673 \\
\hline
\end{tabular}




\begin{tabular}{|c|c|c|c|}
\hline $\mathrm{C}$ & 0.49275 & 4.27237 & 0.13634 \\
\hline $\mathrm{O}$ & 2.29389 & -0.51119 & 0.52085 \\
\hline $\mathrm{O}$ & 1.59574 & 1.69850 & -0.59005 \\
\hline $\mathrm{C}$ & 3.53394 & -2.86838 & -0.64071 \\
\hline $\mathrm{C}$ & 0.54696 & 4.81094 & -1.17305 \\
\hline $\mathrm{C}$ & -0.57329 & 5.47566 & -1.67978 \\
\hline $\mathrm{C}$ & -1.74653 & 5.63626 & -0.93792 \\
\hline $\mathrm{C}$ & -1.78577 & 5.07135 & 0.33740 \\
\hline $\mathrm{C}$ & -0.69661 & 4.38417 & 0.89098 \\
\hline $\mathrm{C}$ & 3.46632 & -3.66251 & 0.52809 \\
\hline $\mathrm{C}$ & 3.00134 & -4.97902 & 0.42610 \\
\hline $\mathrm{C}$ & 2.61085 & -5.54415 & -0.79127 \\
\hline $\mathrm{C}$ & 2.66346 & -4.73265 & -1.92694 \\
\hline $\mathrm{C}$ & 3.10978 & -3.40575 & -1.88036 \\
\hline $\mathrm{P}$ & 0.93504 & 0.26245 & -0.07351 \\
\hline $\mathrm{O}$ & 0.48101 & -0.43382 & -1.34097 \\
\hline $\mathrm{O}$ & 0.00290 & 0.43054 & 1.08211 \\
\hline $\mathrm{C}$ & 3.13677 & -2.60024 & -3.18080 \\
\hline $\mathrm{C}$ & 1.74005 & -2.48576 & -3.82043 \\
\hline $\mathrm{C}$ & 4.15764 & -3.17791 & -4.18093 \\
\hline $\mathrm{C}$ & 2.21471 & -7.01523 & -0.86082 \\
\hline $\mathrm{C}$ & 3.41491 & -7.88048 & -1.29774 \\
\hline $\mathrm{C}$ & 0.99870 & -7.28931 & -1.76194 \\
\hline $\mathrm{C}$ & 3.92349 & -3.14618 & 1.89208 \\
\hline $\mathrm{C}$ & 5.09773 & -3.97435 & 2.44935 \\
\hline $\mathrm{C}$ & 2.76018 & -3.07943 & 2.89985 \\
\hline $\mathrm{C}$ & -2.92525 & 6.43598 & -1.47929 \\
\hline $\mathrm{C}$ & -3.43577 & 5.90700 & -2.83195 \\
\hline $\mathrm{C}$ & -2.58490 & 7.93668 & -1.57300 \\
\hline $\mathrm{C}$ & -0.83515 & 3.78617 & 2.29101 \\
\hline $\mathrm{C}$ & -2.02215 & 2.80990 & 2.38247 \\
\hline $\mathrm{C}$ & -0.93794 & 4.88031 & 3.37120 \\
\hline $\mathrm{C}$ & 1.79520 & 4.72111 & -2.05085 \\
\hline $\mathrm{C}$ & 2.34701 & 6.11597 & -2.40482 \\
\hline $\mathrm{C}$ & 1.53560 & 3.88319 & -3.31756 \\
\hline $\mathrm{H}$ & -6.88493 & -1.32419 & 0.04968 \\
\hline $\mathrm{H}$ & -8.10537 & 1.45132 & -0.54609 \\
\hline $\mathrm{H}$ & -7.09142 & 0.20913 & -1.33001 \\
\hline $\mathrm{H}$ & -5.74995 & 1.85797 & -2.47046 \\
\hline $\mathrm{H}$ & -7.46010 & 2.25558 & -2.77070 \\
\hline $\mathrm{H}$ & -4.54960 & 3.25784 & -0.90947 \\
\hline $\mathrm{H}$ & -5.45030 & 4.59604 & -0.15325 \\
\hline $\mathrm{H}$ & -6.78323 & 3.03762 & 1.18304 \\
\hline $\mathrm{H}$ & -5.06828 & 2.61838 & 1.41257 \\
\hline $\mathrm{H}$ & -4.73507 & -2.85540 & 0.32210 \\
\hline $\mathrm{H}$ & -4.80256 & -4.13765 & -0.90076 \\
\hline
\end{tabular}




\begin{tabular}{|c|c|c|c|}
\hline $\mathrm{H}$ & -0.87928 & -1.36387 & -1.18768 \\
\hline $\mathrm{H}$ & -1.57902 & -0.02062 & -2.63333 \\
\hline $\mathrm{H}$ & -2.96340 & -0.49495 & -3.67042 \\
\hline $\mathrm{H}$ & -3.23859 & 0.52598 & -2.28190 \\
\hline $\mathrm{H}$ & -0.30194 & -3.21910 & 1.30264 \\
\hline $\mathrm{H}$ & 0.04324 & -4.35653 & -0.00767 \\
\hline $\mathrm{H}$ & 0.41815 & -2.65057 & -0.20508 \\
\hline $\mathrm{H}$ & -5.90541 & -3.91995 & -2.98235 \\
\hline $\mathrm{H}$ & -6.81636 & -3.17174 & -1.67320 \\
\hline $\mathrm{H}$ & -7.05465 & -2.60211 & -3.34339 \\
\hline $\mathrm{H}$ & -1.04132 & -6.11317 & 0.57581 \\
\hline $\mathrm{H}$ & -2.18597 & -6.66767 & 1.82212 \\
\hline $\mathrm{H}$ & -1.28973 & -5.14034 & 2.02793 \\
\hline $\mathrm{H}$ & 5.81705 & 1.31608 & 2.11930 \\
\hline $\mathrm{H}$ & 3.81561 & 5.58837 & 3.68588 \\
\hline $\mathrm{H}$ & 5.89314 & 4.73051 & 4.72865 \\
\hline $\mathrm{H}$ & 6.87000 & 2.57114 & 3.94738 \\
\hline $\mathrm{H}$ & 2.03152 & 5.38237 & 2.02186 \\
\hline $\mathrm{H}$ & 5.95936 & -2.24448 & -1.50151 \\
\hline $\mathrm{H}$ & 5.66324 & 3.17028 & -0.30616 \\
\hline $\mathrm{H}$ & 7.85844 & 3.34933 & -1.37285 \\
\hline $\mathrm{H}$ & 9.00554 & 1.32202 & -2.27039 \\
\hline $\mathrm{H}$ & 7.87915 & -0.88264 & -2.13720 \\
\hline $\mathrm{H}$ & -0.51778 & 5.89855 & -2.67985 \\
\hline $\mathrm{H}$ & -2.69211 & 5.18423 & 0.92988 \\
\hline $\mathrm{H}$ & 2.96478 & -5.59583 & 1.32239 \\
\hline $\mathrm{H}$ & 2.35987 & -5.14201 & -2.88672 \\
\hline $\mathrm{H}$ & 3.45491 & -1.58265 & -2.94029 \\
\hline $\mathrm{H}$ & 1.05322 & -1.97401 & -3.14118 \\
\hline $\mathrm{H}$ & 1.79980 & -1.90066 & -4.74648 \\
\hline $\mathrm{H}$ & 1.32536 & -3.46845 & -4.07775 \\
\hline $\mathrm{H}$ & 5.16462 & -3.21753 & -3.75039 \\
\hline $\mathrm{H}$ & 3.88826 & -4.19588 & -4.48823 \\
\hline $\mathrm{H}$ & 4.20021 & -2.55799 & -5.08452 \\
\hline $\mathrm{H}$ & 1.94517 & -7.32388 & 0.15942 \\
\hline $\mathrm{H}$ & 4.27050 & -7.73472 & -0.62970 \\
\hline $\mathrm{H}$ & 3.15271 & -8.94572 & -1.29218 \\
\hline $\mathrm{H}$ & 3.73529 & -7.61561 & -2.31254 \\
\hline $\mathrm{H}$ & 0.13589 & -6.67543 & -1.47832 \\
\hline $\mathrm{H}$ & 1.21913 & -7.08097 & -2.81519 \\
\hline $\mathrm{H}$ & 0.70225 & -8.34250 & -1.69377 \\
\hline $\mathrm{H}$ & 4.28946 & -2.12447 & 1.76095 \\
\hline $\mathrm{H}$ & 5.93897 & -3.99018 & 1.74739 \\
\hline $\mathrm{H}$ & 5.45215 & -3.54634 & 3.39486 \\
\hline $\mathrm{H}$ & 4.80624 & -5.01333 & 2.64442 \\
\hline $\mathrm{H}$ & 1.97067 & -2.41727 & 2.53109 \\
\hline
\end{tabular}




$\begin{array}{llrr}\mathrm{H} & 2.32899 & -4.07153 & 3.08415 \\ \mathrm{H} & 3.11181 & -2.68662 & 3.86182 \\ \mathrm{H} & -3.74536 & 6.33475 & -0.75390 \\ \mathrm{H} & -3.71903 & 4.85082 & -2.76934 \\ \mathrm{H} & -2.67100 & 6.00029 & -3.61169 \\ \mathrm{H} & -4.31492 & 6.47374 & -3.16092 \\ \mathrm{H} & -1.77326 & 8.11164 & -2.28909 \\ \mathrm{H} & -3.45629 & 8.51403 & -1.90573 \\ \mathrm{H} & -2.26274 & 8.33016 & -0.60273 \\ \mathrm{H} & 0.06201 & 3.19606 & 2.49403 \\ \mathrm{H} & -1.90558 & 2.00649 & 1.65039 \\ \mathrm{H} & -2.06110 & 2.35558 & 3.38009 \\ \mathrm{H} & -2.97907 & 3.32323 & 2.21703 \\ \mathrm{H} & -0.06711 & 5.54490 & 3.35459 \\ \mathrm{H} & -1.83049 & 5.50221 & 3.22786 \\ \mathrm{H} & -1.00058 & 4.43109 & 4.37003 \\ \mathrm{H} & 2.57650 & 4.20863 & -1.48406 \\ \mathrm{H} & 2.56485 & 6.69753 & -1.50182 \\ \mathrm{H} & 3.27507 & 6.02330 & -2.98185 \\ \mathrm{H} & 1.63753 & 6.69277 & -3.01009 \\ \mathrm{H} & 1.20003 & 2.87621 & -3.05290 \\ \mathrm{H} & 0.77246 & 4.34532 & -3.95601 \\ \mathrm{H} & 2.45456 & 3.79350 & -3.90972 \\ \mathrm{C} & -2.21519 & -1.76330 & 4.21322 \\ \mathrm{C} & -2.16328 & -1.16170 & 2.94709 \\ \mathrm{C} & -3.21848 & -1.30961 & 2.04986 \\ \mathrm{C} & -4.36753 & -2.06157 & 2.37049 \\ \mathrm{C} & -4.39587 & -2.68632 & 3.63094 \\ \mathrm{C} & -3.34648 & -2.52745 & 4.53291 \\ \mathrm{C} & -1.08761 & -1.58234 & 5.20034 \\ \mathrm{H} & -1.29370 & -0.58667 & 2.63389 \\ \mathrm{H} & -3.12303 & -0.85305 & 1.07026 \\ \mathrm{H} & -5.24835 & -3.29176 & 3.92016 \\ \mathrm{H} & -3.40627 & -3.01326 & 5.50438 \\ \mathrm{H} & -1.18759 & -0.63081 & 5.73939 \\ \mathrm{H} & -1.07314 & -2.38235 & 5.94796 \\ -0.11622 & -1.56177 & 4.69558 \\ \mathrm{H} & -6.46291 & -3.37452 & 1.65396 \\ \mathrm{H} & -7.09794 & -3.13108 & 2.51586 \\ \mathrm{H} & & -3.51139 & 0.79571\end{array}$

TS8-E

B3LYP/6-31G(d) Energy $=-3928.454837$

B3LYP/6-31G(d) Free Energy = -3927.076514

B3LYP/6-311+G(d,p) Derived free energy $=-3928.026297$ 
B3LYP/6-311+G(d,p) Derived free energy in solution $=-3928.038096$ Number of Imaginary Frequencies $=1(-939.39)$

$\begin{array}{lccc}\text { B3LYP/6-31G(d) } & \text { Geometry } & \\ \text { C } & -3.96566 & -2.27406 & 0.57608 \\ \text { C } & -3.73418 & -3.47906 & 1.34108 \\ \text { C } & -4.84271 & -2.17000 & -0.47762 \\ \text { C } & -2.85290 & -3.33988 & 2.54379 \\ \text { C } & -4.85354 & -4.51231 & 1.43620 \\ \text { C } & -1.79580 & -2.40769 & 2.56880 \\ \text { C } & -0.98262 & -2.26980 & 3.69171 \\ \text { C } & -1.17430 & -3.05899 & 4.83289 \\ \text { C } & -2.20975 & -4.00423 & 4.80149 \\ \text { C } & -3.02670 & -4.14729 & 3.68434 \\ \text { C } & -0.31779 & -2.88073 & 6.06296 \\ \text { N } & -5.04400 & -1.10127 & -1.28014 \\ \text { C } & -6.20281 & -1.06425 & -2.17738 \\ \text { C } & -5.84607 & -0.34505 & -3.47690 \\ \text { O } & -5.33205 & 0.94962 & -3.20815 \\ \text { C } & -4.13392 & 0.86994 & -2.44340 \\ \text { C } & -4.36334 & 0.18607 & -1.09382 \\ \text { H } & -5.47472 & -3.01324 & -0.74035 \\ \text { C } & -2.08417 & -4.81168 & -0.37673 \\ \text { C } & -0.76459 & -4.67525 & 0.24475 \\ \text { C } & 0.00402 & -3.58418 & -0.11088 \\ \text { N } & -0.44224 & -2.77691 & -1.13136 \\ \text { C } & -1.51126 & -3.03239 & -1.93453 \\ \text { C } & -2.32851 & -4.11709 & -1.63486 \\ \text { C } & -1.64408 & -2.11776 & -3.11763 \\ \text { C } & 1.30822 & -3.13755 & 0.48817 \\ \text { C } & -3.42988 & -4.53667 & -2.53660 \\ \text { C } & -0.47783 & -5.69945 & 1.29028 \\ \text { C } & -4.07363 & -5.89863 & -2.29722 \\ \text { O } & -3.82235 & -3.84667 & -3.47513 \\ \text { C } & 0.82500 & -5.73859 & 2.06526 \\ \text { O } & -1.33761 & -6.54512 & 1.52797 \\ \text { C } & 3.97159 & 4.79287 & -1.11791 \\ \text { C } & 4.04130 & 3.38512 & -0.92089 \\ \text { C } & 5.13074 & 2.67879 & -1.52205 \\ \text { C } & 6.12150 & 3.39760 & -2.24385 \\ \text { C } & 6.03288 & 4.76131 & -2.39910 \\ \text { C } & 4.93764 & 5.45996 & -1.83855 \\ \text { C } & 3.05886 & 2.64352 & -0.17747 \\ \text { C } & 3.10615 & 1.25562 & -0.19411 \\ \text { C } & 4.19852 & 0.53857 & -0.77188 \\ \text { C } & 5.19183 & 1.27007 & -1.39133 \\ & & & \\ & & & \end{array}$




\begin{tabular}{|c|c|c|c|}
\hline $\mathrm{C}$ & 1.99587 & 3.34637 & 0.59383 \\
\hline $\mathrm{C}$ & 2.33641 & 4.30226 & 1.61243 \\
\hline $\mathrm{C}$ & 1.29375 & 5.07965 & 2.20795 \\
\hline $\mathrm{C}$ & -0.04113 & 4.87656 & 1.78168 \\
\hline $\mathrm{C}$ & -0.39147 & 3.89208 & 0.87903 \\
\hline $\mathrm{C}$ & 0.65512 & 3.08863 & 0.33250 \\
\hline $\mathrm{C}$ & 3.66425 & 4.49363 & 2.08741 \\
\hline $\mathrm{C}$ & 3.94225 & 5.41660 & 3.07148 \\
\hline $\mathrm{C}$ & 2.91173 & 6.20729 & 3.63273 \\
\hline $\mathrm{C}$ & 1.61469 & 6.03691 & 3.20788 \\
\hline $\mathrm{C}$ & 4.34459 & -0.95330 & -0.69342 \\
\hline $\mathrm{O}$ & 0.32526 & 2.09050 & -0.56523 \\
\hline $\mathrm{O}$ & 2.11883 & 0.54768 & 0.46057 \\
\hline $\mathrm{C}$ & -1.83452 & 3.78812 & 0.47478 \\
\hline $\mathrm{C}$ & 4.72342 & -1.56366 & 0.52546 \\
\hline $\mathrm{C}$ & 4.98607 & -2.93935 & 0.54168 \\
\hline $\mathrm{C}$ & 4.90017 & -3.73219 & -0.60473 \\
\hline $\mathrm{C}$ & 4.51037 & -3.10997 & -1.79369 \\
\hline $\mathrm{C}$ & 4.22691 & -1.74090 & -1.86617 \\
\hline $\mathrm{C}$ & -2.25727 & 4.32448 & -0.76517 \\
\hline $\mathrm{C}$ & -3.62887 & 4.41234 & -1.03861 \\
\hline $\mathrm{C}$ & -4.60026 & 3.98702 & -0.12734 \\
\hline $\mathrm{C}$ & -4.15456 & 3.41781 & 1.06881 \\
\hline $\mathrm{C}$ & -2.79672 & 3.30969 & 1.39495 \\
\hline $\mathrm{P}$ & 0.56334 & 0.49357 & -0.15102 \\
\hline $\mathrm{O}$ & -0.32525 & 0.05486 & 0.97001 \\
\hline $\mathrm{O}$ & 0.57603 & -0.26533 & -1.46216 \\
\hline $\mathrm{C}$ & -2.41242 & 2.69715 & 2.74192 \\
\hline $\mathrm{C}$ & -2.92192 & 1.25126 & 2.87744 \\
\hline $\mathrm{C}$ & -2.89244 & 3.56703 & 3.92015 \\
\hline $\mathrm{C}$ & -6.09373 & 4.20680 & -0.35114 \\
\hline $\mathrm{C}$ & -6.55511 & 4.03244 & -1.80704 \\
\hline $\mathrm{C}$ & -6.50894 & 5.59390 & 0.18434 \\
\hline $\mathrm{C}$ & -1.27040 & 4.85285 & -1.80629 \\
\hline $\mathrm{C}$ & -1.49813 & 6.34638 & -2.11017 \\
\hline $\mathrm{C}$ & -1.30093 & 4.00858 & -3.09473 \\
\hline $\mathrm{C}$ & 5.27539 & -5.20896 & -0.55725 \\
\hline $\mathrm{C}$ & 6.62392 & -5.46040 & -1.26109 \\
\hline $\mathrm{C}$ & 4.18348 & -6.12832 & -1.13298 \\
\hline $\mathrm{C}$ & 3.82923 & -1.14959 & -3.22028 \\
\hline $\mathrm{C}$ & 2.58949 & -1.83922 & -3.81834 \\
\hline $\mathrm{C}$ & 5.00639 & -1.18435 & -4.21535 \\
\hline $\mathrm{C}$ & 4.90928 & -0.76782 & 1.81738 \\
\hline $\mathrm{C}$ & 6.36711 & -0.83100 & 2.31431 \\
\hline $\mathrm{C}$ & 3.92578 & -1.21229 & 2.91627 \\
\hline $\mathrm{H}$ & -3.35532 & -1.41515 & 0.82341 \\
\hline
\end{tabular}




\begin{tabular}{|c|c|c|c|}
\hline $\mathrm{H}$ & -5.59708 & -4.19716 & 2.17848 \\
\hline $\mathrm{H}$ & -4.46449 & -5.49057 & 1.73012 \\
\hline $\mathrm{H}$ & -5.37420 & -4.63827 & 0.48434 \\
\hline $\mathrm{H}$ & -1.57683 & -1.76264 & 1.72415 \\
\hline $\mathrm{H}$ & -0.19434 & -1.52141 & 3.66540 \\
\hline $\mathrm{H}$ & -2.38163 & -4.63939 & 5.66759 \\
\hline $\mathrm{H}$ & -3.81332 & -4.89268 & 3.71459 \\
\hline $\mathrm{H}$ & -0.78295 & -2.17822 & 6.76758 \\
\hline $\mathrm{H}$ & 0.66852 & -2.47877 & 5.80983 \\
\hline $\mathrm{H}$ & -0.17652 & -3.82723 & 6.59610 \\
\hline $\mathrm{H}$ & -7.03267 & -0.53287 & -1.68686 \\
\hline $\mathrm{H}$ & -6.52037 & -2.08981 & -2.38760 \\
\hline $\mathrm{H}$ & -5.11383 & -0.94297 & -4.04163 \\
\hline $\mathrm{H}$ & -6.74143 & -0.21070 & -4.09066 \\
\hline $\mathrm{H}$ & -3.36534 & 0.32986 & -3.01452 \\
\hline $\mathrm{H}$ & -3.79395 & 1.89338 & -2.27643 \\
\hline $\mathrm{H}$ & -4.96859 & 0.83357 & -0.44471 \\
\hline $\mathrm{H}$ & -3.39871 & 0.02975 & -0.60719 \\
\hline $\mathrm{H}$ & -2.87407 & -4.21515 & 0.49253 \\
\hline $\mathrm{H}$ & -2.49321 & -5.81445 & -0.27269 \\
\hline $\mathrm{H}$ & 0.04950 & -1.85935 & -1.28034 \\
\hline $\mathrm{H}$ & -2.67578 & -1.78895 & -3.23178 \\
\hline $\mathrm{H}$ & -0.97310 & -1.26202 & -3.01307 \\
\hline $\mathrm{H}$ & -1.39915 & -2.66023 & -4.03864 \\
\hline $\mathrm{H}$ & 1.70094 & -2.27133 & -0.04334 \\
\hline $\mathrm{H}$ & 1.17375 & -2.85465 & 1.53600 \\
\hline $\mathrm{H}$ & 2.06719 & -3.92012 & 0.43977 \\
\hline $\mathrm{H}$ & -4.57521 & -5.95460 & -1.32445 \\
\hline $\mathrm{H}$ & -4.80666 & -6.07174 & -3.08709 \\
\hline $\mathrm{H}$ & -3.32432 & -6.69915 & -2.31540 \\
\hline $\mathrm{H}$ & 1.69341 & -5.82245 & 1.40344 \\
\hline $\mathrm{H}$ & 0.79027 & -6.60705 & 2.72555 \\
\hline $\mathrm{H}$ & 0.95362 & -4.83407 & 2.66856 \\
\hline $\mathrm{H}$ & 3.13564 & 5.34388 & -0.70325 \\
\hline $\mathrm{H}$ & 6.94693 & 2.84262 & -2.68395 \\
\hline $\mathrm{H}$ & 6.79162 & 5.30096 & -2.95937 \\
\hline $\mathrm{H}$ & 4.85457 & 6.53408 & -1.98186 \\
\hline $\mathrm{H}$ & 6.04615 & 0.74641 & -1.81273 \\
\hline $\mathrm{H}$ & -0.82027 & 5.51441 & 2.19138 \\
\hline $\mathrm{H}$ & 4.46479 & 3.89051 & 1.67505 \\
\hline $\mathrm{H}$ & 4.96364 & 5.53532 & 3.42344 \\
\hline $\mathrm{H}$ & 3.14601 & 6.93678 & 4.40333 \\
\hline $\mathrm{H}$ & 0.80843 & 6.62517 & 3.64016 \\
\hline $\mathrm{H}$ & 5.29305 & -3.40560 & 1.47603 \\
\hline $\mathrm{H}$ & 4.43704 & -3.70313 & -2.70191 \\
\hline $\mathrm{H}$ & -3.94205 & 4.85237 & -1.98135 \\
\hline
\end{tabular}




\begin{tabular}{|c|c|c|c|}
\hline $\mathrm{H}$ & -4.89575 & 3.07171 & 1.78719 \\
\hline $\mathrm{H}$ & -1.32158 & 2.64766 & 2.78994 \\
\hline $\mathrm{H}$ & -2.47984 & 0.62726 & 2.09666 \\
\hline $\mathrm{H}$ & -2.62355 & 0.83312 & 3.84631 \\
\hline $\mathrm{H}$ & -4.01579 & 1.19284 & 2.81479 \\
\hline $\mathrm{H}$ & -2.56508 & 3.13393 & 4.87308 \\
\hline $\mathrm{H}$ & -3.98654 & 3.64074 & 3.94666 \\
\hline $\mathrm{H}$ & -2.49338 & 4.58571 & 3.85751 \\
\hline $\mathrm{H}$ & -6.62132 & 3.45542 & 0.25455 \\
\hline $\mathrm{H}$ & -6.28533 & 3.05202 & -2.21253 \\
\hline $\mathrm{H}$ & -7.64515 & 4.13723 & -1.86781 \\
\hline $\mathrm{H}$ & -6.12389 & 4.79910 & -2.46177 \\
\hline $\mathrm{H}$ & -6.23634 & 5.71131 & 1.23876 \\
\hline $\mathrm{H}$ & -6.01021 & 6.39119 & -0.37996 \\
\hline $\mathrm{H}$ & -7.59227 & 5.73974 & 0.09129 \\
\hline $\mathrm{H}$ & -0.26232 & 4.76538 & -1.39321 \\
\hline $\mathrm{H}$ & -1.44376 & 6.94947 & -1.19682 \\
\hline $\mathrm{H}$ & -0.73415 & 6.71359 & -2.80597 \\
\hline $\mathrm{H}$ & -2.47701 & 6.52486 & -2.57073 \\
\hline $\mathrm{H}$ & -1.06337 & 2.96267 & -2.87692 \\
\hline $\mathrm{H}$ & -2.28417 & 4.04964 & -3.58000 \\
\hline $\mathrm{H}$ & -0.56067 & 4.38120 & -3.81313 \\
\hline $\mathrm{H}$ & 5.40431 & -5.47471 & 0.50132 \\
\hline $\mathrm{H}$ & 7.41713 & -4.84360 & -0.82513 \\
\hline $\mathrm{H}$ & 6.56107 & -5.21689 & -2.32843 \\
\hline $\mathrm{H}$ & 6.92017 & -6.51285 & -1.17275 \\
\hline $\mathrm{H}$ & 4.01988 & -5.94102 & -2.20053 \\
\hline $\mathrm{H}$ & 4.46899 & -7.18124 & -1.02326 \\
\hline $\mathrm{H}$ & 3.22475 & -5.98365 & -0.62133 \\
\hline $\mathrm{H}$ & 3.55802 & -0.10258 & -3.06441 \\
\hline $\mathrm{H}$ & 1.73535 & -1.72555 & -3.14698 \\
\hline $\mathrm{H}$ & 2.32931 & -1.37511 & -4.77750 \\
\hline $\mathrm{H}$ & 2.75945 & -2.90691 & -4.00385 \\
\hline $\mathrm{H}$ & 5.88161 & -0.65374 & -3.82445 \\
\hline $\mathrm{H}$ & 5.31470 & -2.21395 & -4.43483 \\
\hline $\mathrm{H}$ & 4.72062 & -0.71245 & -5.16316 \\
\hline $\mathrm{H}$ & 4.69310 & 0.28193 & 1.60337 \\
\hline $\mathrm{H}$ & 7.06313 & -0.47846 & 1.54492 \\
\hline $\mathrm{H}$ & 6.49504 & -0.20097 & 3.20283 \\
\hline $\mathrm{H}$ & 6.65985 & -1.85207 & 2.58658 \\
\hline $\mathrm{H}$ & 2.89197 & -1.07994 & 2.58304 \\
\hline $\mathrm{H}$ & 4.07432 & -2.26443 & 3.18995 \\
\hline $\mathrm{H}$ & 4.07006 & -0.61050 & 3.82186 \\
\hline
\end{tabular}

TS8-Z

B3LYP/6-31G(d) Energy $=-3928.450133$ 
B3LYP/6-31G(d) Free Energy = -3927.073761

B3LYP/6-311+G(d,p) Derived free energy $=-3928.025084$

B3LYP/6-311+G(d,p) Derived free energy in solution $=-3928.037976$

Number of Imaginary Frequencies $=1(-949.50)$

\begin{tabular}{|c|c|c|c|}
\hline \multicolumn{4}{|c|}{ B3LYP/6-31G(d) Geometry } \\
\hline $\mathrm{C}$ & 4.36229 & 0.64683 & -0.38960 \\
\hline $\mathrm{C}$ & 5.08742 & -0.24123 & -1.25285 \\
\hline $\mathrm{C}$ & 4.79940 & 1.04974 & 0.85814 \\
\hline $\mathrm{C}$ & 6.59285 & -0.28983 & -1.24957 \\
\hline $\mathrm{C}$ & 4.46258 & -0.45443 & -2.62878 \\
\hline $\mathrm{C}$ & 7.36683 & 0.84801 & -0.97158 \\
\hline $\mathrm{C}$ & 8.75958 & 0.80598 & -1.04766 \\
\hline $\mathrm{C}$ & 9.43336 & -0.36745 & -1.40102 \\
\hline $\mathrm{C}$ & 8.65799 & -1.49902 & -1.69727 \\
\hline $\mathrm{C}$ & 7.26850 & -1.46457 & -1.63176 \\
\hline $\mathrm{C}$ & 10.94125 & -0.42309 & -1.45600 \\
\hline $\mathrm{N}$ & 4.16672 & 1.84601 & 1.73696 \\
\hline $\mathrm{C}$ & 4.71269 & 2.08679 & 3.07863 \\
\hline $\mathrm{C}$ & 4.60672 & 3.57327 & 3.42324 \\
\hline $\mathrm{O}$ & 3.26716 & 4.02165 & 3.30291 \\
\hline $\mathrm{C}$ & 2.79462 & 3.86369 & 1.97109 \\
\hline $\mathrm{C}$ & 2.82348 & 2.40149 & 1.52737 \\
\hline $\mathrm{H}$ & 5.77656 & 0.72127 & 1.20054 \\
\hline $\mathrm{C}$ & 4.33734 & -2.58074 & -0.05658 \\
\hline $\mathrm{C}$ & 3.24656 & -3.09877 & -0.89533 \\
\hline $\mathrm{C}$ & 1.95822 & -2.68845 & -0.60940 \\
\hline $\mathrm{N}$ & 1.74138 & -1.97270 & 0.54824 \\
\hline $\mathrm{C}$ & 2.67128 & -1.73563 & 1.51425 \\
\hline $\mathrm{C}$ & 3.99446 & -2.09546 & 1.27650 \\
\hline $\mathrm{C}$ & 2.12495 & -1.14520 & 2.78391 \\
\hline $\mathrm{C}$ & 0.71329 & -2.87292 & -1.42493 \\
\hline $\mathrm{C}$ & 5.04276 & -1.96757 & 2.32141 \\
\hline $\mathrm{C}$ & 3.70536 & -3.94502 & -2.02905 \\
\hline $\mathrm{C}$ & 6.38748 & -2.64178 & 2.07761 \\
\hline $\mathrm{O}$ & 4.86444 & -1.35258 & 3.37083 \\
\hline $\mathrm{C}$ & 2.78044 & -4.84244 & -2.83340 \\
\hline $\mathrm{O}$ & 4.90734 & -3.95870 & -2.30002 \\
\hline $\mathrm{C}$ & -6.58398 & 1.15830 & 1.04561 \\
\hline $\mathrm{C}$ & -5.75761 & 0.02029 & 0.82830 \\
\hline $\mathrm{C}$ & -6.15127 & -1.21738 & 1.43076 \\
\hline $\mathrm{C}$ & -7.36066 & -1.28255 & 2.17392 \\
\hline $\mathrm{C}$ & -8.14561 & -0.16650 & 2.34806 \\
\hline $\mathrm{C}$ & -7.74223 & 1.06751 & 1.78588 \\
\hline $\mathrm{C}$ & -4.54174 & 0.06484 & 0.06196 \\
\hline $\mathrm{C}$ & -3.71164 & -1.04855 & 0.05570 \\
\hline
\end{tabular}




\begin{tabular}{|c|c|c|c|}
\hline $\mathrm{C}$ & -4.09695 & -2.29354 & 0.64063 \\
\hline $\mathrm{C}$ & -5.31581 & -2.35241 & 1.28447 \\
\hline $\mathrm{C}$ & -4.15874 & 1.28295 & -0.70686 \\
\hline $\mathrm{C}$ & -5.03005 & 1.83066 & -1.71117 \\
\hline $\mathrm{C}$ & -4.68752 & 3.08021 & -2.31836 \\
\hline $\mathrm{C}$ & -3.50094 & 3.73923 & -1.91267 \\
\hline $\mathrm{C}$ & -2.61204 & 3.17970 & -1.01702 \\
\hline $\mathrm{C}$ & -2.93954 & 1.90513 & -0.46496 \\
\hline $\mathrm{C}$ & -6.20530 & 1.16930 & -2.16570 \\
\hline $\mathrm{C}$ & -7.00421 & 1.72611 & -3.14003 \\
\hline $\mathrm{C}$ & -6.67939 & 2.97867 & -3.71215 \\
\hline $\mathrm{C}$ & -5.54149 & 3.63730 & -3.30789 \\
\hline $\mathrm{C}$ & -3.24090 & -3.52203 & 0.55129 \\
\hline $\mathrm{O}$ & -2.04334 & 1.31047 & 0.40526 \\
\hline $\mathrm{O}$ & -2.52158 & -0.99389 & -0.63323 \\
\hline $\mathrm{C}$ & -1.41788 & 3.99516 & -0.60521 \\
\hline $\mathrm{C}$ & -3.12149 & -4.21695 & -0.67766 \\
\hline $\mathrm{C}$ & -2.37932 & -5.40221 & -0.71896 \\
\hline $\mathrm{C}$ & -1.75919 & -5.93416 & 0.41662 \\
\hline $\mathrm{C}$ & -1.88896 & -5.23024 & 1.61345 \\
\hline $\mathrm{C}$ & -2.61505 & -4.03578 & 1.71118 \\
\hline $\mathrm{C}$ & -0.31602 & 4.15120 & -1.47969 \\
\hline $\mathrm{C}$ & 0.66337 & 5.10029 & -1.16429 \\
\hline $\mathrm{C}$ & 0.59575 & 5.90455 & -0.02135 \\
\hline $\mathrm{C}$ & -0.46734 & 5.68559 & 0.85714 \\
\hline $\mathrm{C}$ & -1.47433 & 4.74668 & 0.59113 \\
\hline $\mathrm{P}$ & -1.24138 & -0.05113 & -0.12206 \\
\hline $\mathrm{O}$ & -0.40931 & 0.20834 & -1.33740 \\
\hline $\mathrm{O}$ & -0.61491 & -0.66753 & 1.11118 \\
\hline $\mathrm{C}$ & -2.60839 & 4.58749 & 1.60335 \\
\hline $\mathrm{C}$ & -3.34954 & 5.91223 & 1.86613 \\
\hline $\mathrm{C}$ & -2.09688 & 3.96091 & 2.91533 \\
\hline $\mathrm{C}$ & 1.62664 & 7.01433 & 0.17669 \\
\hline $\mathrm{C}$ & 1.80677 & 7.47902 & 1.63016 \\
\hline $\mathrm{C}$ & 1.28445 & 8.22022 & -0.72510 \\
\hline $\mathrm{C}$ & -0.18000 & 3.34554 & -2.77202 \\
\hline $\mathrm{C}$ & 1.16678 & 2.60374 & -2.85620 \\
\hline $\mathrm{C}$ & -0.39615 & 4.23533 & -4.01218 \\
\hline $\mathrm{C}$ & -0.98826 & -7.24752 & 0.36834 \\
\hline $\mathrm{C}$ & 0.25102 & -7.15966 & -0.54164 \\
\hline $\mathrm{C}$ & -1.88849 & -8.42815 & -0.04230 \\
\hline $\mathrm{C}$ & -2.70670 & -3.35271 & 3.07630 \\
\hline $\mathrm{C}$ & -1.31882 & -2.97432 & 3.62440 \\
\hline $\mathrm{C}$ & -3.48741 & -4.21532 & 4.08728 \\
\hline $\mathrm{C}$ & -3.82866 & -3.75168 & -1.95104 \\
\hline $\mathrm{C}$ & -4.89829 & -4.76870 & -2.39688 \\
\hline
\end{tabular}




\begin{tabular}{|c|c|c|c|}
\hline $\mathrm{C}$ & -2.84063 & -3.44655 & -3.09193 \\
\hline $\mathrm{H}$ & 3.35201 & 0.89216 & -0.70285 \\
\hline $\mathrm{H}$ & 4.88358 & -1.32900 & -3.12891 \\
\hline $\mathrm{H}$ & 4.66686 & 0.42353 & -3.25485 \\
\hline $\mathrm{H}$ & 3.37653 & -0.57103 & -2.55895 \\
\hline $\mathrm{H}$ & 6.87529 & 1.78482 & -0.72923 \\
\hline $\mathrm{H}$ & 9.32976 & 1.70804 & -0.83708 \\
\hline $\mathrm{H}$ & 9.15126 & -2.42297 & -1.99112 \\
\hline $\mathrm{H}$ & 6.69877 & -2.35618 & -1.88137 \\
\hline $\mathrm{H}$ & 11.28965 & -0.97631 & -2.33536 \\
\hline $\mathrm{H}$ & 11.35222 & -0.93058 & -0.57318 \\
\hline $\mathrm{H}$ & 11.37867 & 0.57965 & -1.49131 \\
\hline $\mathrm{H}$ & 5.75141 & 1.74657 & 3.10817 \\
\hline $\mathrm{H}$ & 4.14572 & 1.50036 & 3.81225 \\
\hline $\mathrm{H}$ & 4.90614 & 3.74118 & 4.46183 \\
\hline $\mathrm{H}$ & 5.26911 & 4.15978 & 2.76440 \\
\hline $\mathrm{H}$ & 1.76849 & 4.23331 & 1.94824 \\
\hline $\mathrm{H}$ & 3.40318 & 4.47100 & 1.28182 \\
\hline $\mathrm{H}$ & 2.54810 & 2.33880 & 0.47432 \\
\hline $\mathrm{H}$ & 2.09642 & 1.81847 & 2.10632 \\
\hline $\mathrm{H}$ & 4.77190 & -1.51639 & -0.68529 \\
\hline $\mathrm{H}$ & 5.24802 & -3.17001 & -0.13774 \\
\hline $\mathrm{H}$ & 0.78414 & -1.56791 & 0.71090 \\
\hline $\mathrm{H}$ & 2.75963 & -0.33500 & 3.13741 \\
\hline $\mathrm{H}$ & 1.10095 & -0.79955 & 2.63076 \\
\hline $\mathrm{H}$ & 2.13445 & -1.90085 & 3.57869 \\
\hline $\mathrm{H}$ & -0.04012 & -3.44067 & -0.86633 \\
\hline $\mathrm{H}$ & 0.28689 & -1.88111 & -1.63345 \\
\hline $\mathrm{H}$ & 0.89635 & -3.37183 & -2.37067 \\
\hline $\mathrm{H}$ & 6.99981 & -2.50786 & 2.97111 \\
\hline $\mathrm{H}$ & 6.26614 & -3.71359 & 1.87915 \\
\hline $\mathrm{H}$ & 6.90959 & -2.21070 & 1.21561 \\
\hline $\mathrm{H}$ & 1.98601 & -5.29145 & -2.23269 \\
\hline $\mathrm{H}$ & 3.39604 & -5.62619 & -3.28076 \\
\hline $\mathrm{H}$ & 2.31446 & -4.27974 & -3.65151 \\
\hline $\mathrm{H}$ & -6.28673 & 2.11379 & 0.62934 \\
\hline $\mathrm{H}$ & -7.64684 & -2.23475 & 2.61496 \\
\hline $\mathrm{H}$ & -9.06503 & -0.22594 & 2.92428 \\
\hline $\mathrm{H}$ & -8.34980 & 1.95479 & 1.94343 \\
\hline $\mathrm{H}$ & -5.63993 & -3.29589 & 1.71697 \\
\hline $\mathrm{H}$ & -3.28312 & 4.72028 & -2.32731 \\
\hline $\mathrm{H}$ & -6.46407 & 0.20426 & -1.74579 \\
\hline $\mathrm{H}$ & -7.89076 & 1.19478 & -3.47610 \\
\hline $\mathrm{H}$ & -7.32189 & 3.40985 & -4.47517 \\
\hline $\mathrm{H}$ & -5.26868 & 4.59326 & -3.74919 \\
\hline $\mathrm{H}$ & -2.30529 & -5.93720 & -1.66312 \\
\hline
\end{tabular}




\begin{tabular}{|c|c|c|c|}
\hline $\mathrm{H}$ & -1.41524 & -5.63138 & 2.50711 \\
\hline $\mathrm{H}$ & 1.49646 & 5.24180 & -1.85070 \\
\hline $\mathrm{H}$ & -0.53703 & 6.27437 & 1.76682 \\
\hline $\mathrm{H}$ & -3.34166 & 3.89373 & 1.18399 \\
\hline $\mathrm{H}$ & -3.73493 & 6.34246 & 0.93487 \\
\hline $\mathrm{H}$ & -4.19841 & 5.74484 & 2.53990 \\
\hline $\mathrm{H}$ & -2.69951 & 6.65975 & 2.33609 \\
\hline $\mathrm{H}$ & -1.63858 & 2.98554 & 2.72417 \\
\hline $\mathrm{H}$ & -1.35323 & 4.60324 & 3.40345 \\
\hline $\mathrm{H}$ & -2.92545 & 3.81557 & 3.61918 \\
\hline $\mathrm{H}$ & 2.59488 & 6.62008 & -0.16719 \\
\hline $\mathrm{H}$ & 0.90131 & 7.96515 & 2.01213 \\
\hline $\mathrm{H}$ & 2.61615 & 8.21592 & 1.68869 \\
\hline $\mathrm{H}$ & 2.05632 & 6.65391 & 2.30575 \\
\hline $\mathrm{H}$ & 0.32323 & 8.65908 & -0.43165 \\
\hline $\mathrm{H}$ & 2.05269 & 8.99917 & -0.64408 \\
\hline $\mathrm{H}$ & 1.20745 & 7.92321 & -1.77626 \\
\hline $\mathrm{H}$ & -0.95345 & 2.57351 & -2.77019 \\
\hline $\mathrm{H}$ & 1.25061 & 1.89040 & -2.03165 \\
\hline $\mathrm{H}$ & 1.21891 & 2.03298 & -3.79131 \\
\hline $\mathrm{H}$ & 2.02128 & 3.29218 & -2.84072 \\
\hline $\mathrm{H}$ & -1.37735 & 4.72229 & -3.99089 \\
\hline $\mathrm{H}$ & 0.36459 & 5.02339 & -4.07752 \\
\hline $\mathrm{H}$ & -0.33717 & 3.63618 & -4.92893 \\
\hline $\mathrm{H}$ & -0.63049 & -7.44762 & 1.38772 \\
\hline $\mathrm{H}$ & 0.92044 & -6.35522 & -0.21537 \\
\hline $\mathrm{H}$ & -0.03466 & -6.96176 & -1.58202 \\
\hline $\mathrm{H}$ & 0.81580 & -8.09974 & -0.52475 \\
\hline $\mathrm{H}$ & -2.26942 & -8.30309 & -1.06280 \\
\hline $\mathrm{H}$ & -1.33074 & -9.37199 & -0.00820 \\
\hline $\mathrm{H}$ & -2.75143 & -8.51657 & 0.62642 \\
\hline $\mathrm{H}$ & -3.25780 & -2.41768 & 2.95034 \\
\hline $\mathrm{H}$ & -0.81779 & -2.29676 & 2.92878 \\
\hline $\mathrm{H}$ & -1.42113 & -2.46294 & 4.58964 \\
\hline $\mathrm{H}$ & -0.68644 & -3.85693 & 3.78328 \\
\hline $\mathrm{H}$ & -4.49463 & -4.44897 & 3.72369 \\
\hline $\mathrm{H}$ & -2.97775 & -5.16667 & 4.28282 \\
\hline $\mathrm{H}$ & -3.58651 & -3.68796 & 5.04381 \\
\hline $\mathrm{H}$ & -4.35264 & -2.81907 & -1.72690 \\
\hline $\mathrm{H}$ & -5.62590 & -4.95400 & -1.59872 \\
\hline $\mathrm{H}$ & -5.44182 & -4.39321 & -3.27236 \\
\hline $\mathrm{H}$ & -4.45141 & -5.73203 & -2.67075 \\
\hline $\mathrm{H}$ & -2.13835 & -2.66215 & -2.79528 \\
\hline $\mathrm{H}$ & -2.26966 & -4.33739 & -3.38271 \\
\hline $\mathrm{H}$ & -3.38186 & -3.09776 & -3.97981 \\
\hline
\end{tabular}




\section{Examination of other computational methods}

We tested a variety of different functionals commonly deployed in the computational modeling of organic reaction systems. In terms of magnitude and sense of stereoinduction, the $\operatorname{IEFPCM}(1,4-$ dioxane)-B3LYP/6-311+G(d,p)//B3LYP/6-31G(d) recapitulated the experimental results best. Perhaps most notably preliminary calculations with popular functionals shown below predicted the opposite enantiomer to be the major product.

Table S1. Comparison of DFT functionals for single point energy calculations in the gas phase. Relative energies quoted in $\mathrm{kcal} \mathrm{mol}^{-1}$.

\begin{tabular}{ccccc} 
& \multicolumn{4}{c}{ Gas-Phase Derived Relative Free Energies } \\
\cline { 2 - 5 } Transition State & M06-2X/6-31G(d,p) & $\omega B$ B7XD/6-31G(d,p) & B3LYP-D3/6-31G(d,p) & B3LYP/6-311+G(d,p) \\
TS5-E & 0 & 0 & 0 & 0 \\
TS5-Z & 3.3 & 2.7 & 2.4 & 6.5 \\
TS6-E & 0.5 & -0.6 & -0.5 & 4.6 \\
TS6-Z & 2.0 & 2.0 & 1.6 & 1.5 \\
TS7-E & -2.0 & -2.6 & -1.5 & 5.7 \\
TS7-Z & 5.9 & 6.4 & 5.6 & 6 \\
TS8-E & 2.4 & 1.5 & 1.6 & 6.7 \\
TS8-Z & 7.6 & 8.6 & 9.3 & 7.5
\end{tabular}

Table S2. Comparison of DFT functionals for single point energy calculations in the solution phase modeled with IEFPCM(1,4-dioxane). Relative energies quoted in $\mathrm{kcal} \mathrm{mol}^{-1}$.

Solvent Derived Relative Free Energies

$\begin{array}{ccccc}\text { Transition State } & \text { M06-2X/6-31G(d,p) } & \omega B 97 X D / 6-31 \mathrm{G}(\mathrm{d}, \mathrm{p}) & \mathrm{B} 3 \mathrm{LYP}-\mathrm{D} 3 / 6-31 \mathrm{G}(\mathrm{d}, \mathrm{p}) & \mathrm{B} 3 \mathrm{LYP} / 6-311+\mathrm{G}(\mathrm{d}, \mathrm{p}) \\ \text { TS5-E } & 0 & 0 & 0 & 0 \\ \text { TS5-Z } & 3.3 & 2.8 & 2.4 & 6.5 \\ \text { TS6-E } & 0.4 & -0.7 & -0.6 & 4.4 \\ \text { TS6-Z } & 1.6 & 1.6 & 1.3 & 1.2 \\ \text { TS7-E } & -1.7 & -2.4 & -1.3 & 5.9 \\ \text { TS7-Z } & 5 & 5.5 & 4.7 & 5.1 \\ \text { TS8-E } & 2.1 & 1.1 & 1.1 & 6.3 \\ \text { TS8-Z } & 6.4 & 7.5 & 8.2 & 6.4\end{array}$

B3LYP outperforming other modern functionals is uncommon and raised doubts whether this reflected a problem in a different component of the calculation. Using the eight key TS outlined in Table S1 we next assessed the effect of the basis set, solvation model, and entropy contributions to the free energy differences. Unless otherwise noted the following calculations were performed with Gaussian 16 (rev. C.01). 
First, we explored the effects of two different high-quality triple-zeta basis sets along with B3LYP, and three functionals that account for dispersion, M06-2X, ${ }^{8} \omega \mathrm{B} 97 \mathrm{XD},{ }^{14}$ and B3LYP-D3. ${ }^{15}$ The energy difference between the TS leading to competing products decreased for all functionals tested (Table S3 - S6). Similar to the results shown in Tables S1 and S2, B3LYP showed the lowest errors while M06-2X performed the worst.

Table S3. Comparison of DFT functionals with the def2TZVP basis set for single point energy calculations in the gas phase. Relative energies quoted in $\mathrm{kcal} \mathrm{mol}^{-1}$.

Gas-Phase Derived Relative Free Energies

\begin{tabular}{ccccc}
\cline { 2 - 5 } Transition State & M06-2X/def2TZVP & $\omega$ B97XD/def2TZVP & B3LYP-D3/def2TZVP & B3LYP/def2TZVP \\
TS5-E & 0 & 0 & 0 & 0 \\
TS5-Z & 2.8 & 2.4 & 2.6 & 6.3 \\
TS6-E & -0.3 & -1.1 & -0.6 & 4.5 \\
TS6-Z & 1.6 & 1.7 & 1.4 & 1.3 \\
TS7-E & -1.7 & -1.8 & -0.1 & 5.6 \\
TS7-Z & 5.3 & 5.9 & 5.4 & 5.5 \\
TS8-E & 2.1 & 1.5 & 2.1 & 6.6 \\
TS8-Z & 6.6 & 7.6 & 8.4 & 6.8
\end{tabular}

Table S4. Comparison of DFT functionals with the def2TZVP basis set for single point energy calculations in the solution phase modeled with IEFPCM(1,4-dioxane). Relative energies quoted in $\mathrm{kcal} \mathrm{mol}^{-1}$.

Solvent Derived Relative Free Energies

$\begin{array}{ccccc}\text { Transition State } & \text { M06-2X/def2TZVP } & \omega B \text { 97XD/def2TZVP } & \text { B3LYP-D3/def2TZVP } & \text { B3LYP/def2TZVP } \\ \text { TS5-E } & 0 & 0 & 0 & 0 \\ \text { TS5-Z } & 2.8 & 2.4 & 2.5 & 6.2 \\ \text { TS6-E } & -0.5 & -1.3 & -0.8 & 4.4 \\ \text { TS6-Z } & 1.2 & 1.3 & 1.1 & 0.9 \\ \text { TS7-E } & -1.4 & -1.5 & 0.1 & 5.8 \\ \text { TS7-Z } & 4.4 & 5.0 & 4.5 & 4.6 \\ \text { TS8-E } & 1.8 & 1.1 & 1.7 & 6.1 \\ \text { TS8-Z } & 5.5 & 6.6 & 7.3 & 5.7\end{array}$


Table S5. Comparison of DFT functionals with the cc-pVTZ basis set for single point energy calculations in the gas phase. Relative energies quoted in $\mathrm{kcal} \mathrm{mol}^{-1}$.

Gas-Phase Derived Relative Free Energies

$\begin{array}{ccccc}\text { Transition State } & \text { M06-2X/cc-pVTZ } & \omega B \text { 97XD/cc-pVTZ } & \text { B3LYP-D3/cc-pVTZ } & \text { B3LYP/cc-pVTZ } \\ \text { TS5-E } & 0 & 0 & 0 & 0 \\ \text { TS5-Z } & 2.6 & 2.3 & 2.4 & 6.1 \\ \text { TS6-E } & -0.5 & -1.2 & -0.6 & 4.6 \\ \text { TS6-Z } & 1.6 & 1.6 & 1.3 & 1.2 \\ \text { TS7-E } & -1.9 & -2.0 & -0.5 & 5.2 \\ \text { TS7-Z } & 5.2 & 5.9 & 5.3 & 5.4 \\ \text { TS8-E } & 1.9 & 1.3 & 1.8 & 6.3 \\ \text { TS8-Z } & 6.7 & 7.8 & 8.4 & 6.8\end{array}$

Table S6. Comparison of DFT functionals with the cc-pVTZ basis set for single point energy calculations in the solution phase modeled with IEFPCM(1,4-dioxane). Relative energies quoted in $\mathrm{kcal} \mathrm{mol}^{-1}$.

Solvent Derived Relative Free Energies

$\begin{array}{ccccc}\text { Transition State } & \text { M06-2X/cc-pVTZ } & \omega B \text { 97XD/cc-pVTZ } & \text { B3LYP-D3/cc-pVTZ } & \text { B3LYP/cc-pVTZ } \\ \text { TS5-E } & 0 & 0 & 0 & 0 \\ \text { TS5-Z } & 2.6 & 2.3 & 2.3 & 6.0 \\ \text { TS6-E } & -0.6 & -1.3 & -0.7 & 4.4 \\ \text { TS6-Z } & 1.2 & 1.3 & 1.0 & 0.9 \\ \text { TS7-E } & -1.7 & -1.8 & -0.3 & 5.4 \\ \text { TS7-Z } & 4.3 & 5.0 & 4.4 & 4.5 \\ \text { TS8-E } & 1.5 & 0.9 & 1.4 & 5.8 \\ \text { TS8-Z } & 5.6 & 6.7 & 7.3 & 5.8\end{array}$


To investigate the effects of different implicit solvent models on the energies, single point calculations were repeated with a second polarizable continuum model, CPCM, and the universal solvation model (SMD) ${ }^{16}$ using a set of functionals with $6-31 \mathrm{G}(\mathrm{d}, \mathrm{p})$. Likewise, the relative energy differences across the three solvation models did not deviate significantly with $\operatorname{IEFPCM}(1,4-$ dioxane)-B3LYP/6-31G(d,p)//B3LYP/6-31G(d) providing the lowest errors (IEFPCM $=70 \%$ ee, $\mathrm{SMD}=61 \%$ ee, $\mathrm{CPCM}=66 \%$ ee $)$.

Table S7. Comparison of DFT functionals with the 6-31G(d,p) basis set for single point energy calculations in the solution phase modeled with $\operatorname{SMD}(1,4$-dioxane). Relative energies quoted in kcal $\mathrm{mol}^{-1}$.

Solvent Derived Relative Free Energies

$\begin{array}{ccccc}\text { Transition State } & \text { M06-2X/6-31G(d,p) } & \omega B \text { 97XD/6-31G(d,p) } & \text { B3LYP-D3/6-31G(d,p) } & \text { B3LYP/6-31G(d,p) } \\ \text { TS5-E } & 0 & 0 & 0 & 0 \\ \text { TS5-Z } & 3.6 & 3.1 & 2.7 & 6.4 \\ \text { TS6-E } & 0.9 & -0.2 & -0.1 & 5.0 \\ \text { TS6-Z } & 1.4 & 1.4 & 1.1 & 0.9 \\ \text { TS7-E } & -0.9 & -1.5 & -0.4 & 5.3 \\ \text { TS7-Z } & 5.0 & 5.5 & 4.7 & 4.8 \\ \text { TS8-E } & 2.2 & 1.3 & 1.4 & 5.8 \\ \text { TS8-Z } & 6.0 & 7.0 & 7.7 & 6.2\end{array}$

Table S8. Comparison of DFT functionals with the 6-31G(d,p) basis set for single point energy calculations in the solution phase modeled with $\operatorname{CPCM}(1,4$-dioxane). Relative energies quoted in kcal mol-1.

\begin{tabular}{ccccc} 
& \multicolumn{4}{c}{ Solvent Derived Relative Free Energies } \\
\cline { 2 - 5 } Transition State & M06-2X/6-31G(d,p) & $\omega B$ B7XD/6-31G(d,p) & B3LYP-D3/6-31G(d,p) & B3LYP/6-31G(d,p) \\
TS5-E & 0 & 0 & 0 & 0 \\
TS5-Z & 3.1 & 2.6 & 2.2 & 5.9 \\
TS6-E & 0.2 & -0.9 & -0.8 & 4.3 \\
TS6-Z & 1.5 & 1.5 & 1.2 & 1.0 \\
TS7-E & -1.6 & -2.2 & -1.2 & 4.5 \\
TS7-Z & 4.7 & 5.2 & 4.3 & 4.4 \\
TS8-E & 1.8 & 0.8 & 0.9 & 5.4 \\
TS8-Z & 6.3 & 7.3 & 8.1 & 6.5
\end{tabular}


Subsequently, we employed Paton's GoodVibes ${ }^{17}$ to evaluate how applying quasi-rigid rotor-harmonic oscillator (RRHO) corrections change the relative free energies. Tables S9-S12 show that minor changes are observed when utilizing either the Grimme ${ }^{18}$ or Truhlar and Cramer ${ }^{19}$ methods with default settings. While the outcome is slightly improved for the optimal method of $\operatorname{IEFPCM}(1,4-d i o x a n e)-B 3 L Y P / 6-311+G(d, p) / / B 3 L Y P / 6-31 G(d)$, the application does not prove critical. Specifically, the enantioselectivity from this was calculated to be $82 \%$ ee, applying the entropy corrections (Truhlar and Cramer) predicted enantioselectivity to be $85 \%$ ee which was closer to the experimental value of $96 \%$ ee.

Table S9. Comparison of the effects of vibrational entropy treatment using the Grimme method. Different functionals and basis sets were evaluated by means of single point energy calculations in the solution phase modeled with IEFPCM(1,4-dioxane). Relative energies quoted in $\mathrm{kcal} \mathrm{mol}^{-1}$.

Solvent Derived Quasi-RRHO (Grimme) Relative Free Energies

$\begin{array}{ccccc}\text { Transition State } & \text { M06-2X/6-31G(d,p) } & \omega B \text { 97XD/6-31G(d,p) } & \text { B3LYP-D3/6-31G(d,p) } & \text { B3LYP/6-311+G(d,p) } \\ \text { TS5-E } & 0 & 0 & 0 & 0 \\ \text { TS5-Z } & 3.0 & 2.5 & 2.1 & 6.2 \\ \text { TS6-E } & 0.8 & -0.3 & -0.2 & 4.8 \\ \text { TS6-Z } & 1.8 & 1.8 & 1.4 & 1.4 \\ \text { TS7-E } & -1.7 & -2.4 & -1.3 & 5.9 \\ \text { TS7-Z } & 5.1 & 5.6 & 4.8 & 5.3 \\ \text { TS8-E } & 1.9 & 0.9 & 0.9 & 6.1 \\ \text { TS8-Z } & 6.8 & 7.8 & 8.5 & 6.7\end{array}$

Table S10. Comparison of the effects of vibrational entropy treatment using Truhlar and Cramer's method. Different functionals and basis sets were evaluated by means of single point energy calculations in the solution phase modeled with $\operatorname{IEFPCM}(1,4-$ dioxane $)$. Relative energies quoted in $\mathrm{kcal} \mathrm{mol}^{-1}$.

\begin{tabular}{ccccc} 
& \multicolumn{4}{c}{ Solvent Derived Quasi-RRHO (Truhlar and Cramer) Relative Free Energies } \\
\cline { 2 - 5 } Transition State & M06-2X/6-31G(d,p) & $\omega B$ B7XD/6-31G(d,p) & B3LYP-D3/6-31G(d,p) & B3LYP/6-311+G(d,p) \\
TS5-E & 0 & 0 & 0 & 0 \\
TS5-Z & 3.0 & 2.5 & 2.1 & 6.2 \\
TS6-E & 1.1 & 0 & 0.1 & 5.1 \\
TS6-Z & 1.9 & 1.9 & 1.6 & 1.6 \\
TS7-E & -1.7 & -2.3 & -1.2 & 5.9 \\
TS7-Z & 5.5 & 6.0 & 5.2 & 5.7 \\
TS8-E & 1.7 & 0.8 & 0.8 & 6.0 \\
TS8-Z & 7.3 & 8.3 & 9.0 & 7.3
\end{tabular}


Table S11. Comparison of the effects of vibrational entropy treatment using the Grimme method. Different functionals were evaluated by means of single point energy calculations with the def2TZVP basis set in the solution phase modeled with IEFPCM(1,4-dioxane). Relative energies quoted in $\mathrm{kcal} \mathrm{mol}^{-1}$.

Solvent Derived Quasi-RRHO (Grimme) Relative Free Energies

$\begin{array}{ccccc}\text { Transition State } & \text { M06-2X/def2TZVP } & \omega B \text { 97XD/def2TZVP } & \text { B3LYP-D3/def2TZVP } & \text { B3LYP/def2TZVP } \\ \text { TS5-E } & 0 & 0 & 0 & 0 \\ \text { TS5-Z } & 2.5 & 2.1 & 2.3 & 5.9 \\ \text { TS6-E } & -0.1 & -0.9 & -0.4 & 4.7 \\ \text { TS6-Z } & 1.4 & 1.5 & 1.3 & 1.1 \\ \text { TS7-E } & -1.5 & -1.5 & 0 & 5.7 \\ \text { TS7-Z } & 4.5 & 5.1 & 4.6 & 4.7 \\ \text { TS8-E } & 1.6 & 0.9 & 1.5 & 5.9 \\ \text { TS8-Z } & 5.8 & 6.9 & 7.6 & 6.1\end{array}$

Table S12. Comparison of the effects of vibrational entropy treatment using Truhlar and Cramer's method. Different functionals were evaluated by means of single point energy calculations with the def2TZVP basis set in the solution phase modeled with IEFPCM(1,4-dioxane). Relative energies quoted in $\mathrm{kcal} \mathrm{mol}^{-1}$.

Solvent Derived Quasi-RRHO (Truhlar and Cramer) Relative Free Energies

$\begin{array}{ccccc}\text { Transition State } & \text { M06-2X/def2TZVP } & \omega B \text { 97XD/def2TZVP } & \text { B3LYP-D3/def2TZVP } & \text { B3LYP/def2TZVP } \\ \text { TS5-E } & 0 & 0 & 0 & 0 \\ \text { TS5-Z } & 2.5 & 2.1 & 2.3 & 5.9 \\ \text { TS6-E } & 0.2 & -0.6 & -0.1 & 5.0 \\ \text { TS6-Z } & 1.5 & 1.6 & 1.4 & 1.3 \\ \text { TS7-E } & -1.4 & -1.5 & 0.1 & 5.8 \\ \text { TS7-Z } & 4.9 & 5.5 & 5.0 & 5.1 \\ \text { TS8-E } & 1.4 & 0.7 & 1.4 & 5.8 \\ \text { TS8-Z } & 6.3 & 7.4 & 8.2 & 6.6\end{array}$


We also re-evaluated the geometry of the transition state structures by performing a reoptimization at the B3LYP/6-31G(d,p) level of theory. Geometry comparisons quantified by RMSD showed that the structures were unaltered between the two optimization methods. Expectedly, energy evaluation provided similar results to the B3LYP/6-31G(d) optimized system. It should be noted that RMSD was calculated from superimposed structures defined by Atom Specification Language (ASL) as implemented within Maestro.

Table S13. Comparison of DFT functionals with the def2TZVP basis set for single point energy calculations in the gas phase. Geometries optimized at the B3LYP/6-31G(d,p) level. Relative energies quoted in $\mathrm{kcal} \mathrm{mol}^{-1}$.

Gas-Phase Derived Relative Free Energies

$\begin{array}{cccccc}\text { Transition State } & \text { M06-2X/def2TZVP } & \omega B \text { 97XD/def2TZVP } & \text { B3LYP-D3/def2TZVP } & \text { B3LYP/def2TZVP } & \text { RMSD } \\ \text { TS5-E } & 0 & 0 & 0 & 0 & 0.0207 \\ \text { TS5-Z } & 2.8 & 2.5 & 2.6 & 6.2 & 0.0450 \\ \text { TS6-E } & 0.9 & -0.1 & 0.4 & 5.5 & 0.1400 \\ \text { TS6-Z } & 1.6 & 1.7 & 1.4 & 1.2 & 0.0319 \\ \text { TS7-E } & -1.9 & -2.0 & -0.3 & 5.5 & 0.0368 \\ \text { TS7-Z } & 5.4 & 6.1 & 5.4 & 5.5 & 0.1440 \\ \text { TS8-E } & 1.9 & 1.3 & 2.0 & 6.4 & 0.0234 \\ \text { TS8-Z } & 6.6 & 7.8 & 8.5 & 6.6 & 0.0489\end{array}$

Table S14. Comparison of DFT functionals with the def2TZVP basis set for single point energy calculations in the solution phase modeled with IEFPCM(1,4-dioxane). Geometries optimized at the B3LYP/6-31G(d,p) level. Relative energies quoted in $\mathrm{kcal} \mathrm{mol}^{-1}$.

Solvent Derived Relative Free Energies

$\begin{array}{ccccc}\text { Transition State } & \text { M06-2X/def2TZVP } & \omega \text { B97XD/def2TZVP } & \text { B3LYP-D3/def2TZVP } & \text { B3LYP/def2TZVP } \\ \text { TS5-E } & 0 & 0 & 0 & 0 \\ \text { TS5-Z } & 2.7 & 2.4 & 2.5 & 6.0 \\ \text { TS6-E } & 0.7 & -0.3 & 0.1 & 5.2 \\ \text { TS6-Z } & 1.2 & 1.4 & 1.2 & 1.0 \\ \text { TS7-E } & -1.7 & -1.7 & -0.2 & 5.6 \\ \text { TS7-Z } & 4.4 & 5.2 & 4.5 & 4.6 \\ \text { TS8-E } & 1.5 & 0.9 & 1.5 & 5.9 \\ \text { TS8-Z } & 5.5 & 6.7 & 7.4 & 5.5\end{array}$


Table S15. Comparison of DFT functionals with the cc-pVTZ basis set for single point energy calculations in the gas phase. Geometries optimized at the B3LYP/6-31G(d,p) level. Relative energies quoted in $\mathrm{kcal} \mathrm{mol}^{-1}$.

Gas-Phase Derived Relative Free Energies

$\begin{array}{ccccc}\text { Transition State } & \text { M06-2X/cc-pVTZ } & \omega B \text { B7XD/cc-pVTZ } & \text { B3LYP-D3/cc-pVTZ } & \text { B3LYP/cc-pVTZ } \\ \text { TS5-E } & 0 & 0 & 0 & 0 \\ \text { TS5-Z } & 2.6 & 2.4 & 2.4 & 6 \\ \text { TS6-E } & 0.8 & -0.1 & 0.4 & 5.5 \\ \text { TS6-Z } & 1.6 & 1.7 & 1.4 & 1.2 \\ \text { TS7-E } & -2.2 & -2.2 & -0.7 & 5.1 \\ \text { TS7-Z } & 5.3 & 6.1 & 5.4 & 5.4 \\ \text { TS8-E } & 1.7 & 1.1 & 1.7 & 6.1 \\ \text { TS8-Z } & 6.7 & 8.0 & 8.6 & 6.6\end{array}$

Table S16. Comparison of DFT functionals with the cc-pVTZ basis set for single point energy calculations in the solution phase modeled with IEFPCM(1,4-dioxane). Geometries optimized at the B3LYP/6-31G(d,p) level. Relative energies quoted in $\mathrm{kcal} \mathrm{mol}^{-1}$.

Solvent Derived Relative Free Energies

$\begin{array}{ccccc}\text { Transition State } & \text { M06-2X/cc-pVTZ } & \omega B 97 X D / c c-p V T Z & \text { B3LYP-D3/cc-pVTZ } & \text { B3LYP/cc-pVTZ } \\ \text { TS5-E } & 0 & 0 & 0 & 0 \\ \text { TS5-Z } & 2.6 & 2.3 & 2.3 & 5.9 \\ \text { TS6-E } & 0.5 & -0.3 & 0.2 & 5.3 \\ \text { TS6-Z } & 1.2 & 1.4 & 1.1 & 0.9 \\ \text { TS7-E } & -1.9 & -2 & -0.5 & 5.3 \\ \text { TS7-Z } & 4.4 & 5.2 & 4.5 & 4.5 \\ \text { TS8-E } & 1.2 & 0.7 & 1.2 & 5.6 \\ \text { TS8-Z } & 5.6 & 6.8 & 7.5 & 5.5\end{array}$


Given the large system size, we added a long-range D3-dispersion correction to the optimization protocol. RMSD calculations and visual inspection showed that adding this correction leads to some geometry changes, most notably to the H-bonding distances between catalyst and iminium substrate. Overall, the B3LYP-D3/6-31G(d) TS structures appeared more compact with H-bonding contacts being significantly reduced for certain TS pairs. This translated to an energy reordering of the TS with TS6-E and TS8-E now becoming the lowest in energy. When these geometries were evaluated with the following single point energy calculations only very low enantioselectivities or racemic products would be predicted.

Table S17. Comparison of DFT functionals with the 6-31G(d,p) basis set for single point energy calculations in the gas phase. Geometries optimized at the B3LYP-D3/6-31G(d) level. Relative energies quoted in $\mathrm{kcal} \mathrm{mol}^{-1}$. Four lowest highlighted in gray, the two lowest leading to competing products boxed.

\begin{tabular}{ccccc|} 
& \multicolumn{4}{c}{ Gas-Phase Derived Relative Free Energies } \\
\cline { 2 - 5 } Transition State & M06-2X/6-31G(d,p) & (B97XD/6-31G(d,p) B3LYP-D3/6-31G(d,p) & RMSD \\
TS5-E & 0 & 0 & 0 & 0.4957 \\
TS5-Z & 0.2 & 1.0 & 0.9 & 0.7016 \\
\hline TS6-E & -1.3 & -1.6 & -0.9 & 0.6056 \\
\hline TS6-Z & 3.2 & 2.9 & 2.6 & 0.6478 \\
TS7-E & 0 & -0.2 & 0.9 & 0.4957 \\
TS7-Z & 6.1 & 7.0 & 6.1 & 0.5252 \\
\hline TS8-E & -1.1 & -1.8 & -1.0 & 0.6416 \\
\hline TS8-Z & 5 & 4.9 & 5.7 & 0.6708
\end{tabular}

Table S18. Comparison of DFT functionals with the 6-31G(d,p) basis set for single point energy calculations in the solution phase modeled with IEFPCM(1,4-dioxane). Geometries optimized at the B3LYP-D3/6-31G(d) level. Relative energies quoted in $\mathrm{kcal} \mathrm{mol}^{-1}$. Four lowest highlighted in gray, the two lowest leading to competing products boxed.

Solvent Derived Relative Free Energies

\begin{tabular}{|cccc|}
\cline { 2 - 4 } Transition State & M06-2X/6-31G(d,p) $\omega$ B97XD/6-31G(d,p) & B 3LYP-D3/6-31G(d,p) \\
TS5-E & 0 & 0 & 0 \\
\hline TS5-Z & 0.3 & 1.1 & 0.9 \\
\hline TS6-E & -1.7 & -2.0 & -1.3 \\
\hline TS6-Z & 3.3 & 2.9 & 2.5 \\
TS7-E & 0.2 & 0 & 1.0 \\
\hline TS7-Z & 5.5 & 6.3 & 5.3 \\
\hline TS8-E & -1.4 & -2.0 & -1.3 \\
\hline TS8-Z & 4.7 & 4.6 & 5.5 \\
\hline
\end{tabular}


Perhaps unsurprisingly the energy reordering could be linked to significant geometric changes in how the iminium fits inside the chiral pocket. In the superimposed structures of TS6-E and TS8E, they are both significantly closer in space to the aromatic catalyst substituent. This should lead to increased attractive contacts between substrate and catalyst. Ultimately, resulting in these TS becoming lower in energy relative to the others which do not experience significant increases in attractive contacts (e.g. TS7-E and TS5-E).

A. Low energy TS that experienced large structural changes

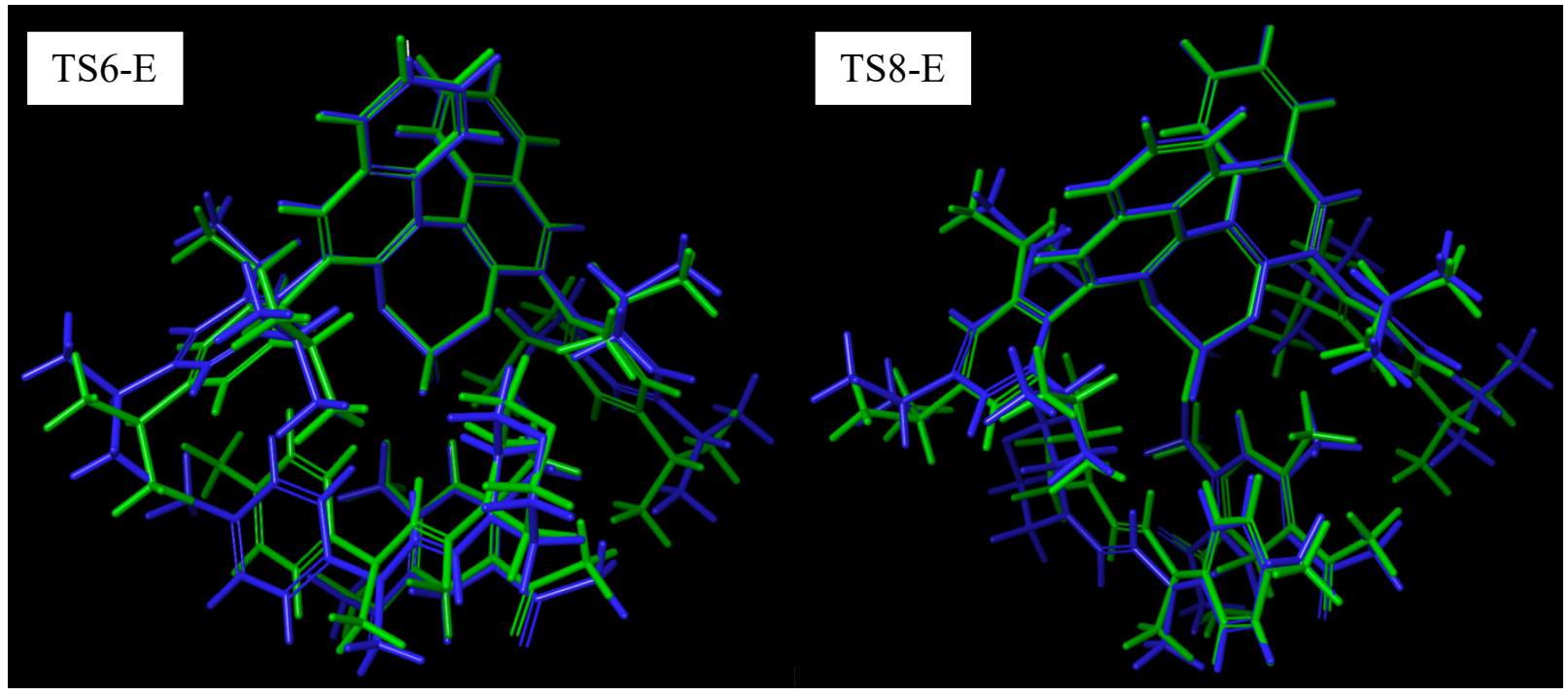

B. Low energy TS that experienced minor structural changes

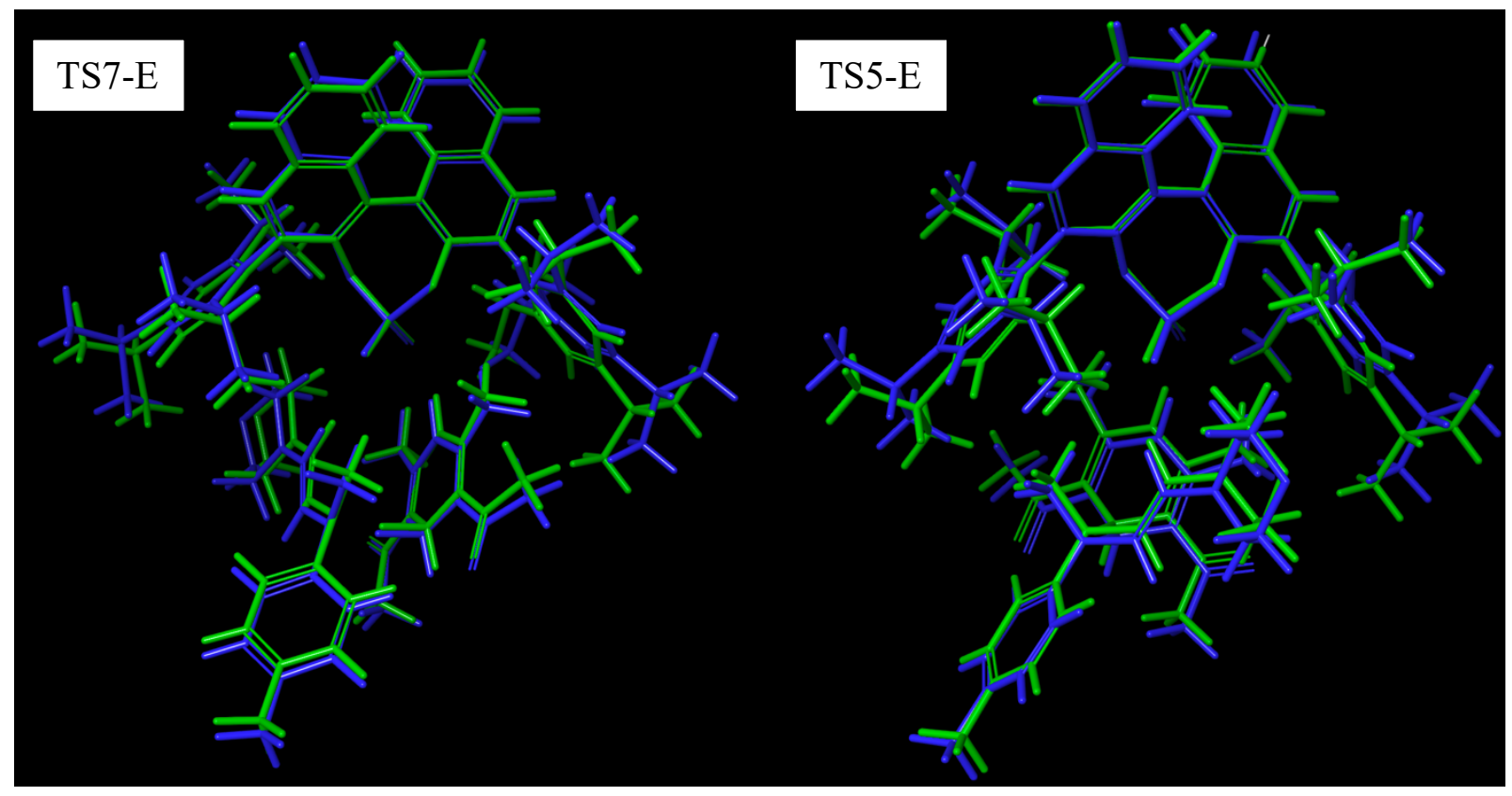

Figure S1. Mapping changes in B3LYP/6-31G(d) and B3LYP-D3/6-31G(d) for the four TS pairs that are lowest in energy. B3LYP/6-31G(d) geometries in blue and B3LYP-D3/6-31G(d) in green. 
To determine if this observation was consistent with other dispersion correcting functionals we reoptimized the key TS with M06-2X/6-31G(d) and the resulting structures were re-evaluated with single-point energy calculations using a set of computational conditions. Indeed, these methods also predicted low levels of enantioselectivity. Similar to the B3LYP-D3/6-31G(d) optimized TS structures, TS6-E, TS7-E and TS8-E are the lowest in energy.

Table S19. Comparison of DFT functionals with the 6-31G(d,p) basis set for single point energy calculations in the gas phase. Geometries optimized at the M06-2X/6-31G(d) level. Relative energies quoted in $\mathrm{kcal} \mathrm{mol}^{-1}$. Four lowest highlighted in gray, the two lowest leading to competing products boxed (functional dependent).

Gas-Phase Derived Relative Free Energies

\begin{tabular}{|ccccc|}
\cline { 2 - 5 } Transition State & M06-2X/6-31G(d,p) $\omega$ B97XD/6-31G(d,p) & B3LYP-D3/6-31G(d,p) & RMSD \\
TS5-E & 0 & 0 & 0 & 0.4708 \\
TS5-Z & 2.6 & 2.7 & 2.9 & 0.7281 \\
\hline TS6-E & 0.2 & -0.6 & 0.2 & 0.7429 \\
\hline TS6-Z & 3.1 & 3.1 & 2.1 & 0.7150 \\
\hline TS7-E & -1.3 & -1.2 & -0.4 & 0.5560 \\
\hline TS7-Z & 1.6 & 1.8 & 1.5 & 1.1229 \\
\hline TS8-E & -0.4 & -0.8 & -0.1 & 0.7994 \\
\hline TS8-Z & 3.8 & 4.6 & 5.5 & 0.7044
\end{tabular}

Table S20. Comparison of DFT functionals with the 6-31G(d,p) basis set for single point energy calculations in the solution phase modeled with IEFPCM(1,4-dioxane). Geometries optimized at the M06-2X/6-31G(d) level. Relative energies quoted in $\mathrm{kcal} \mathrm{mol}^{-1}$. Four lowest highlighted in gray, the two lowest leading to competing products boxed (functional dependent).

Solvent Derived Relative Free Energies

\begin{tabular}{|cccc|}
\cline { 2 - 4 } Transition State & M06-2X/6-31G(d,p) & $\omega B$ B7XD/6-31G(d,p) & B3LYP-D3/6-31G(d,p) \\
TS5-E & 0 & 0 & 0 \\
TS5-Z & 2.5 & 2.6 & 2.7 \\
\hline TS6-E & -0.2 & -1.0 & -0.3 \\
\hline TS6-Z & 3.0 & 3.0 & 2.1 \\
\hline TS7-E & -1.0 & -0.9 & -0.2 \\
\hline TS7-Z & 1.8 & 2.0 & 1.7 \\
\hline TS8-E & -0.8 & -1.2 & -0.4 \\
\hline TS8-Z & 3.6 & 4.4 & 5.3 \\
\hline
\end{tabular}


A. Low energy TS that experienced large structural changes

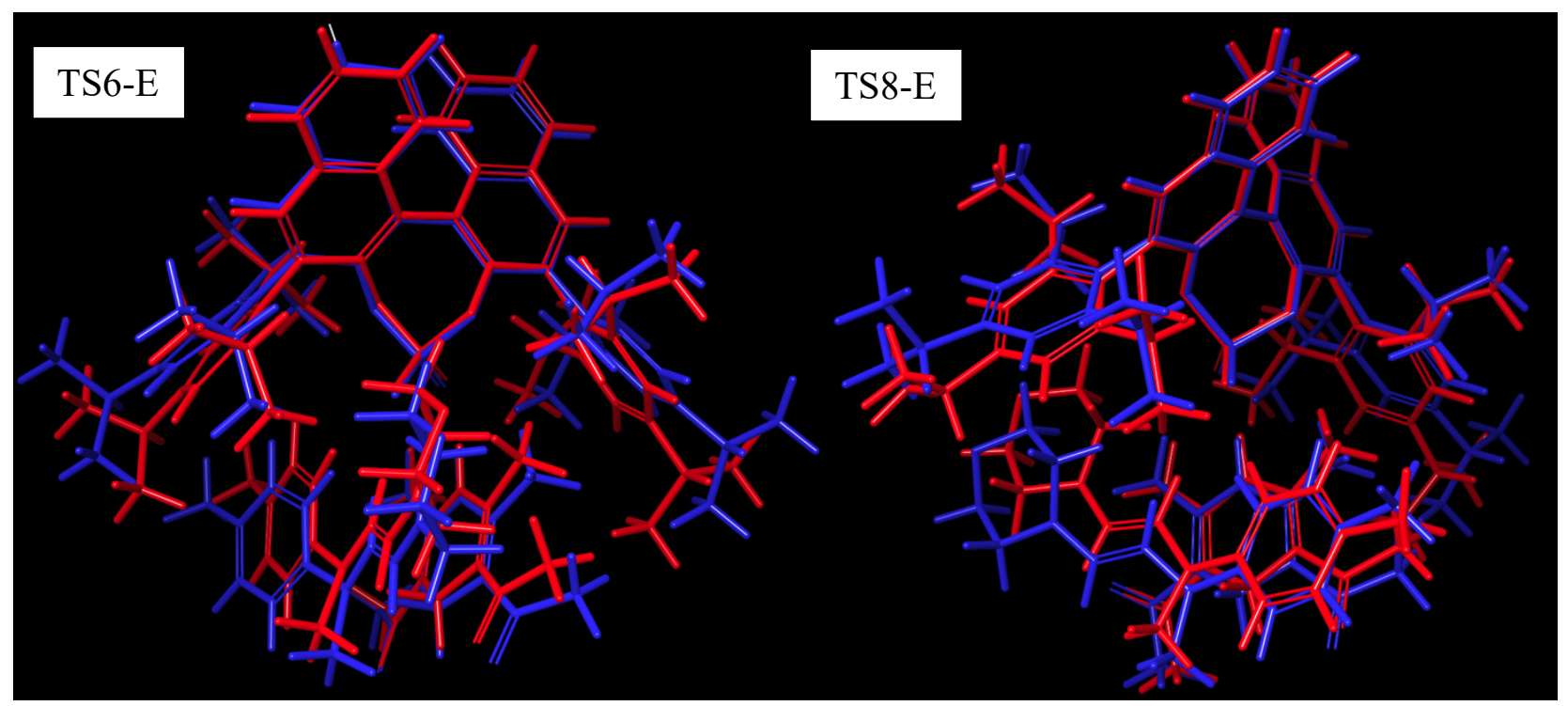

B. Low energy TS that experienced minor structural changes

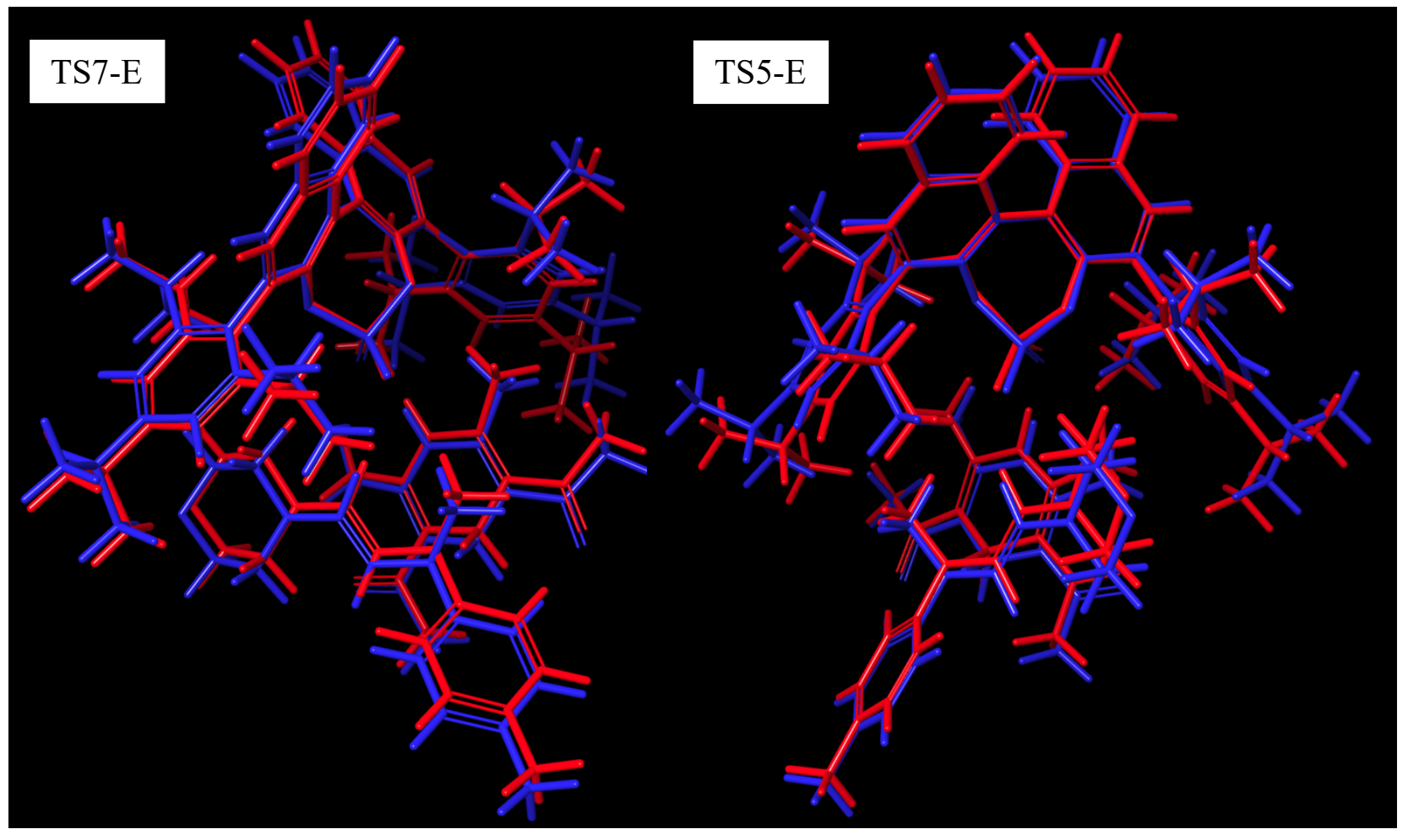

Figure S2. Mapping changes in B3LYP/6-31G(d) and M06-2X/6-31G(d) for the four TS pairs that are lowest in energy. B3LYP/6-31G(d) geometries in blue and M06-2X/6-31G(d) in red. 
To explore the effect of alternative treatment of electron correlation, single-point energy calculations were performed using DLPNO-CCSD(T) as implemented within Orca (version 4.2.1). ${ }^{20}$ These methods also did not reproduce the experimental result, predicting low selectivities.

Table S21. DLPNO-CCSD(T)/cc-pVTZ energies and derived free energies in CPCM dioxane. These were calculated on structures optimized at the B3LYP/6-31G(d) level. Relative energies quoted in kcal $\mathrm{mol}^{-1}$.

\begin{tabular}{ccc} 
Transition State & DLPNO-CCSD(T)/cc-pVTZ Energies & DLPNO-CCSD(T)/cc-pVTZ Derived Free Energies \\
\hline TS5-E & 0 & 0 \\
TS5-Z & 3.4 & 3.6 \\
TS6-E & -0.8 & -1.5 \\
TS6-Z & 2.8 & 1.8 \\
TS7-E & -1.1 & -1.0 \\
TS7-Z & 5.3 & 4.6 \\
TS8-E & 0.8 & 1.1 \\
TS8-Z & 6.8 & 5.9
\end{tabular}

Because the computational treatment of DLPNO-CCSD $(\mathrm{T}) / \mathrm{cc}-\mathrm{pVTZ}$ correlates closely with "gold standard" CCSD(T) methods, ${ }^{21}$ we suggest that the differences between experiment and theory are likely not a result of failure in electronic structure theory but, by deduction arise from challenges associated in describing large systems in solution. One of the challenges is that favorable interactions can usually also form with the solvent and so an attractive interaction is not, in itself, important, unless it is stronger than the alternative solvent interactions. Consequently, modern density functionals can overestimate attractive contacts between molecules when evaluated in the absence of explicit solvent molecules. In other words, the B3LYP geometries and energies may more closely resemble the experimental conditions in which dispersion forces are diminished by competitive interactions with the solvent. ${ }^{22}$ Specifically, for this reaction system these are C-H $\pi$ contacts between the iminium substrates and the catalyst aromatic substituent. Modern density functionals overvalue these contacts in the single point energy evaluation but this is strengthened when combined with geometries that are optimized with dispersion correcting functionals. Our findings are in agreement with previous reports that show that simple B3LYP works better for other chemical systems than modern functionals for similar reasons. ${ }^{22-24}$ We suggest based on this computational data and conclusions from other investigations, that modern dispersion containing functionals account for attractive contacts that are likely to be disrupted by explicit solvent molecules under the reaction conditions. Thereby, accounting for contacts that are not important in determining selectivity in this reaction and leading to errors in correlating computation to experiment. Considering this and the reported failures of B3LYP, ${ }^{25}$ illustrates the need to perform DFT calibrations for each specific chemical system. 
Cartesian coordinates and energies of the re-optimized TS

TS5-E

B3LYP/6-31G(d,p) Energy = -3928.597836

B3LYP/6-31G(d,p) Free Energy = -3927.224911

Number of Imaginary Frequencies $=1$ (-1004.47)

B3LYP/6-31G(d,p) Geometry

C $\quad 4.10660 \quad 1.41016$

$\begin{array}{llll}\mathrm{C} & 4.75082 & 0.40528 & 0.57297\end{array}$

$\begin{array}{llll}\mathrm{C} & 2.75556 & 1.44956 & 1.67375\end{array}$

$\begin{array}{llll}\text { C } & 6.24582 & 0.29102 & 0.76045\end{array}$

$\begin{array}{llll}\mathrm{C} & 4.05357 & -0.92742 & 0.31662\end{array}$

$\begin{array}{llll}\text { C } & 7.09405 & -0.11850 & -0.28182\end{array}$

$\begin{array}{llll}\text { C } & 8.46214 & -0.26738 & -0.07019\end{array}$

$\begin{array}{llll}\text { C } & 9.04128 & -0.02336 & 1.18267\end{array}$

$\begin{array}{llll}\text { C } & 8.19368 & 0.37312 & 2.22280\end{array}$

$\begin{array}{llll}\text { C } & 6.82381 & 0.53119 & 2.01789\end{array}$

$\begin{array}{llll}\mathrm{C} & 10.52965 & -0.16295 & 1.39309\end{array}$

$\begin{array}{llll}\mathrm{N} & 2.12614 & 2.37293 & 2.41963\end{array}$

$\begin{array}{llll}\mathrm{C} & 2.77216 & 3.50514 & 3.08823\end{array}$

$\begin{array}{llll}\mathrm{C} & 2.55676 & 3.38941 & 4.60237\end{array}$

$\begin{array}{llll}\text { O } & 1.17954 & 3.29274 & 4.92212\end{array}$

$\begin{array}{llll}\mathrm{C} & 0.57813 & 2.15991 & 4.30001\end{array}$

$\begin{array}{llll}\mathrm{C} & 0.70574 & 2.23253 & 2.77792\end{array}$

$\begin{array}{llll}\mathrm{H} & 2.08244 & 0.67867 & 1.30369\end{array}$

$\begin{array}{llll}\mathrm{C} & 4.30737 & 1.49316 & -1.88690\end{array}$

$\begin{array}{llll}\text { C } & 3.44204 & 2.58040 & -1.44065\end{array}$

$\begin{array}{llll}\mathrm{C} & 2.06784 & 2.37770 & -1.48455\end{array}$

$\begin{array}{llll}\mathrm{N} & 1.58730 & 1.23796 & -2.05756\end{array}$

$\begin{array}{llll}\mathrm{C} & 2.33867 & 0.32343 & -2.74733\end{array}$

$\begin{array}{llll}\text { C } & 3.71355 & 0.47254 & -2.76107\end{array}$

C $\quad 1.51484 \quad-0.75084 \quad-3.41091$

$\begin{array}{llll}\mathrm{C} & 1.01634 & 3.32382 & -0.98446\end{array}$

$\begin{array}{llll}\text { C } & 4.67842 & -0.32571 & -3.55739\end{array}$

$\begin{array}{llll}\text { C } & 4.02603 & 3.82428 & -0.87631\end{array}$

$\begin{array}{llll}\text { C } & 4.24869 & -1.23793 & -4.69280\end{array}$

$\begin{array}{llll}\mathrm{O} & 5.88193 & -0.21463 & -3.32121\end{array}$

$\begin{array}{llll}\text { C } & 5.53461 & 4.00913 & -0.96703\end{array}$

$\begin{array}{llll}\mathrm{O} & 3.33837 & 4.70240 & -0.36076\end{array}$

$\begin{array}{llll}\text { C } & -6.17779 & -2.38674 & -0.97571\end{array}$

$\begin{array}{llll}\text { C } & -5.56566 & -1.12266 & -0.74791\end{array}$

$\begin{array}{llll}\text { C } & -6.22132 & 0.04098 & -1.26313\end{array}$

$\begin{array}{llll}\text { C } & -7.47098 & -0.09403 & -1.92595\end{array}$

$\begin{array}{llll}\text { C } & -8.04473 & -1.33023 & -2.10952\end{array}$

$\begin{array}{llll}\text { C } & -7.38042 & -2.48704 & -1.63950\end{array}$ 


\begin{tabular}{|c|c|c|c|}
\hline $\mathrm{C}$ & -4.31076 & -0.96769 & -0.06046 \\
\hline $\mathrm{C}$ & -3.70481 & 0.28192 & -0.05943 \\
\hline $\mathrm{C}$ & -4.34853 & 1.45428 & -0.55983 \\
\hline $\mathrm{C}$ & -5.60173 & 1.30705 & -1.11670 \\
\hline $\mathrm{C}$ & -3.65589 & -2.12037 & 0.62272 \\
\hline $\mathrm{C}$ & -4.34645 & -2.88255 & 1.62924 \\
\hline $\mathrm{C}$ & -3.73680 & -4.07402 & 2.13785 \\
\hline $\mathrm{C}$ & -2.45451 & -4.45077 & 1.66635 \\
\hline $\mathrm{C}$ & -1.73489 & -3.66795 & 0.78798 \\
\hline $\mathrm{C}$ & -2.35234 & -2.47655 & 0.29992 \\
\hline $\mathrm{C}$ & -5.60147 & -2.49247 & 2.17459 \\
\hline $\mathrm{C}$ & -6.22793 & -3.25308 & 3.13685 \\
\hline $\mathrm{C}$ & -5.64037 & -4.45106 & 3.60618 \\
\hline $\mathrm{C}$ & -4.41799 & -4.84725 & 3.11628 \\
\hline $\mathrm{C}$ & -3.71942 & 2.81265 & -0.45738 \\
\hline $\mathrm{O}$ & -1.64835 & -1.71349 & -0.61106 \\
\hline $\mathrm{O}$ & -2.46164 & 0.42327 & 0.53235 \\
\hline $\mathrm{C}$ & -0.36154 & -4.08189 & 0.34990 \\
\hline $\mathrm{C}$ & -3.64999 & 3.46123 & 0.79707 \\
\hline $\mathrm{C}$ & -3.09455 & 4.74410 & 0.86830 \\
\hline $\mathrm{C}$ & -2.62390 & 5.41826 & -0.25919 \\
\hline $\mathrm{C}$ & -2.71882 & 4.76477 & -1.49107 \\
\hline $\mathrm{C}$ & -3.25433 & 3.47765 & -1.61935 \\
\hline $\mathrm{C}$ & 0.72126 & -4.02903 & 1.25798 \\
\hline $\mathrm{C}$ & 1.98392 & -4.45743 & 0.82681 \\
\hline $\mathrm{C}$ & 2.21257 & -4.93869 & -0.46211 \\
\hline $\mathrm{C}$ & 1.12411 & -4.99149 & -1.33796 \\
\hline $\mathrm{C}$ & -0.15692 & -4.57853 & -0.96045 \\
\hline $\mathrm{P}$ & -1.11897 & -0.18904 & -0.22389 \\
\hline $\mathrm{O}$ & -0.01539 & -0.19885 & 0.79174 \\
\hline $\mathrm{O}$ & -0.91328 & 0.48702 & -1.56493 \\
\hline $\mathrm{C}$ & -1.30184 & -4.73766 & -1.96104 \\
\hline $\mathrm{C}$ & -1.55235 & -6.22318 & -2.28780 \\
\hline $\mathrm{C}$ & -1.07796 & -3.91596 & -3.24314 \\
\hline $\mathrm{C}$ & 3.59525 & -5.42428 & -0.87858 \\
\hline $\mathrm{C}$ & 4.13319 & -4.67632 & -2.11199 \\
\hline $\mathrm{C}$ & 3.61449 & -6.94738 & -1.11027 \\
\hline $\mathrm{C}$ & 0.56778 & -3.54630 & 2.70106 \\
\hline $\mathrm{C}$ & 1.48514 & -2.35248 & 3.01956 \\
\hline $\mathrm{C}$ & 0.78831 & -4.69754 & 3.70179 \\
\hline $\mathrm{C}$ & -2.07733 & 6.83621 & -0.14464 \\
\hline $\mathrm{C}$ & -3.00888 & 7.85320 & -0.83226 \\
\hline $\mathrm{C}$ & -0.63878 & 6.96426 & -0.67673 \\
\hline $\mathrm{C}$ & -3.36255 & 2.86657 & -3.01837 \\
\hline $\mathrm{C}$ & -2.02064 & 2.84238 & -3.77123 \\
\hline $\mathrm{C}$ & -4.43849 & 3.59249 & -3.85136 \\
\hline
\end{tabular}




\begin{tabular}{|c|c|c|c|}
\hline $\mathrm{C}$ & -4.21812 & 2.83798 & 2.07200 \\
\hline $\mathrm{C}$ & -5.38629 & 3.67372 & 2.63106 \\
\hline $\mathrm{C}$ & -3.13517 & 2.61014 & 3.14171 \\
\hline $\mathrm{H}$ & 4.74575 & 2.21304 & 1.71918 \\
\hline $\mathrm{H}$ & 4.13449 & -1.55583 & 1.20972 \\
\hline $\mathrm{H}$ & 4.53963 & -1.46209 & -0.50340 \\
\hline $\mathrm{H}$ & 2.99343 & -0.81881 & 0.07846 \\
\hline $\mathrm{H}$ & 6.69148 & -0.29744 & -1.27397 \\
\hline $\mathrm{H}$ & 9.09298 & -0.57666 & -0.89997 \\
\hline $\mathrm{H}$ & 8.60746 & 0.55442 & 3.21177 \\
\hline $\mathrm{H}$ & 6.19039 & 0.81322 & 2.85294 \\
\hline $\mathrm{H}$ & 10.77389 & -0.30010 & 2.45031 \\
\hline $\mathrm{H}$ & 11.06409 & 0.73046 & 1.04668 \\
\hline $\mathrm{H}$ & 10.93393 & -1.01495 & 0.83769 \\
\hline $\mathrm{H}$ & 2.31621 & 4.43043 & 2.71809 \\
\hline $\mathrm{H}$ & 3.83478 & 3.53870 & 2.85238 \\
\hline $\mathrm{H}$ & 3.10458 & 2.51130 & 4.98312 \\
\hline $\mathrm{H}$ & 2.93716 & 4.28266 & 5.10616 \\
\hline $\mathrm{H}$ & 1.04262 & 1.23107 & 4.66854 \\
\hline $\mathrm{H}$ & -0.47451 & 2.16493 & 4.59161 \\
\hline $\mathrm{H}$ & 0.16604 & 3.11601 & 2.41465 \\
\hline $\mathrm{H}$ & 0.29342 & 1.34619 & 2.28796 \\
\hline $\mathrm{H}$ & 4.64430 & 0.90993 & -0.73412 \\
\hline $\mathrm{H}$ & 5.32257 & 1.75493 & -2.17774 \\
\hline $\mathrm{H}$ & 0.56517 & 1.00682 & -1.90609 \\
\hline $\mathrm{H}$ & 1.92930 & -1.74378 & -3.23190 \\
\hline $\mathrm{H}$ & 0.49704 & -0.72695 & -3.01812 \\
\hline $\mathrm{H}$ & 1.45997 & -0.59582 & -4.49310 \\
\hline $\mathrm{H}$ & 0.02176 & 2.89202 & -1.09829 \\
\hline $\mathrm{H}$ & 1.19901 & 3.58039 & 0.05924 \\
\hline $\mathrm{H}$ & 1.06981 & 4.26795 & -1.53310 \\
\hline $\mathrm{H}$ & 5.14337 & -1.49401 & -5.26142 \\
\hline $\mathrm{H}$ & 3.80697 & -2.16311 & -4.30914 \\
\hline $\mathrm{H}$ & 3.51423 & -0.76830 & -5.35178 \\
\hline $\mathrm{H}$ & 5.78905 & 4.96267 & -0.50357 \\
\hline $\mathrm{H}$ & 5.86523 & 4.01863 & -2.01219 \\
\hline $\mathrm{H}$ & 6.07950 & 3.20252 & -0.46579 \\
\hline $\mathrm{H}$ & -5.67945 & -3.28432 & -0.63064 \\
\hline $\mathrm{H}$ & -7.95843 & 0.80291 & -2.29923 \\
\hline $\mathrm{H}$ & -8.99642 & -1.42264 & -2.62439 \\
\hline $\mathrm{H}$ & -7.82048 & -3.46568 & -1.80781 \\
\hline $\mathrm{H}$ & -6.12617 & 2.18716 & -1.47791 \\
\hline $\mathrm{H}$ & -2.01605 & -5.37532 & 2.03192 \\
\hline $\mathrm{H}$ & -6.06222 & -1.57363 & 1.83291 \\
\hline $\mathrm{H}$ & -7.18103 & -2.92658 & 3.54267 \\
\hline $\mathrm{H}$ & -6.14869 & -5.04572 & 4.35940 \\
\hline
\end{tabular}




\begin{tabular}{|c|c|c|c|}
\hline $\mathrm{H}$ & -3.94374 & -5.75474 & 3.48104 \\
\hline $\mathrm{H}$ & -3.04731 & 5.24561 & 1.83233 \\
\hline $\mathrm{H}$ & -2.37645 & 5.27610 & -2.38677 \\
\hline $\mathrm{H}$ & 2.81738 & -4.42279 & 1.52466 \\
\hline $\mathrm{H}$ & 1.26984 & -5.38426 & -2.34109 \\
\hline $\mathrm{H}$ & -2.21428 & -4.35810 & -1.49485 \\
\hline $\mathrm{H}$ & -1.75395 & -6.79978 & -1.37946 \\
\hline $\mathrm{H}$ & -2.41440 & -6.32884 & -2.95576 \\
\hline $\mathrm{H}$ & -0.68868 & -6.67787 & -2.78543 \\
\hline $\mathrm{H}$ & -0.97430 & -2.85451 & -3.00538 \\
\hline $\mathrm{H}$ & -0.18112 & -4.24319 & -3.78184 \\
\hline $\mathrm{H}$ & -1.92972 & -4.03021 & -3.92278 \\
\hline $\mathrm{H}$ & 4.27586 & -5.21032 & -0.04391 \\
\hline $\mathrm{H}$ & 4.15514 & -3.59539 & -1.93852 \\
\hline $\mathrm{H}$ & 5.15144 & -5.00146 & -2.35130 \\
\hline $\mathrm{H}$ & 3.51062 & -4.86419 & -2.99403 \\
\hline $\mathrm{H}$ & 3.27349 & -7.48532 & -0.22056 \\
\hline $\mathrm{H}$ & 2.95784 & -7.22881 & -1.94076 \\
\hline $\mathrm{H}$ & 4.62601 & -7.29241 & -1.35200 \\
\hline $\mathrm{H}$ & -0.45797 & -3.19398 & 2.82966 \\
\hline $\mathrm{H}$ & 1.26889 & -1.52602 & 2.33911 \\
\hline $\mathrm{H}$ & 1.31493 & -2.01235 & 4.04810 \\
\hline $\mathrm{H}$ & 2.54512 & -2.61887 & 2.93590 \\
\hline $\mathrm{H}$ & 0.10434 & -5.53132 & 3.51304 \\
\hline $\mathrm{H}$ & 1.80976 & -5.08968 & 3.64237 \\
\hline $\mathrm{H}$ & 0.62403 & -4.35105 & 4.72825 \\
\hline $\mathrm{H}$ & -2.05469 & 7.08440 & 0.92493 \\
\hline $\mathrm{H}$ & -4.02422 & 7.79523 & -0.42821 \\
\hline $\mathrm{H}$ & -3.06874 & 7.66732 & -1.91026 \\
\hline $\mathrm{H}$ & -2.64155 & 8.87564 & -0.68971 \\
\hline $\mathrm{H}$ & -0.58834 & 6.73999 & -1.74795 \\
\hline $\mathrm{H}$ & -0.26516 & 7.98465 & -0.53730 \\
\hline $\mathrm{H}$ & 0.04287 & 6.28220 & -0.15985 \\
\hline $\mathrm{H}$ & -3.67600 & 1.82615 & -2.90681 \\
\hline $\mathrm{H}$ & -1.29183 & 2.24272 & -3.22365 \\
\hline $\mathrm{H}$ & -2.15695 & 2.39130 & -4.76077 \\
\hline $\mathrm{H}$ & -1.61407 & 3.84822 & -3.92502 \\
\hline $\mathrm{H}$ & -5.41304 & 3.57927 & -3.35333 \\
\hline $\mathrm{H}$ & -4.16950 & 4.64149 & -4.01917 \\
\hline $\mathrm{H}$ & -4.55311 & 3.11602 & -4.83140 \\
\hline $\mathrm{H}$ & -4.62510 & 1.85652 & 1.81670 \\
\hline $\mathrm{H}$ & -6.17408 & 3.80241 & 1.88211 \\
\hline $\mathrm{H}$ & -5.82581 & 3.18090 & 3.50540 \\
\hline $\mathrm{H}$ & -5.05714 & 4.67095 & 2.94258 \\
\hline $\mathrm{H}$ & -2.35363 & 1.95255 & 2.75299 \\
\hline $\mathrm{H}$ & -2.67658 & 3.55415 & 3.45803 \\
\hline
\end{tabular}


$\begin{array}{llll}\mathrm{H} & -3.56918 & 2.13862 & 4.03073\end{array}$

TS5-Z

B3LYP/6-31G(d,p) Energy $=-3928.588470$

B3LYP/6-31G(d,p) Free Energy = -3927.215388

Number of Imaginary Frequencies $=1$ (-909.43)

$\begin{array}{lccc}\text { B3LYP/6-31G(d,p) } & \text { Geometry } & \\ \mathrm{C} & -3.93554 & -2.24622 & 2.44607 \\ \mathrm{C} & -5.04471 & -2.06121 & 1.54077 \\ \mathrm{C} & -2.92904 & -1.34293 & 2.72268 \\ \mathrm{~N} & -1.92442 & -1.48419 & 3.60747 \\ \mathrm{C} & -1.78914 & -2.60899 & 4.53267 \\ \mathrm{C} & -0.32075 & -3.03335 & 4.63520 \\ \mathrm{O} & 0.51990 & -1.94675 & 4.96645 \\ \mathrm{C} & 0.43364 & -0.91475 & 3.98215 \\ \mathrm{C} & -0.98896 & -0.37718 & 3.86348 \\ \mathrm{H} & -2.90264 & -0.38990 & 2.20826 \\ \mathrm{C} & -4.12259 & -3.36312 & -0.67369 \\ \mathrm{C} & -2.83205 & -3.83588 & -0.16211 \\ \mathrm{C} & -1.69729 & -3.10734 & -0.48227 \\ \mathrm{~N} & -1.80810 & -2.07845 & -1.37437 \\ \mathrm{C} & -2.92553 & -1.79060 & -2.11098 \\ \mathrm{C} & -4.09885 & -2.47646 & -1.83859 \\ \mathrm{C} & -2.72622 & -0.73510 & -3.16022 \\ \mathrm{C} & -0.30449 & -3.30681 & 0.05002 \\ \mathrm{C} & -5.31119 & -2.28182 & -2.67508 \\ \mathrm{C} & -2.91119 & -5.01911 & 0.72996 \\ \mathrm{C} & -6.59221 & -2.99489 & -2.26829 \\ \mathrm{O} & -5.30485 & -1.57787 & -3.67955 \\ \mathrm{C} & -1.68679 & -5.80067 & 1.17437 \\ \mathrm{O} & -4.01959 & -5.41313 & 1.09613 \\ \mathrm{C} & 4.71810 & 2.65903 & 2.52306 \\ \mathrm{C} & 3.54419 & 3.05311 & 1.82344 \\ \mathrm{C} & 2.86941 & 4.24033 & 2.25289 \\ \mathrm{C} & 3.40861 & 5.00012 & 3.32579 \\ \mathrm{C} & 4.55244 & 4.59595 & 3.97432 \\ \mathrm{C} & 5.20494 & 3.40671 & 3.57239 \\ \mathrm{C} & 2.99493 & 2.29819 & 0.73091 \\ \mathrm{C} & 1.73788 & 2.64421 & 0.25262 \\ \mathrm{C} & 1.08527 & 3.86073 & 0.61586 \\ \mathrm{C} & 1.68153 & 4.63763 & 1.58871 \\ \mathrm{C} & 3.76538 & 1.21137 & 0.06180 \\ \mathrm{C} & 5.06043 & 1.49029 & -0.50381 \\ & 5.81280 & 0.41524 & -1.07346 \\ & 5.23970 & -0.87824 & -1.11416\end{array}$




\begin{tabular}{|c|c|c|c|}
\hline $\mathrm{C}$ & 3.95795 & -1.13713 & -0.67282 \\
\hline $\mathrm{C}$ & 3.22152 & -0.05938 & -0.09097 \\
\hline $\mathrm{C}$ & 5.62630 & 2.79563 & -0.56211 \\
\hline $\mathrm{C}$ & 6.87184 & 3.00988 & -1.10933 \\
\hline $\mathrm{C}$ & 7.62933 & 1.93449 & -1.62901 \\
\hline $\mathrm{C}$ & 7.10307 & 0.66458 & -1.61396 \\
\hline $\mathrm{C}$ & -0.15910 & 4.33679 & -0.07309 \\
\hline $\mathrm{O}$ & 1.96626 & -0.32266 & 0.42216 \\
\hline $\mathrm{O}$ & 1.13649 & 1.83898 & -0.69519 \\
\hline $\mathrm{C}$ & 3.43242 & -2.53753 & -0.82009 \\
\hline $\mathrm{C}$ & -1.37140 & 4.46575 & 0.64322 \\
\hline $\mathrm{C}$ & -2.49101 & 5.00032 & -0.00929 \\
\hline $\mathrm{C}$ & -2.45587 & 5.41115 & -1.34163 \\
\hline $\mathrm{C}$ & -1.24968 & 5.26514 & -2.03149 \\
\hline $\mathrm{C}$ & -0.10194 & 4.74138 & -1.43114 \\
\hline $\mathrm{C}$ & 3.02690 & -3.00630 & -2.09298 \\
\hline $\mathrm{C}$ & 2.70587 & -4.36124 & -2.24314 \\
\hline $\mathrm{C}$ & 2.76781 & -5.26609 & -1.18097 \\
\hline $\mathrm{C}$ & 3.14621 & -4.77350 & 0.07115 \\
\hline $\mathrm{C}$ & 3.48238 & -3.43003 & 0.27596 \\
\hline $\mathrm{P}$ & 0.58033 & 0.34408 & -0.23594 \\
\hline $\mathrm{O}$ & 0.25533 & -0.36503 & -1.53374 \\
\hline $\mathrm{O}$ & -0.42507 & 0.40397 & 0.87306 \\
\hline $\mathrm{C}$ & 3.97405 & -2.97639 & 1.65027 \\
\hline $\mathrm{C}$ & 5.47245 & -3.29552 & 1.82685 \\
\hline $\mathrm{C}$ & 3.15743 & -3.56216 & 2.81383 \\
\hline $\mathrm{C}$ & 2.49940 & -6.75433 & -1.37496 \\
\hline $\mathrm{C}$ & 3.69372 & -7.44137 & -2.06706 \\
\hline $\mathrm{C}$ & 1.19367 & -7.04535 & -2.13430 \\
\hline $\mathrm{C}$ & 2.97354 & -2.09745 & -3.32250 \\
\hline $\mathrm{C}$ & 1.62016 & -2.16246 & -4.05230 \\
\hline $\mathrm{C}$ & 4.12953 & -2.41194 & -4.29323 \\
\hline $\mathrm{C}$ & -3.67988 & 6.02997 & -2.00471 \\
\hline $\mathrm{C}$ & -4.09905 & 5.28161 & -3.28287 \\
\hline $\mathrm{C}$ & -3.46626 & 7.52894 & -2.29158 \\
\hline $\mathrm{C}$ & 1.17832 & 4.67397 & -2.26425 \\
\hline $\mathrm{C}$ & 1.64740 & 6.07964 & -2.68886 \\
\hline $\mathrm{C}$ & 1.02164 & 3.74545 & -3.48314 \\
\hline $\mathrm{C}$ & -1.51900 & 4.03741 & 2.10328 \\
\hline $\mathrm{C}$ & -2.56761 & 2.92212 & 2.25950 \\
\hline $\mathrm{C}$ & -1.83665 & 5.23192 & 3.02276 \\
\hline $\mathrm{H}$ & -3.93540 & -3.20181 & 2.95899 \\
\hline $\mathrm{H}$ & -2.39180 & -3.45253 & 4.19439 \\
\hline $\mathrm{H}$ & -2.15323 & -2.30249 & 5.52362 \\
\hline $\mathrm{H}$ & -0.20576 & -3.78120 & 5.42524 \\
\hline $\mathrm{H}$ & -0.00611 & -3.48674 & 3.68056 \\
\hline
\end{tabular}




\begin{tabular}{|c|c|c|c|}
\hline $\mathrm{H}$ & 1.10807 & -0.11800 & 4.30382 \\
\hline $\mathrm{H}$ & 0.77024 & -1.27845 & 3.00201 \\
\hline $\mathrm{H}$ & -1.02957 & 0.32163 & 3.02738 \\
\hline $\mathrm{H}$ & -1.27624 & 0.12296 & 4.79934 \\
\hline $\mathrm{H}$ & -4.60705 & -2.69101 & 0.34220 \\
\hline $\mathrm{H}$ & -4.88541 & -4.13966 & -0.66792 \\
\hline $\mathrm{H}$ & -0.97511 & -1.43802 & -1.48286 \\
\hline $\mathrm{H}$ & -2.77778 & -1.17938 & -4.15847 \\
\hline $\mathrm{H}$ & -3.53167 & -0.00035 & -3.12169 \\
\hline $\mathrm{H}$ & -1.75865 & -0.24780 & -3.02489 \\
\hline $\mathrm{H}$ & -0.28916 & -3.22262 & 1.13909 \\
\hline $\mathrm{H}$ & 0.09608 & -4.28529 & -0.21993 \\
\hline $\mathrm{H}$ & 0.37234 & -2.55749 & -0.35614 \\
\hline $\mathrm{H}$ & -6.46274 & -4.08280 & -2.25461 \\
\hline $\mathrm{H}$ & -6.91193 & -2.68898 & -1.26688 \\
\hline $\mathrm{H}$ & -7.36768 & -2.73552 & -2.98921 \\
\hline $\mathrm{H}$ & -1.06291 & -6.09716 & 0.32622 \\
\hline $\mathrm{H}$ & -2.03874 & -6.69179 & 1.69534 \\
\hline $\mathrm{H}$ & -1.05600 & -5.21816 & 1.85185 \\
\hline $\mathrm{H}$ & 5.22413 & 1.74701 & 2.22841 \\
\hline $\mathrm{H}$ & 2.88987 & 5.90483 & 3.63232 \\
\hline $\mathrm{H}$ & 4.95101 & 5.18049 & 4.79825 \\
\hline $\mathrm{H}$ & 6.09665 & 3.07848 & 4.09853 \\
\hline $\mathrm{H}$ & 1.22012 & 5.58099 & 1.86737 \\
\hline $\mathrm{H}$ & 5.82336 & -1.69122 & -1.53690 \\
\hline $\mathrm{H}$ & 5.06135 & 3.63619 & -0.18003 \\
\hline $\mathrm{H}$ & 7.27372 & 4.01822 & -1.14716 \\
\hline $\mathrm{H}$ & 8.61336 & 2.11691 & -2.05054 \\
\hline $\mathrm{H}$ & 7.66015 & -0.17081 & -2.03023 \\
\hline $\mathrm{H}$ & -3.42008 & 5.10893 & 0.54596 \\
\hline $\mathrm{H}$ & -1.19276 & 5.58271 & -3.06906 \\
\hline $\mathrm{H}$ & 2.41565 & -4.71851 & -3.22694 \\
\hline $\mathrm{H}$ & 3.20385 & -5.46720 & 0.90610 \\
\hline $\mathrm{H}$ & 3.86315 & -1.88970 & 1.70005 \\
\hline $\mathrm{H}$ & 6.07429 & -2.81480 & 1.05035 \\
\hline $\mathrm{H}$ & 5.83140 & -2.94381 & 2.80063 \\
\hline $\mathrm{H}$ & 5.65032 & -4.37543 & 1.77091 \\
\hline $\mathrm{H}$ & 2.08712 & -3.39162 & 2.66848 \\
\hline $\mathrm{H}$ & 3.31559 & -4.64018 & 2.92869 \\
\hline $\mathrm{H}$ & 3.44474 & -3.08903 & 3.75802 \\
\hline $\mathrm{H}$ & 2.40340 & -7.19578 & -0.37366 \\
\hline $\mathrm{H}$ & 4.61967 & -7.28133 & -1.50652 \\
\hline $\mathrm{H}$ & 3.52782 & -8.52108 & -2.15340 \\
\hline $\mathrm{H}$ & 3.84220 & -7.04145 & -3.07609 \\
\hline $\mathrm{H}$ & 0.33170 & -6.57427 & -1.65020 \\
\hline $\mathrm{H}$ & 1.23420 & -6.67690 & -3.16463 \\
\hline
\end{tabular}




$\begin{array}{lrrr}\mathrm{H} & 1.00762 & -8.12369 & -2.17984 \\ \mathrm{H} & 3.09676 & -1.06647 & -2.98173 \\ \mathrm{H} & 0.81230 & -1.86495 & -3.38212 \\ \mathrm{H} & 1.62346 & -1.47106 & -4.90206 \\ \mathrm{H} & 1.41073 & -3.16297 & -4.44725 \\ \mathrm{H} & 5.10469 & -2.30895 & -3.80783 \\ \mathrm{H} & 4.05644 & -3.43564 & -4.67788 \\ \mathrm{H} & 4.10605 & -1.73039 & -5.15060 \\ \mathrm{H} & -4.50865 & 5.95096 & -1.28774 \\ \mathrm{H} & -4.27742 & 4.22044 & -3.08383 \\ \mathrm{H} & -3.32603 & 5.34739 & -4.05574 \\ \mathrm{H} & -5.01764 & 5.71038 & -3.69841 \\ \mathrm{H} & -2.65134 & 7.67989 & -3.00786 \\ \mathrm{H} & -4.37162 & 7.97756 & -2.71563 \\ \mathrm{H} & -3.21046 & 8.07359 & -1.37758 \\ \mathrm{H} & 1.97140 & 4.25392 & -1.64207 \\ \mathrm{H} & 1.79476 & 6.72879 & -1.81967 \\ \mathrm{H} & 2.59727 & 6.01712 & -3.23129 \\ \mathrm{H} & 0.92104 & 6.56664 & -3.34861 \\ \mathrm{H} & 0.73682 & 2.73847 & -3.16935 \\ \mathrm{H} & 0.26200 & 4.11958 & -4.17882 \\ \mathrm{H} & 1.96731 & 3.67819 & -4.03253 \\ \mathrm{H} & -0.56399 & 3.61860 & 2.42812 \\ \mathrm{H} & -2.29321 & 2.06344 & 1.64146 \\ \mathrm{H} & -2.62436 & 2.59818 & 3.30585 \\ \mathrm{H} & -3.56847 & 3.25472 & 1.96520 \\ \mathrm{H} & -1.07141 & 6.01137 & 2.94822 \\ \mathrm{H} & -2.79891 & 5.69027 & 2.76926 \\ \mathrm{H} & -1.88916 & 4.90880 & 4.06858 \\ \mathrm{C} & -6.12570 & 1.79783 & -0.14931 \\ \mathrm{C} & -7.06388 & 0.99963 & 0.51558 \\ \mathrm{C} & -6.71198 & -0.23500 & 1.05333 \\ \mathrm{C} & -5.39443 & -0.72090 & 0.96781 \\ \mathrm{C} & -4.45312 & 0.08416 & 0.29706 \\ \mathrm{C} & -4.81332 & 1.31709 & -0.24268 \\ \mathrm{H} & -6.51971 & 3.11609 & -0.76737 \\ \mathrm{H} & -8.08847 & 1.34889 & 0.61555 \\ \mathrm{H} & -7.47176 & -0.81286 & 1.56703 \\ \mathrm{H} & -4.42572 & -0.24398 & 0.18593 \\ \mathrm{H} & -6.714987 & 1.91630 & -0.73934 \\ \mathrm{H} & -6.85173 & -0.68124 \\ \mathrm{H} & 2.99966 & -1.83602 \\ \mathrm{H} & -2.52919 & -0.29360 \\ \mathrm{H} & -2.67002 & 2.76979 \\ \mathrm{H} & -3.00459 & 1.04682\end{array}$


$\begin{array}{llll}\mathrm{H} & -5.85393 & -4.01025 & 1.99690\end{array}$

TS6-E

B3LYP/6-31G(d,p) Energy = -3928.589295

B3LYP/6-31G(d,p) Free Energy = -3927.216061

Number of Imaginary Frequencies $=1(-858.27)$

\begin{tabular}{|c|c|c|c|}
\hline \multicolumn{4}{|c|}{ B3LYP/6-31G(d,p) Geometry } \\
\hline $\mathrm{C}$ & -2.52216 & -2.70308 & 1.74811 \\
\hline $\mathrm{C}$ & -3.55659 & -3.27130 & 0.90755 \\
\hline $\mathrm{C}$ & -2.22640 & -3.18786 & 2.99981 \\
\hline $\mathrm{C}$ & -4.14993 & -2.39241 & -0.16004 \\
\hline $\mathrm{C}$ & -4.48641 & -4.31341 & 1.53036 \\
\hline $\mathrm{C}$ & -3.68909 & -1.08325 & -0.40047 \\
\hline $\mathrm{C}$ & -4.22117 & -0.30664 & -1.42772 \\
\hline $\mathrm{C}$ & -5.23255 & -0.79538 & -2.26605 \\
\hline $\mathrm{C}$ & -5.68844 & -2.10004 & -2.03652 \\
\hline $\mathrm{C}$ & -5.15872 & -2.88116 & -1.01315 \\
\hline $\mathrm{C}$ & -5.82056 & 0.05487 & -3.36586 \\
\hline $\mathrm{N}$ & -1.30798 & -2.73366 & 3.88113 \\
\hline $\mathrm{C}$ & -1.09598 & -3.40810 & 5.16206 \\
\hline $\mathrm{C}$ & -1.03050 & -2.37591 & 6.29078 \\
\hline $\mathrm{O}$ & -0.03241 & -1.40454 & 6.02912 \\
\hline $\mathrm{C}$ & -0.30593 & -0.70517 & 4.81733 \\
\hline $\mathrm{C}$ & -0.35117 & -1.65324 & 3.61883 \\
\hline $\mathrm{H}$ & -2.79071 & -4.03025 & 3.38686 \\
\hline $\mathrm{C}$ & -2.02442 & -4.82483 & -0.67964 \\
\hline $\mathrm{C}$ & -0.74838 & -4.68234 & 0.01212 \\
\hline $\mathrm{C}$ & 0.05487 & -3.61505 & -0.35018 \\
\hline $\mathrm{N}$ & -0.32939 & -2.84050 & -1.41077 \\
\hline $\mathrm{C}$ & -1.33684 & -3.14563 & -2.28932 \\
\hline $\mathrm{C}$ & -2.14664 & -4.23118 & -2.00770 \\
\hline $\mathrm{C}$ & -1.41164 & -2.20540 & -3.46384 \\
\hline $\mathrm{C}$ & 1.34297 & -3.17613 & 0.28973 \\
\hline $\mathrm{C}$ & -3.20325 & -4.82206 & -2.87390 \\
\hline $\mathrm{C}$ & -0.51969 & -5.63680 & 1.12848 \\
\hline $\mathrm{C}$ & -3.34240 & -4.45584 & -4.34109 \\
\hline $\mathrm{O}$ & -3.96465 & -5.65894 & -2.39602 \\
\hline $\mathrm{C}$ & 0.86067 & -5.87480 & 1.71834 \\
\hline $\mathrm{O}$ & -1.46983 & -6.28492 & 1.56174 \\
\hline $\mathrm{C}$ & 3.54466 & 4.98750 & -1.39704 \\
\hline $\mathrm{C}$ & 3.71316 & 3.60650 & -1.09707 \\
\hline $\mathrm{C}$ & 4.88007 & 2.95102 & -1.60213 \\
\hline $\mathrm{C}$ & 5.84729 & 3.69700 & -2.32845 \\
\hline $\mathrm{C}$ & 5.66205 & 5.03557 & -2.58210 \\
\hline $\mathrm{C}$ & 4.48998 & 5.67958 & -2.12092 \\
\hline
\end{tabular}




\begin{tabular}{|c|c|c|c|}
\hline $\mathrm{C}$ & 2.75674 & 2.84019 & -0.34314 \\
\hline $\mathrm{C}$ & 2.90926 & 1.46135 & -0.26771 \\
\hline $\mathrm{C}$ & 4.07355 & 0.79477 & -0.75867 \\
\hline $\mathrm{C}$ & 5.03888 & 1.56217 & -1.37914 \\
\hline $\mathrm{C}$ & 1.61197 & 3.51258 & 0.33318 \\
\hline $\mathrm{C}$ & 1.83516 & 4.57560 & 1.27568 \\
\hline $\mathrm{C}$ & 0.71341 & 5.32568 & 1.75051 \\
\hline $\mathrm{C}$ & -0.58335 & 4.98342 & 1.29685 \\
\hline $\mathrm{C}$ & -0.82249 & 3.89195 & 0.48526 \\
\hline $\mathrm{C}$ & 0.30562 & 3.13232 & 0.04941 \\
\hline $\mathrm{C}$ & 3.12147 & 4.90397 & 1.78793 \\
\hline $\mathrm{C}$ & 3.28688 & 5.92976 & 2.69187 \\
\hline $\mathrm{C}$ & 2.17882 & 6.69267 & 3.12980 \\
\hline $\mathrm{C}$ & 0.91918 & 6.39158 & 2.66766 \\
\hline $\mathrm{C}$ & 4.32100 & -0.67730 & -0.60107 \\
\hline $\mathrm{O}$ & 0.08566 & 2.04743 & -0.77805 \\
\hline $\mathrm{O}$ & 1.95090 & 0.71834 & 0.39526 \\
\hline $\mathrm{C}$ & -2.23422 & 3.60006 & 0.06946 \\
\hline $\mathrm{C}$ & 4.65999 & -1.21019 & 0.66499 \\
\hline $\mathrm{C}$ & 5.02745 & -2.55826 & 0.75758 \\
\hline $\mathrm{C}$ & 5.08958 & -3.39653 & -0.35761 \\
\hline $\mathrm{C}$ & 4.73382 & -2.85332 & -1.59486 \\
\hline $\mathrm{C}$ & 4.34640 & -1.51615 & -1.74368 \\
\hline $\mathrm{C}$ & -3.19310 & 3.22403 & 1.04122 \\
\hline $\mathrm{C}$ & -4.53807 & 3.11694 & 0.66656 \\
\hline $\mathrm{C}$ & -4.97190 & 3.36021 & -0.63684 \\
\hline $\mathrm{C}$ & -4.00286 & 3.69456 & -1.58667 \\
\hline $\mathrm{C}$ & -2.64689 & 3.82631 & -1.26636 \\
\hline $\mathrm{P}$ & 0.43443 & 0.50635 & -0.26863 \\
\hline $\mathrm{O}$ & -0.45547 & 0.05341 & 0.84960 \\
\hline $\mathrm{O}$ & 0.55691 & -0.30677 & -1.54053 \\
\hline $\mathrm{C}$ & -1.67951 & 4.25966 & -2.36761 \\
\hline $\mathrm{C}$ & -2.04161 & 5.65048 & -2.92447 \\
\hline $\mathrm{C}$ & -1.58862 & 3.21311 & -3.49380 \\
\hline $\mathrm{C}$ & -6.44594 & 3.33668 & -1.02512 \\
\hline $\mathrm{C}$ & -7.09122 & 4.71575 & -0.77682 \\
\hline $\mathrm{C}$ & -7.25480 & 2.22800 & -0.33279 \\
\hline $\mathrm{C}$ & -2.82736 & 2.91722 & 2.49440 \\
\hline $\mathrm{C}$ & -3.13451 & 1.45124 & 2.85134 \\
\hline $\mathrm{C}$ & -3.51405 & 3.88401 & 3.47804 \\
\hline $\mathrm{C}$ & 5.59701 & -4.82778 & -0.22235 \\
\hline $\mathrm{C}$ & 7.03522 & -4.95235 & -0.76402 \\
\hline $\mathrm{C}$ & 4.67695 & -5.86730 & -0.88484 \\
\hline $\mathrm{C}$ & 3.98881 & -1.01596 & -3.14503 \\
\hline $\mathrm{C}$ & 2.82338 & -1.80892 & -3.76393 \\
\hline $\mathrm{C}$ & 5.21479 & -1.02655 & -4.07905 \\
\hline
\end{tabular}




\begin{tabular}{|c|c|c|c|}
\hline $\mathrm{C}$ & 4.69481 & -0.35498 & 1.93119 \\
\hline $\mathrm{C}$ & 6.11276 & -0.28812 & 2.53098 \\
\hline $\mathrm{C}$ & 3.66918 & -0.83416 & 2.97490 \\
\hline $\mathrm{H}$ & -1.93719 & -1.88006 & 1.35528 \\
\hline $\mathrm{H}$ & -5.09879 & -4.80981 & 0.77882 \\
\hline $\mathrm{H}$ & -5.15912 & -3.83721 & 2.25285 \\
\hline $\mathrm{H}$ & -3.91477 & -5.09683 & 2.03051 \\
\hline $\mathrm{H}$ & -2.90109 & -0.64666 & 0.20136 \\
\hline $\mathrm{H}$ & -3.83972 & 0.69958 & -1.57443 \\
\hline $\mathrm{H}$ & -6.46484 & -2.51840 & -2.67258 \\
\hline $\mathrm{H}$ & -5.51745 & -3.89799 & -0.91210 \\
\hline $\mathrm{H}$ & -6.71626 & 0.58396 & -3.01783 \\
\hline $\mathrm{H}$ & -5.10926 & 0.81144 & -3.70850 \\
\hline $\mathrm{H}$ & -6.11923 & -0.55188 & -4.22650 \\
\hline $\mathrm{H}$ & -0.14789 & -3.96500 & 5.13357 \\
\hline $\mathrm{H}$ & -1.90671 & -4.12061 & 5.33699 \\
\hline $\mathrm{H}$ & -2.01640 & -1.89654 & 6.40789 \\
\hline $\mathrm{H}$ & -0.76356 & -2.86238 & 7.23348 \\
\hline $\mathrm{H}$ & -1.26161 & -0.16582 & 4.90014 \\
\hline $\mathrm{H}$ & 0.49702 & 0.02334 & 4.68466 \\
\hline $\mathrm{H}$ & 0.64679 & -2.09466 & 3.48262 \\
\hline $\mathrm{H}$ & -0.60119 & -1.10400 & 2.70973 \\
\hline $\mathrm{H}$ & -2.84304 & -4.11527 & 0.07785 \\
\hline $\mathrm{H}$ & -2.51926 & -5.78524 & -0.55790 \\
\hline $\mathrm{H}$ & 0.11321 & -1.88849 & -1.49953 \\
\hline $\mathrm{H}$ & -2.44324 & -1.98843 & -3.73670 \\
\hline $\mathrm{H}$ & -0.91446 & -1.26666 & -3.20921 \\
\hline $\mathrm{H}$ & -0.90339 & -2.62647 & -4.33866 \\
\hline $\mathrm{H}$ & 1.26115 & -3.13772 & 1.37551 \\
\hline $\mathrm{H}$ & 2.15955 & -3.85742 & 0.03469 \\
\hline $\mathrm{H}$ & 1.63140 & -2.18839 & -0.06696 \\
\hline $\mathrm{H}$ & -3.94430 & -5.23027 & -4.81857 \\
\hline $\mathrm{H}$ & -3.86928 & -3.50089 & -4.44293 \\
\hline $\mathrm{H}$ & -2.38079 & -4.36504 & -4.85145 \\
\hline $\mathrm{H}$ & 1.13764 & -5.07093 & 2.40789 \\
\hline $\mathrm{H}$ & 1.63769 & -5.93153 & 0.95180 \\
\hline $\mathrm{H}$ & 0.82366 & -6.81015 & 2.27848 \\
\hline $\mathrm{H}$ & 2.65014 & 5.49635 & -1.05981 \\
\hline $\mathrm{H}$ & 6.73227 & 3.18174 & -2.69286 \\
\hline $\mathrm{H}$ & 6.40303 & 5.59556 & -3.14487 \\
\hline $\mathrm{H}$ & 4.33098 & 6.73059 & -2.34401 \\
\hline $\mathrm{H}$ & 5.94635 & 1.08039 & -1.73198 \\
\hline $\mathrm{H}$ & -1.42371 & 5.59249 & 1.61795 \\
\hline $\mathrm{H}$ & 3.97994 & 4.32533 & 1.46892 \\
\hline $\mathrm{H}$ & 4.27824 & 6.15252 & 3.07568 \\
\hline $\mathrm{H}$ & 2.32466 & 7.50400 & 3.83679 \\
\hline
\end{tabular}




\begin{tabular}{|c|c|c|c|}
\hline $\mathrm{H}$ & 0.05517 & 6.95673 & 3.00760 \\
\hline $\mathrm{H}$ & 5.30441 & -2.96241 & 1.72877 \\
\hline $\mathrm{H}$ & 4.77220 & -3.48242 & -2.48000 \\
\hline $\mathrm{H}$ & -5.26446 & 2.83779 & 1.42351 \\
\hline $\mathrm{H}$ & -4.32146 & 3.88566 & -2.60918 \\
\hline $\mathrm{H}$ & -0.68220 & 4.34536 & -1.93095 \\
\hline $\mathrm{H}$ & -2.07282 & 6.40071 & -2.12787 \\
\hline $\mathrm{H}$ & -1.29880 & 5.97061 & -3.66345 \\
\hline $\mathrm{H}$ & -3.01945 & 5.64819 & -3.41830 \\
\hline $\mathrm{H}$ & -0.86502 & 3.53198 & -4.25231 \\
\hline $\mathrm{H}$ & -2.55421 & 3.07795 & -3.99505 \\
\hline $\mathrm{H}$ & -1.26185 & 2.24803 & -3.09879 \\
\hline $\mathrm{H}$ & -6.48652 & 3.14873 & -2.10691 \\
\hline $\mathrm{H}$ & -6.55588 & 5.50622 & -1.31156 \\
\hline $\mathrm{H}$ & -8.13580 & 4.72471 & -1.10832 \\
\hline $\mathrm{H}$ & -7.07281 & 4.96417 & 0.29019 \\
\hline $\mathrm{H}$ & -6.79007 & 1.24678 & -0.46632 \\
\hline $\mathrm{H}$ & -7.34948 & 2.40930 & 0.74330 \\
\hline $\mathrm{H}$ & -8.27041 & 2.18754 & -0.74121 \\
\hline $\mathrm{H}$ & -1.74915 & 3.04876 & 2.60782 \\
\hline $\mathrm{H}$ & -2.54440 & 0.77895 & 2.22385 \\
\hline $\mathrm{H}$ & -2.88148 & 1.25849 & 3.90083 \\
\hline $\mathrm{H}$ & -4.19515 & 1.21124 & 2.71979 \\
\hline $\mathrm{H}$ & -4.60458 & 3.78380 & 3.44932 \\
\hline $\mathrm{H}$ & -3.27326 & 4.92746 & 3.25048 \\
\hline $\mathrm{H}$ & -3.19043 & 3.67934 & 4.50465 \\
\hline $\mathrm{H}$ & 5.63062 & -5.05562 & 0.85155 \\
\hline $\mathrm{H}$ & 7.70715 & -4.24853 & -0.26375 \\
\hline $\mathrm{H}$ & 7.06806 & -4.73778 & -1.83783 \\
\hline $\mathrm{H}$ & 7.42426 & -5.96520 & -0.61089 \\
\hline $\mathrm{H}$ & 4.61690 & -5.72266 & -1.96862 \\
\hline $\mathrm{H}$ & 5.05341 & -6.88085 & -0.71017 \\
\hline $\mathrm{H}$ & 3.65847 & -5.81435 & -0.48611 \\
\hline $\mathrm{H}$ & 3.64994 & 0.01842 & -3.05684 \\
\hline $\mathrm{H}$ & 1.93129 & -1.71242 & -3.14260 \\
\hline $\mathrm{H}$ & 2.58770 & -1.41414 & -4.75865 \\
\hline $\mathrm{H}$ & 3.06419 & -2.87178 & -3.87913 \\
\hline $\mathrm{H}$ & 6.03660 & -0.42823 & -3.67342 \\
\hline $\mathrm{H}$ & 5.59240 & -2.04353 & -4.23375 \\
\hline $\mathrm{H}$ & 4.95187 & -0.61692 & -5.06050 \\
\hline $\mathrm{H}$ & 4.41798 & 0.66568 & 1.65772 \\
\hline $\mathrm{H}$ & 6.83454 & 0.08692 & 1.79855 \\
\hline $\mathrm{H}$ & 6.12948 & 0.38170 & 3.39772 \\
\hline $\mathrm{H}$ & 6.45868 & -1.27193 & 2.86621 \\
\hline $\mathrm{H}$ & 2.65922 & -0.80032 & 2.55781 \\
\hline $\mathrm{H}$ & 3.87901 & -1.85792 & 3.30588 \\
\hline
\end{tabular}


$\begin{array}{llll}\mathrm{H} & 3.69507 & -0.18945 & 3.86047\end{array}$

TS6-Z

B3LYP/6-31G(d,p) Energy = -3928.594002

B3LYP/6-31G(d,p) Free Energy = -3927.222557

Number of Imaginary Frequencies $=1$ (-923.69)

$\begin{array}{lccc}\text { B } 3 L Y P / 6-31 G(d, p) & \text { Geometry } & \\ \mathrm{C} & 3.94408 & 0.07131 & 1.25964 \\ \mathrm{C} & 4.99803 & -0.53344 & 0.49617 \\ \mathrm{C} & 4.00488 & 1.34338 & 1.79667 \\ \mathrm{C} & 6.44671 & -0.21427 & 0.76326 \\ \mathrm{C} & 4.74921 & -1.98434 & 0.09543 \\ \mathrm{C} & 7.40870 & -0.36004 & -0.25463 \\ \mathrm{C} & 8.75751 & -0.13281 & 0.00056 \\ \mathrm{C} & 9.20970 & 0.23421 & 1.27704 \\ \mathrm{C} & 8.25642 & 0.35168 & 2.29350 \\ \mathrm{C} & 6.90121 & 0.13249 & 2.04560 \\ \mathrm{C} & 10.67240 & 0.50120 & 1.53602 \\ \mathrm{~N} & 3.05512 & 1.98579 & 2.49876 \\ \mathrm{C} & 3.39093 & 3.24319 & 3.18262 \\ \mathrm{C} & 2.16147 & 4.14315 & 3.28904 \\ \mathrm{O} & 1.08933 & 3.45849 & 3.91273 \\ \mathrm{C} & 0.69402 & 2.33975 & 3.12445 \\ \mathrm{C} & 1.82126 & 1.32451 & 2.95450 \\ \mathrm{H} & 4.91489 & 1.92187 & 1.66791 \\ \mathrm{C} & 4.53217 & 0.68667 & -1.89566 \\ \mathrm{C} & 3.81601 & 1.87748 & -1.44904 \\ \mathrm{C} & 2.42692 & 1.82796 & -1.42330 \\ \mathrm{~N} & 1.79475 & 0.74031 & -1.94566 \\ \mathrm{C} & 2.40723 & -0.27736 & -2.63038 \\ \mathrm{C} & 3.78800 & -0.29216 & -2.70255 \\ \mathrm{C} & 1.43734 & -1.26487 & -3.22990 \\ \mathrm{C} & 1.51790 & 2.90320 & -0.90779 \\ \mathrm{C} & 4.63689 & -1.25233 & -3.44818 \\ \mathrm{C} & 4.55689 & 3.08292 & -0.99749 \\ \mathrm{C} & 4.08011 & -2.19475 & -4.49945 \\ \mathrm{O} & 5.85007 & -1.26589 & -3.22943 \\ \mathrm{C} & 6.03390 & 3.19381 & -1.34999 \\ \mathrm{O} & 4.01889 & 3.98955 & -0.36418 \\ \mathrm{C} & -6.54970 & -1.51662 & -0.80688 \\ \mathrm{C} & -5.73852 & -0.35536 & -0.67032 \\ \mathrm{C} & -6.20538 & 0.85937 & -1.26783 \\ \mathrm{C} & -7.46825 & 0.88102 & -1.91864 \\ \mathrm{C} & -8.23652 & -0.25572 & -2.01201 \\ \mathrm{C} & -7.76133 & -1.46801 & -1.46017\end{array}$




\begin{tabular}{|c|c|c|c|}
\hline $\mathrm{C}$ & -4.46627 & -0.35642 & 0.00366 \\
\hline $\mathrm{C}$ & -3.67174 & 0.77953 & -0.07743 \\
\hline $\mathrm{C}$ & -4.12516 & 2.00047 & -0.66397 \\
\hline $\mathrm{C}$ & -5.38873 & 2.01665 & -1.21509 \\
\hline $\mathrm{C}$ & -3.98645 & -1.56191 & 0.74031 \\
\hline $\mathrm{C}$ & -4.76445 & -2.16125 & 1.79123 \\
\hline $\mathrm{C}$ & -4.34630 & -3.41838 & 2.33477 \\
\hline $\mathrm{C}$ & -3.17174 & -4.03342 & 1.83254 \\
\hline $\mathrm{C}$ & -2.36243 & -3.41856 & 0.90016 \\
\hline $\mathrm{C}$ & -2.76874 & -2.14202 & 0.40658 \\
\hline $\mathrm{C}$ & -5.92013 & -1.54550 & 2.34714 \\
\hline $\mathrm{C}$ & -6.63258 & -2.15035 & 3.35883 \\
\hline $\mathrm{C}$ & -6.23597 & -3.40889 & 3.86827 \\
\hline $\mathrm{C}$ & -5.11397 & -4.02503 & 3.36505 \\
\hline $\mathrm{C}$ & -3.27991 & 3.24051 & -0.65206 \\
\hline $\mathrm{O}$ & -1.95613 & -1.52277 & -0.52053 \\
\hline $\mathrm{O}$ & -2.42488 & 0.77068 & 0.51653 \\
\hline $\mathrm{C}$ & -1.13686 & -4.11371 & 0.38307 \\
\hline $\mathrm{C}$ & -3.14675 & 3.98587 & 0.54420 \\
\hline $\mathrm{C}$ & -2.36272 & 5.14352 & 0.53972 \\
\hline $\mathrm{C}$ & -1.72437 & 5.60536 & -0.61491 \\
\hline $\mathrm{C}$ & -1.89461 & 4.86972 & -1.78830 \\
\hline $\mathrm{C}$ & -2.65743 & 3.69520 & -1.83805 \\
\hline $\mathrm{C}$ & -0.00197 & -4.28264 & 1.21212 \\
\hline $\mathrm{C}$ & 1.09268 & -5.00594 & 0.72443 \\
\hline $\mathrm{C}$ & 1.10893 & -5.56400 & -0.55620 \\
\hline $\mathrm{C}$ & -0.01651 & -5.37384 & -1.35894 \\
\hline $\mathrm{C}$ & -1.14209 & -4.66780 & -0.91859 \\
\hline $\mathrm{P}$ & -1.17579 & -0.10499 & -0.13539 \\
\hline $\mathrm{O}$ & -0.15202 & -0.26523 & 0.94219 \\
\hline $\mathrm{O}$ & -0.78699 & 0.46131 & -1.48941 \\
\hline $\mathrm{C}$ & -2.34902 & -4.56810 & -1.85135 \\
\hline $\mathrm{C}$ & -2.93669 & -5.95898 & -2.16076 \\
\hline $\mathrm{C}$ & -2.01739 & -3.80227 & -3.14533 \\
\hline $\mathrm{C}$ & 2.29286 & -6.38050 & -1.05945 \\
\hline $\mathrm{C}$ & 2.47730 & -7.67533 & -0.24544 \\
\hline $\mathrm{C}$ & 3.59718 & -5.56385 & -1.09173 \\
\hline $\mathrm{C}$ & 0.07457 & -3.70919 & 2.62713 \\
\hline $\mathrm{C}$ & 1.26143 & -2.74221 & 2.78665 \\
\hline $\mathrm{C}$ & 0.11592 & -4.82440 & 3.68934 \\
\hline $\mathrm{C}$ & -0.90209 & 6.88827 & -0.61243 \\
\hline $\mathrm{C}$ & 0.29252 & 6.81661 & 0.35658 \\
\hline $\mathrm{C}$ & -1.77584 & 8.12202 & -0.31582 \\
\hline $\mathrm{C}$ & -2.83578 & 2.98873 & -3.18324 \\
\hline $\mathrm{C}$ & -1.50605 & 2.70616 & -3.90374 \\
\hline $\mathrm{C}$ & -3.78517 & 3.79148 & -4.09618 \\
\hline
\end{tabular}




\begin{tabular}{|c|c|c|c|}
\hline $\mathrm{C}$ & -3.87723 & 3.59758 & 1.83033 \\
\hline $\mathrm{C}$ & -4.83760 & 4.71159 & 2.29085 \\
\hline $\mathrm{C}$ & -2.90498 & 3.19879 & 2.95473 \\
\hline $\mathrm{H}$ & 3.00881 & -0.47617 & 1.31136 \\
\hline $\mathrm{H}$ & 4.92059 & -2.63006 & 0.96481 \\
\hline $\mathrm{H}$ & 5.42710 & -2.30439 & -0.69720 \\
\hline $\mathrm{H}$ & 3.71756 & -2.13420 & -0.23383 \\
\hline $\mathrm{H}$ & 7.09705 & -0.65460 & -1.25317 \\
\hline $\mathrm{H}$ & 9.47550 & -0.24854 & -0.80761 \\
\hline $\mathrm{H}$ & 8.57637 & 0.60864 & 3.30019 \\
\hline $\mathrm{H}$ & 6.19360 & 0.19623 & 2.86508 \\
\hline $\mathrm{H}$ & 11.30889 & -0.21977 & 1.01348 \\
\hline $\mathrm{H}$ & 10.96042 & 1.49953 & 1.18394 \\
\hline $\mathrm{H}$ & 10.90634 & 0.45007 & 2.60293 \\
\hline $\mathrm{H}$ & 4.18085 & 3.74774 & 2.62063 \\
\hline $\mathrm{H}$ & 3.75705 & 3.01991 & 4.19563 \\
\hline $\mathrm{H}$ & 2.39486 & 5.01300 & 3.90957 \\
\hline $\mathrm{H}$ & 1.86965 & 4.49622 & 2.28790 \\
\hline $\mathrm{H}$ & -0.14293 & 1.86415 & 3.63753 \\
\hline $\mathrm{H}$ & 0.34103 & 2.67482 & 2.13936 \\
\hline $\mathrm{H}$ & 1.48786 & 0.58634 & 2.22369 \\
\hline $\mathrm{H}$ & 2.02559 & 0.82198 & 3.91072 \\
\hline $\mathrm{H}$ & 4.82833 & 0.06621 & -0.78531 \\
\hline $\mathrm{H}$ & 5.55103 & 0.83317 & -2.24693 \\
\hline $\mathrm{H}$ & 0.74522 & 0.66133 & -1.78300 \\
\hline $\mathrm{H}$ & 1.70571 & -2.29351 & -2.98236 \\
\hline $\mathrm{H}$ & 0.43279 & -1.07226 & -2.84993 \\
\hline $\mathrm{H}$ & 1.40828 & -1.17737 & -4.32033 \\
\hline $\mathrm{H}$ & 1.70343 & 3.07042 & 0.15467 \\
\hline $\mathrm{H}$ & 1.73820 & 3.85343 & -1.40045 \\
\hline $\mathrm{H}$ & 0.47280 & 2.63682 & -1.06437 \\
\hline $\mathrm{H}$ & 4.92552 & -2.62098 & -5.04064 \\
\hline $\mathrm{H}$ & 3.51512 & -3.01150 & -4.03883 \\
\hline $\mathrm{H}$ & 3.41155 & -1.68673 & -5.19938 \\
\hline $\mathrm{H}$ & 6.19464 & 3.08753 & -2.42855 \\
\hline $\mathrm{H}$ & 6.62696 & 2.41601 & -0.85754 \\
\hline $\mathrm{H}$ & 6.38697 & 4.17301 & -1.02529 \\
\hline $\mathrm{H}$ & -6.19953 & -2.45656 & -0.39859 \\
\hline $\mathrm{H}$ & -7.80910 & 1.81630 & -2.35522 \\
\hline $\mathrm{H}$ & -9.19715 & -0.22927 & -2.51789 \\
\hline $\mathrm{H}$ & -8.35547 & -2.37220 & -1.55637 \\
\hline $\mathrm{H}$ & -5.76832 & 2.94087 & -1.64165 \\
\hline $\mathrm{H}$ & -2.89607 & -5.01527 & 2.20771 \\
\hline $\mathrm{H}$ & -6.23172 & -0.57744 & 1.97360 \\
\hline $\mathrm{H}$ & -7.50507 & -1.65326 & 3.77282 \\
\hline $\mathrm{H}$ & -6.81058 & -3.87838 & 4.66126 \\
\hline
\end{tabular}




\begin{tabular}{|c|c|c|c|}
\hline $\mathrm{H}$ & -4.78713 & -4.98451 & 3.75769 \\
\hline $\mathrm{H}$ & -2.26420 & 5.70946 & 1.46247 \\
\hline $\mathrm{H}$ & -1.42292 & 5.22964 & -2.69944 \\
\hline $\mathrm{H}$ & 1.95524 & -5.14178 & 1.37179 \\
\hline $\mathrm{H}$ & -0.02549 & -5.80991 & -2.35539 \\
\hline $\mathrm{H}$ & -3.12986 & -4.00263 & -1.33754 \\
\hline $\mathrm{H}$ & -3.20871 & -6.48730 & -1.24144 \\
\hline $\mathrm{H}$ & -3.83725 & -5.86500 & -2.77766 \\
\hline $\mathrm{H}$ & -2.22453 & -6.58694 & -2.70726 \\
\hline $\mathrm{H}$ & -1.67006 & -2.79192 & -2.91534 \\
\hline $\mathrm{H}$ & -1.24349 & -4.31375 & -3.72928 \\
\hline $\mathrm{H}$ & -2.90778 & -3.71951 & -3.77846 \\
\hline $\mathrm{H}$ & 2.06391 & -6.67324 & -2.09291 \\
\hline $\mathrm{H}$ & 1.56521 & -8.27964 & -0.25477 \\
\hline $\mathrm{H}$ & 3.29323 & -8.28083 & -0.65573 \\
\hline $\mathrm{H}$ & 2.71889 & -7.45420 & 0.79989 \\
\hline $\mathrm{H}$ & 3.48400 & -4.66073 & -1.70062 \\
\hline $\mathrm{H}$ & 3.89590 & -5.25032 & -0.08560 \\
\hline $\mathrm{H}$ & 4.41793 & -6.15574 & -1.51162 \\
\hline $\mathrm{H}$ & -0.83051 & -3.12252 & 2.80046 \\
\hline $\mathrm{H}$ & 1.16501 & -1.92424 & 2.06897 \\
\hline $\mathrm{H}$ & 1.26874 & -2.31702 & 3.79718 \\
\hline $\mathrm{H}$ & 2.22290 & -3.24659 & 2.63534 \\
\hline $\mathrm{H}$ & -0.75268 & -5.48625 & 3.61108 \\
\hline $\mathrm{H}$ & 1.01330 & -5.44469 & 3.58525 \\
\hline $\mathrm{H}$ & 0.12362 & -4.39490 & 4.69735 \\
\hline $\mathrm{H}$ & -0.49571 & 7.01075 & -1.62531 \\
\hline $\mathrm{H}$ & 0.95360 & 5.97924 & 0.11172 \\
\hline $\mathrm{H}$ & -0.04293 & 6.68886 & 1.39170 \\
\hline $\mathrm{H}$ & 0.88405 & 7.73781 & 0.31102 \\
\hline $\mathrm{H}$ & -2.20370 & 8.07138 & 0.69132 \\
\hline $\mathrm{H}$ & -1.18444 & 9.04223 & -0.38071 \\
\hline $\mathrm{H}$ & -2.60527 & 8.19814 & -1.02559 \\
\hline $\mathrm{H}$ & -3.30049 & 2.01845 & -2.99209 \\
\hline $\mathrm{H}$ & -0.87123 & 2.06829 & -3.28700 \\
\hline $\mathrm{H}$ & -1.69934 & 2.18385 & -4.84776 \\
\hline $\mathrm{H}$ & -0.96313 & 3.62624 & -4.14758 \\
\hline $\mathrm{H}$ & -4.75778 & 3.95690 & -3.62257 \\
\hline $\mathrm{H}$ & -3.36420 & 4.77445 & -4.33639 \\
\hline $\mathrm{H}$ & -3.95441 & 3.25981 & -5.03933 \\
\hline $\mathrm{H}$ & -4.49322 & 2.72065 & 1.61410 \\
\hline $\mathrm{H}$ & -5.54786 & 4.97533 & 1.50070 \\
\hline $\mathrm{H}$ & -5.40907 & 4.38403 & 3.16639 \\
\hline $\mathrm{H}$ & -4.29825 & 5.62279 & 2.57129 \\
\hline $\mathrm{H}$ & -2.30425 & 2.34005 & 2.64732 \\
\hline $\mathrm{H}$ & -2.22733 & 4.01928 & 3.21641 \\
\hline
\end{tabular}


$\begin{array}{llll}\mathrm{H} & -3.45871 & 2.92378 & 3.85969\end{array}$

TS7-E

B3LYP/6-31G(d,p) Energy = -3928.591226

B3LYP/6-31G(d,p) Free Energy = -3927.218457

Number of Imaginary Frequencies $=1(-985.25)$

\begin{tabular}{|c|c|c|c|}
\hline \multicolumn{4}{|c|}{ B3LYP/6-31G(d,p) Geometry } \\
\hline $\mathrm{C}$ & -4.58007 & 0.24400 & -0.06517 \\
\hline $\mathrm{C}$ & -4.64421 & -0.67835 & 1.03414 \\
\hline $\mathrm{C}$ & -3.41868 & 0.80404 & -0.56335 \\
\hline $\mathrm{C}$ & -6.01646 & -0.89231 & 1.62653 \\
\hline $\mathrm{C}$ & -3.51293 & -0.72944 & 2.05670 \\
\hline $\mathrm{C}$ & -6.95703 & 0.15070 & 1.64706 \\
\hline $\mathrm{C}$ & -8.20586 & -0.01837 & 2.24326 \\
\hline $\mathrm{C}$ & -8.56901 & -1.23315 & 2.83465 \\
\hline $\mathrm{C}$ & -7.62711 & -2.27122 & 2.81811 \\
\hline $\mathrm{C}$ & -6.37489 & -2.10903 & 2.23190 \\
\hline $\mathrm{C}$ & -9.93287 & -1.42921 & 3.45131 \\
\hline $\mathrm{N}$ & -3.31950 & 1.62169 & -1.62943 \\
\hline $\mathrm{C}$ & -4.49955 & 2.12343 & -2.34116 \\
\hline $\mathrm{C}$ & -4.15713 & 2.46841 & -3.79114 \\
\hline $\mathrm{O}$ & -3.02957 & 3.32300 & -3.87803 \\
\hline $\mathrm{C}$ & -1.87976 & 2.67426 & -3.34034 \\
\hline $\mathrm{C}$ & -2.06475 & 2.36324 & -1.85941 \\
\hline $\mathrm{H}$ & -2.46304 & 0.60291 & -0.08085 \\
\hline $\mathrm{C}$ & -3.96688 & -2.94285 & -0.31947 \\
\hline $\mathrm{C}$ & -2.79018 & -3.49142 & 0.36572 \\
\hline $\mathrm{C}$ & -1.54224 & -3.03751 & -0.01943 \\
\hline $\mathrm{N}$ & -1.44885 & -2.24899 & -1.13792 \\
\hline $\mathrm{C}$ & -2.47613 & -1.96865 & -1.98989 \\
\hline $\mathrm{C}$ & -3.76367 & -2.35481 & -1.64000 \\
\hline $\mathrm{C}$ & -2.06203 & -1.28799 & -3.26102 \\
\hline $\mathrm{C}$ & -0.22479 & -3.29583 & 0.65201 \\
\hline $\mathrm{C}$ & -4.92500 & -2.09003 & -2.52902 \\
\hline $\mathrm{C}$ & -3.08805 & -4.43131 & 1.47529 \\
\hline $\mathrm{C}$ & -6.28927 & -2.60324 & -2.09260 \\
\hline $\mathrm{O}$ & -4.81875 & -1.48304 & -3.59247 \\
\hline $\mathrm{C}$ & -2.01633 & -5.23357 & 2.19006 \\
\hline $\mathrm{O}$ & -4.26139 & -4.59399 & 1.81411 \\
\hline $\mathrm{C}$ & 6.23044 & 1.83476 & -0.31999 \\
\hline $\mathrm{C}$ & 5.50518 & 0.61386 & -0.22519 \\
\hline $\mathrm{C}$ & 6.11605 & -0.56897 & -0.74785 \\
\hline $\mathrm{C}$ & 7.42594 & -0.50164 & -1.29427 \\
\hline $\mathrm{C}$ & 8.10530 & 0.69234 & -1.35437 \\
\hline $\mathrm{C}$ & 7.49180 & 1.87209 & -0.87160 \\
\hline
\end{tabular}




\begin{tabular}{|c|c|c|c|}
\hline $\mathrm{C}$ & 4.18558 & 0.52238 & 0.33938 \\
\hline $\mathrm{C}$ & 3.48076 & -0.66810 & 0.22533 \\
\hline $\mathrm{C}$ & 4.09026 & -1.86401 & -0.26549 \\
\hline $\mathrm{C}$ & 5.39401 & -1.78616 & -0.71207 \\
\hline $\mathrm{C}$ & 3.57486 & 1.69406 & 1.02487 \\
\hline $\mathrm{C}$ & 4.22939 & 2.31177 & 2.14564 \\
\hline $\mathrm{C}$ & 3.71501 & 3.54597 & 2.65274 \\
\hline $\mathrm{C}$ & 2.58124 & 4.12112 & 2.02996 \\
\hline $\mathrm{C}$ & 1.88758 & 3.48770 & 1.01774 \\
\hline $\mathrm{C}$ & 2.37111 & 2.21947 & 0.57202 \\
\hline $\mathrm{C}$ & 5.35328 & 1.73702 & 2.80219 \\
\hline $\mathrm{C}$ & 5.94153 & 2.35970 & 3.88056 \\
\hline $\mathrm{C}$ & 5.44728 & 3.59595 & 4.35927 \\
\hline $\mathrm{C}$ & 4.35483 & 4.17317 & 3.75553 \\
\hline $\mathrm{C}$ & 3.41906 & -3.20697 & -0.25672 \\
\hline $\mathrm{O}$ & 1.67716 & 1.55038 & -0.42224 \\
\hline $\mathrm{O}$ & 2.18407 & -0.72182 & 0.70230 \\
\hline $\mathrm{C}$ & 0.73847 & 4.21476 & 0.38253 \\
\hline $\mathrm{C}$ & 3.33085 & -3.93797 & 0.95076 \\
\hline $\mathrm{C}$ & 2.81978 & -5.24175 & 0.91677 \\
\hline $\mathrm{C}$ & 2.40871 & -5.85324 & -0.26953 \\
\hline $\mathrm{C}$ & 2.50231 & -5.10944 & -1.44922 \\
\hline $\mathrm{C}$ & 2.99492 & -3.79951 & -1.47186 \\
\hline $\mathrm{C}$ & -0.45492 & 4.44463 & 1.10946 \\
\hline $\mathrm{C}$ & -1.43543 & 5.27877 & 0.55674 \\
\hline $\mathrm{C}$ & -1.27544 & 5.90216 & -0.68497 \\
\hline $\mathrm{C}$ & -0.10165 & 5.63689 & -1.39350 \\
\hline $\mathrm{C}$ & 0.91205 & 4.81272 & -0.88883 \\
\hline $\mathrm{P}$ & 0.94881 & 0.08676 & -0.08350 \\
\hline $\mathrm{O}$ & -0.18020 & 0.22957 & 0.89081 \\
\hline $\mathrm{O}$ & 0.70204 & -0.56800 & -1.42758 \\
\hline $\mathrm{C}$ & 2.19530 & 4.65187 & -1.70497 \\
\hline $\mathrm{C}$ & 2.90023 & 6.00485 & -1.92368 \\
\hline $\mathrm{C}$ & 1.94450 & 3.93153 & -3.04239 \\
\hline $\mathrm{C}$ & -2.31534 & 6.86984 & -1.23889 \\
\hline $\mathrm{C}$ & -2.51571 & 8.08014 & -0.30745 \\
\hline $\mathrm{C}$ & -3.65743 & 6.18089 & -1.54767 \\
\hline $\mathrm{C}$ & -0.70694 & 3.83244 & 2.48835 \\
\hline $\mathrm{C}$ & -1.89267 & 2.85064 & 2.46885 \\
\hline $\mathrm{C}$ & -0.89500 & 4.91452 & 3.56881 \\
\hline $\mathrm{C}$ & 1.92868 & -7.30003 & -0.27117 \\
\hline $\mathrm{C}$ & 2.98262 & -8.23302 & -0.89941 \\
\hline $\mathrm{C}$ & 0.56394 & -7.48040 & -0.95887 \\
\hline $\mathrm{C}$ & 3.09822 & -3.07384 & -2.81473 \\
\hline $\mathrm{C}$ & 1.77037 & -3.07023 & -3.59177 \\
\hline $\mathrm{C}$ & 4.22805 & -3.66587 & -3.68085 \\
\hline
\end{tabular}




\begin{tabular}{|c|c|c|c|}
\hline $\mathrm{C}$ & 3.81795 & -3.37298 & 2.28530 \\
\hline $\mathrm{C}$ & 4.95305 & -4.22793 & 2.88135 \\
\hline $\mathrm{C}$ & 2.66732 & -3.19362 & 3.29292 \\
\hline $\mathrm{H}$ & -5.51718 & 0.44519 & -0.57107 \\
\hline $\mathrm{H}$ & -3.57339 & -1.64612 & 2.64890 \\
\hline $\mathrm{H}$ & -3.63029 & 0.11199 & 2.74854 \\
\hline $\mathrm{H}$ & -2.51581 & -0.65998 & 1.61609 \\
\hline $\mathrm{H}$ & -6.69776 & 1.11601 & 1.22424 \\
\hline $\mathrm{H}$ & -8.90573 & 0.81355 & 2.25470 \\
\hline $\mathrm{H}$ & -7.87733 & -3.22748 & 3.27098 \\
\hline $\mathrm{H}$ & -5.68074 & -2.94391 & 2.22673 \\
\hline $\mathrm{H}$ & -10.39784 & -0.47316 & 3.70796 \\
\hline $\mathrm{H}$ & -9.87701 & -2.03494 & 4.36115 \\
\hline $\mathrm{H}$ & -10.60924 & -1.94744 & 2.76010 \\
\hline $\mathrm{H}$ & -4.88821 & 3.01206 & -1.82389 \\
\hline $\mathrm{H}$ & -5.27355 & 1.35431 & -2.34320 \\
\hline $\mathrm{H}$ & -4.99761 & 2.99754 & -4.24820 \\
\hline $\mathrm{H}$ & -3.98122 & 1.54145 & -4.35867 \\
\hline $\mathrm{H}$ & -1.67141 & 1.75491 & -3.90777 \\
\hline $\mathrm{H}$ & -1.03960 & 3.35924 & -3.46346 \\
\hline $\mathrm{H}$ & -2.08910 & 3.30079 & -1.29289 \\
\hline $\mathrm{H}$ & -1.23064 & 1.76269 & -1.49166 \\
\hline $\mathrm{H}$ & -4.38668 & -1.91198 & 0.40606 \\
\hline $\mathrm{H}$ & -4.85804 & -3.55112 & -0.18021 \\
\hline $\mathrm{H}$ & -0.54992 & -1.73202 & -1.29917 \\
\hline $\mathrm{H}$ & -2.71815 & -0.44738 & -3.47576 \\
\hline $\mathrm{H}$ & -1.02399 & -0.95798 & -3.19092 \\
\hline $\mathrm{H}$ & -2.17087 & -1.97771 & -4.10446 \\
\hline $\mathrm{H}$ & 0.02696 & -4.35694 & 0.65883 \\
\hline $\mathrm{H}$ & 0.57916 & -2.77965 & 0.13205 \\
\hline $\mathrm{H}$ & -0.23647 & -2.93748 & 1.68348 \\
\hline $\mathrm{H}$ & -7.01995 & -2.31235 & -2.84766 \\
\hline $\mathrm{H}$ & -6.28497 & -3.69539 & -1.99887 \\
\hline $\mathrm{H}$ & -6.58777 & -2.19893 & -1.11983 \\
\hline $\mathrm{H}$ & -2.52235 & -5.92820 & 2.86122 \\
\hline $\mathrm{H}$ & -1.35561 & -4.58960 & 2.77741 \\
\hline $\mathrm{H}$ & -1.38967 & -5.79397 & 1.49020 \\
\hline $\mathrm{H}$ & 5.77469 & 2.74982 & 0.03784 \\
\hline $\mathrm{H}$ & 7.87584 & -1.41441 & -1.67628 \\
\hline $\mathrm{H}$ & 9.10329 & 0.73539 & -1.78039 \\
\hline $\mathrm{H}$ & 8.01941 & 2.81898 & -0.94047 \\
\hline $\mathrm{H}$ & 5.88431 & -2.69082 & -1.06020 \\
\hline $\mathrm{H}$ & 2.24130 & 5.09644 & 2.36731 \\
\hline $\mathrm{H}$ & 5.73933 & 0.78674 & 2.45337 \\
\hline $\mathrm{H}$ & 6.79135 & 1.89442 & 4.37150 \\
\hline $\mathrm{H}$ & 5.92505 & 4.07906 & 5.20644 \\
\hline
\end{tabular}




\begin{tabular}{|c|c|c|c|}
\hline $\mathrm{H}$ & 3.95459 & 5.11575 & 4.11993 \\
\hline $\mathrm{H}$ & 2.76169 & -5.80908 & 1.84310 \\
\hline $\mathrm{H}$ & 2.19683 & -5.56521 & -2.38690 \\
\hline $\mathrm{H}$ & -2.34167 & 5.46328 & 1.12795 \\
\hline $\mathrm{H}$ & 0.04243 & 6.11735 & -2.35847 \\
\hline $\mathrm{H}$ & 2.88446 & 4.02665 & -1.13347 \\
\hline $\mathrm{H}$ & 3.11090 & 6.49987 & -0.97042 \\
\hline $\mathrm{H}$ & 3.85102 & 5.85852 & -2.44784 \\
\hline $\mathrm{H}$ & 2.29195 & 6.68759 & -2.52671 \\
\hline $\mathrm{H}$ & 1.51913 & 2.93857 & -2.87323 \\
\hline $\mathrm{H}$ & 1.26446 & 4.50177 & -3.68617 \\
\hline $\mathrm{H}$ & 2.88498 & 3.80471 & -3.58977 \\
\hline $\mathrm{H}$ & -1.92015 & 7.25076 & -2.18976 \\
\hline $\mathrm{H}$ & -1.56791 & 8.59102 & -0.11183 \\
\hline $\mathrm{H}$ & -3.20688 & 8.80218 & -0.75597 \\
\hline $\mathrm{H}$ & -2.93493 & 7.77540 & 0.65763 \\
\hline $\mathrm{H}$ & -3.52868 & 5.38023 & -2.28199 \\
\hline $\mathrm{H}$ & -4.09889 & 5.75138 & -0.64053 \\
\hline $\mathrm{H}$ & -4.37518 & 6.90264 & -1.95371 \\
\hline $\mathrm{H}$ & 0.17429 & 3.24818 & 2.76196 \\
\hline $\mathrm{H}$ & -1.66793 & 2.00746 & 1.81194 \\
\hline $\mathrm{H}$ & -2.06963 & 2.45432 & 3.47550 \\
\hline $\mathrm{H}$ & -2.81779 & 3.33492 & 2.13505 \\
\hline $\mathrm{H}$ & -0.04008 & 5.59750 & 3.60698 \\
\hline $\mathrm{H}$ & -1.79140 & 5.51804 & 3.38812 \\
\hline $\mathrm{H}$ & -1.00230 & 4.45188 & 4.55595 \\
\hline $\mathrm{H}$ & 1.81037 & -7.59968 & 0.77884 \\
\hline $\mathrm{H}$ & 3.94423 & -8.14448 & -0.38497 \\
\hline $\mathrm{H}$ & 3.14545 & -7.98620 & -1.95425 \\
\hline $\mathrm{H}$ & 2.66026 & -9.27883 & -0.84501 \\
\hline $\mathrm{H}$ & 0.61383 & -7.23195 & -2.02426 \\
\hline $\mathrm{H}$ & 0.22664 & -8.51940 & -0.87936 \\
\hline $\mathrm{H}$ & -0.20220 & -6.84156 & -0.50702 \\
\hline $\mathrm{H}$ & 3.34462 & -2.02890 & -2.61149 \\
\hline $\mathrm{H}$ & 0.98595 & -2.59376 & -3.00206 \\
\hline $\mathrm{H}$ & 1.88370 & -2.50146 & -4.52111 \\
\hline $\mathrm{H}$ & 1.44610 & -4.08085 & -3.86397 \\
\hline $\mathrm{H}$ & 5.19449 & -3.62275 & -3.16995 \\
\hline $\mathrm{H}$ & 4.02996 & -4.71534 & -3.92685 \\
\hline $\mathrm{H}$ & 4.31969 & -3.11319 & -4.62234 \\
\hline $\mathrm{H}$ & 4.23429 & -2.38028 & 2.09759 \\
\hline $\mathrm{H}$ & 5.78563 & -4.32721 & 2.17773 \\
\hline $\mathrm{H}$ & 5.33640 & -3.76675 & 3.79809 \\
\hline $\mathrm{H}$ & 4.61089 & -5.23660 & 3.13727 \\
\hline $\mathrm{H}$ & 1.91539 & -2.50360 & 2.90131 \\
\hline $\mathrm{H}$ & 2.18063 & -4.14867 & 3.52262 \\
\hline
\end{tabular}


$\mathrm{H} \quad 3.04554 \quad-2.78049 \quad 4.23448$

TS7-Z

B3LYP/6-31G(d,p) Energy = -3928.587593

B3LYP/6-31G(d,p) Free Energy = -3927.215769

Number of Imaginary Frequencies $=1$ (-852.40)

$\begin{array}{lccc}\text { B3LYP/6-31G(d,p) Geometry } & \\ \mathrm{C} & -6.01391 & -1.30775 & 0.72360 \\ \mathrm{C} & -5.39575 & -2.45150 & 1.34635 \\ \mathrm{C} & -5.69459 & 0.01090 & 0.95817 \\ \mathrm{~N} & -6.20243 & 1.09607 & 0.34285 \\ \mathrm{C} & -7.12603 & 1.04303 & -0.79413 \\ \mathrm{C} & -6.73055 & 2.10220 & -1.82716 \\ \mathrm{O} & -6.64189 & 3.39446 & -1.24226 \\ \mathrm{C} & -5.65638 & 3.42238 & -0.22075 \\ \mathrm{C} & -6.00382 & 2.43854 & 0.89637 \\ \mathrm{H} & -4.97901 & 0.24732 & 1.74002 \\ \mathrm{C} & -3.98992 & -3.41153 & -0.79768 \\ \mathrm{C} & -2.70916 & -3.91181 & -0.28373 \\ \mathrm{C} & -1.58113 & -3.12570 & -0.43616 \\ \mathrm{~N} & -1.67872 & -1.95812 & -1.14915 \\ \mathrm{C} & -2.79198 & -1.52436 & -1.80473 \\ \mathrm{C} & -3.96052 & -2.27104 & -1.71579 \\ \mathrm{C} & -2.59948 & -0.27101 & -2.61125 \\ \mathrm{C} & -0.20375 & -3.38687 & 0.10734 \\ \mathrm{C} & -5.15955 & -1.92127 & -2.50848 \\ \mathrm{C} & -2.81385 & -5.21023 & 0.43580 \\ \mathrm{C} & -6.22573 & -2.99375 & -2.70621 \\ \mathrm{O} & -5.31583 & -0.81850 & -3.03443 \\ \mathrm{C} & -1.62101 & -5.93158 & 1.03234 \\ \mathrm{O} & -3.92737 & -5.72351 & 0.55046 \\ \mathrm{C} & 5.31509 & 2.47807 & 2.42104 \\ \mathrm{C} & 4.11125 & 2.89814 & 1.79045 \\ \mathrm{C} & 3.48981 & 4.09949 & 2.25927 \\ \mathrm{C} & 4.10940 & 4.84824 & 3.29573 \\ \mathrm{C} & 5.28160 & 4.42031 & 3.87434 \\ \mathrm{C} & 5.88120 & 3.21605 & 3.43686 \\ \mathrm{C} & 3.47933 & 2.15451 & 0.73476 \\ \mathrm{C} & 2.20927 & 2.53564 & 0.32359 \\ \mathrm{C} & 1.60362 & 3.76004 & 0.73346 \\ \mathrm{C} & 2.26971 & 4.52034 & 1.67275 \\ \mathrm{C} & 4.16740 & 1.02001 & 0.05580 \\ & 5.44756 & 1.21651 & -0.57281 \\ \mathrm{C} & 6.13100 & 0.08613 & -1.12322 \\ \mathrm{C} & 5.50783 & -1.18399 & -1.07572\end{array}$




\begin{tabular}{|c|c|c|c|}
\hline $\mathrm{C}$ & 4.23563 & -1.36528 & -0.57340 \\
\hline $\mathrm{C}$ & 3.56350 & -0.23006 & -0.02484 \\
\hline $\mathrm{C}$ & 6.06401 & 2.49261 & -0.70837 \\
\hline $\mathrm{C}$ & 7.29307 & 2.63082 & -1.31428 \\
\hline $\mathrm{C}$ & 7.98264 & 1.50315 & -1.81775 \\
\hline $\mathrm{C}$ & 7.40637 & 0.25824 & -1.72570 \\
\hline $\mathrm{C}$ & 0.33272 & 4.27593 & 0.12477 \\
\hline $\mathrm{O}$ & 2.31990 & -0.42402 & 0.53514 \\
\hline $\mathrm{O}$ & 1.53590 & 1.74736 & -0.58991 \\
\hline $\mathrm{C}$ & 3.64190 & -2.74351 & -0.60693 \\
\hline $\mathrm{C}$ & 0.34607 & 4.79165 & -1.19484 \\
\hline $\mathrm{C}$ & -0.80882 & 5.39651 & -1.69826 \\
\hline $\mathrm{C}$ & -1.97744 & 5.52132 & -0.94240 \\
\hline $\mathrm{C}$ & -1.97476 & 4.98110 & 0.34395 \\
\hline $\mathrm{C}$ & -0.84989 & 4.35115 & 0.89415 \\
\hline $\mathrm{C}$ & 3.58234 & -3.52256 & 0.57321 \\
\hline $\mathrm{C}$ & 3.16223 & -4.85388 & 0.48435 \\
\hline $\mathrm{C}$ & 2.80963 & -5.45043 & -0.73032 \\
\hline $\mathrm{C}$ & 2.85181 & -4.65502 & -1.87674 \\
\hline $\mathrm{C}$ & 3.25354 & -3.31272 & -1.84312 \\
\hline $\mathrm{P}$ & 0.93236 & 0.29345 & -0.05790 \\
\hline $\mathrm{O}$ & 0.49990 & -0.42716 & -1.32130 \\
\hline $\mathrm{O}$ & -0.00358 & 0.43290 & 1.09791 \\
\hline $\mathrm{C}$ & 3.26371 & -2.52423 & -3.15416 \\
\hline $\mathrm{C}$ & 1.86326 & -2.44696 & -3.79085 \\
\hline $\mathrm{C}$ & 4.29462 & -3.09228 & -4.14874 \\
\hline $\mathrm{C}$ & 2.46421 & -6.93575 & -0.77183 \\
\hline $\mathrm{C}$ & 3.73976 & -7.78078 & -0.97008 \\
\hline $\mathrm{C}$ & 1.40751 & -7.30703 & -1.82404 \\
\hline $\mathrm{C}$ & 3.99791 & -2.97060 & 1.93638 \\
\hline $\mathrm{C}$ & 5.18123 & -3.75679 & 2.53282 \\
\hline $\mathrm{C}$ & 2.81165 & -2.91708 & 2.91760 \\
\hline $\mathrm{C}$ & -3.19795 & 6.25501 & -1.48459 \\
\hline $\mathrm{C}$ & -3.72420 & 5.64550 & -2.79652 \\
\hline $\mathrm{C}$ & -2.91620 & 7.76057 & -1.65507 \\
\hline $\mathrm{C}$ & -0.94604 & 3.77116 & 2.30526 \\
\hline $\mathrm{C}$ & -2.07556 & 2.73130 & 2.41932 \\
\hline $\mathrm{C}$ & -1.10255 & 4.87581 & 3.36754 \\
\hline $\mathrm{C}$ & 1.58584 & 4.73973 & -2.08747 \\
\hline $\mathrm{C}$ & 2.06658 & 6.14974 & -2.48134 \\
\hline $\mathrm{C}$ & 1.35017 & 3.86048 & -3.33026 \\
\hline $\mathrm{H}$ & -6.83235 & -1.52930 & 0.04597 \\
\hline $\mathrm{H}$ & -8.15094 & 1.22417 & -0.44077 \\
\hline $\mathrm{H}$ & -7.07570 & 0.06223 & -1.26469 \\
\hline $\mathrm{H}$ & -5.77596 & 1.81273 & -2.28914 \\
\hline $\mathrm{H}$ & -7.49181 & 2.15950 & -2.60919 \\
\hline
\end{tabular}




\begin{tabular}{|c|c|c|c|}
\hline $\mathrm{H}$ & -4.66287 & 3.18482 & -0.63016 \\
\hline $\mathrm{H}$ & -5.63493 & 4.44214 & 0.17197 \\
\hline $\mathrm{H}$ & -6.92837 & 2.76518 & 1.39369 \\
\hline $\mathrm{H}$ & -5.20411 & 2.40373 & 1.64033 \\
\hline $\mathrm{H}$ & -4.63286 & -2.99649 & 0.23953 \\
\hline $\mathrm{H}$ & -4.68426 & -4.21636 & -1.03681 \\
\hline $\mathrm{H}$ & -0.81080 & -1.34923 & -1.20847 \\
\hline $\mathrm{H}$ & -1.54882 & 0.02279 & -2.61272 \\
\hline $\mathrm{H}$ & -2.96050 & -0.41062 & -3.63238 \\
\hline $\mathrm{H}$ & -3.20002 & 0.54028 & -2.19170 \\
\hline $\mathrm{H}$ & -0.21136 & -3.34829 & 1.20023 \\
\hline $\mathrm{H}$ & 0.17927 & -4.36123 & -0.19401 \\
\hline $\mathrm{H}$ & 0.49691 & -2.63449 & -0.25057 \\
\hline $\mathrm{H}$ & -5.79204 & -3.91544 & -3.10920 \\
\hline $\mathrm{H}$ & -6.72003 & -3.25892 & -1.76589 \\
\hline $\mathrm{H}$ & -6.97093 & -2.60818 & -3.40280 \\
\hline $\mathrm{H}$ & -0.87091 & -6.17384 & 0.27391 \\
\hline $\mathrm{H}$ & -1.98917 & -6.85477 & 1.48094 \\
\hline $\mathrm{H}$ & -1.12846 & -5.32832 & 1.79983 \\
\hline $\mathrm{H}$ & 5.78144 & 1.55373 & 2.10126 \\
\hline $\mathrm{H}$ & 3.62918 & 5.76377 & 3.63159 \\
\hline $\mathrm{H}$ & 5.74220 & 4.99678 & 4.67124 \\
\hline $\mathrm{H}$ & 6.79502 & 2.86766 & 3.90946 \\
\hline $\mathrm{H}$ & 1.84231 & 5.46964 & 1.98355 \\
\hline $\mathrm{H}$ & 6.04356 & -2.04164 & -1.47335 \\
\hline $\mathrm{H}$ & 5.54980 & 3.37064 & -0.33826 \\
\hline $\mathrm{H}$ & 7.73469 & 3.61845 & -1.41107 \\
\hline $\mathrm{H}$ & 8.95460 & 1.62561 & -2.28645 \\
\hline $\mathrm{H}$ & 7.91166 & -0.61680 & -2.12642 \\
\hline $\mathrm{H}$ & -0.78568 & 5.80100 & -2.70659 \\
\hline $\mathrm{H}$ & -2.87610 & 5.06683 & 0.94721 \\
\hline $\mathrm{H}$ & 3.12939 & -5.45713 & 1.38932 \\
\hline $\mathrm{H}$ & 2.57249 & -5.08535 & -2.83359 \\
\hline $\mathrm{H}$ & 3.56139 & -1.49821 & -2.92638 \\
\hline $\mathrm{H}$ & 1.16748 & -1.94211 & -3.11686 \\
\hline $\mathrm{H}$ & 1.90718 & -1.87385 & -4.72395 \\
\hline $\mathrm{H}$ & 1.46993 & -3.44092 & -4.03362 \\
\hline $\mathrm{H}$ & 5.30169 & -3.10701 & -3.71966 \\
\hline $\mathrm{H}$ & 4.04615 & -4.11776 & -4.44456 \\
\hline $\mathrm{H}$ & 4.32401 & -2.48281 & -5.05856 \\
\hline $\mathrm{H}$ & 2.05331 & -7.19478 & 0.21414 \\
\hline $\mathrm{H}$ & 4.47962 & -7.56837 & -0.19265 \\
\hline $\mathrm{H}$ & 3.50935 & -8.85178 & -0.94045 \\
\hline $\mathrm{H}$ & 4.20174 & -7.55979 & -1.93866 \\
\hline $\mathrm{H}$ & 0.50284 & -6.69750 & -1.72761 \\
\hline $\mathrm{H}$ & 1.78665 & -7.17509 & -2.84295 \\
\hline
\end{tabular}




\begin{tabular}{|c|c|c|c|}
\hline $\mathrm{H}$ & 1.12022 & -8.35849 & -1.72021 \\
\hline $\mathrm{H}$ & 4.33951 & -1.94272 & 1.79303 \\
\hline $\mathrm{H}$ & 6.03580 & -3.76507 & 1.84885 \\
\hline $\mathrm{H}$ & 5.50550 & -3.30221 & 3.47542 \\
\hline $\mathrm{H}$ & 4.91268 & -4.79786 & 2.74320 \\
\hline $\mathrm{H}$ & 2.01355 & -2.28491 & 2.51936 \\
\hline $\mathrm{H}$ & 2.40547 & -3.91676 & 3.11145 \\
\hline $\mathrm{H}$ & 3.13077 & -2.49732 & 3.87827 \\
\hline $\mathrm{H}$ & -3.99301 & 6.15729 & -0.73280 \\
\hline $\mathrm{H}$ & -3.97290 & 4.58691 & -2.67580 \\
\hline $\mathrm{H}$ & -2.98163 & 5.72328 & -3.59774 \\
\hline $\mathrm{H}$ & -4.62772 & 6.16737 & -3.12971 \\
\hline $\mathrm{H}$ & -2.13411 & 7.93222 & -2.40252 \\
\hline $\mathrm{H}$ & -3.81664 & 8.29044 & -1.98554 \\
\hline $\mathrm{H}$ & -2.58071 & 8.20878 & -0.71479 \\
\hline $\mathrm{H}$ & -0.01594 & 3.23665 & 2.51105 \\
\hline $\mathrm{H}$ & -1.91417 & 1.92136 & 1.70455 \\
\hline $\mathrm{H}$ & -2.08889 & 2.29732 & 3.42553 \\
\hline $\mathrm{H}$ & -3.05831 & 3.18722 & 2.24468 \\
\hline $\mathrm{H}$ & -0.27233 & 5.58814 & 3.33227 \\
\hline $\mathrm{H}$ & -2.02928 & 5.44299 & 3.22232 \\
\hline $\mathrm{H}$ & -1.13171 & 4.44188 & 4.37336 \\
\hline $\mathrm{H}$ & 2.39643 & 4.27866 & -1.51861 \\
\hline $\mathrm{H}$ & 2.26581 & 6.76291 & -1.59655 \\
\hline $\mathrm{H}$ & 2.99069 & 6.08762 & -3.06658 \\
\hline $\mathrm{H}$ & 1.32470 & 6.67646 & -3.09145 \\
\hline $\mathrm{H}$ & 1.06706 & 2.84632 & -3.03786 \\
\hline $\mathrm{H}$ & 0.55823 & 4.27079 & -3.96727 \\
\hline $\mathrm{H}$ & 2.26310 & 3.80046 & -3.93331 \\
\hline $\mathrm{C}$ & -2.11705 & -1.97967 & 4.14867 \\
\hline $\mathrm{C}$ & -2.10465 & -1.31933 & 2.91094 \\
\hline $\mathrm{C}$ & -3.16388 & -1.46924 & 2.01952 \\
\hline $\mathrm{C}$ & -4.27785 & -2.28100 & 2.31808 \\
\hline $\mathrm{C}$ & -4.26509 & -2.96444 & 3.54766 \\
\hline $\mathrm{C}$ & -3.21187 & -2.80399 & 4.44454 \\
\hline $\mathrm{C}$ & -0.98669 & -1.79708 & 5.13117 \\
\hline $\mathrm{H}$ & -1.26255 & -0.69652 & 2.61550 \\
\hline $\mathrm{H}$ & -3.09992 & -0.96683 & 1.06070 \\
\hline $\mathrm{H}$ & -5.08845 & -3.61663 & 3.81693 \\
\hline $\mathrm{H}$ & -3.23931 & -3.33541 & 5.39261 \\
\hline $\mathrm{H}$ & -1.11325 & -0.86991 & 5.70378 \\
\hline $\mathrm{H}$ & -0.93863 & -2.62157 & 5.84839 \\
\hline $\mathrm{H}$ & -0.02285 & -1.72577 & 4.61899 \\
\hline $\mathrm{C}$ & -6.33047 & -3.63759 & 1.55981 \\
\hline $\mathrm{H}$ & -5.78008 & -4.56942 & 1.69208 \\
\hline $\mathrm{H}$ & -6.96210 & -3.46018 & 2.43893 \\
\hline
\end{tabular}


$\begin{array}{llll}\mathrm{H} & -7.00183 & -3.75530 & 0.70461\end{array}$

TS8-E

B3LYP/6-31G(d,p) Energy = -3928.588724

B3LYP/6-31G(d,p) Free Energy = -3927.215606

Number of Imaginary Frequencies $=1(-893.90)$

\begin{tabular}{|c|c|c|c|}
\hline \multicolumn{4}{|c|}{ B3LYP/6-31G(d,p) Geometry } \\
\hline $\mathrm{C}$ & -4.04211 & -2.14699 & 0.58204 \\
\hline $\mathrm{C}$ & -3.84334 & -3.35683 & 1.34567 \\
\hline $\mathrm{C}$ & -4.91709 & -2.01974 & -0.47075 \\
\hline $\mathrm{C}$ & -2.95326 & -3.24635 & 2.54354 \\
\hline $\mathrm{C}$ & -4.98644 & -4.36240 & 1.43875 \\
\hline $\mathrm{C}$ & -1.87127 & -2.34319 & 2.56587 \\
\hline $\mathrm{C}$ & -1.04928 & -2.23090 & 3.68472 \\
\hline $\mathrm{C}$ & -1.25662 & -3.01877 & 4.82413 \\
\hline $\mathrm{C}$ & -2.31707 & -3.93584 & 4.79506 \\
\hline $\mathrm{C}$ & -3.14307 & -4.05306 & 3.68187 \\
\hline $\mathrm{C}$ & -0.39029 & -2.86722 & 6.05006 \\
\hline $\mathrm{N}$ & -5.09074 & -0.94524 & -1.27110 \\
\hline $\mathrm{C}$ & -6.24525 & -0.87808 & -2.17214 \\
\hline $\mathrm{C}$ & -5.86534 & -0.16995 & -3.47066 \\
\hline $\mathrm{O}$ & -5.31712 & 1.11099 & -3.20054 \\
\hline $\mathrm{C}$ & -4.12292 & 0.99885 & -2.43284 \\
\hline $\mathrm{C}$ & -4.37512 & 0.32278 & -1.08384 \\
\hline $\mathrm{H}$ & -5.57119 & -2.84610 & -0.73197 \\
\hline $\mathrm{C}$ & -2.23612 & -4.72735 & -0.37506 \\
\hline $\mathrm{C}$ & -0.91120 & -4.63319 & 0.24406 \\
\hline $\mathrm{C}$ & -0.11042 & -3.56467 & -0.10956 \\
\hline $\mathrm{N}$ & -0.53254 & -2.73872 & -1.12505 \\
\hline $\mathrm{C}$ & -1.60960 & -2.96046 & -1.92671 \\
\hline $\mathrm{C}$ & -2.45965 & -4.02117 & -1.63127 \\
\hline $\mathrm{C}$ & -1.71722 & -2.03963 & -3.10665 \\
\hline $\mathrm{C}$ & 1.20928 & -3.16448 & 0.48687 \\
\hline $\mathrm{C}$ & -3.57359 & -4.40354 & -2.53316 \\
\hline $\mathrm{C}$ & -0.65436 & -5.66935 & 1.28484 \\
\hline $\mathrm{C}$ & -4.25566 & -5.74705 & -2.30029 \\
\hline $\mathrm{O}$ & -3.94807 & -3.69819 & -3.46824 \\
\hline $\mathrm{C}$ & 0.63961 & -5.74021 & 2.07047 \\
\hline $\mathrm{O}$ & -1.53482 & -6.49687 & 1.51269 \\
\hline $\mathrm{C}$ & 4.12577 & 4.66275 & -1.12383 \\
\hline $\mathrm{C}$ & 4.15147 & 3.25385 & -0.92470 \\
\hline $\mathrm{C}$ & 5.21684 & 2.51258 & -1.52680 \\
\hline $\mathrm{C}$ & 6.22831 & 3.19876 & -2.25157 \\
\hline $\mathrm{C}$ & 6.18228 & 4.56406 & -2.40851 \\
\hline
\end{tabular}




\begin{tabular}{|c|c|c|c|}
\hline $\mathrm{C}$ & 5.11085 & 5.29767 & -1.84712 \\
\hline $\mathrm{C}$ & 3.14751 & 2.54496 & -0.17802 \\
\hline $\mathrm{C}$ & 3.15198 & 1.15627 & -0.19197 \\
\hline $\mathrm{C}$ & 4.21901 & 0.40416 & -0.77237 \\
\hline $\mathrm{C}$ & 5.23348 & 1.10284 & -1.39518 \\
\hline $\mathrm{C}$ & 2.10737 & 3.28268 & 0.59190 \\
\hline $\mathrm{C}$ & 2.47759 & 4.23207 & 1.60616 \\
\hline $\mathrm{C}$ & 1.45964 & 5.04318 & 2.19925 \\
\hline $\mathrm{C}$ & 0.11876 & 4.87937 & 1.77520 \\
\hline $\mathrm{C}$ & -0.26210 & 3.90231 & 0.87694 \\
\hline $\mathrm{C}$ & 0.75906 & 3.06528 & 0.33316 \\
\hline $\mathrm{C}$ & 3.81110 & 4.38454 & 2.07911 \\
\hline $\mathrm{C}$ & 4.11791 & 5.30234 & 3.05896 \\
\hline $\mathrm{C}$ & 3.11266 & 6.12632 & 3.61768 \\
\hline $\mathrm{C}$ & 1.81079 & 5.99420 & 3.19494 \\
\hline $\mathrm{C}$ & 4.31356 & -1.09182 & -0.69640 \\
\hline $\mathrm{O}$ & 0.39782 & 2.07221 & -0.55900 \\
\hline $\mathrm{O}$ & 2.14573 & 0.47999 & 0.46800 \\
\hline $\mathrm{C}$ & -1.70798 & 3.83938 & 0.47442 \\
\hline $\mathrm{C}$ & 4.67047 & -1.71785 & 0.52103 \\
\hline $\mathrm{C}$ & 4.87784 & -3.10280 & 0.53564 \\
\hline $\mathrm{C}$ & 4.75782 & -3.89027 & -0.61136 \\
\hline $\mathrm{C}$ & 4.39319 & -3.25184 & -1.79945 \\
\hline $\mathrm{C}$ & 4.16457 & -1.87252 & -1.86996 \\
\hline $\mathrm{C}$ & -2.11619 & 4.38267 & -0.76715 \\
\hline $\mathrm{C}$ & -3.48490 & 4.50870 & -1.04016 \\
\hline $\mathrm{C}$ & -4.46698 & 4.11529 & -0.12623 \\
\hline $\mathrm{C}$ & -4.03702 & 3.53795 & 1.07172 \\
\hline $\mathrm{C}$ & -2.68266 & 3.39228 & 1.39707 \\
\hline $\mathrm{P}$ & 0.58571 & 0.47349 & -0.13049 \\
\hline $\mathrm{O}$ & -0.30909 & 0.07258 & 0.99923 \\
\hline $\mathrm{O}$ & 0.56313 & -0.29716 & -1.43621 \\
\hline $\mathrm{C}$ & -2.31444 & 2.77327 & 2.74541 \\
\hline $\mathrm{C}$ & -2.86057 & 1.34134 & 2.88295 \\
\hline $\mathrm{C}$ & -2.77144 & 3.65792 & 3.92131 \\
\hline $\mathrm{C}$ & -5.95373 & 4.37820 & -0.34847 \\
\hline $\mathrm{C}$ & -6.41970 & 4.23046 & -1.80533 \\
\hline $\mathrm{C}$ & -6.33022 & 5.77060 & 0.20094 \\
\hline $\mathrm{C}$ & -1.11486 & 4.87599 & -1.81147 \\
\hline $\mathrm{C}$ & -1.30820 & 6.36939 & -2.13693 \\
\hline $\mathrm{C}$ & -1.15967 & 4.01437 & -3.08766 \\
\hline $\mathrm{C}$ & 5.07302 & -5.38102 & -0.56492 \\
\hline $\mathrm{C}$ & 6.42760 & -5.68001 & -1.23734 \\
\hline $\mathrm{C}$ & 3.96139 & -6.25431 & -1.17260 \\
\hline $\mathrm{C}$ & 3.78882 & -1.26471 & -3.22295 \\
\hline $\mathrm{C}$ & 2.51772 & -1.89924 & -3.81538 \\
\hline
\end{tabular}




\begin{tabular}{|c|c|c|c|}
\hline $\mathrm{C}$ & 4.96001 & -1.35096 & -4.22135 \\
\hline $\mathrm{C}$ & 4.88735 & -0.93110 & 1.81357 \\
\hline $\mathrm{C}$ & 6.33643 & -1.06493 & 2.32071 \\
\hline $\mathrm{C}$ & 3.87515 & -1.32548 & 2.90517 \\
\hline $\mathrm{H}$ & -3.40794 & -1.30568 & 0.82786 \\
\hline $\mathrm{H}$ & -5.71864 & -4.03284 & 2.18455 \\
\hline $\mathrm{H}$ & -4.62092 & -5.35047 & 1.72643 \\
\hline $\mathrm{H}$ & -5.51335 & -4.47054 & 0.48937 \\
\hline $\mathrm{H}$ & -1.63786 & -1.70269 & 1.72205 \\
\hline $\mathrm{H}$ & -0.24156 & -1.50456 & 3.65616 \\
\hline $\mathrm{H}$ & -2.50121 & -4.56866 & 5.65955 \\
\hline $\mathrm{H}$ & -3.94899 & -4.77669 & 3.71335 \\
\hline $\mathrm{H}$ & -0.82851 & -2.14729 & 6.75265 \\
\hline $\mathrm{H}$ & 0.60730 & -2.50068 & 5.79235 \\
\hline $\mathrm{H}$ & -0.28085 & -3.81558 & 6.58490 \\
\hline $\mathrm{H}$ & -7.06195 & -0.32429 & -1.68551 \\
\hline $\mathrm{H}$ & -6.58953 & -1.89410 & -2.38325 \\
\hline $\mathrm{H}$ & -5.14889 & -0.78892 & -4.03194 \\
\hline $\mathrm{H}$ & -6.75492 & -0.01404 & -4.08702 \\
\hline $\mathrm{H}$ & -3.36766 & 0.43727 & -2.99997 \\
\hline $\mathrm{H}$ & -3.75411 & 2.01162 & -2.26415 \\
\hline $\mathrm{H}$ & -4.96280 & 0.98772 & -0.43713 \\
\hline $\mathrm{H}$ & -3.41700 & 0.14064 & -0.59467 \\
\hline $\mathrm{H}$ & -2.99933 & -4.11418 & 0.49112 \\
\hline $\mathrm{H}$ & -2.67192 & -5.71863 & -0.27390 \\
\hline $\mathrm{H}$ & -0.01384 & -1.82930 & -1.26906 \\
\hline $\mathrm{H}$ & -2.74146 & -1.69261 & -3.22507 \\
\hline $\mathrm{H}$ & -1.02772 & -1.20072 & -2.99628 \\
\hline $\mathrm{H}$ & -1.47990 & -2.58559 & -4.02651 \\
\hline $\mathrm{H}$ & 1.62672 & -2.30939 & -0.04171 \\
\hline $\mathrm{H}$ & 1.08828 & -2.88500 & 1.53615 \\
\hline $\mathrm{H}$ & 1.94083 & -3.97086 & 0.42988 \\
\hline $\mathrm{H}$ & -4.75437 & -5.79473 & -1.32690 \\
\hline $\mathrm{H}$ & -4.99475 & -5.89312 & -3.08845 \\
\hline $\mathrm{H}$ & -3.52956 & -6.56705 & -2.32546 \\
\hline $\mathrm{H}$ & 1.51141 & -5.83699 & 1.41695 \\
\hline $\mathrm{H}$ & 0.57989 & -6.61061 & 2.72457 \\
\hline $\mathrm{H}$ & 0.77921 & -4.84190 & 2.67882 \\
\hline $\mathrm{H}$ & 3.30909 & 5.24009 & -0.70806 \\
\hline $\mathrm{H}$ & 7.03458 & 2.61790 & -2.69212 \\
\hline $\mathrm{H}$ & 6.95612 & 5.07849 & -2.97057 \\
\hline $\mathrm{H}$ & 5.06162 & 6.37301 & -1.99190 \\
\hline $\mathrm{H}$ & 6.06867 & 0.55172 & -1.81826 \\
\hline $\mathrm{H}$ & -0.63993 & 5.54209 & 2.18209 \\
\hline $\mathrm{H}$ & 4.59180 & 3.75594 & 1.66817 \\
\hline $\mathrm{H}$ & 5.14210 & 5.39124 & 3.40957 \\
\hline
\end{tabular}




\begin{tabular}{|c|c|c|c|}
\hline $\mathrm{H}$ & 3.36986 & 6.85098 & 4.38458 \\
\hline $\mathrm{H}$ & 1.02401 & 6.60841 & 3.62533 \\
\hline $\mathrm{H}$ & 5.16591 & -3.58186 & 1.46879 \\
\hline $\mathrm{H}$ & 4.29451 & -3.84008 & -2.70771 \\
\hline $\mathrm{H}$ & -3.78589 & 4.95310 & -1.98406 \\
\hline $\mathrm{H}$ & -4.78668 & 3.21575 & 1.79153 \\
\hline $\mathrm{H}$ & -1.22567 & 2.69647 & 2.79229 \\
\hline $\mathrm{H}$ & -2.43317 & 0.70586 & 2.10467 \\
\hline $\mathrm{H}$ & -2.57459 & 0.91741 & 3.85176 \\
\hline $\mathrm{H}$ & -3.95451 & 1.31123 & 2.81966 \\
\hline $\mathrm{H}$ & -2.45568 & 3.21984 & 4.87456 \\
\hline $\mathrm{H}$ & -3.86224 & 3.75951 & 3.94789 \\
\hline $\mathrm{H}$ & -2.34723 & 4.66498 & 3.85624 \\
\hline $\mathrm{H}$ & -6.50055 & 3.63576 & 0.25001 \\
\hline $\mathrm{H}$ & -6.18179 & 3.24644 & -2.21909 \\
\hline $\mathrm{H}$ & -7.50470 & 4.37008 & -1.86541 \\
\hline $\mathrm{H}$ & -5.96549 & 4.98856 & -2.45275 \\
\hline $\mathrm{H}$ & -6.05331 & 5.87055 & 1.25483 \\
\hline $\mathrm{H}$ & -5.81066 & 6.55820 & -0.35609 \\
\hline $\mathrm{H}$ & -7.40801 & 5.94746 & 0.11105 \\
\hline $\mathrm{H}$ & -0.11145 & 4.77202 & -1.39217 \\
\hline $\mathrm{H}$ & -1.24676 & 6.98344 & -1.23277 \\
\hline $\mathrm{H}$ & -0.53324 & 6.71042 & -2.83210 \\
\hline $\mathrm{H}$ & -2.27894 & 6.56255 & -2.60620 \\
\hline $\mathrm{H}$ & -0.94706 & 2.96762 & -2.85434 \\
\hline $\mathrm{H}$ & -2.13937 & 4.07150 & -3.57619 \\
\hline $\mathrm{H}$ & -0.40988 & 4.35916 & -3.80836 \\
\hline $\mathrm{H}$ & 5.16555 & -5.65613 & 0.49442 \\
\hline $\mathrm{H}$ & 7.23246 & -5.09796 & -0.77843 \\
\hline $\mathrm{H}$ & 6.39953 & -5.42666 & -2.30280 \\
\hline $\mathrm{H}$ & 6.68101 & -6.74257 & -1.15075 \\
\hline $\mathrm{H}$ & 3.83731 & -6.06158 & -2.24343 \\
\hline $\mathrm{H}$ & 4.19982 & -7.31699 & -1.05626 \\
\hline $\mathrm{H}$ & 2.99537 & -6.07091 & -0.69064 \\
\hline $\mathrm{H}$ & 3.56536 & -0.20724 & -3.06560 \\
\hline $\mathrm{H}$ & 1.67270 & -1.74647 & -3.14188 \\
\hline $\mathrm{H}$ & 2.27529 & -1.42713 & -4.77404 \\
\hline $\mathrm{H}$ & 2.63990 & -2.97272 & -3.99881 \\
\hline $\mathrm{H}$ & 5.85832 & -0.86058 & -3.83345 \\
\hline $\mathrm{H}$ & 5.22154 & -2.39207 & -4.44186 \\
\hline $\mathrm{H}$ & 4.69337 & -0.86724 & -5.16746 \\
\hline $\mathrm{H}$ & 4.72464 & 0.12703 & 1.59577 \\
\hline $\mathrm{H}$ & 7.05408 & -0.75129 & 1.55599 \\
\hline $\mathrm{H}$ & 6.48984 & -0.43950 & 3.20702 \\
\hline $\mathrm{H}$ & 6.57577 & -2.09713 & 2.59890 \\
\hline $\mathrm{H}$ & 2.85288 & -1.14138 & 2.56486 \\
\hline
\end{tabular}




$\begin{array}{llll}\mathrm{H} & 3.96955 & -2.38292 & 3.17842 \\ \mathrm{H} & 4.04262 & -0.73313 & 3.81165\end{array}$

TS8-Z

B3LYP/6-31G(d,p) Energy = -3928.584013

B3LYP/6-31G(d,p) Free Energy = -3927.212778

Number of Imaginary Frequencies $=1(-903.17)$

$\begin{array}{lccc}\text { B3LYP/6-31G(d,p) Geometry } & \\ \mathrm{C} & 4.38726 & 0.63955 & -0.38634 \\ \mathrm{C} & 5.09382 & -0.26347 & -1.24764 \\ \mathrm{C} & 4.83548 & 1.03832 & 0.85869 \\ \mathrm{C} & 6.59760 & -0.34028 & -1.24607 \\ \mathrm{C} & 4.45988 & -0.48034 & -2.61762 \\ \mathrm{C} & 7.39197 & 0.78507 & -0.97436 \\ \mathrm{C} & 8.78332 & 0.71772 & -1.05109 \\ \mathrm{C} & 9.43536 & -0.46951 & -1.39912 \\ \mathrm{C} & 8.63968 & -1.58832 & -1.68911 \\ \mathrm{C} & 7.25124 & -1.52898 & -1.62295 \\ \mathrm{C} & 10.94131 & -0.55282 & -1.45337 \\ \mathrm{~N} & 4.21975 & 1.84953 & 1.73534 \\ \mathrm{C} & 4.76959 & 2.07967 & 3.07750 \\ \mathrm{C} & 4.68843 & 3.56670 & 3.42387 \\ \mathrm{O} & 3.35617 & 4.03795 & 3.30285 \\ \mathrm{C} & 2.88369 & 3.89074 & 1.96960 \\ \mathrm{C} & 2.88713 & 2.42900 & 1.52449 \\ \mathrm{H} & 5.80680 & 0.69204 & 1.19918 \\ \mathrm{C} & 4.31350 & -2.58024 & -0.03639 \\ \mathrm{C} & 3.22151 & -3.09974 & -0.87397 \\ \mathrm{C} & 1.93372 & -2.68390 & -0.59178 \\ \mathrm{~N} & 1.71654 & -1.95524 & 0.55732 \\ \mathrm{C} & 2.64615 & -1.71322 & 1.52143 \\ \mathrm{C} & 3.96858 & -2.08206 & 1.29193 \\ \mathrm{C} & 2.10171 & -1.10682 & 2.78356 \\ \mathrm{C} & 0.68862 & -2.87624 & -1.40414 \\ \mathrm{C} & 5.01362 & -1.95146 & 2.33871 \\ \mathrm{C} & 3.68126 & -3.95266 & -2.00166 \\ \mathrm{C} & 6.35505 & -2.63402 & 2.10453 \\ \mathrm{O} & 4.83614 & -1.32801 & 3.38388 \\ \mathrm{C} & 2.75758 & -4.84152 & -2.81504 \\ \mathrm{O} & 4.88582 & -3.97743 & -2.26274 \\ \mathrm{C} & -6.57305 & 1.19656 & 1.09306 \\ \mathrm{C} & -5.75927 & 0.05226 & 0.86221 \\ \mathrm{C} & -6.15648 & -1.18430 & 1.46454 \\ \mathrm{C} & -7.35776 & -1.24161 & 2.22134\end{array}$




\begin{tabular}{|c|c|c|c|}
\hline $\mathrm{C}$ & -8.13055 & -0.11954 & 2.40841 \\
\hline $\mathrm{C}$ & -7.72311 & 1.11291 & 1.84622 \\
\hline $\mathrm{C}$ & -4.55218 & 0.08936 & 0.08188 \\
\hline $\mathrm{C}$ & -3.73287 & -1.03167 & 0.06153 \\
\hline $\mathrm{C}$ & -4.12105 & -2.27516 & 0.64721 \\
\hline $\mathrm{C}$ & -5.33270 & -2.32600 & 1.30508 \\
\hline $\mathrm{C}$ & -4.16659 & 1.30683 & -0.68668 \\
\hline $\mathrm{C}$ & -5.04425 & 1.86695 & -1.67852 \\
\hline $\mathrm{C}$ & -4.69524 & 3.11390 & -2.28717 \\
\hline $\mathrm{C}$ & -3.49617 & 3.75853 & -1.89574 \\
\hline $\mathrm{C}$ & -2.60277 & 3.18717 & -1.01221 \\
\hline $\mathrm{C}$ & -2.93805 & 1.91561 & -0.45835 \\
\hline $\mathrm{C}$ & -6.23240 & 1.21976 & -2.11961 \\
\hline $\mathrm{C}$ & -7.03695 & 1.78780 & -3.08226 \\
\hline $\mathrm{C}$ & -6.70537 & 3.03786 & -3.65548 \\
\hline $\mathrm{C}$ & -5.55542 & 3.68279 & -3.26451 \\
\hline $\mathrm{C}$ & -3.27411 & -3.50891 & 0.54577 \\
\hline $\mathrm{O}$ & -2.03719 & 1.30866 & 0.39923 \\
\hline $\mathrm{O}$ & -2.55091 & -0.98548 & -0.64232 \\
\hline $\mathrm{C}$ & -1.39397 & 3.98821 & -0.61477 \\
\hline $\mathrm{C}$ & -3.16733 & -4.19896 & -0.68694 \\
\hline $\mathrm{C}$ & -2.43272 & -5.38835 & -0.73865 \\
\hline $\mathrm{C}$ & -1.80904 & -5.92940 & 0.39044 \\
\hline $\mathrm{C}$ & -1.92524 & -5.22991 & 1.59106 \\
\hline $\mathrm{C}$ & -2.64232 & -4.03098 & 1.69862 \\
\hline $\mathrm{C}$ & -0.29789 & 4.12504 & -1.49958 \\
\hline $\mathrm{C}$ & 0.69527 & 5.06416 & -1.19908 \\
\hline $\mathrm{C}$ & 0.64651 & 5.87708 & -0.06118 \\
\hline $\mathrm{C}$ & -0.40979 & 5.67499 & 0.82920 \\
\hline $\mathrm{C}$ & -1.43014 & 4.74643 & 0.57768 \\
\hline $\mathrm{P}$ & -1.25659 & -0.05750 & -0.14500 \\
\hline $\mathrm{O}$ & -0.43550 & 0.19794 & -1.36809 \\
\hline $\mathrm{O}$ & -0.62108 & -0.68520 & 1.07954 \\
\hline $\mathrm{C}$ & -2.55530 & 4.60262 & 1.60185 \\
\hline $\mathrm{C}$ & -3.26645 & 5.93875 & 1.88614 \\
\hline $\mathrm{C}$ & -2.04039 & 3.95315 & 2.90106 \\
\hline $\mathrm{C}$ & 1.69091 & 6.97764 & 0.11809 \\
\hline $\mathrm{C}$ & 1.85295 & 7.48784 & 1.55759 \\
\hline $\mathrm{C}$ & 1.38330 & 8.15793 & -0.82844 \\
\hline $\mathrm{C}$ & -0.18402 & 3.30976 & -2.78788 \\
\hline $\mathrm{C}$ & 1.15569 & 2.55730 & -2.88345 \\
\hline $\mathrm{C}$ & -0.40976 & 4.19277 & -4.03074 \\
\hline $\mathrm{C}$ & -1.04632 & -7.24701 & 0.33051 \\
\hline $\mathrm{C}$ & 0.19405 & -7.15719 & -0.57732 \\
\hline $\mathrm{C}$ & -1.95269 & -8.41848 & -0.09115 \\
\hline $\mathrm{C}$ & -2.71527 & -3.35019 & 3.06591 \\
\hline
\end{tabular}




\begin{tabular}{|c|c|c|c|}
\hline $\mathrm{C}$ & -1.31901 & -2.98057 & 3.59786 \\
\hline $\mathrm{C}$ & -3.48930 & -4.20949 & 4.08421 \\
\hline $\mathrm{C}$ & -3.87722 & -3.72166 & -1.95416 \\
\hline $\mathrm{C}$ & -4.94407 & -4.73568 & -2.41199 \\
\hline $\mathrm{C}$ & -2.88971 & -3.40010 & -3.09072 \\
\hline $\mathrm{H}$ & 3.38097 & 0.90203 & -0.69637 \\
\hline $\mathrm{H}$ & 4.86740 & -1.36324 & -3.11199 \\
\hline $\mathrm{H}$ & 4.67248 & 0.38908 & -3.25099 \\
\hline $\mathrm{H}$ & 3.37380 & -0.58237 & -2.54207 \\
\hline $\mathrm{H}$ & 6.91747 & 1.73114 & -0.73674 \\
\hline $\mathrm{H}$ & 9.36964 & 1.60988 & -0.84593 \\
\hline $\mathrm{H}$ & 9.11603 & -2.52184 & -1.97828 \\
\hline $\mathrm{H}$ & 6.66537 & -2.41121 & -1.86653 \\
\hline $\mathrm{H}$ & 11.27829 & -1.13426 & -2.31731 \\
\hline $\mathrm{H}$ & 11.34256 & -1.04422 & -0.55839 \\
\hline $\mathrm{H}$ & 11.39574 & 0.43983 & -1.51409 \\
\hline $\mathrm{H}$ & 5.80203 & 1.72286 & 3.10719 \\
\hline $\mathrm{H}$ & 4.19427 & 1.50163 & 3.81038 \\
\hline $\mathrm{H}$ & 4.99157 & 3.72715 & 4.46211 \\
\hline $\mathrm{H}$ & 5.36176 & 4.14184 & 2.76680 \\
\hline $\mathrm{H}$ & 1.86436 & 4.27776 & 1.94239 \\
\hline $\mathrm{H}$ & 3.50426 & 4.48665 & 1.28162 \\
\hline $\mathrm{H}$ & 2.61175 & 2.37287 & 0.47155 \\
\hline $\mathrm{H}$ & 2.14894 & 1.85969 & 2.10203 \\
\hline $\mathrm{H}$ & 4.75594 & -1.53213 & -0.66672 \\
\hline $\mathrm{H}$ & 5.21882 & -3.17794 & -0.10972 \\
\hline $\mathrm{H}$ & 0.75566 & -1.54336 & 0.71545 \\
\hline $\mathrm{H}$ & 2.74734 & -0.30536 & 3.13449 \\
\hline $\mathrm{H}$ & 1.08306 & -0.75136 & 2.62325 \\
\hline $\mathrm{H}$ & 2.09920 & -1.85715 & 3.58212 \\
\hline $\mathrm{H}$ & -0.07369 & -3.40971 & -0.82646 \\
\hline $\mathrm{H}$ & 0.27980 & -1.88519 & -1.64567 \\
\hline $\mathrm{H}$ & 0.86357 & -3.41104 & -2.32989 \\
\hline $\mathrm{H}$ & 6.96459 & -2.49474 & 2.99776 \\
\hline $\mathrm{H}$ & 6.22782 & -3.70572 & 1.91550 \\
\hline $\mathrm{H}$ & 6.88019 & -2.21440 & 1.24008 \\
\hline $\mathrm{H}$ & 1.96676 & -5.29953 & -2.21824 \\
\hline $\mathrm{H}$ & 3.37493 & -5.61623 & -3.27278 \\
\hline $\mathrm{H}$ & 2.28841 & -4.26925 & -3.62318 \\
\hline $\mathrm{H}$ & -6.27252 & 2.15019 & 0.67630 \\
\hline $\mathrm{H}$ & -7.64724 & -2.19225 & 2.66194 \\
\hline $\mathrm{H}$ & -9.04324 & -0.17305 & 2.99457 \\
\hline $\mathrm{H}$ & -8.32092 & 2.00415 & 2.01397 \\
\hline $\mathrm{H}$ & -5.65947 & -3.26775 & 1.73763 \\
\hline $\mathrm{H}$ & -3.27226 & 4.73741 & -2.31058 \\
\hline $\mathrm{H}$ & -6.49651 & 0.25739 & -1.69836 \\
\hline
\end{tabular}




\begin{tabular}{|c|c|c|c|}
\hline $\mathrm{H}$ & -7.93305 & 1.26765 & -3.40823 \\
\hline $\mathrm{H}$ & -7.35231 & 3.47769 & -4.40881 \\
\hline $\mathrm{H}$ & -5.27790 & 4.63611 & -3.70694 \\
\hline $\mathrm{H}$ & -2.36747 & -5.91847 & -1.68550 \\
\hline $\mathrm{H}$ & -1.44758 & -5.63736 & 2.47903 \\
\hline $\mathrm{H}$ & 1.52316 & 5.19103 & -1.89360 \\
\hline $\mathrm{H}$ & -0.46446 & 6.26931 & 1.73548 \\
\hline $\mathrm{H}$ & -3.30647 & 3.92820 & 1.18388 \\
\hline $\mathrm{H}$ & -3.65100 & 6.38739 & 0.96463 \\
\hline $\mathrm{H}$ & -4.11154 & 5.78160 & 2.56523 \\
\hline $\mathrm{H}$ & -2.59814 & 6.66680 & 2.35858 \\
\hline $\mathrm{H}$ & -1.60450 & 2.97177 & 2.69516 \\
\hline $\mathrm{H}$ & -1.27853 & 4.57581 & 3.38428 \\
\hline $\mathrm{H}$ & -2.86129 & 3.81790 & 3.61411 \\
\hline $\mathrm{H}$ & 2.65774 & 6.55715 & -0.19557 \\
\hline $\mathrm{H}$ & 0.94825 & 7.99759 & 1.90636 \\
\hline $\mathrm{H}$ & 2.67003 & 8.21512 & 1.60630 \\
\hline $\mathrm{H}$ & 2.07959 & 6.68413 & 2.26442 \\
\hline $\mathrm{H}$ & 0.42565 & 8.62058 & -0.56537 \\
\hline $\mathrm{H}$ & 2.16159 & 8.92644 & -0.76050 \\
\hline $\mathrm{H}$ & 1.31802 & 7.82869 & -1.86946 \\
\hline $\mathrm{H}$ & -0.96249 & 2.54367 & -2.76949 \\
\hline $\mathrm{H}$ & 1.24317 & 1.84897 & -2.05631 \\
\hline $\mathrm{H}$ & 1.19216 & 1.98029 & -3.81410 \\
\hline $\mathrm{H}$ & 2.01470 & 3.23864 & -2.88387 \\
\hline $\mathrm{H}$ & -1.38639 & 4.68581 & -4.00080 \\
\hline $\mathrm{H}$ & 0.35447 & 4.97471 & -4.11007 \\
\hline $\mathrm{H}$ & -0.36589 & 3.58865 & -4.94370 \\
\hline $\mathrm{H}$ & -0.69114 & -7.45726 & 1.34802 \\
\hline $\mathrm{H}$ & 0.86714 & -6.36125 & -0.24190 \\
\hline $\mathrm{H}$ & -0.08999 & -6.94638 & -1.61451 \\
\hline $\mathrm{H}$ & 0.75287 & -8.09962 & -0.57078 \\
\hline $\mathrm{H}$ & -2.33058 & -8.28299 & -1.11029 \\
\hline $\mathrm{H}$ & -1.40164 & -9.36515 & -0.06424 \\
\hline $\mathrm{H}$ & -2.81660 & -8.50726 & 0.57439 \\
\hline $\mathrm{H}$ & -3.26241 & -2.41262 & 2.94635 \\
\hline $\mathrm{H}$ & -0.82127 & -2.30838 & 2.89620 \\
\hline $\mathrm{H}$ & -1.40630 & -2.46788 & 4.56262 \\
\hline $\mathrm{H}$ & -0.69220 & -3.86685 & 3.75086 \\
\hline $\mathrm{H}$ & -4.50089 & -4.43681 & 3.73247 \\
\hline $\mathrm{H}$ & -2.98343 & -5.16317 & 4.27216 \\
\hline $\mathrm{H}$ & -3.57444 & -3.68429 & 5.04196 \\
\hline $\mathrm{H}$ & -4.40330 & -2.79390 & -1.71749 \\
\hline $\mathrm{H}$ & -5.66905 & -4.93474 & -1.61632 \\
\hline $\mathrm{H}$ & -5.48992 & -4.35071 & -3.28045 \\
\hline $\mathrm{H}$ & -4.49513 & -5.69264 & -2.70012 \\
\hline
\end{tabular}




$\begin{array}{llll}\mathrm{H} & -2.19138 & -2.61722 & -2.78520 \\ \mathrm{H} & -2.31640 & -4.28535 & -3.38998 \\ \mathrm{H} & -3.43044 & -3.04427 & -3.97475\end{array}$

\section{TS5-E}

B3LYP-D3/6-31G(d) Energy $=-3928.747719$

B3LYP-D3/6-31G(d) Free Energy $=-3927.354453$

Number of Imaginary Frequencies $=1(-1147.77)$

$\begin{array}{lccc}\text { B3LYP-D } 3 / 6-31 G(d) \text { Geometry } & \\ \text { C } & 3.84025 & 1.36362 & 1.25110 \\ \text { C } & 4.51611 & 0.28246 & 0.59513 \\ \text { C } & 2.46870 & 1.44312 & 1.40450 \\ \text { C } & 5.98903 & 0.15851 & 0.88519 \\ \text { C } & 3.80295 & -1.05114 & 0.39924 \\ \text { C } & 6.87914 & -0.35042 & -0.07426 \\ \text { C } & 8.23222 & -0.49609 & 0.21896 \\ \text { C } & 8.75004 & -0.14926 & 1.47455 \\ \text { C } & 7.85864 & 0.34581 & 2.43307 \\ \text { C } & 6.50308 & 0.50113 & 2.14586 \\ \text { C } & 10.22474 & -0.28305 & 1.77071 \\ \text { N } & 1.77079 & 2.46006 & 1.93912 \\ \text { C } & 2.36948 & 3.65735 & 2.53271 \\ \text { C } & 2.33379 & 3.51939 & 4.05912 \\ \text { O } & 1.00647 & 3.30267 & 4.51446 \\ \text { C } & 0.42450 & 2.13865 & 3.93091 \\ \text { C } & 0.39045 & 2.24310 & 2.40295 \\ \text { H } & 1.83133 & 0.63243 & 1.06346 \\ \text { C } & 4.20977 & 1.15737 & -1.95154 \\ \text { C } & 3.34953 & 2.27764 & -1.59163 \\ \text { C } & 1.97501 & 2.10445 & -1.68858 \\ \text { N } & 1.49594 & 0.94893 & -2.22174 \\ \text { C } & 2.24837 & -0.04983 & -2.77406 \\ \text { C } & 3.62425 & 0.07136 & -2.74639 \\ \text { C } & 1.43032 & -1.19534 & -3.31390 \\ \text { C } & 0.92644 & 3.08453 & -1.26388 \\ \text { C } & 4.59033 & -0.83046 & -3.41633 \\ \text { C } & 3.93637 & 3.49796 & -0.98557 \\ \text { C } & 4.17984 & -1.73686 & -4.56474 \\ \text { O } & 5.77515 & -0.79591 & -3.08521 \\ \text { C } & 5.45496 & 3.59142 & -0.92338 \\ \text { O } & 3.25151 & 4.41743 & -0.54119 \\ \text { C } & -6.34232 & -2.14034 & -1.02495 \\ \text { C } & -5.63263 & -0.92829 & -0.80282 \\ \text { C } & -6.19906 & 0.28818 & -1.30559 \\ & & & \end{array}$




\begin{tabular}{|c|c|c|c|}
\hline $\mathrm{C}$ & -7.46241 & 0.25192 & -1.95427 \\
\hline $\mathrm{C}$ & -8.13366 & -0.93594 & -2.13231 \\
\hline $\mathrm{C}$ & -7.55832 & -2.14391 & -1.67198 \\
\hline $\mathrm{C}$ & -4.36351 & -0.87966 & -0.13099 \\
\hline $\mathrm{C}$ & -3.67313 & 0.32343 & -0.11932 \\
\hline $\mathrm{C}$ & -4.22229 & 1.54357 & -0.60685 \\
\hline $\mathrm{C}$ & -5.48351 & 1.50450 & -1.15894 \\
\hline $\mathrm{C}$ & -3.76161 & -2.07124 & 0.53102 \\
\hline $\mathrm{C}$ & -4.45077 & -2.80447 & 1.55760 \\
\hline $\mathrm{C}$ & -3.83670 & -3.97990 & 2.10238 \\
\hline $\mathrm{C}$ & -2.53622 & -4.35014 & 1.67447 \\
\hline $\mathrm{C}$ & -1.82499 & -3.58914 & 0.77294 \\
\hline $\mathrm{C}$ & -2.47032 & -2.45702 & 0.20182 \\
\hline $\mathrm{C}$ & -5.70784 & -2.40161 & 2.08802 \\
\hline $\mathrm{C}$ & -6.34002 & -3.14190 & 3.06247 \\
\hline $\mathrm{C}$ & -5.75171 & -4.32670 & 3.56462 \\
\hline $\mathrm{C}$ & -4.52285 & -4.72954 & 3.09538 \\
\hline $\mathrm{C}$ & -3.45461 & 2.81801 & -0.44849 \\
\hline $\mathrm{O}$ & -1.78152 & -1.76290 & -0.77223 \\
\hline $\mathrm{O}$ & -2.40727 & 0.37167 & 0.44469 \\
\hline $\mathrm{C}$ & -0.40472 & -3.89659 & 0.42156 \\
\hline $\mathrm{C}$ & -3.32662 & 3.37880 & 0.84023 \\
\hline $\mathrm{C}$ & -2.57108 & 4.54584 & 0.99975 \\
\hline $\mathrm{C}$ & -1.97006 & 5.19479 & -0.08034 \\
\hline $\mathrm{C}$ & -2.14471 & 4.64064 & -1.35250 \\
\hline $\mathrm{C}$ & -2.86450 & 3.45876 & -1.56296 \\
\hline $\mathrm{C}$ & 0.61679 & -3.64303 & 1.36357 \\
\hline $\mathrm{C}$ & 1.93817 & -3.94515 & 1.01577 \\
\hline $\mathrm{C}$ & 2.28311 & -4.45675 & -0.23555 \\
\hline $\mathrm{C}$ & 1.25458 & -4.68633 & -1.15428 \\
\hline $\mathrm{C}$ & -0.08408 & -4.42347 & -0.84827 \\
\hline $\mathrm{P}$ & -1.16580 & -0.25876 & -0.45674 \\
\hline $\mathrm{O}$ & 0.04288 & -0.30315 & 0.42831 \\
\hline $\mathrm{O}$ & -1.09419 & 0.41222 & -1.81096 \\
\hline $\mathrm{C}$ & -1.15970 & -4.75905 & -1.87767 \\
\hline $\mathrm{C}$ & -1.18403 & -6.27007 & -2.17652 \\
\hline $\mathrm{C}$ & -1.00428 & -3.93522 & -3.16762 \\
\hline $\mathrm{C}$ & 3.72948 & -4.80066 & -0.55988 \\
\hline $\mathrm{C}$ & 4.19538 & -4.19031 & -1.89146 \\
\hline $\mathrm{C}$ & 3.94495 & -6.32598 & -0.55363 \\
\hline $\mathrm{C}$ & 0.32392 & -3.08172 & 2.75377 \\
\hline $\mathrm{C}$ & 1.21039 & -1.87637 & 3.11149 \\
\hline $\mathrm{C}$ & 0.44386 & -4.18623 & 3.82079 \\
\hline $\mathrm{C}$ & -1.23109 & 6.51084 & 0.12380 \\
\hline $\mathrm{C}$ & -2.03758 & 7.67851 & -0.47773 \\
\hline $\mathrm{C}$ & 0.20294 & 6.49900 & -0.43223 \\
\hline
\end{tabular}




\begin{tabular}{|c|c|c|c|}
\hline $\mathrm{C}$ & -3.06946 & 2.94593 & -2.98786 \\
\hline $\mathrm{C}$ & -1.78559 & 2.90647 & -3.83302 \\
\hline $\mathrm{C}$ & -4.14634 & 3.79432 & -3.69466 \\
\hline $\mathrm{C}$ & -4.04640 & 2.79086 & 2.05180 \\
\hline $\mathrm{C}$ & -5.07155 & 3.79052 & 2.61998 \\
\hline $\mathrm{C}$ & -3.06690 & 2.31848 & 3.13692 \\
\hline $\mathrm{H}$ & 4.46011 & 2.18724 & 1.58863 \\
\hline $\mathrm{H}$ & 3.76431 & -1.58318 & 1.35497 \\
\hline $\mathrm{H}$ & 4.35798 & -1.67504 & -0.30487 \\
\hline $\mathrm{H}$ & 2.77725 & -0.94705 & 0.03630 \\
\hline $\mathrm{H}$ & 6.51605 & -0.61145 & -1.06338 \\
\hline $\mathrm{H}$ & 8.90042 & -0.88450 & -0.54662 \\
\hline $\mathrm{H}$ & 8.22684 & 0.60807 & 3.42256 \\
\hline $\mathrm{H}$ & 5.83121 & 0.86297 & 2.91880 \\
\hline $\mathrm{H}$ & 10.41387 & -0.36356 & 2.84636 \\
\hline $\mathrm{H}$ & 10.78167 & 0.58991 & 1.40471 \\
\hline $\mathrm{H}$ & 10.65256 & -1.16614 & 1.28336 \\
\hline $\mathrm{H}$ & 1.76223 & 4.51611 & 2.22634 \\
\hline $\mathrm{H}$ & 3.37677 & 3.81759 & 2.14978 \\
\hline $\mathrm{H}$ & 2.98931 & 2.68579 & 4.36501 \\
\hline $\mathrm{H}$ & 2.68464 & 4.43742 & 4.54029 \\
\hline $\mathrm{H}$ & 0.99497 & 1.23910 & 4.21795 \\
\hline $\mathrm{H}$ & -0.58377 & 2.05938 & 4.34058 \\
\hline $\mathrm{H}$ & -0.22292 & 3.09736 & 2.09473 \\
\hline $\mathrm{H}$ & -0.01003 & 1.33958 & 1.93927 \\
\hline $\mathrm{H}$ & 4.50596 & 0.66582 & -0.74265 \\
\hline $\mathrm{H}$ & 5.23896 & 1.38313 & -2.22544 \\
\hline $\mathrm{H}$ & 0.46286 & 0.78097 & -2.13261 \\
\hline $\mathrm{H}$ & 1.74216 & -2.14262 & -2.86348 \\
\hline $\mathrm{H}$ & 0.37661 & -1.04434 & -3.07587 \\
\hline $\mathrm{H}$ & 1.52051 & -1.28533 & -4.39972 \\
\hline $\mathrm{H}$ & -0.07304 & 2.67177 & -1.39209 \\
\hline $\mathrm{H}$ & 1.07336 & 3.36157 & -0.22067 \\
\hline $\mathrm{H}$ & 1.01692 & 4.01043 & -1.83663 \\
\hline $\mathrm{H}$ & 5.09214 & -2.12003 & -5.02563 \\
\hline $\mathrm{H}$ & 3.58366 & -2.58369 & -4.21451 \\
\hline $\mathrm{H}$ & 3.58766 & -1.19661 & -5.31085 \\
\hline $\mathrm{H}$ & 5.72106 & 4.51811 & -0.41192 \\
\hline $\mathrm{H}$ & 5.88412 & 3.60412 & -1.93343 \\
\hline $\mathrm{H}$ & 5.89984 & 2.74024 & -0.39600 \\
\hline $\mathrm{H}$ & -5.90907 & -3.07380 & -0.68446 \\
\hline $\mathrm{H}$ & -7.88348 & 1.18528 & -2.32091 \\
\hline $\mathrm{H}$ & -9.09638 & -0.95148 & -2.63591 \\
\hline $\mathrm{H}$ & -8.07795 & -3.08428 & -1.83501 \\
\hline $\mathrm{H}$ & -5.94027 & 2.42605 & -1.50877 \\
\hline $\mathrm{H}$ & -2.07463 & -5.23581 & 2.10293 \\
\hline
\end{tabular}




\begin{tabular}{|c|c|c|c|}
\hline $\mathrm{H}$ & -6.16876 & -1.49234 & 1.72064 \\
\hline $\mathrm{H}$ & -7.29784 & -2.80891 & 3.45317 \\
\hline $\mathrm{H}$ & -6.26398 & -4.90517 & 4.32857 \\
\hline $\mathrm{H}$ & -4.04650 & -5.62432 & 3.48956 \\
\hline $\mathrm{H}$ & -2.47331 & 4.98168 & 1.99219 \\
\hline $\mathrm{H}$ & -1.71087 & 5.14783 & -2.20985 \\
\hline $\mathrm{H}$ & 2.72756 & -3.77538 & 1.74378 \\
\hline $\mathrm{H}$ & 1.49591 & -5.10479 & -2.12838 \\
\hline $\mathrm{H}$ & -2.13299 & -4.50281 & -1.44904 \\
\hline $\mathrm{H}$ & -1.32487 & -6.85057 & -1.25784 \\
\hline $\mathrm{H}$ & -2.00267 & -6.51233 & -2.86482 \\
\hline $\mathrm{H}$ & -0.24796 & -6.60248 & -2.64108 \\
\hline $\mathrm{H}$ & -1.08124 & -2.86793 & -2.94692 \\
\hline $\mathrm{H}$ & -0.03820 & -4.12651 & -3.65162 \\
\hline $\mathrm{H}$ & -1.79207 & -4.19541 & -3.88486 \\
\hline $\mathrm{H}$ & 4.35459 & -4.37132 & 0.23511 \\
\hline $\mathrm{H}$ & 4.02424 & -3.11024 & -1.90663 \\
\hline $\mathrm{H}$ & 5.26542 & -4.36455 & -2.05179 \\
\hline $\mathrm{H}$ & 3.65818 & -4.62953 & -2.74072 \\
\hline $\mathrm{H}$ & 3.65781 & -6.75915 & 0.41055 \\
\hline $\mathrm{H}$ & 3.33527 & -6.80490 & -1.32939 \\
\hline $\mathrm{H}$ & 4.99577 & -6.57499 & -0.74562 \\
\hline $\mathrm{H}$ & -0.70834 & -2.72168 & 2.76112 \\
\hline $\mathrm{H}$ & 1.11188 & -1.10707 & 2.34456 \\
\hline $\mathrm{H}$ & 0.89757 & -1.45681 & 4.07625 \\
\hline $\mathrm{H}$ & 2.26724 & -2.15351 & 3.20657 \\
\hline $\mathrm{H}$ & -0.23230 & -5.02191 & 3.61040 \\
\hline $\mathrm{H}$ & 1.46506 & -4.58555 & 3.85503 \\
\hline $\mathrm{H}$ & 0.20073 & -3.79282 & 4.81537 \\
\hline $\mathrm{H}$ & -1.16333 & 6.68040 & 1.20767 \\
\hline $\mathrm{H}$ & -3.04839 & 7.71737 & -0.05725 \\
\hline $\mathrm{H}$ & -2.13221 & 7.56521 & -1.56444 \\
\hline $\mathrm{H}$ & -1.54334 & 8.63755 & -0.28048 \\
\hline $\mathrm{H}$ & 0.20742 & 6.33979 & -1.51710 \\
\hline $\mathrm{H}$ & 0.69435 & 7.46050 & -0.24150 \\
\hline $\mathrm{H}$ & 0.81598 & 5.71259 & 0.01753 \\
\hline $\mathrm{H}$ & -3.43229 & 1.91667 & -2.92503 \\
\hline $\mathrm{H}$ & -1.05764 & 2.22690 & -3.38915 \\
\hline $\mathrm{H}$ & -2.01938 & 2.53942 & -4.83966 \\
\hline $\mathrm{H}$ & -1.32948 & 3.89722 & -3.94633 \\
\hline $\mathrm{H}$ & -5.08600 & 3.80448 & -3.13234 \\
\hline $\mathrm{H}$ & -3.81318 & 4.83447 & -3.79881 \\
\hline $\mathrm{H}$ & -4.35316 & 3.40209 & -4.69783 \\
\hline $\mathrm{H}$ & -4.60896 & 1.91286 & 1.72364 \\
\hline $\mathrm{H}$ & -5.78567 & 4.10091 & 1.84906 \\
\hline $\mathrm{H}$ & -5.63293 & 3.33598 & 3.44520 \\
\hline
\end{tabular}




$\begin{array}{llll}\mathrm{H} & -4.58239 & 4.69276 & 3.00558 \\ \mathrm{H} & -2.39193 & 1.56000 & 2.73099 \\ \mathrm{H} & -2.47051 & 3.15441 & 3.52201 \\ \mathrm{H} & -3.61061 & 1.88014 & 3.98260\end{array}$

\section{TS5-Z}

B3LYP-D3/6-31G(d) Energy $=-3928.746788$

B3LYP-D3/6-31G(d) Free Energy $=-3927.353095$

Number of Imaginary Frequencies $=1(-1107.42)$

$\begin{array}{lrrr}\text { B3LYP-D3/6-31G(d) Geometry } & \\ \text { C } & 1.44077 & 3.47471 & 2.74206 \\ \text { C } & 2.40995 & 4.14993 & 1.90427 \\ \text { C } & 1.13895 & 2.12918 & 2.72257 \\ \text { N } & 0.27393 & 1.46389 & 3.51338 \\ \text { C } & -0.45940 & 2.05541 & 4.62973 \\ \text { C } & -1.89230 & 1.51153 & 4.65475 \\ \text { O } & -1.93322 & 0.09746 & 4.65608 \\ \text { C } & -1.27095 & -0.43992 & 3.50748 \\ \text { C } & 0.19134 & -0.00574 & 3.46750 \\ \text { H } & 1.61918 & 1.48056 & 2.00709 \\ \text { C } & 0.79383 & 5.12572 & -0.05229 \\ \text { C } & -0.43804 & 4.51481 & 0.44040 \\ \text { C } & -0.85133 & 3.32662 & -0.13711 \\ \text { N } & -0.20706 & 2.88382 & -1.25747 \\ \text { C } & 0.79861 & 3.54132 & -1.91054 \\ \text { C } & 1.29292 & 4.70989 & -1.35874 \\ \text { C } & 1.28264 & 2.86313 & -3.15916 \\ \text { C } & -1.91895 & 2.40079 & 0.35659 \\ \text { C } & 2.38065 & 5.46255 & -2.03547 \\ \text { C } & -1.01096 & 5.17553 & 1.63895 \\ \text { C } & 3.15208 & 6.48757 & -1.22058 \\ \text { O } & 2.68291 & 5.25592 & -3.20517 \\ \text { C } & -2.34716 & 4.77723 & 2.24151 \\ \text { O } & -0.38689 & 6.10246 & 2.15684 \\ \text { C } & -1.95095 & -4.69764 & 2.43944 \\ \text { C } & -0.78052 & -4.29884 & 1.73646 \\ \text { C } & 0.49148 & -4.72490 & 2.23685 \\ \text { C } & 0.54263 & -5.55947 & 3.38577 \\ \text { C } & -0.60919 & -5.93670 & 4.03732 \\ \text { C } & -1.86620 & -5.49070 & 3.56265 \\ \text { C } & -0.82014 & -3.46338 & 0.57154 \\ \text { C } & 0.37215 & -2.95652 & 0.07465 \\ \text { C } & 1.64649 & -3.39927 & 0.52941 \\ \text { C } & 1.67059 & -4.29974 & 1.57636 \\ \text { C } & -2.09511 & -3.14443 & -0.12434 \\ & & & \end{array}$




\begin{tabular}{|c|c|c|c|}
\hline $\mathrm{C}$ & -2.93867 & -4.18621 & -0.64127 \\
\hline $\mathrm{C}$ & -4.18709 & -3.82843 & -1.24392 \\
\hline $\mathrm{C}$ & -4.53477 & -2.45888 & -1.35176 \\
\hline $\mathrm{C}$ & -3.68827 & -1.45155 & -0.94116 \\
\hline $\mathrm{C}$ & -2.45398 & -1.82152 & -0.33384 \\
\hline $\mathrm{C}$ & -2.58227 & -5.56332 & -0.61055 \\
\hline $\mathrm{C}$ & -3.42910 & -6.52751 & -1.11074 \\
\hline $\mathrm{C}$ & -4.67940 & -6.17218 & -1.67022 \\
\hline $\mathrm{C}$ & -5.04434 & -4.84761 & -1.73802 \\
\hline $\mathrm{C}$ & 2.92284 & -2.96151 & -0.11384 \\
\hline $\mathrm{O}$ & -1.62980 & -0.82049 & 0.14362 \\
\hline $\mathrm{O}$ & 0.32834 & -2.04099 & -0.96227 \\
\hline $\mathrm{C}$ & -4.10613 & -0.02071 & -1.08004 \\
\hline $\mathrm{C}$ & 3.90391 & -2.28479 & 0.65053 \\
\hline $\mathrm{C}$ & 5.14522 & -2.01216 & 0.06704 \\
\hline $\mathrm{C}$ & 5.45566 & -2.38603 & -1.24280 \\
\hline $\mathrm{C}$ & 4.45580 & -3.00780 & -1.99158 \\
\hline $\mathrm{C}$ & 3.19680 & -3.30564 & -1.45821 \\
\hline $\mathrm{C}$ & -3.87506 & 0.68038 & -2.28594 \\
\hline $\mathrm{C}$ & -4.32407 & 2.00087 & -2.38477 \\
\hline $\mathrm{C}$ & -4.99983 & 2.63938 & -1.34073 \\
\hline $\mathrm{C}$ & -5.22543 & & -0.16625 \\
\hline $\mathrm{C}$ & -4.77048 & 0.60605 & -0.00539 \\
\hline$P$ & -0.15932 & -0.50094 & -0.59861 \\
\hline $\mathrm{O}$ & -0.40286 & 0.20037 & -1.91076 \\
\hline $\mathrm{O}$ & 0.69746 & 0.12977 & 0.45619 \\
\hline $\mathrm{C}$ & -4.98755 & -0.12467 & 1.31679 \\
\hline $\mathrm{C}$ & -6.35748 & -0.82744 & 1.34395 \\
\hline $\mathrm{C}$ & -4.82022 & 0.79161 & 2.54025 \\
\hline $\mathrm{C}$ & -5.43911 & 4.09069 & -1.46682 \\
\hline $\mathrm{C}$ & -6.48160 & 4.27639 & -2.58408 \\
\hline $\mathrm{C}$ & -4.23360 & 5.02626 & -1.68240 \\
\hline $\mathrm{C}$ & -3.17130 & 0.01983 & -3.46819 \\
\hline $\mathrm{C}$ & -2.30265 & 0.99212 & -4.28257 \\
\hline $\mathrm{C}$ & -4.19402 & -0.66888 & -4.39401 \\
\hline $\mathrm{C}$ & 6.87332 & -2.19855 & -1.76783 \\
\hline $\mathrm{C}$ & 6.96028 & -1.97486 & -3.28503 \\
\hline $\mathrm{C}$ & 7.74393 & -3.40243 & -1.35189 \\
\hline $\mathrm{C}$ & 2.19822 & -4.03982 & -2.35071 \\
\hline $\mathrm{C}$ & 2.74013 & -5.41479 & -2.78623 \\
\hline $\mathrm{C}$ & 1.79549 & -3.18377 & -3.56580 \\
\hline $\mathrm{C}$ & 3.66150 & -1.82511 & 2.08737 \\
\hline $\mathrm{C}$ & 3.81066 & -0.30146 & 2.21247 \\
\hline $\mathrm{C}$ & 4.57416 & -2.55934 & 3.08569 \\
\hline $\mathrm{H}$ & 0.93813 & 4.12017 & 3.45434 \\
\hline $\mathrm{H}$ & -0.48470 & 3.14265 & 4.53446 \\
\hline
\end{tabular}




\begin{tabular}{|c|c|c|c|}
\hline $\mathrm{H}$ & 0.05191 & 1.80187 & 5.56971 \\
\hline $\mathrm{H}$ & -2.40307 & 1.84583 & 5.56308 \\
\hline $\mathrm{H}$ & -2.43854 & 1.90702 & 3.78508 \\
\hline $\mathrm{H}$ & -1.34042 & -1.52854 & 3.58445 \\
\hline $\mathrm{H}$ & -1.77613 & -0.12676 & 2.58316 \\
\hline $\mathrm{H}$ & 0.65482 & -0.35590 & 2.54508 \\
\hline $\mathrm{H}$ & 0.72006 & -0.41619 & 4.34002 \\
\hline $\mathrm{H}$ & 1.65376 & 4.70133 & 0.87785 \\
\hline $\mathrm{H}$ & 0.89108 & 6.17917 & 0.20414 \\
\hline $\mathrm{H}$ & -0.41209 & 1.91305 & -1.57743 \\
\hline $\mathrm{H}$ & 0.97049 & 3.42446 & -4.04481 \\
\hline $\mathrm{H}$ & 2.37427 & 2.84570 & -3.17716 \\
\hline $\mathrm{H}$ & 0.89334 & 1.84318 & -3.21042 \\
\hline $\mathrm{H}$ & -1.58665 & 1.91448 & 1.27897 \\
\hline $\mathrm{H}$ & -2.85810 & 2.91345 & 0.54566 \\
\hline $\mathrm{H}$ & -2.12489 & 1.62014 & -0.37117 \\
\hline $\mathrm{H}$ & 2.49973 & 7.25505 & -0.78908 \\
\hline $\mathrm{H}$ & 3.66614 & 5.98495 & -0.39349 \\
\hline $\mathrm{H}$ & 3.88917 & 6.96161 & -1.87070 \\
\hline $\mathrm{H}$ & -3.15411 & 4.80463 & 1.50161 \\
\hline $\mathrm{H}$ & -2.56982 & 5.48077 & 3.04597 \\
\hline $\mathrm{H}$ & -2.31282 & 3.76330 & 2.65003 \\
\hline $\mathrm{H}$ & -2.91841 & -4.36048 & 2.08394 \\
\hline $\mathrm{H}$ & 1.51529 & -5.88331 & 3.74893 \\
\hline $\mathrm{H}$ & -0.55739 & -6.56766 & 4.92036 \\
\hline $\mathrm{H}$ & -2.77238 & -5.77465 & 4.09080 \\
\hline $\mathrm{H}$ & 2.62912 & -4.67385 & 1.92524 \\
\hline $\mathrm{H}$ & -5.49566 & -2.19551 & -1.78579 \\
\hline $\mathrm{H}$ & -1.62465 & -5.85343 & -0.19480 \\
\hline $\mathrm{H}$ & -3.13067 & -7.57196 & -1.08054 \\
\hline $\mathrm{H}$ & -5.33981 & -6.94389 & -2.05605 \\
\hline $\mathrm{H}$ & -5.99272 & -4.55652 & -2.18382 \\
\hline $\mathrm{H}$ & 5.90434 & -1.50194 & 0.65647 \\
\hline $\mathrm{H}$ & 4.66217 & -3.29672 & -3.01725 \\
\hline $\mathrm{H}$ & -4.13608 & 2.55124 & -3.30119 \\
\hline $\mathrm{H}$ & -5.74297 & 2.41046 & 0.65479 \\
\hline $\mathrm{H}$ & -4.21897 & -0.90067 & 1.39467 \\
\hline $\mathrm{H}$ & -6.44264 & -1.55497 & 0.53066 \\
\hline $\mathrm{H}$ & -6.50350 & -1.35677 & 2.29341 \\
\hline $\mathrm{H}$ & -7.16720 & -0.09588 & 1.23271 \\
\hline $\mathrm{H}$ & -3.92828 & 1.41620 & 2.43426 \\
\hline $\mathrm{H}$ & -5.68069 & 1.45740 & 2.67680 \\
\hline $\mathrm{H}$ & -4.70856 & 0.19761 & 3.45357 \\
\hline $\mathrm{H}$ & -5.91484 & 4.37467 & -0.51753 \\
\hline $\mathrm{H}$ & -7.35431 & 3.63563 & -2.41795 \\
\hline $\mathrm{H}$ & -6.82179 & 5.31785 & -2.63077 \\
\hline
\end{tabular}




\begin{tabular}{|c|c|c|c|}
\hline $\mathrm{H}$ & -6.05871 & 4.01792 & -3.56200 \\
\hline $\mathrm{H}$ & -3.48924 & 4.91518 & -0.88548 \\
\hline $\mathrm{H}$ & -3.72979 & 4.80755 & -2.63098 \\
\hline $\mathrm{H}$ & -4.55349 & 6.07466 & -1.70745 \\
\hline $\mathrm{H}$ & -2.49806 & -0.74238 & -3.06666 \\
\hline $\mathrm{H}$ & -1.64309 & 1.57005 & -3.63267 \\
\hline $\mathrm{H}$ & -1.67419 & 0.42768 & -4.97961 \\
\hline $\mathrm{H}$ & -2.90939 & 1.68658 & -4.87711 \\
\hline $\mathrm{H}$ & -4.76066 & -1.44212 & -3.86775 \\
\hline $\mathrm{H}$ & -4.90802 & 0.06303 & -4.79212 \\
\hline $\mathrm{H}$ & -3.68415 & -1.14216 & -5.24180 \\
\hline $\mathrm{H}$ & 7.28884 & -1.30894 & -1.27507 \\
\hline $\mathrm{H}$ & 6.30197 & -1.16465 & -3.61603 \\
\hline $\mathrm{H}$ & 6.68284 & -2.87863 & -3.83998 \\
\hline $\mathrm{H}$ & 7.98686 & -1.72043 & -3.57195 \\
\hline $\mathrm{H}$ & 7.36313 & -4.32453 & -1.80742 \\
\hline $\mathrm{H}$ & 8.78347 & -3.26542 & -1.67455 \\
\hline $\mathrm{H}$ & 7.73448 & -3.53831 & -0.26500 \\
\hline $\mathrm{H}$ & 1.28881 & -4.23223 & -1.77761 \\
\hline $\mathrm{H}$ & 3.00251 & -6.02822 & -1.91667 \\
\hline $\mathrm{H}$ & 1.98479 & -5.95363 & -3.37082 \\
\hline $\mathrm{H}$ & 3.63641 & -5.31828 & -3.41014 \\
\hline $\mathrm{H}$ & 1.36968 & -2.22995 & -3.24333 \\
\hline $\mathrm{H}$ & 2.65751 & -2.98140 & -4.21341 \\
\hline $\mathrm{H}$ & 1.04357 & -3.70931 & -4.16694 \\
\hline $\mathrm{H}$ & 2.62717 & -2.06052 & 2.35139 \\
\hline $\mathrm{H}$ & 3.15697 & 0.18787 & 1.49086 \\
\hline $\mathrm{H}$ & 3.53911 & 0.03168 & 3.22242 \\
\hline $\mathrm{H}$ & 4.83474 & 0.03482 & 2.01468 \\
\hline $\mathrm{H}$ & 4.44038 & -3.64560 & 3.03108 \\
\hline $\mathrm{H}$ & 5.63117 & -2.34638 & 2.88673 \\
\hline $\mathrm{H}$ & 4.35640 & -2.24033 & 4.11239 \\
\hline $\mathrm{C}$ & 5.14028 & 2.05195 & -0.74218 \\
\hline $\mathrm{C}$ & 5.60669 & 3.02227 & 0.15565 \\
\hline $\mathrm{C}$ & 4.73933 & 3.68680 & 1.01975 \\
\hline $\mathrm{C}$ & 3.36337 & 3.39561 & 1.02916 \\
\hline $\mathrm{C}$ & 2.90275 & 2.42047 & 0.12733 \\
\hline $\mathrm{C}$ & 3.77416 & 1.75444 & -0.72873 \\
\hline $\mathrm{C}$ & 6.06797 & 1.36230 & -1.70888 \\
\hline $\mathrm{H}$ & 6.66761 & 3.26142 & 0.17992 \\
\hline $\mathrm{H}$ & 5.14614 & 4.42334 & 1.70516 \\
\hline $\mathrm{H}$ & 1.85913 & 2.14016 & 0.10248 \\
\hline $\mathrm{H}$ & 3.37851 & 0.98022 & -1.38083 \\
\hline $\mathrm{H}$ & 5.68199 & 0.37585 & -1.97728 \\
\hline $\mathrm{H}$ & 6.17404 & 1.94257 & -2.63517 \\
\hline $\mathrm{H}$ & 7.07146 & 1.23517 & -1.28784 \\
\hline
\end{tabular}




$\begin{array}{llll}\mathrm{C} & 2.92201 & 5.44842 & 2.52706 \\ \mathrm{H} & 3.59882 & 5.22913 & 3.36249 \\ \mathrm{H} & 3.46303 & 6.06429 & 1.80418 \\ \mathrm{H} & 2.07986 & 6.03210 & 2.90606\end{array}$

\section{TS6-E}

B3LYP-D3/6-31G(d) Energy = -3928.749014

B3LYP-D3/6-31G(d) Free Energy $=-3927.355909$

Number of Imaginary Frequencies $=1(-1009.15)$

$\begin{array}{lccc}\text { B3LYP-D3/6-31G(d) Geometry } & \\ \mathrm{C} & 3.30678 & 0.74750 & 1.74384 \\ \mathrm{C} & 4.46227 & 0.62145 & 0.87870 \\ \mathrm{C} & 3.36827 & 1.21964 & 3.03086 \\ \mathrm{C} & 4.33461 & -0.29240 & -0.30689 \\ \mathrm{C} & 5.84918 & 0.77189 & 1.50055 \\ \mathrm{C} & 3.13050 & -0.96183 & -0.60196 \\ \mathrm{C} & 2.98140 & -1.70572 & -1.76506 \\ \mathrm{C} & 4.02671 & -1.83437 & -2.68951 \\ \mathrm{C} & 5.22943 & -1.17860 & -2.40109 \\ \mathrm{C} & 5.38040 & -0.41918 & -1.23965 \\ \mathrm{C} & 3.85323 & -2.67113 & -3.93220 \\ \mathrm{~N} & 2.35492 & 1.35658 & 3.91712 \\ \mathrm{C} & 2.57003 & 2.02118 & 5.20268 \\ \mathrm{C} & 1.83412 & 1.26301 & 6.30969 \\ \mathrm{O} & 0.45400 & 1.14295 & 6.00684 \\ \mathrm{C} & 0.26373 & 0.41731 & 4.79524 \\ \mathrm{C} & 0.94119 & 1.10981 & 3.61419 \\ \mathrm{H} & 4.32479 & 1.52498 & 3.44296 \\ \mathrm{C} & 4.14903 & 2.92573 & -0.47264 \\ \mathrm{C} & 2.98095 & 3.38884 & 0.27025 \\ \mathrm{C} & 1.74188 & 2.96970 & -0.18052 \\ \mathrm{~N} & 1.68187 & 2.26122 & -1.34836 \\ \mathrm{C} & 2.71849 & 2.03720 & -2.21192 \\ \mathrm{C} & 3.97613 & 2.47876 & -1.84779 \\ \mathrm{C} & 2.31112 & 1.29778 & -3.45856 \\ \mathrm{C} & 0.40121 & 3.11793 & 0.47824 \\ \mathrm{C} & 5.22299 & 2.40123 & -2.65267 \\ \mathrm{C} & 3.29430 & 4.06269 & 1.55545 \\ \mathrm{C} & 5.19569 & 2.15561 & -4.15094 \\ \mathrm{O} & 6.30439 & 2.56203 & -2.09332 \\ \mathrm{C} & 2.22883 & 4.72752 & 2.41128 \\ \mathrm{O} & 4.46101 & 4.08512 & 1.94451 \\ \mathrm{C} & -5.73194 & -2.35292 & -1.35083 \\ \mathrm{C} & -5.12021 & -1.10131 & -1.06358 \\ \mathrm{C} & -5.75660 & 0.08674 & -1.55006\end{array}$




\begin{tabular}{|c|c|c|c|}
\hline $\mathrm{C}$ & -6.99179 & -0.01707 & -2.24451 \\
\hline $\mathrm{C}$ & -7.56863 & -1.24289 & -2.48357 \\
\hline $\mathrm{C}$ & -6.92155 & -2.42120 & -2.04158 \\
\hline $\mathrm{C}$ & -3.88641 & -0.98067 & -0.33644 \\
\hline $\mathrm{C}$ & -3.28453 & 0.26661 & -0.26201 \\
\hline $\mathrm{C}$ & -3.89029 & 1.45392 & -0.76017 \\
\hline $\mathrm{C}$ & -5.12905 & 1.34291 & -1.35403 \\
\hline $\mathrm{C}$ & -3.23382 & -2.15652 & 0.30514 \\
\hline $\mathrm{C}$ & -3.92957 & -2.97797 & 1.25696 \\
\hline $\mathrm{C}$ & -3.30061 & -4.17428 & 1.73111 \\
\hline $\mathrm{C}$ & -1.99549 & -4.49636 & 1.28294 \\
\hline $\mathrm{C}$ & -1.27581 & -3.65634 & 0.45924 \\
\hline $\mathrm{C}$ & -1.91564 & -2.47067 & 0.00096 \\
\hline $\mathrm{C}$ & -5.21009 & -2.64365 & 1.77867 \\
\hline $\mathrm{C}$ & -5.84434 & -3.46298 & 2.68607 \\
\hline $\mathrm{C}$ & -5.23650 & -4.66438 & 3.12209 \\
\hline $\mathrm{C}$ & -3.98877 & -5.00654 & 2.65461 \\
\hline $\mathrm{C}$ & -3.21334 & 2.78309 & -0.63599 \\
\hline $\mathrm{O}$ & -1.20213 & -1.65576 & -0.85648 \\
\hline $\mathrm{O}$ & -2.07491 & 0.39168 & 0.39059 \\
\hline $\mathrm{C}$ & 0.11747 & -4.01786 & 0.04907 \\
\hline $\mathrm{C}$ & -3.13517 & 3.42747 & 0.61755 \\
\hline $\mathrm{C}$ & -2.55505 & 4.69997 & 0.68963 \\
\hline $\mathrm{C}$ & -2.04580 & 5.34992 & -0.43460 \\
\hline $\mathrm{C}$ & -2.12326 & 4.68710 & -1.66210 \\
\hline $\mathrm{C}$ & -2.68364 & 3.41194 & -1.78863 \\
\hline $\mathrm{C}$ & 1.15235 & -4.03532 & 1.01303 \\
\hline $\mathrm{C}$ & 2.41356 & -4.51144 & 0.64279 \\
\hline $\mathrm{C}$ & 2.69586 & -4.94804 & -0.65196 \\
\hline $\mathrm{C}$ & 1.66880 & -4.88832 & -1.59468 \\
\hline $\mathrm{C}$ & 0.38559 & -4.42843 & -1.27618 \\
\hline $\mathrm{P}$ & -0.69388 & -0.16804 & -0.34084 \\
\hline $\mathrm{O}$ & 0.31812 & -0.24942 & 0.76331 \\
\hline $\mathrm{O}$ & -0.41765 & 0.59958 & -1.61203 \\
\hline $\mathrm{C}$ & -0.67537 & -4.40084 & -2.37307 \\
\hline $\mathrm{C}$ & -0.92903 & -5.80462 & -2.95272 \\
\hline $\mathrm{C}$ & -0.30789 & -3.39400 & -3.47960 \\
\hline $\mathrm{C}$ & 4.06236 & -5.50639 & -1.01991 \\
\hline $\mathrm{C}$ & 4.21223 & -6.94716 & -0.49365 \\
\hline $\mathrm{C}$ & 5.22527 & -4.62396 & -0.53374 \\
\hline $\mathrm{C}$ & 0.94649 & -3.55988 & 2.45007 \\
\hline $\mathrm{C}$ & 1.98798 & -2.50368 & 2.85607 \\
\hline $\mathrm{C}$ & 0.95684 & -4.74408 & 3.43473 \\
\hline $\mathrm{C}$ & -1.42071 & 6.73308 & -0.32551 \\
\hline $\mathrm{C}$ & -2.28807 & 7.79087 & -1.03318 \\
\hline $\mathrm{C}$ & 0.02218 & 6.76485 & -0.86375 \\
\hline
\end{tabular}




\begin{tabular}{|c|c|c|c|}
\hline $\mathrm{C}$ & -2.71670 & 2.75047 & -3.16508 \\
\hline $\mathrm{C}$ & -1.35866 & 2.81008 & -3.88587 \\
\hline $\mathrm{C}$ & -3.81859 & 3.37297 & -4.04383 \\
\hline $\mathrm{C}$ & -3.66233 & 2.78483 & 1.89770 \\
\hline $\mathrm{C}$ & -4.74612 & 3.65138 & 2.56466 \\
\hline $\mathrm{C}$ & -2.51624 & 2.46687 & 2.87738 \\
\hline $\mathrm{H}$ & 2.33756 & 0.50558 & 1.32987 \\
\hline $\mathrm{H}$ & 6.62445 & 0.86021 & 0.73881 \\
\hline $\mathrm{H}$ & 6.07868 & -0.09893 & 2.12654 \\
\hline $\mathrm{H}$ & 5.90503 & 1.67811 & 2.10809 \\
\hline $\mathrm{H}$ & 2.27659 & -0.90314 & 0.05754 \\
\hline $\mathrm{H}$ & 2.03376 & -2.20157 & -1.94592 \\
\hline $\mathrm{H}$ & 6.06325 & -1.25272 & -3.09594 \\
\hline $\mathrm{H}$ & 6.31237 & 0.11403 & -1.09590 \\
\hline $\mathrm{H}$ & 4.65033 & -2.48984 & -4.66078 \\
\hline $\mathrm{H}$ & 3.86467 & -3.73989 & -3.68315 \\
\hline $\mathrm{H}$ & 2.89023 & -2.46930 & -4.41509 \\
\hline $\mathrm{H}$ & 2.18160 & 3.04927 & 5.15421 \\
\hline $\mathrm{H}$ & 3.64249 & 2.06921 & 5.41345 \\
\hline $\mathrm{H}$ & 2.29040 & 0.26684 & 6.43879 \\
\hline $\mathrm{H}$ & 1.90583 & 1.80865 & 7.25546 \\
\hline $\mathrm{H}$ & 0.65246 & -0.60676 & 4.90295 \\
\hline $\mathrm{H}$ & -0.81431 & 0.36813 & 4.62169 \\
\hline $\mathrm{H}$ & 0.44296 & 2.07578 & 3.45041 \\
\hline $\mathrm{H}$ & 0.82684 & 0.50899 & 2.71123 \\
\hline $\mathrm{H}$ & 4.43649 & 1.81059 & 0.18041 \\
\hline $\mathrm{H}$ & 5.08068 & 3.44464 & -0.26065 \\
\hline $\mathrm{H}$ & 0.79924 & 1.72507 & -1.51746 \\
\hline $\mathrm{H}$ & 3.08094 & 0.59253 & -3.76703 \\
\hline $\mathrm{H}$ & 1.39294 & 0.73686 & -3.26598 \\
\hline $\mathrm{H}$ & 2.11649 & 1.99315 & -4.28390 \\
\hline $\mathrm{H}$ & 0.28473 & 2.34689 & 1.24262 \\
\hline $\mathrm{H}$ & 0.25786 & 4.09211 & 0.93503 \\
\hline $\mathrm{H}$ & -0.39901 & 2.97347 & -0.24671 \\
\hline $\mathrm{H}$ & 6.14336 & 2.50711 & -4.56433 \\
\hline $\mathrm{H}$ & 5.11615 & 1.07942 & -4.34491 \\
\hline $\mathrm{H}$ & 4.36120 & 2.65330 & -4.65189 \\
\hline $\mathrm{H}$ & 1.53449 & 3.98700 & 2.81927 \\
\hline $\mathrm{H}$ & 1.64224 & 5.45622 & 1.84153 \\
\hline $\mathrm{H}$ & 2.73468 & 5.23414 & 3.23558 \\
\hline $\mathrm{H}$ & -5.24498 & -3.26489 & -1.02582 \\
\hline $\mathrm{H}$ & -7.46581 & 0.89583 & -2.59782 \\
\hline $\mathrm{H}$ & -8.51012 & -1.31059 & -3.02176 \\
\hline $\mathrm{H}$ & -7.36468 & -3.39048 & -2.25374 \\
\hline $\mathrm{H}$ & -5.62954 & 2.23958 & -1.70877 \\
\hline $\mathrm{H}$ & -1.53950 & -5.42335 & 1.61939 \\
\hline
\end{tabular}




\begin{tabular}{|c|c|c|c|}
\hline $\mathrm{H}$ & -5.68531 & -1.72310 & 1.46023 \\
\hline $\mathrm{H}$ & -6.81921 & -3.18112 & 3.07479 \\
\hline $\mathrm{H}$ & -5.75067 & -5.30504 & 3.83331 \\
\hline $\mathrm{H}$ & -3.50007 & -5.91625 & 2.99593 \\
\hline $\mathrm{H}$ & -2.49300 & 5.19807 & 1.65504 \\
\hline $\mathrm{H}$ & -1.72966 & 5.17469 & -2.54942 \\
\hline $\mathrm{H}$ & 3.20019 & -4.53831 & 1.39072 \\
\hline $\mathrm{H}$ & 1.87508 & -5.21150 & -2.61287 \\
\hline $\mathrm{H}$ & -1.61814 & -4.06431 & -1.93417 \\
\hline $\mathrm{H}$ & -1.21336 & -6.51018 & -2.16390 \\
\hline $\mathrm{H}$ & -1.73824 & -5.77234 & -3.69212 \\
\hline $\mathrm{H}$ & -0.03812 & -6.20292 & -3.45244 \\
\hline $\mathrm{H}$ & -1.09337 & -3.36331 & -4.24443 \\
\hline $\mathrm{H}$ & 0.62959 & -3.67520 & -3.97598 \\
\hline $\mathrm{H}$ & -0.19877 & -2.38775 & -3.06487 \\
\hline $\mathrm{H}$ & 4.11381 & -5.54888 & -2.11731 \\
\hline $\mathrm{H}$ & 3.41414 & -7.59295 & -0.87616 \\
\hline $\mathrm{H}$ & 5.17716 & -7.37566 & -0.79134 \\
\hline $\mathrm{H}$ & 4.15785 & -6.96211 & 0.60176 \\
\hline $\mathrm{H}$ & 5.11306 & -3.59056 & -0.87266 \\
\hline $\mathrm{H}$ & 5.28651 & -4.61400 & 0.56082 \\
\hline $\mathrm{H}$ & 6.17958 & -5.01168 & -0.90982 \\
\hline $\mathrm{H}$ & -0.03327 & -3.07771 & 2.51264 \\
\hline $\mathrm{H}$ & 1.92486 & -1.63746 & 2.19707 \\
\hline $\mathrm{H}$ & 1.80827 & -2.17134 & 3.88559 \\
\hline $\mathrm{H}$ & 3.01184 & -2.89208 & 2.81573 \\
\hline $\mathrm{H}$ & 1.92494 & -5.25936 & 3.41734 \\
\hline $\mathrm{H}$ & 0.18506 & -5.48037 & 3.18664 \\
\hline $\mathrm{H}$ & 0.77797 & -4.39692 & 4.45981 \\
\hline $\mathrm{H}$ & -1.38301 & 6.99343 & 0.74168 \\
\hline $\mathrm{H}$ & -3.30529 & 7.80042 & -0.62710 \\
\hline $\mathrm{H}$ & -2.35913 & 7.57957 & -2.10687 \\
\hline $\mathrm{H}$ & -1.85880 & 8.79307 & -0.91435 \\
\hline $\mathrm{H}$ & 0.04985 & 6.54851 & -1.93790 \\
\hline $\mathrm{H}$ & 0.46913 & 7.75459 & -0.71334 \\
\hline $\mathrm{H}$ & 0.65721 & 6.02405 & -0.36532 \\
\hline $\mathrm{H}$ & -2.94952 & 1.69180 & -3.02374 \\
\hline $\mathrm{H}$ & -0.58146 & 2.36351 & -3.26489 \\
\hline $\mathrm{H}$ & -1.41150 & 2.24449 & -4.82371 \\
\hline $\mathrm{H}$ & -1.06822 & 3.83691 & -4.13876 \\
\hline $\mathrm{H}$ & -4.80551 & 3.28182 & -3.57895 \\
\hline $\mathrm{H}$ & -3.62613 & 4.44028 & -4.20987 \\
\hline $\mathrm{H}$ & -3.85741 & 2.87950 & -5.02242 \\
\hline $\mathrm{H}$ & -4.13197 & 1.83298 & 1.63423 \\
\hline $\mathrm{H}$ & -5.56815 & 3.85633 & 1.86980 \\
\hline $\mathrm{H}$ & -5.15819 & 3.13904 & 3.44213 \\
\hline
\end{tabular}




$\begin{array}{llll}\mathrm{H} & -4.34438 & 4.61440 & 2.90113 \\ \mathrm{H} & -1.80456 & 1.77923 & 2.41346 \\ \mathrm{H} & -1.98373 & 3.37820 & 3.17774 \\ \mathrm{H} & -2.90865 & 1.99650 & 3.78744\end{array}$

\section{TS6-Z}

B3LYP-D3/6-31G(d) Energy $=-3928.744026$

B3LYP-D3/6-31G(d) Free Energy $=-3927.350142$

Number of Imaginary Frequencies $=1(-1078.87)$

$\begin{array}{lccc}\text { B3LYP-D3/6-31G(d) Geometry } & \\ \mathrm{C} & 3.40196 & 0.72784 & 1.11777 \\ \mathrm{C} & 4.45010 & -0.09381 & 0.57944 \\ \mathrm{C} & 3.59535 & 2.05431 & 1.44136 \\ \mathrm{C} & 5.89566 & 0.14284 & 0.93374 \\ \mathrm{C} & 4.10716 & -1.56400 & 0.39942 \\ \mathrm{C} & 6.91205 & -0.21180 & 0.02773 \\ \mathrm{C} & 8.25265 & -0.04563 & 0.36100 \\ \mathrm{C} & 8.63738 & 0.46484 & 1.60973 \\ \mathrm{C} & 7.62612 & 0.78713 & 2.52062 \\ \mathrm{C} & 6.27924 & 0.62899 & 2.19275 \\ \mathrm{C} & 10.09448 & 0.67075 & 1.94729 \\ \mathrm{~N} & 2.69931 & 2.93840 & 1.91226 \\ \mathrm{C} & 3.16818 & 4.24114 & 2.39738 \\ \mathrm{C} & 2.10646 & 5.30487 & 2.14480 \\ \mathrm{O} & 0.87132 & 4.93494 & 2.74093 \\ \mathrm{C} & 0.37678 & 3.72014 & 2.17877 \\ \mathrm{C} & 1.35192 & 2.55728 & 2.36285 \\ \mathrm{H} & 4.58900 & 2.47609 & 1.31981 \\ \mathrm{C} & 4.22171 & 0.70266 & -1.99052 \\ \mathrm{C} & 3.55196 & 1.97569 & -1.76181 \\ \mathrm{C} & 2.16187 & 1.97784 & -1.75348 \\ \mathrm{~N} & 1.50184 & 0.84707 & -2.11230 \\ \mathrm{C} & 2.07666 & -0.31534 & -2.55686 \\ \mathrm{C} & 3.45374 & -0.39650 & -2.59064 \\ \mathrm{C} & 1.07189 & -1.37380 & -2.92677 \\ \mathrm{C} & 1.28303 & 3.13590 & -1.39083 \\ \mathrm{C} & 4.26029 & -1.56340 & -3.01704 \\ \mathrm{C} & 4.33137 & 3.18578 & -1.40555 \\ \mathrm{C} & 3.65990 & -2.74693 & -3.75262 \\ \mathrm{O} & 5.46644 & -1.57743 & -2.76103 \\ \mathrm{C} & 5.84934 & 3.09877 & -1.47168 \\ \mathrm{O} & 3.80153 & 4.23793 & -1.05048 \\ \mathrm{C} & -6.23884 & -2.27399 & -0.63847 \\ \mathrm{C} & -5.58902 & -1.01673 & -0.49427 \\ \mathrm{C} & -6.21970 & 0.13529 & -1.06574\end{array}$




\begin{tabular}{|c|c|c|c|}
\hline $\mathrm{C}$ & -7.48719 & -0.00056 & -1.69304 \\
\hline $\mathrm{C}$ & -8.10138 & -1.22775 & -1.78966 \\
\hline $\mathrm{C}$ & -7.45983 & -2.37586 & -1.26789 \\
\hline $\mathrm{C}$ & -4.32170 & -0.85684 & 0.16553 \\
\hline $\mathrm{C}$ & -3.69458 & 0.37749 & 0.10768 \\
\hline $\mathrm{C}$ & -4.28767 & 1.52208 & -0.49557 \\
\hline $\mathrm{C}$ & -5.55246 & 1.38537 & -1.02453 \\
\hline $\mathrm{C}$ & -3.64487 & -1.99541 & 0.84312 \\
\hline $\mathrm{C}$ & -4.28835 & -2.75396 & 1.87891 \\
\hline $\mathrm{C}$ & -3.65734 & -3.94430 & 2.36497 \\
\hline $\mathrm{C}$ & -2.40046 & -4.32634 & 1.83320 \\
\hline $\mathrm{C}$ & -1.72809 & -3.54296 & 0.91981 \\
\hline $\mathrm{C}$ & -2.35704 & -2.35094 & 0.46267 \\
\hline $\mathrm{C}$ & -5.52199 & -2.36108 & 2.46807 \\
\hline $\mathrm{C}$ & -6.11055 & -3.11850 & 3.45631 \\
\hline $\mathrm{C}$ & -5.50137 & -4.31313 & 3.90924 \\
\hline $\mathrm{C}$ & -4.29814 & -4.71180 & 3.37436 \\
\hline $\mathrm{C}$ & -3.57360 & 2.83584 & -0.52166 \\
\hline $\mathrm{O}$ & -1.68118 & -1.59731 & -0.47406 \\
\hline $\mathrm{O}$ & -2.45426 & 0.52413 & 0.70999 \\
\hline $\mathrm{C}$ & -0.39595 & -3.95994 & 0.38439 \\
\hline $\mathrm{C}$ & -3.51007 & 3.61188 & 0.65523 \\
\hline $\mathrm{C}$ & -2.86468 & 4.85247 & 0.61689 \\
\hline $\mathrm{C}$ & -2.31937 & 5.36240 & -0.56458 \\
\hline $\mathrm{C}$ & -2.39642 & 4.57403 & -1.71498 \\
\hline $\mathrm{C}$ & -3.00134 & 3.31256 & -1.72301 \\
\hline $\mathrm{C}$ & 0.75072 & -3.90000 & 1.20753 \\
\hline $\mathrm{C}$ & 1.96668 & -4.38434 & 0.70824 \\
\hline $\mathrm{C}$ & 2.08273 & -4.91700 & -0.58030 \\
\hline $\mathrm{C}$ & 0.93935 & -4.92697 & -1.38536 \\
\hline $\mathrm{C}$ & -0.30371 & -4.47548 & -0.92628 \\
\hline$P$ & -1.14359 & -0.05903 & -0.11553 \\
\hline $\mathrm{O}$ & 0.03030 & -0.06538 & 0.81324 \\
\hline $\mathrm{O}$ & -1.05728 & 0.61650 & -1.46856 \\
\hline $\mathrm{C}$ & -1.53090 & -4.64003 & -1.82082 \\
\hline $\mathrm{C}$ & -1.75959 & -6.12112 & -2.17831 \\
\hline $\mathrm{C}$ & -1.45697 & -3.76396 & -3.08249 \\
\hline $\mathrm{C}$ & 3.34582 & -5.62760 & -1.05455 \\
\hline $\mathrm{C}$ & 3.41965 & -7.02181 & -0.39734 \\
\hline $\mathrm{C}$ & 4.65118 & -4.85408 & -0.81772 \\
\hline $\mathrm{C}$ & 0.67447 & -3.39190 & 2.64634 \\
\hline $\mathrm{C}$ & 1.65052 & -2.24044 & 2.92957 \\
\hline $\mathrm{C}$ & 0.87560 & -4.54927 & 3.64267 \\
\hline $\mathrm{C}$ & -1.65922 & 6.73295 & -0.62016 \\
\hline $\mathrm{C}$ & -0.24845 & 6.69015 & -0.00848 \\
\hline $\mathrm{C}$ & -2.51085 & 7.82944 & 0.04206 \\
\hline
\end{tabular}




\begin{tabular}{|c|c|c|c|}
\hline $\mathrm{C}$ & -3.09212 & 2.52873 & -3.03127 \\
\hline $\mathrm{C}$ & -1.79877 & 2.56263 & -3.86274 \\
\hline $\mathrm{C}$ & -4.26810 & 3.04308 & -3.88636 \\
\hline $\mathrm{C}$ & -4.18770 & 3.15939 & 1.94699 \\
\hline $\mathrm{C}$ & -5.27913 & 4.15638 & 2.37937 \\
\hline $\mathrm{C}$ & -3.18075 & 2.90879 & 3.08114 \\
\hline $\mathrm{H}$ & 2.39906 & 0.31177 & 1.12536 \\
\hline $\mathrm{H}$ & 4.17937 & -2.06962 & 1.36754 \\
\hline $\mathrm{H}$ & 4.80915 & -2.04600 & -0.27920 \\
\hline $\mathrm{H}$ & 3.08803 & -1.70400 & 0.02874 \\
\hline $\mathrm{H}$ & 6.64675 & -0.62131 & -0.94327 \\
\hline $\mathrm{H}$ & 9.01728 & -0.32138 & -0.36192 \\
\hline $\mathrm{H}$ & 7.89255 & 1.16065 & 3.50686 \\
\hline $\mathrm{H}$ & 5.51749 & 0.85912 & 2.93092 \\
\hline $\mathrm{H}$ & 10.71556 & -0.13992 & 1.55028 \\
\hline $\mathrm{H}$ & 10.47089 & 1.60743 & 1.51490 \\
\hline $\mathrm{H}$ & 10.25396 & 0.72214 & 3.02929 \\
\hline $\mathrm{H}$ & 4.09023 & 4.50235 & 1.87119 \\
\hline $\mathrm{H}$ & 3.37166 & 4.17600 & 3.47695 \\
\hline $\mathrm{H}$ & 2.40663 & 6.25300 & 2.60053 \\
\hline $\mathrm{H}$ & 1.99497 & 5.45441 & 1.06194 \\
\hline $\mathrm{H}$ & -0.55391 & 3.49356 & 2.69691 \\
\hline $\mathrm{H}$ & 0.14144 & 3.86527 & 1.11678 \\
\hline $\mathrm{H}$ & 0.98691 & 1.69101 & 1.80481 \\
\hline $\mathrm{H}$ & 1.40948 & 2.28702 & 3.42760 \\
\hline $\mathrm{H}$ & 4.45027 & 0.27932 & -0.76017 \\
\hline $\mathrm{H}$ & 5.25836 & 0.73604 & -2.31730 \\
\hline $\mathrm{H}$ & 0.46307 & 0.82014 & -1.93386 \\
\hline $\mathrm{H}$ & 1.16449 & -2.24877 & -2.27518 \\
\hline $\mathrm{H}$ & 0.06033 & -0.98624 & -2.80934 \\
\hline $\mathrm{H}$ & 1.19441 & -1.70867 & -3.95894 \\
\hline $\mathrm{H}$ & 1.60198 & 3.54699 & -0.43410 \\
\hline $\mathrm{H}$ & 1.39998 & 3.94719 & -2.11643 \\
\hline $\mathrm{H}$ & 0.23449 & 2.83487 & -1.34229 \\
\hline $\mathrm{H}$ & 4.47923 & -3.40671 & -4.04361 \\
\hline $\mathrm{H}$ & 2.96838 & -3.30148 & -3.10931 \\
\hline $\mathrm{H}$ & 3.10691 & -2.43478 & -4.64439 \\
\hline $\mathrm{H}$ & 6.18766 & 2.83133 & -2.48029 \\
\hline $\mathrm{H}$ & 6.23989 & 2.33475 & -0.79010 \\
\hline $\mathrm{H}$ & 6.26002 & 4.07298 & -1.20089 \\
\hline $\mathrm{H}$ & -5.75827 & -3.16500 & -0.25222 \\
\hline $\mathrm{H}$ & -7.95593 & 0.88739 & -2.11106 \\
\hline $\mathrm{H}$ & -9.06783 & -1.32091 & -2.27754 \\
\hline $\mathrm{H}$ & -7.93230 & -3.34930 & -1.36898 \\
\hline $\mathrm{H}$ & -6.04806 & 2.25639 & -1.44320 \\
\hline $\mathrm{H}$ & -1.94342 & -5.25146 & 2.17503 \\
\hline
\end{tabular}




\begin{tabular}{|c|c|c|c|}
\hline $\mathrm{H}$ & -5.99550 & -1.44450 & 2.13516 \\
\hline $\mathrm{H}$ & -7.04934 & -2.79282 & 3.89621 \\
\hline $\mathrm{H}$ & -5.97929 & -4.90449 & 4.68550 \\
\hline $\mathrm{H}$ & -3.80939 & -5.61781 & 3.72545 \\
\hline $\mathrm{H}$ & -2.81366 & 5.44508 & 1.52650 \\
\hline $\mathrm{H}$ & -1.97962 & 4.96633 & -2.63927 \\
\hline $\mathrm{H}$ & 2.83689 & -4.37564 & 1.35909 \\
\hline $\mathrm{H}$ & 1.00893 & -5.35386 & -2.38421 \\
\hline $\mathrm{H}$ & -2.40852 & -4.31254 & -1.25690 \\
\hline $\mathrm{H}$ & -1.82956 & -6.73745 & -1.27500 \\
\hline $\mathrm{H}$ & -2.69085 & -6.23665 & -2.74553 \\
\hline $\mathrm{H}$ & -0.94425 & -6.51994 & -2.79336 \\
\hline $\mathrm{H}$ & -1.43091 & -2.70711 & -2.80796 \\
\hline $\mathrm{H}$ & -0.56618 & -3.99577 & -3.67998 \\
\hline $\mathrm{H}$ & -2.33638 & -3.93118 & -3.71586 \\
\hline $\mathrm{H}$ & 3.24653 & -5.78062 & -2.13877 \\
\hline $\mathrm{H}$ & 2.50874 & -7.59773 & -0.59294 \\
\hline $\mathrm{H}$ & 4.27785 & -7.58945 & -0.77720 \\
\hline $\mathrm{H}$ & 3.52792 & -6.92736 & 0.68992 \\
\hline $\mathrm{H}$ & 4.67472 & -3.91308 & -1.37249 \\
\hline $\mathrm{H}$ & 4.79894 & -4.62458 & 0.24340 \\
\hline $\mathrm{H}$ & 5.50943 & -5.45201 & -1.14586 \\
\hline $\mathrm{H}$ & -0.32917 & -2.99074 & 2.80622 \\
\hline $\mathrm{H}$ & 1.46798 & -1.41554 & 2.23770 \\
\hline $\mathrm{H}$ & 1.50436 & -1.87064 & 3.95189 \\
\hline $\mathrm{H}$ & 2.69463 & -2.56202 & 2.84495 \\
\hline $\mathrm{H}$ & 0.14322 & -5.34816 & 3.48064 \\
\hline $\mathrm{H}$ & 1.87505 & -4.98982 & 3.54052 \\
\hline $\mathrm{H}$ & 0.76900 & -4.19256 & 4.67420 \\
\hline $\mathrm{H}$ & -1.55260 & 6.99667 & -1.68169 \\
\hline $\mathrm{H}$ & 0.37836 & 5.96115 & -0.53478 \\
\hline $\mathrm{H}$ & -0.28893 & 6.40164 & 1.04767 \\
\hline $\mathrm{H}$ & 0.24084 & 7.66988 & -0.07724 \\
\hline $\mathrm{H}$ & -2.60102 & 7.66896 & 1.12262 \\
\hline $\mathrm{H}$ & -2.05066 & 8.81361 & -0.10601 \\
\hline $\mathrm{H}$ & -3.52182 & 7.85448 & -0.37903 \\
\hline $\mathrm{H}$ & -3.27626 & 1.48135 & -2.77833 \\
\hline $\mathrm{H}$ & -0.95065 & 2.21332 & -3.27399 \\
\hline $\mathrm{H}$ & -1.90363 & 1.90259 & -4.73220 \\
\hline $\mathrm{H}$ & -1.57719 & 3.56671 & -4.24425 \\
\hline $\mathrm{H}$ & -5.22127 & 2.96944 & -3.35507 \\
\hline $\mathrm{H}$ & -4.11693 & 4.09609 & -4.15503 \\
\hline $\mathrm{H}$ & -4.35284 & 2.46497 & -4.81481 \\
\hline $\mathrm{H}$ & -4.68844 & 2.20734 & 1.75046 \\
\hline $\mathrm{H}$ & -6.01434 & 4.30465 & 1.58048 \\
\hline $\mathrm{H}$ & -5.80644 & 3.78681 & 3.26720 \\
\hline
\end{tabular}




$\begin{array}{llll}\mathrm{H} & -4.85365 & 5.13589 & 2.62760 \\ \mathrm{H} & -2.44364 & 2.15936 & 2.77670 \\ \mathrm{H} & -2.65828 & 3.83263 & 3.35905 \\ \mathrm{H} & -3.69560 & 2.53908 & 3.97627\end{array}$

\section{TS7-E}

B3LYP-D3/6-31G(d) Energy $=-3928.747970$

B3LYP-D3/6-31G(d) Free Energy $=-3927.353134$

Number of Imaginary Frequencies $=1(-1134.42)$

$\begin{array}{lrrr}\text { B3LYP-D } 3 / 6-31 G(d) \text { Geometry } & \\ \text { C } & -4.30037 & 0.46637 & -0.01674 \\ \text { C } & -4.44157 & -0.41139 & 1.11107 \\ \text { C } & -3.09215 & 0.85243 & -0.56630 \\ \text { C } & -5.81868 & -0.47057 & 1.72181 \\ \text { C } & -3.31039 & -0.55080 & 2.12541 \\ \text { C } & -6.63452 & 0.67118 & 1.76058 \\ \text { C } & -7.89287 & 0.63235 & 2.35972 \\ \text { C } & -8.38574 & -0.54458 & 2.93450 \\ \text { C } & -7.56507 & -1.68033 & 2.90164 \\ \text { C } & -6.30420 & -1.64880 & 2.31181 \\ \text { C } & -9.76428 & -0.59910 & 3.54848 \\ \text { N } & -2.92440 & 1.59177 & -1.67753 \\ \text { C } & -4.06230 & 2.16934 & -2.39911 \\ \text { C } & -3.70400 & 2.43738 & -3.86110 \\ \text { O } & -2.50474 & 3.18303 & -3.98711 \\ \text { C } & -1.40961 & 2.45596 & -3.43614 \\ \text { C } & -1.60231 & 2.18923 & -1.94836 \\ \text { H } & -2.15621 & 0.56084 & -0.09330 \\ \text { C } & -3.96672 & -2.73976 & -0.18409 \\ \text { C } & -2.80495 & -3.29444 & 0.51653 \\ \text { C } & -1.54697 & -2.91673 & 0.08837 \\ \text { N } & -1.43894 & -2.22132 & -1.08856 \\ \text { C } & -2.47065 & -1.88554 & -1.91084 \\ \text { C } & -3.76808 & -2.16689 & -1.50769 \\ \text { C } & -2.06323 & -1.23910 & -3.19994 \\ \text { C } & -0.23743 & -3.12449 & 0.78443 \\ \text { C } & -4.94256 & -1.72952 & -2.30511 \\ \text { C } & -3.12651 & -4.10465 & 1.71713 \\ \text { C } & -6.32428 & -2.02328 & -1.74089 \\ \text { O } & -4.83527 & -1.13399 & -3.37535 \\ \text { C } & -2.07178 & -4.81815 & 2.54453 \\ \text { O } & -4.30535 & -4.21609 & 2.05675 \\ \text { C } & 6.38710 & 1.45245 & 0.01565 \\ \text { C } & 5.57761 & 0.28235 & 0.01116 \\ \text { C } & 6.14111 & -0.92285 & -0.51756 \\ & & & \\ & & & \end{array}$




\begin{tabular}{|c|c|c|c|}
\hline $\mathrm{C}$ & 7.48971 & -0.92844 & -0.96412 \\
\hline $\mathrm{C}$ & 8.25212 & 0.21586 & -0.92407 \\
\hline $\mathrm{C}$ & 7.68627 & 1.41941 & -0.44033 \\
\hline $\mathrm{C}$ & 4.22161 & 0.26469 & 0.48688 \\
\hline $\mathrm{C}$ & 3.45490 & -0.87224 & 0.28119 \\
\hline $\mathrm{C}$ & 3.99933 & -2.07519 & -0.25445 \\
\hline $\mathrm{C}$ & 5.33273 & -2.08350 & -0.60305 \\
\hline $\mathrm{C}$ & 3.62744 & 1.45508 & 1.15218 \\
\hline $\mathrm{C}$ & 4.22707 & 2.04389 & 2.31652 \\
\hline $\mathrm{C}$ & 3.72046 & 3.29229 & 2.80104 \\
\hline $\mathrm{C}$ & 2.64391 & 3.91108 & 2.11866 \\
\hline $\mathrm{C}$ & 2.00257 & 3.30427 & 1.05875 \\
\hline $\mathrm{C}$ & 2.47914 & 2.03355 & 0.63147 \\
\hline $\mathrm{C}$ & 5.28980 & 1.42702 & 3.03234 \\
\hline $\mathrm{C}$ & 5.83438 & 2.02395 & 4.14770 \\
\hline $\mathrm{C}$ & 5.35102 & 3.27256 & 4.60669 \\
\hline $\mathrm{C}$ & 4.31382 & 3.88910 & 3.94564 \\
\hline $\mathrm{C}$ & 3.17941 & -3.32188 & -0.37785 \\
\hline $\mathrm{O}$ & 1.82081 & 1.41439 & -0.41680 \\
\hline $\mathrm{O}$ & 2.13636 & -0.87732 & 0.69644 \\
\hline $\mathrm{C}$ & 0.91413 & 4.02923 & 0.33394 \\
\hline $\mathrm{C}$ & 3.04910 & -4.17917 & 0.73388 \\
\hline $\mathrm{C}$ & 2.28961 & -5.34889 & 0.59965 \\
\hline $\mathrm{C}$ & 1.65645 & -5.68609 & -0.59586 \\
\hline $\mathrm{C}$ & 1.81626 & -4.82837 & -1.68897 \\
\hline $\mathrm{C}$ & 2.56275 & -3.64958 & -1.60889 \\
\hline $\mathrm{C}$ & -0.31469 & 4.30215 & 0.97580 \\
\hline $\mathrm{C}$ & -1.24586 & 5.12465 & 0.33114 \\
\hline $\mathrm{C}$ & -1.00257 & 5.68314 & -0.92712 \\
\hline $\mathrm{C}$ & 0.19899 & 5.35880 & -1.56013 \\
\hline $\mathrm{C}$ & 1.16704 & 4.54693 & -0.95731 \\
\hline $\mathrm{P}$ & 0.98445 & 0.00952 & -0.11901 \\
\hline $\mathrm{O}$ & -0.15940 & 0.19959 & 0.83058 \\
\hline $\mathrm{O}$ & 0.73635 & -0.59390 & -1.48428 \\
\hline $\mathrm{C}$ & 2.48098 & 4.29920 & -1.69578 \\
\hline $\mathrm{C}$ & 3.21963 & 5.61783 & -1.99134 \\
\hline $\mathrm{C}$ & 2.26636 & 3.47658 & -2.97864 \\
\hline $\mathrm{C}$ & -2.00245 & 6.62572 & -1.58113 \\
\hline $\mathrm{C}$ & -2.26788 & 7.86178 & -0.70252 \\
\hline $\mathrm{C}$ & -3.31410 & 5.90576 & -1.94143 \\
\hline $\mathrm{C}$ & -0.65991 & 3.73753 & 2.35127 \\
\hline $\mathrm{C}$ & -1.88437 & 2.80914 & 2.28353 \\
\hline $\mathrm{C}$ & -0.85384 & 4.85856 & 3.38824 \\
\hline $\mathrm{C}$ & 0.79834 & -6.93793 & -0.70415 \\
\hline $\mathrm{C}$ & 1.41161 & -7.95966 & -1.67910 \\
\hline $\mathrm{C}$ & -0.65129 & -6.60289 & -1.10499 \\
\hline
\end{tabular}




\begin{tabular}{|c|c|c|c|}
\hline $\mathrm{C}$ & 2.71180 & -2.75280 & -2.83518 \\
\hline $\mathrm{C}$ & 1.47579 & -2.76475 & -3.74853 \\
\hline $\mathrm{C}$ & 3.96071 & -3.13770 & -3.65313 \\
\hline $\mathrm{C}$ & 3.66715 & -3.83740 & 2.08659 \\
\hline $\mathrm{C}$ & 4.47418 & -5.00562 & 2.67873 \\
\hline $\mathrm{C}$ & 2.58624 & -3.34777 & 3.07006 \\
\hline $\mathrm{H}$ & -5.21992 & 0.75276 & -0.51467 \\
\hline $\mathrm{H}$ & -3.45418 & -1.45129 & 2.73005 \\
\hline $\mathrm{H}$ & -3.34134 & 0.31025 & 2.80177 \\
\hline $\mathrm{H}$ & -2.31733 & -0.58038 & 1.67113 \\
\hline $\mathrm{H}$ & -6.26883 & 1.60585 & 1.34552 \\
\hline $\mathrm{H}$ & -8.49831 & 1.53577 & 2.38535 \\
\hline $\mathrm{H}$ & -7.91905 & -2.60884 & 3.34433 \\
\hline $\mathrm{H}$ & -5.69864 & -2.54980 & 2.29601 \\
\hline $\mathrm{H}$ & -10.10169 & 0.39224 & 3.86895 \\
\hline $\mathrm{H}$ & -9.78920 & -1.26431 & 4.41862 \\
\hline $\mathrm{H}$ & -10.50209 & -0.97917 & 2.82916 \\
\hline $\mathrm{H}$ & -4.37083 & 3.10078 & -1.90506 \\
\hline $\mathrm{H}$ & -4.89427 & 1.46280 & -2.37867 \\
\hline $\mathrm{H}$ & -4.49724 & 3.02880 & -4.32716 \\
\hline $\mathrm{H}$ & -3.62187 & 1.48127 & -4.40189 \\
\hline $\mathrm{H}$ & -1.27463 & 1.51221 & -3.98615 \\
\hline $\mathrm{H}$ & -0.51970 & 3.07118 & -3.57487 \\
\hline $\mathrm{H}$ & -1.51439 & 3.12713 & -1.39254 \\
\hline $\mathrm{H}$ & -0.83081 & 1.50201 & -1.60019 \\
\hline $\mathrm{H}$ & -4.32277 & -1.66059 & 0.52866 \\
\hline $\mathrm{H}$ & -4.88657 & -3.29386 & -0.00972 \\
\hline $\mathrm{H}$ & -0.52067 & -1.77326 & -1.30015 \\
\hline $\mathrm{H}$ & -2.64703 & -0.33631 & -3.36119 \\
\hline $\mathrm{H}$ & -0.99896 & -0.99860 & -3.18936 \\
\hline $\mathrm{H}$ & -2.28760 & -1.90344 & -4.04097 \\
\hline $\mathrm{H}$ & -0.08894 & -4.15191 & 1.10240 \\
\hline $\mathrm{H}$ & 0.59248 & -2.87342 & 0.12828 \\
\hline $\mathrm{H}$ & -0.17499 & -2.46720 & 1.65716 \\
\hline $\mathrm{H}$ & -7.06836 & -1.60499 & -2.42074 \\
\hline $\mathrm{H}$ & -6.48761 & -3.10454 & -1.64982 \\
\hline $\mathrm{H}$ & -6.45754 & -1.59357 & -0.74169 \\
\hline $\mathrm{H}$ & -2.59181 & -5.38995 & 3.31513 \\
\hline $\mathrm{H}$ & -1.39089 & -4.10692 & 3.02302 \\
\hline $\mathrm{H}$ & -1.46651 & -5.49819 & 1.93581 \\
\hline $\mathrm{H}$ & 5.96769 & 2.38435 & 0.37608 \\
\hline $\mathrm{H}$ & 7.90331 & -1.85613 & -1.35302 \\
\hline $\mathrm{H}$ & 9.28052 & 0.20267 & -1.27455 \\
\hline $\mathrm{H}$ & 8.28123 & 2.32873 & -0.43285 \\
\hline $\mathrm{H}$ & 5.77739 & -3.00617 & -0.96623 \\
\hline $\mathrm{H}$ & 2.30599 & 4.89074 & 2.44715 \\
\hline
\end{tabular}




\begin{tabular}{|c|c|c|c|}
\hline $\mathrm{H}$ & 5.66416 & 0.46694 & 2.69558 \\
\hline $\mathrm{H}$ & 6.63996 & 1.52903 & 4.68342 \\
\hline $\mathrm{H}$ & 5.79346 & 3.73499 & 5.48479 \\
\hline $\mathrm{H}$ & 3.92272 & 4.84173 & 4.29544 \\
\hline $\mathrm{H}$ & 2.16969 & -6.00484 & 1.45916 \\
\hline $\mathrm{H}$ & 1.33446 & -5.08199 & -2.62791 \\
\hline $\mathrm{H}$ & -2.18427 & 5.34413 & 0.83415 \\
\hline $\mathrm{H}$ & 0.39777 & 5.77465 & -2.54539 \\
\hline $\mathrm{H}$ & 3.13596 & 3.71184 & -1.04822 \\
\hline $\mathrm{H}$ & 3.39262 & 6.18597 & -1.07044 \\
\hline $\mathrm{H}$ & 4.19160 & 5.41357 & -2.45608 \\
\hline $\mathrm{H}$ & 2.65094 & 6.25646 & -2.67729 \\
\hline $\mathrm{H}$ & 1.79301 & 2.51782 & -2.74705 \\
\hline $\mathrm{H}$ & 1.64096 & 4.01942 & -3.69866 \\
\hline $\mathrm{H}$ & 3.22744 & 3.27148 & -3.46525 \\
\hline $\mathrm{H}$ & -1.55367 & 6.97710 & -2.52027 \\
\hline $\mathrm{H}$ & -1.33512 & 8.38306 & -0.46081 \\
\hline $\mathrm{H}$ & -2.93316 & 8.56550 & -1.21693 \\
\hline $\mathrm{H}$ & -2.74747 & 7.58034 & 0.24248 \\
\hline $\mathrm{H}$ & -3.12128 & 5.08676 & -2.64014 \\
\hline $\mathrm{H}$ & -3.79201 & 5.49293 & -1.04346 \\
\hline $\mathrm{H}$ & -4.02325 & 6.60120 & -2.40708 \\
\hline $\mathrm{H}$ & 0.17741 & 3.12012 & 2.68618 \\
\hline $\mathrm{H}$ & -1.65655 & 1.94781 & 1.65323 \\
\hline $\mathrm{H}$ & -2.13438 & 2.43947 & 3.28584 \\
\hline $\mathrm{H}$ & -2.76901 & 3.32088 & 1.88516 \\
\hline $\mathrm{H}$ & 0.03518 & 5.49633 & 3.45530 \\
\hline $\mathrm{H}$ & -1.70429 & 5.50161 & 3.13166 \\
\hline $\mathrm{H}$ & -1.04433 & 4.43336 & 4.38082 \\
\hline $\mathrm{H}$ & 0.76885 & -7.40390 & 0.29087 \\
\hline $\mathrm{H}$ & 2.42996 & -8.22797 & -1.37788 \\
\hline $\mathrm{H}$ & 1.46084 & -7.54926 & -2.69469 \\
\hline $\mathrm{H}$ & 0.80944 & -8.87548 & -1.71544 \\
\hline $\mathrm{H}$ & -0.69249 & -6.16321 & -2.10827 \\
\hline $\mathrm{H}$ & -1.27102 & -7.50730 & -1.11196 \\
\hline $\mathrm{H}$ & -1.10573 & -5.88276 & -0.41539 \\
\hline $\mathrm{H}$ & 2.83066 & -1.72622 & -2.47754 \\
\hline $\mathrm{H}$ & 0.55807 & -2.64583 & -3.17059 \\
\hline $\mathrm{H}$ & 1.53527 & -1.93767 & -4.46405 \\
\hline $\mathrm{H}$ & 1.40087 & -3.69417 & -4.32686 \\
\hline $\mathrm{H}$ & 4.87780 & -3.03536 & -3.06752 \\
\hline $\mathrm{H}$ & 3.89056 & -4.17776 & -3.99559 \\
\hline $\mathrm{H}$ & 4.05177 & -2.49441 & -4.53678 \\
\hline $\mathrm{H}$ & 4.36651 & -3.00918 & 1.93715 \\
\hline $\mathrm{H}$ & 5.23683 & -5.35708 & 1.97484 \\
\hline $\mathrm{H}$ & 4.97740 & -4.68860 & 3.59967 \\
\hline
\end{tabular}




$\begin{array}{llll}\mathrm{H} & 3.83401 & -5.85848 & 2.93296 \\ \mathrm{H} & 2.07809 & -2.46309 & 2.67582 \\ \mathrm{H} & 1.83641 & -4.13000 & 3.24579 \\ \mathrm{H} & 3.03350 & -3.08708 & 4.03693\end{array}$

\section{TS7-Z}

B3LYP-D3/6-31G(d) Energy $=-3928.737052$

B3LYP-D3/6-31G(d) Free Energy $=-3927.344842$

Number of Imaginary Frequencies $=1(-1045.93)$

$\begin{array}{lccc}\text { B3LYP-D } 3 / 6-31 G(d) \text { Geometry } & \\ \text { C } & -5.90584 & 0.02349 & 0.83739 \\ \text { C } & -5.54270 & -1.18283 & 1.54497 \\ \text { C } & -5.28465 & 1.24514 & 0.95172 \\ \text { N } & -5.52868 & 2.35996 & 0.23831 \\ \text { C } & -6.40223 & 2.43581 & -0.93526 \\ \text { C } & -5.65959 & 3.14461 & -2.07402 \\ \text { O } & -5.16435 & 4.41399 & -1.66706 \\ \text { C } & -4.26335 & 4.29005 & -0.57559 \\ \text { C } & -4.95605 & 3.64926 & 0.62550 \\ \text { H } & -4.52529 & 1.37969 & 1.71626 \\ \text { C } & -4.43242 & -2.56660 & -0.51181 \\ \text { C } & -3.22713 & -3.13925 & 0.09040 \\ \text { C } & -2.00397 & -2.57281 & -0.20639 \\ \text { N } & -1.95846 & -1.53273 & -1.09777 \\ \text { C } & -3.02338 & -0.98231 & -1.73582 \\ \text { C } & -4.28518 & -1.52243 & -1.52102 \\ \text { C } & -2.68301 & 0.16307 & -2.64644 \\ \text { C } & -0.66535 & -2.92287 & 0.35959 \\ \text { C } & -5.47083 & -1.02729 & -2.24850 \\ \text { C } & -3.50918 & -4.20134 & 1.09727 \\ \text { C } & -6.73250 & -1.88126 & -2.21314 \\ \text { O } & -5.47513 & 0.02510 & -2.88877 \\ \text { C } & -2.45117 & -4.75998 & 2.02933 \\ \text { O } & -4.66966 & -4.59347 & 1.21365 \\ \text { C } & 5.65871 & 1.02505 & 2.45114 \\ \text { C } & 4.60509 & 1.74951 & 1.82879 \\ \text { C } & 4.26189 & 3.03486 & 2.36010 \\ \text { C } & 5.00711 & 3.55915 & 3.45007 \\ \text { C } & 6.03333 & 2.83941 & 4.01775 \\ \text { C } & 6.35215 & 1.55476 & 3.51684 \\ \text { C } & 3.85676 & 1.23610 & 0.71606 \\ \text { C } & 2.74002 & 1.93869 & 0.29111 \\ \text { C } & 2.39926 & 3.22590 & 0.78735 \\ \text { C } & 3.18310 & 3.75717 & 1.78908 \\ \text { C } & 4.24217 & -0.01483 & 0.00824 \\ & & & \end{array}$




\begin{tabular}{|c|c|c|c|}
\hline $\mathrm{C}$ & 5.54399 & -0.16649 & -0.58057 \\
\hline $\mathrm{C}$ & 5.89757 & -1.42363 & -1.16775 \\
\hline $\mathrm{C}$ & 4.93690 & -2.46445 & -1.20085 \\
\hline $\mathrm{C}$ & 3.65123 & -2.28906 & -0.73596 \\
\hline $\mathrm{C}$ & 3.31698 & -1.04072 & -0.13687 \\
\hline $\mathrm{C}$ & 6.49864 & 0.88744 & -0.63594 \\
\hline $\mathrm{C}$ & 7.73987 & 0.69387 & -1.20040 \\
\hline $\mathrm{C}$ & 8.09986 & -0.56328 & -1.74151 \\
\hline $\mathrm{C}$ & 7.19175 & -1.59641 & -1.72770 \\
\hline $\mathrm{C}$ & 1.28019 & 4.02266 & 0.19515 \\
\hline $\mathrm{O}$ & 2.05086 & -0.89489 & 0.38985 \\
\hline $\mathrm{O}$ & 1.95168 & 1.40831 & -0.71296 \\
\hline $\mathrm{C}$ & 2.66827 & -3.41488 & -0.83249 \\
\hline $\mathrm{C}$ & 1.45350 & 4.63309 & -1.06737 \\
\hline $\mathrm{C}$ & 0.46393 & 5.49896 & -1.53809 \\
\hline $\mathrm{C}$ & -0.68290 & 5.79288 & -0.79570 \\
\hline $\mathrm{C}$ & -0.85519 & 5.13454 & 0.42356 \\
\hline $\mathrm{C}$ & 0.09366 & 4.23433 & 0.92723 \\
\hline $\mathrm{C}$ & 2.49027 & -4.28518 & 0.26242 \\
\hline $\mathrm{C}$ & 1.63051 & -5.38225 & 0.12093 \\
\hline $\mathrm{C}$ & 0.93923 & -5.63269 & -1.06469 \\
\hline $\mathrm{C}$ & 1.12392 & -4.74810 & -2.13152 \\
\hline $\mathrm{C}$ & 1.96586 & -3.63602 & -2.04070 \\
\hline $\mathrm{P}$ & 0.94539 & 0.16185 & -0.29127 \\
\hline $\mathrm{O}$ & 0.44588 & -0.41052 & -1.59955 \\
\hline $\mathrm{O}$ & -0.01299 & 0.52097 & 0.79841 \\
\hline $\mathrm{C}$ & 2.11891 & -2.69687 & -3.23460 \\
\hline $\mathrm{C}$ & 0.80067 & -2.46093 & -3.99068 \\
\hline $\mathrm{C}$ & 3.20000 & -3.21414 & -4.20354 \\
\hline $\mathrm{C}$ & -0.00172 & -6.82248 & -1.18641 \\
\hline $\mathrm{C}$ & 0.55777 & -7.87780 & -2.15835 \\
\hline $\mathrm{C}$ & -1.42256 & -6.39749 & -1.60273 \\
\hline $\mathrm{C}$ & 3.16646 & -4.03023 & 1.60640 \\
\hline $\mathrm{C}$ & 3.88736 & -5.27429 & 2.15311 \\
\hline $\mathrm{C}$ & 2.14987 & -3.47815 & 2.62700 \\
\hline $\mathrm{C}$ & -1.68058 & 6.83233 & -1.28754 \\
\hline $\mathrm{C}$ & -2.29874 & 6.46404 & -2.64871 \\
\hline $\mathrm{C}$ & -1.03232 & 8.22934 & -1.34379 \\
\hline $\mathrm{C}$ & -0.17053 & 3.50841 & 2.24393 \\
\hline $\mathrm{C}$ & -1.57293 & 2.87796 & 2.28398 \\
\hline $\mathrm{C}$ & 0.03802 & 4.43661 & 3.45422 \\
\hline $\mathrm{C}$ & 2.68375 & 4.37995 & -1.93386 \\
\hline $\mathrm{C}$ & 3.43282 & 5.68309 & -2.26619 \\
\hline $\mathrm{C}$ & 2.30268 & 3.60536 & -3.20955 \\
\hline $\mathrm{H}$ & -6.76527 & -0.05997 & 0.17936 \\
\hline $\mathrm{H}$ & -7.30849 & 2.99790 & -0.67002 \\
\hline
\end{tabular}




\begin{tabular}{|c|c|c|c|}
\hline $\mathrm{H}$ & -6.67942 & 1.43695 & -1.26770 \\
\hline $\mathrm{H}$ & -4.84482 & 2.49635 & -2.42447 \\
\hline $\mathrm{H}$ & -6.34225 & 3.32357 & -2.90894 \\
\hline $\mathrm{H}$ & -3.37952 & 3.69620 & -0.85779 \\
\hline $\mathrm{H}$ & -3.93168 & 5.29909 & -0.32539 \\
\hline $\mathrm{H}$ & -5.76368 & 4.30884 & 0.97371 \\
\hline $\mathrm{H}$ & -4.24842 & 3.50006 & 1.44298 \\
\hline $\mathrm{H}$ & -5.00593 & -1.95839 & 0.49366 \\
\hline $\mathrm{H}$ & -5.23414 & -3.29173 & -0.64725 \\
\hline $\mathrm{H}$ & -1.01512 & -1.10650 & -1.29009 \\
\hline $\mathrm{H}$ & -1.60031 & 0.25908 & -2.75349 \\
\hline $\mathrm{H}$ & -3.16092 & 0.04483 & -3.62080 \\
\hline $\mathrm{H}$ & -3.07839 & 1.09212 & -2.22339 \\
\hline $\mathrm{H}$ & -0.50941 & -2.36683 & 1.28948 \\
\hline $\mathrm{H}$ & -0.55604 & -3.98124 & 0.56075 \\
\hline $\mathrm{H}$ & 0.12876 & -2.63611 & -0.32664 \\
\hline $\mathrm{H}$ & -6.53298 & -2.89175 & -2.59014 \\
\hline $\mathrm{H}$ & -7.12134 & -1.99255 & -1.19539 \\
\hline $\mathrm{H}$ & -7.48946 & -1.40381 & -2.83781 \\
\hline $\mathrm{H}$ & -1.72053 & -5.37423 & 1.49222 \\
\hline $\mathrm{H}$ & -2.96183 & -5.38336 & 2.76550 \\
\hline $\mathrm{H}$ & -1.91001 & -3.95818 & 2.54071 \\
\hline $\mathrm{H}$ & 5.90848 & 0.03742 & 2.08031 \\
\hline $\mathrm{H}$ & 4.74065 & 4.54070 & 3.83555 \\
\hline $\mathrm{H}$ & 6.59225 & 3.24859 & 4.85501 \\
\hline $\mathrm{H}$ & 7.14898 & 0.97891 & 3.97997 \\
\hline $\mathrm{H}$ & 2.96553 & 4.75557 & 2.15853 \\
\hline $\mathrm{H}$ & 5.21914 & -3.42569 & -1.62223 \\
\hline $\mathrm{H}$ & 6.23680 & 1.85940 & -0.23479 \\
\hline $\mathrm{H}$ & 8.44790 & 1.51754 & -1.23573 \\
\hline $\mathrm{H}$ & 9.08477 & -0.70383 & -2.17845 \\
\hline $\mathrm{H}$ & 7.44472 & -2.56191 & -2.15994 \\
\hline $\mathrm{H}$ & 0.60506 & 5.97805 & -2.50337 \\
\hline $\mathrm{H}$ & -1.74941 & 5.34055 & 1.00829 \\
\hline $\mathrm{H}$ & 1.48205 & -6.05194 & 0.96542 \\
\hline $\mathrm{H}$ & 0.58792 & -4.92476 & -3.05887 \\
\hline $\mathrm{H}$ & 2.43605 & -1.72383 & -2.84910 \\
\hline $\mathrm{H}$ & 0.00636 & -2.16187 & -3.30427 \\
\hline $\mathrm{H}$ & 0.93520 & -1.65394 & -4.71934 \\
\hline $\mathrm{H}$ & 0.47748 & -3.35118 & -4.54454 \\
\hline $\mathrm{H}$ & 4.17449 & -3.29755 & -3.71367 \\
\hline $\mathrm{H}$ & 2.92960 & -4.20492 & -4.59014 \\
\hline $\mathrm{H}$ & 3.30782 & -2.53407 & -5.05714 \\
\hline $\mathrm{H}$ & -0.07193 & -7.28887 & -0.19332 \\
\hline $\mathrm{H}$ & 1.55089 & -8.21552 & -1.84294 \\
\hline $\mathrm{H}$ & -0.10359 & -8.75108 & -2.21213 \\
\hline
\end{tabular}




\begin{tabular}{|c|c|c|c|}
\hline $\mathrm{H}$ & 0.65153 & -7.46244 & -3.16888 \\
\hline $\mathrm{H}$ & -1.83003 & -5.63396 & -0.93137 \\
\hline $\mathrm{H}$ & -1.42996 & -5.97776 & -2.61522 \\
\hline $\mathrm{H}$ & -2.10204 & -7.25780 & -1.59482 \\
\hline $\mathrm{H}$ & 3.92735 & -3.25770 & 1.45912 \\
\hline $\mathrm{H}$ & 4.60322 & -5.66853 & 1.42327 \\
\hline $\mathrm{H}$ & 4.43485 & -5.02281 & 3.06908 \\
\hline $\mathrm{H}$ & 3.18490 & -6.07842 & 2.40192 \\
\hline $\mathrm{H}$ & 1.71796 & -2.53991 & 2.26672 \\
\hline $\mathrm{H}$ & 1.33664 & -4.19609 & 2.79539 \\
\hline $\mathrm{H}$ & 2.63696 & -3.28735 & 3.59132 \\
\hline $\mathrm{H}$ & -2.49455 & 6.88607 & -0.55074 \\
\hline $\mathrm{H}$ & -2.82757 & 5.50687 & -2.61193 \\
\hline $\mathrm{H}$ & -1.52580 & 6.39270 & -3.42267 \\
\hline $\mathrm{H}$ & -3.01671 & 7.23033 & -2.96454 \\
\hline $\mathrm{H}$ & -0.21649 & 8.25222 & -2.07572 \\
\hline $\mathrm{H}$ & -1.76793 & 8.98849 & -1.63627 \\
\hline $\mathrm{H}$ & -0.61437 & 8.50907 & -0.37057 \\
\hline $\mathrm{H}$ & 0.53906 & 2.68002 & 2.31341 \\
\hline $\mathrm{H}$ & -1.73570 & 2.25845 & 1.39827 \\
\hline $\mathrm{H}$ & -1.67386 & 2.23470 & 3.16556 \\
\hline $\mathrm{H}$ & -2.35255 & 3.64778 & 2.34855 \\
\hline $\mathrm{H}$ & 1.06136 & 4.82318 & 3.49116 \\
\hline $\mathrm{H}$ & -0.64270 & 5.29630 & 3.40920 \\
\hline $\mathrm{H}$ & -0.15546 & 3.90069 & 4.39177 \\
\hline $\mathrm{H}$ & 3.37901 & 3.75138 & -1.37090 \\
\hline $\mathrm{H}$ & 3.71670 & 6.21847 & -1.35298 \\
\hline $\mathrm{H}$ & 4.34553 & 5.46359 & -2.83299 \\
\hline $\mathrm{H}$ & 2.82076 & 6.35958 & -2.87433 \\
\hline $\mathrm{H}$ & 1.81944 & 2.65840 & -2.95291 \\
\hline $\mathrm{H}$ & 1.61581 & 4.18881 & -3.83523 \\
\hline $\mathrm{H}$ & 3.19711 & 3.38715 & -3.80590 \\
\hline $\mathrm{C}$ & -2.02917 & -1.40543 & 4.07997 \\
\hline $\mathrm{C}$ & -1.98717 & -0.73990 & 2.84723 \\
\hline $\mathrm{C}$ & -3.12032 & -0.66228 & 2.04335 \\
\hline $\mathrm{C}$ & -4.35462 & -1.21792 & 2.44356 \\
\hline $\mathrm{C}$ & -4.38286 & -1.89421 & 3.67698 \\
\hline $\mathrm{C}$ & -3.24564 & -1.97757 & 4.47767 \\
\hline $\mathrm{C}$ & -0.78591 & -1.50546 & 4.92973 \\
\hline $\mathrm{H}$ & -1.06594 & -0.29639 & 2.47817 \\
\hline $\mathrm{H}$ & -3.02072 & -0.18843 & 1.07313 \\
\hline $\mathrm{H}$ & -5.29925 & -2.35971 & 4.02245 \\
\hline $\mathrm{H}$ & -3.30408 & -2.50498 & 5.42700 \\
\hline $\mathrm{H}$ & -0.47419 & -0.51585 & 5.28625 \\
\hline $\mathrm{H}$ & -0.94066 & -2.14581 & 5.80398 \\
\hline $\mathrm{H}$ & 0.05334 & -1.91105 & 4.35179 \\
\hline
\end{tabular}




$\begin{array}{llll}\text { C } & -6.71829 & -2.08645 & 1.90750 \\ \mathrm{H} & -6.39577 & -3.11321 & 2.08829 \\ \mathrm{H} & -7.22315 & -1.70004 & 2.80224 \\ \mathrm{H} & -7.45779 & -2.09633 & 1.10076\end{array}$

\section{TS8-E}

B3LYP-D3/6-31G(d) Energy = -3928.748197

B3LYP-D3/6-31G(d) Free Energy = -3927.355985

Number of Imaginary Frequencies $=1(-1083.87)$

$\begin{array}{lccc}\text { B3LYP-D3/6-31G(d) Geometry } & \\ \mathrm{C} & 2.60858 & -3.10850 & 0.39852 \\ \mathrm{C} & 3.78050 & -2.96224 & 1.22667 \\ \mathrm{C} & 2.52828 & -3.85156 & -0.75558 \\ \mathrm{C} & 3.60589 & -2.19955 & 2.50552 \\ \mathrm{C} & 4.80817 & -4.09105 & 1.23344 \\ \mathrm{C} & 2.56333 & -1.26517 & 2.66536 \\ \mathrm{C} & 2.43472 & -0.52324 & 3.83757 \\ \mathrm{C} & 3.34495 & -0.65840 & 4.89145 \\ \mathrm{C} & 4.39245 & -1.57633 & 4.72907 \\ \mathrm{C} & 4.52144 & -2.32813 & 3.56646 \\ \mathrm{C} & 3.19609 & 0.13636 & 6.16523 \\ \mathrm{~N} & 1.45712 & -3.93159 & -1.57620 \\ \mathrm{C} & 1.39741 & -4.98230 & -2.59689 \\ \mathrm{C} & 0.53309 & -4.53487 & -3.77729 \\ \mathrm{O} & -0.75287 & -4.12609 & -3.34598 \\ \mathrm{C} & -0.66057 & -3.01407 & -2.45324 \\ \mathrm{C} & 0.15477 & -3.35386 & -1.21191 \\ \mathrm{H} & 3.37307 & -4.44257 & -1.09625 \\ \mathrm{C} & 5.02573 & -1.08217 & -0.26320 \\ \mathrm{C} & 4.53305 & 0.12106 & 0.40821 \\ \mathrm{C} & 3.32181 & 0.63369 & -0.00737 \\ \mathrm{~N} & 2.74020 & 0.10606 & -1.13770 \\ \mathrm{C} & 3.28347 & -0.84702 & -1.94036 \\ \mathrm{C} & 4.48816 & -1.42872 & -1.56562 \\ \mathrm{C} & 2.51546 & -1.15369 & -3.18867 \\ \mathrm{C} & 2.50500 & 1.70575 & 0.64335 \\ \mathrm{C} & 5.14308 & -2.46806 & -2.39638 \\ \mathrm{C} & 5.35163 & 0.53651 & 1.58379 \\ \mathrm{C} & 6.56266 & -2.88060 & -2.02935 \\ \mathrm{O} & 4.58480 & -3.00465 & -3.35076 \\ \mathrm{C} & 4.99297 & 1.72334 & 2.45666 \\ \mathrm{O} & 6.35582 & -0.11846 & 1.85276 \\ \mathrm{C} & -5.34976 & 3.18012 & -0.90966 \\ \mathrm{C} & -3.95144 & 3.41567 & -0.79612\end{array}$




\begin{tabular}{|c|c|c|c|}
\hline $\mathrm{C}$ & -3.41532 & 4.59445 & -1.40517 \\
\hline $\mathrm{C}$ & -4.29030 & 5.50873 & -2.05070 \\
\hline $\mathrm{C}$ & -5.64147 & 5.26086 & -2.12426 \\
\hline $\mathrm{C}$ & -6.17028 & 4.07674 & -1.55731 \\
\hline $\mathrm{C}$ & -3.05905 & 2.51723 & -0.11790 \\
\hline $\mathrm{C}$ & -1.69179 & 2.73008 & -0.21336 \\
\hline $\mathrm{C}$ & -1.14381 & 3.89673 & -0.82095 \\
\hline $\mathrm{C}$ & -2.01666 & 4.81640 & -1.36207 \\
\hline $\mathrm{C}$ & -3.57660 & 1.37144 & 0.67535 \\
\hline $\mathrm{C}$ & -4.51096 & 1.57432 & 1.74822 \\
\hline $\mathrm{C}$ & -5.10094 & 0.43301 & 2.37848 \\
\hline $\mathrm{C}$ & -4.72343 & -0.86266 & 1.94794 \\
\hline $\mathrm{C}$ & -3.74537 & -1.06364 & 0.99759 \\
\hline $\mathrm{C}$ & -3.15379 & 0.08077 & 0.39192 \\
\hline $\mathrm{C}$ & -4.86126 & 2.86387 & 2.23635 \\
\hline $\mathrm{C}$ & -5.76658 & 3.01277 & 3.26351 \\
\hline $\mathrm{C}$ & -6.37634 & 1.88258 & 3.85842 \\
\hline $\mathrm{C}$ & -6.04437 & 0.62021 & 3.42401 \\
\hline $\mathrm{C}$ & 0.32661 & 4.17790 & -0.81870 \\
\hline $\mathrm{O}$ & -2.18825 & -0.11973 & -0.58140 \\
\hline $\mathrm{O}$ & -0.82842 & 1.83338 & 0.38812 \\
\hline $\mathrm{C}$ & -3.39550 & -2.45469 & 0.57488 \\
\hline $\mathrm{C}$ & 0.92371 & 4.75129 & 0.32291 \\
\hline $\mathrm{C}$ & 2.29150 & 5.05237 & 0.29110 \\
\hline $\mathrm{C}$ & 3.07981 & 4.79606 & -0.83015 \\
\hline $\mathrm{C}$ & 2.46283 & 4.23259 & -1.95132 \\
\hline $\mathrm{C}$ & 1.10296 & 3.91024 & -1.97118 \\
\hline $\mathrm{C}$ & -3.97209 & -2.98701 & -0.59762 \\
\hline $\mathrm{C}$ & -3.68880 & -4.31246 & -0.94935 \\
\hline $\mathrm{C}$ & -2.87857 & -5.12863 & -0.15834 \\
\hline $\mathrm{C}$ & -2.33501 & -4.57985 & 1.00784 \\
\hline $\mathrm{C}$ & -2.55563 & -3.25144 & 1.38399 \\
\hline $\mathrm{P}$ & -0.61422 & 0.31115 & -0.26533 \\
\hline $\mathrm{O}$ & 0.00122 & -0.53014 & 0.81176 \\
\hline $\mathrm{O}$ & 0.05921 & 0.43099 & -1.61442 \\
\hline $\mathrm{C}$ & -1.90737 & -2.69675 & 2.65021 \\
\hline $\mathrm{C}$ & -0.44852 & -3.14698 & 2.81948 \\
\hline $\mathrm{C}$ & -2.72618 & -3.07094 & 3.90052 \\
\hline $\mathrm{C}$ & -2.59726 & -6.58402 & -0.50766 \\
\hline $\mathrm{C}$ & -2.53434 & -6.85332 & -2.01935 \\
\hline $\mathrm{C}$ & -3.62878 & -7.50549 & 0.17285 \\
\hline $\mathrm{C}$ & -4.89162 & -2.15919 & -1.49339 \\
\hline $\mathrm{C}$ & -6.23405 & -2.86817 & -1.74896 \\
\hline $\mathrm{C}$ & -4.19926 & -1.78117 & -2.81680 \\
\hline $\mathrm{C}$ & 4.57018 & 5.10252 & -0.82860 \\
\hline $\mathrm{C}$ & 4.90512 & 6.25364 & -1.79500 \\
\hline
\end{tabular}




\begin{tabular}{|c|c|c|c|}
\hline $\mathrm{C}$ & 5.41515 & 3.85560 & -1.15200 \\
\hline $\mathrm{C}$ & 0.48663 & 3.27971 & -3.21779 \\
\hline $\mathrm{C}$ & 1.45756 & 2.34543 & -3.95835 \\
\hline $\mathrm{C}$ & -0.03376 & 4.35444 & -4.19253 \\
\hline $\mathrm{C}$ & 0.13326 & 5.00327 & 1.60353 \\
\hline $\mathrm{C}$ & 0.29136 & 6.44524 & 2.11623 \\
\hline $\mathrm{C}$ & 0.51350 & 3.97640 & 2.68869 \\
\hline $\mathrm{H}$ & 1.75565 & -2.49447 & 0.64705 \\
\hline $\mathrm{H}$ & 4.49091 & -4.88412 & 1.92067 \\
\hline $\mathrm{H}$ & 5.79284 & -3.73629 & 1.54909 \\
\hline $\mathrm{H}$ & 4.92437 & -4.53547 & 0.24267 \\
\hline $\mathrm{H}$ & 1.82087 & -1.09706 & 1.89461 \\
\hline $\mathrm{H}$ & 1.60514 & 0.17558 & 3.92155 \\
\hline $\mathrm{H}$ & 5.12345 & -1.70012 & 5.52466 \\
\hline $\mathrm{H}$ & 5.35768 & -3.01330 & 3.48964 \\
\hline $\mathrm{H}$ & 2.67699 & -0.44917 & 6.93572 \\
\hline $\mathrm{H}$ & 2.61414 & 1.04945 & 6.00236 \\
\hline $\mathrm{H}$ & 4.17110 & 0.42044 & 6.57652 \\
\hline $\mathrm{H}$ & 0.95880 & -5.89312 & -2.16059 \\
\hline $\mathrm{H}$ & 2.41364 & -5.20359 & -2.93764 \\
\hline $\mathrm{H}$ & 1.03456 & -3.72003 & -4.32351 \\
\hline $\mathrm{H}$ & 0.38749 & -5.37344 & -4.46482 \\
\hline $\mathrm{H}$ & -0.23125 & -2.14522 & -2.96988 \\
\hline $\mathrm{H}$ & -1.67553 & -2.76847 & -2.14699 \\
\hline $\mathrm{H}$ & -0.39333 & -4.07616 & -0.59666 \\
\hline $\mathrm{H}$ & 0.29073 & -2.44577 & -0.62510 \\
\hline $\mathrm{H}$ & 4.52203 & -2.02941 & 0.52375 \\
\hline $\mathrm{H}$ & 6.07675 & -1.28327 & -0.07286 \\
\hline $\mathrm{H}$ & 1.75412 & 0.37993 & -1.35033 \\
\hline $\mathrm{H}$ & 2.27250 & -2.21523 & -3.21017 \\
\hline $\mathrm{H}$ & 1.59973 & -0.56416 & -3.23501 \\
\hline $\mathrm{H}$ & 3.13341 & -0.96336 & -4.07136 \\
\hline $\mathrm{H}$ & 1.73604 & 2.07157 & -0.03309 \\
\hline $\mathrm{H}$ & 2.00291 & 1.30381 & 1.52807 \\
\hline $\mathrm{H}$ & 3.10488 & 2.56060 & 0.93968 \\
\hline $\mathrm{H}$ & 6.59998 & -3.34983 & -1.03950 \\
\hline $\mathrm{H}$ & 6.91736 & -3.59286 & -2.77614 \\
\hline $\mathrm{H}$ & 7.23324 & -2.01374 & -1.99908 \\
\hline $\mathrm{H}$ & 4.97666 & 2.65703 & 1.88394 \\
\hline $\mathrm{H}$ & 5.74971 & 1.79489 & 3.23987 \\
\hline $\mathrm{H}$ & 4.00992 & 1.58864 & 2.91570 \\
\hline $\mathrm{H}$ & -5.76851 & 2.27450 & -0.48634 \\
\hline $\mathrm{H}$ & -3.86614 & 6.40410 & -2.49939 \\
\hline $\mathrm{H}$ & -6.30142 & 5.96273 & -2.62674 \\
\hline $\mathrm{H}$ & -7.23412 & 3.87027 & -1.63792 \\
\hline $\mathrm{H}$ & -1.61939 & 5.73730 & -1.78007 \\
\hline
\end{tabular}




\begin{tabular}{|c|c|c|c|}
\hline $\mathrm{H}$ & -5.21623 & -1.72581 & 2.38660 \\
\hline $\mathrm{H}$ & -4.39734 & 3.73897 & 1.79633 \\
\hline $\mathrm{H}$ & -6.01156 & 4.00836 & 3.62373 \\
\hline $\mathrm{H}$ & -7.09408 & 2.01477 & 4.66346 \\
\hline $\mathrm{H}$ & -6.48979 & -0.25895 & 3.88395 \\
\hline $\mathrm{H}$ & 2.76041 & 5.48012 & 1.17471 \\
\hline $\mathrm{H}$ & 3.06375 & 4.02731 & -2.83159 \\
\hline $\mathrm{H}$ & -4.11077 & -4.70976 & -1.86681 \\
\hline $\mathrm{H}$ & -1.69864 & -5.20725 & 1.62755 \\
\hline $\mathrm{H}$ & -1.88910 & -1.60652 & 2.56032 \\
\hline $\mathrm{H}$ & 0.12204 & -2.94595 & 1.91281 \\
\hline $\mathrm{H}$ & 0.02356 & -2.59475 & 3.63897 \\
\hline $\mathrm{H}$ & -0.36861 & -4.21554 & 3.05423 \\
\hline $\mathrm{H}$ & -2.25295 & -2.66873 & 4.80468 \\
\hline $\mathrm{H}$ & -2.78984 & -4.16115 & 4.00743 \\
\hline $\mathrm{H}$ & -3.74608 & -2.67841 & 3.85014 \\
\hline $\mathrm{H}$ & -1.61040 & -6.82798 & -0.08681 \\
\hline $\mathrm{H}$ & -1.88483 & -6.13182 & -2.52500 \\
\hline $\mathrm{H}$ & -2.16133 & -7.86708 & -2.20783 \\
\hline $\mathrm{H}$ & -3.52832 & -6.78613 & -2.47802 \\
\hline $\mathrm{H}$ & -3.63768 & -7.35711 & 1.25839 \\
\hline $\mathrm{H}$ & -4.63666 & -7.29049 & -0.20259 \\
\hline $\mathrm{H}$ & -3.40724 & -8.56058 & -0.03016 \\
\hline $\mathrm{H}$ & -5.12136 & -1.22554 & -0.97113 \\
\hline $\mathrm{H}$ & -6.72412 & -3.13833 & -0.80675 \\
\hline $\mathrm{H}$ & -6.90854 & -2.21125 & -2.31086 \\
\hline $\mathrm{H}$ & -6.10508 & -3.78556 & -2.33495 \\
\hline $\mathrm{H}$ & -3.31176 & -1.17005 & -2.62812 \\
\hline $\mathrm{H}$ & -3.89307 & -2.67609 & -3.37276 \\
\hline $\mathrm{H}$ & -4.88075 & -1.20482 & -3.45439 \\
\hline $\mathrm{H}$ & 4.83714 & 5.43090 & 0.18585 \\
\hline $\mathrm{H}$ & 4.33672 & 7.15575 & -1.54415 \\
\hline $\mathrm{H}$ & 4.65697 & 5.97869 & -2.82715 \\
\hline $\mathrm{H}$ & 5.97384 & 6.49715 & -1.75860 \\
\hline $\mathrm{H}$ & 5.23349 & 3.50856 & -2.17582 \\
\hline $\mathrm{H}$ & 6.48477 & 4.07884 & -1.06223 \\
\hline $\mathrm{H}$ & 5.18186 & 3.02251 & -0.48003 \\
\hline $\mathrm{H}$ & -0.35668 & 2.66492 & -2.88997 \\
\hline $\mathrm{H}$ & 1.97418 & 1.68158 & -3.26328 \\
\hline $\mathrm{H}$ & 0.90621 & 1.72764 & -4.67520 \\
\hline $\mathrm{H}$ & 2.21580 & 2.90378 & -4.52154 \\
\hline $\mathrm{H}$ & -0.81493 & 4.97058 & -3.74079 \\
\hline $\mathrm{H}$ & 0.78311 & 5.01670 & -4.50584 \\
\hline $\mathrm{H}$ & -0.45322 & 3.88442 & -5.09035 \\
\hline $\mathrm{H}$ & -0.92791 & 4.85818 & 1.37980 \\
\hline $\mathrm{H}$ & 0.02013 & 7.17179 & 1.34214 \\
\hline
\end{tabular}




$\begin{array}{lrrr}\mathrm{H} & -0.35656 & 6.61166 & 2.98485 \\ \mathrm{H} & 1.32047 & 6.65727 & 2.42908 \\ \mathrm{H} & 0.31172 & 2.95899 & 2.34159 \\ \mathrm{H} & 1.57816 & 4.05333 & 2.94438 \\ \mathrm{H} & -0.06623 & 4.15064 & 3.60335\end{array}$

\section{TS8-Z}

B3LYP-D3/6-31G(d) Energy $=-3928.737731$

B3LYP-D3/6-31G(d) Free Energy $=-3927.345299$

Number of Imaginary Frequencies $=1(-1098.29)$

$\begin{array}{lccc}\text { B3LYP-D3/6-31G(d) Geometry } & \\ \mathrm{C} & 3.52578 & 0.14867 & -0.26654 \\ \mathrm{C} & 4.28280 & -0.61862 & -1.21387 \\ \mathrm{C} & 4.02168 & 0.59000 & 0.94449 \\ \mathrm{C} & 5.77613 & -0.48027 & -1.34405 \\ \mathrm{C} & 3.56865 & -0.86331 & -2.54109 \\ \mathrm{C} & 6.43631 & 0.73118 & -1.09566 \\ \mathrm{C} & 7.81678 & 0.84253 & -1.26832 \\ \mathrm{C} & 8.58479 & -0.24505 & -1.69624 \\ \mathrm{C} & 7.91815 & -1.44943 & -1.96918 \\ \mathrm{C} & 6.54188 & -1.56713 & -1.80411 \\ \mathrm{C} & 10.08329 & -0.13885 & -1.84737 \\ \mathrm{~N} & 3.35140 & 1.25283 & 1.90094 \\ \mathrm{C} & 4.00805 & 1.71365 & 3.12492 \\ \mathrm{C} & 3.85434 & 3.23267 & 3.24610 \\ \mathrm{O} & 2.48530 & 3.59816 & 3.20921 \\ \mathrm{C} & 1.87707 & 3.19058 & 1.98143 \\ \mathrm{C} & 1.94964 & 1.68075 & 1.78809 \\ \mathrm{H} & 5.06382 & 0.40666 & 1.19060 \\ \mathrm{C} & 3.90491 & -2.99875 & -0.00622 \\ \mathrm{C} & 2.71425 & -3.44575 & -0.73423 \\ \mathrm{C} & 1.48386 & -3.03166 & -0.26746 \\ \mathrm{~N} & 1.42940 & -2.38187 & 0.94457 \\ \mathrm{C} & 2.48232 & -2.16216 & 1.77749 \\ \mathrm{C} & 3.75536 & -2.53189 & 1.36109 \\ \mathrm{C} & 2.12064 & -1.56909 & 3.10686 \\ \mathrm{C} & 0.14925 & -3.16456 & -0.93628 \\ \mathrm{C} & 4.95181 & -2.32617 & 2.21738 \\ \mathrm{C} & 3.01693 & -4.10741 & -2.02998 \\ \mathrm{C} & 6.29078 & -2.83796 & 1.70755 \\ \mathrm{O} & 4.90003 & -1.74845 & 3.30095 \\ \mathrm{C} & 1.94128 & -4.62012 & -2.96715 \\ \mathrm{O} & 4.19655 & -4.21960 & -2.36860 \\ \mathrm{C} & -6.17513 & 1.58957 & 0.86092 \\ \mathrm{C} & -5.41922 & 0.39559 & 0.69943\end{array}$




\begin{tabular}{|c|c|c|c|}
\hline $\mathrm{C}$ & -5.93140 & -0.81068 & 1.27334 \\
\hline $\mathrm{C}$ & -7.18669 & -0.79095 & 1.93815 \\
\hline $\mathrm{C}$ & -7.90154 & 0.37802 & 2.06160 \\
\hline $\mathrm{C}$ & -7.38103 & 1.58047 & 1.52603 \\
\hline $\mathrm{C}$ & -4.16469 & 0.35194 & 0.00273 \\
\hline $\mathrm{C}$ & -3.40978 & -0.80885 & 0.04448 \\
\hline $\mathrm{C}$ & -3.90728 & -2.01830 & 0.60990 \\
\hline $\mathrm{C}$ & -5.16723 & -1.99922 & 1.17020 \\
\hline $\mathrm{C}$ & -3.67500 & 1.52216 & -0.77050 \\
\hline $\mathrm{C}$ & -4.47327 & 2.07998 & -1.82616 \\
\hline $\mathrm{C}$ & -4.05252 & 3.30044 & -2.44061 \\
\hline $\mathrm{C}$ & -2.85584 & 3.91037 & -1.99525 \\
\hline $\mathrm{C}$ & -2.03163 & 3.32615 & -1.05478 \\
\hline $\mathrm{C}$ & -2.43820 & 2.08628 & -0.48406 \\
\hline $\mathrm{C}$ & -5.65775 & 1.45952 & -2.31309 \\
\hline $\mathrm{C}$ & -6.39284 & 2.03175 & -3.32730 \\
\hline $\mathrm{C}$ & -5.99040 & 3.25795 & -3.90901 \\
\hline $\mathrm{C}$ & -4.84072 & 3.87492 & -3.47359 \\
\hline $\mathrm{C}$ & -3.15469 & -3.30968 & 0.53138 \\
\hline $\mathrm{O}$ & -1.61845 & 1.48701 & 0.45794 \\
\hline $\mathrm{O}$ & -2.17287 & -0.81750 & -0.57407 \\
\hline $\mathrm{C}$ & -0.83046 & 4.10362 & -0.60944 \\
\hline $\mathrm{C}$ & -3.19968 & -4.06577 & -0.66116 \\
\hline $\mathrm{C}$ & -2.55307 & -5.30529 & -0.70128 \\
\hline $\mathrm{C}$ & -1.87478 & -5.82162 & 0.40548 \\
\hline $\mathrm{C}$ & -1.83876 & -5.05216 & 1.56915 \\
\hline $\mathrm{C}$ & -2.45840 & -3.79982 & 1.65908 \\
\hline $\mathrm{C}$ & 0.36430 & 4.06497 & -1.35823 \\
\hline $\mathrm{C}$ & 1.38736 & 4.96382 & -1.03181 \\
\hline $\mathrm{C}$ & 1.26978 & 5.87850 & 0.01752 \\
\hline $\mathrm{C}$ & 0.08760 & 5.87535 & 0.76166 \\
\hline $\mathrm{C}$ & -0.96766 & 5.00486 & 0.47081 \\
\hline $\mathrm{P}$ & -0.90609 & 0.01283 & 0.13190 \\
\hline $\mathrm{O}$ & 0.16718 & 0.13171 & -0.90760 \\
\hline $\mathrm{O}$ & -0.60450 & -0.61219 & 1.47685 \\
\hline $\mathrm{C}$ & -2.21506 & 5.00546 & 1.35095 \\
\hline $\mathrm{C}$ & -2.70813 & 6.41712 & 1.70889 \\
\hline $\mathrm{C}$ & -1.96730 & 4.16483 & 2.62016 \\
\hline $\mathrm{C}$ & 2.40265 & 6.84641 & 0.32768 \\
\hline $\mathrm{C}$ & 2.71890 & 6.94008 & 1.83144 \\
\hline $\mathrm{C}$ & 2.09838 & 8.24049 & -0.25393 \\
\hline $\mathrm{C}$ & 0.53014 & 3.09419 & -2.52373 \\
\hline $\mathrm{C}$ & 1.95159 & 2.52199 & -2.63163 \\
\hline $\mathrm{C}$ & 0.13086 & 3.75437 & -3.85802 \\
\hline $\mathrm{C}$ & -1.16768 & -7.16783 & 0.34701 \\
\hline $\mathrm{C}$ & 0.05182 & -7.11558 & -0.59189 \\
\hline
\end{tabular}




\begin{tabular}{|c|c|c|c|}
\hline $\mathrm{C}$ & -2.12084 & -8.30752 & -0.05319 \\
\hline $\mathrm{C}$ & -2.37139 & -2.99886 & 2.95628 \\
\hline $\mathrm{C}$ & -1.03408 & -3.19851 & 3.68945 \\
\hline $\mathrm{C}$ & -3.52917 & -3.34070 & 3.91500 \\
\hline $\mathrm{C}$ & -3.90981 & -3.55539 & -1.91202 \\
\hline $\mathrm{C}$ & -4.92351 & -4.57412 & -2.46235 \\
\hline $\mathrm{C}$ & -2.89082 & -3.13783 & -2.98947 \\
\hline $\mathrm{H}$ & 2.46148 & 0.22970 & -0.46894 \\
\hline $\mathrm{H}$ & 4.02246 & -1.68644 & -3.09612 \\
\hline $\mathrm{H}$ & 3.64507 & 0.04381 & -3.15116 \\
\hline $\mathrm{H}$ & 2.50513 & -1.06647 & -2.38177 \\
\hline $\mathrm{H}$ & 5.86068 & 1.60000 & -0.79212 \\
\hline $\mathrm{H}$ & 8.30181 & 1.79631 & -1.07281 \\
\hline $\mathrm{H}$ & 8.48754 & -2.30760 & -2.31935 \\
\hline $\mathrm{H}$ & 6.05003 & -2.51052 & -2.03017 \\
\hline $\mathrm{H}$ & 10.43550 & -0.68048 & -2.73238 \\
\hline $\mathrm{H}$ & 10.59881 & -0.56971 & -0.97873 \\
\hline $\mathrm{H}$ & 10.40626 & 0.90346 & -1.93650 \\
\hline $\mathrm{H}$ & 5.05866 & 1.41148 & 3.11286 \\
\hline $\mathrm{H}$ & 3.52682 & 1.23844 & 3.98902 \\
\hline $\mathrm{H}$ & 4.25238 & 3.58117 & 4.20409 \\
\hline $\mathrm{H}$ & 4.40933 & 3.72741 & 2.43023 \\
\hline $\mathrm{H}$ & 0.83849 & 3.51794 & 2.01584 \\
\hline $\mathrm{H}$ & 2.36732 & 3.69083 & 1.13673 \\
\hline $\mathrm{H}$ & 1.54228 & 1.41286 & 0.81455 \\
\hline $\mathrm{H}$ & 1.35685 & 1.16474 & 2.54993 \\
\hline $\mathrm{H}$ & 4.21068 & -1.88133 & -0.66834 \\
\hline $\mathrm{H}$ & 4.80268 & -3.55923 & -0.24988 \\
\hline $\mathrm{H}$ & 0.54701 & -1.87750 & 1.18367 \\
\hline $\mathrm{H}$ & 2.81138 & -0.77195 & 3.36556 \\
\hline $\mathrm{H}$ & 1.09373 & -1.20274 & 3.09490 \\
\hline $\mathrm{H}$ & 2.22771 & -2.32850 & 3.88978 \\
\hline $\mathrm{H}$ & -0.65511 & -2.96903 & -0.23011 \\
\hline $\mathrm{H}$ & 0.06153 & -2.42355 & -1.73718 \\
\hline $\mathrm{H}$ & -0.01517 & -4.15851 & -1.34415 \\
\hline $\mathrm{H}$ & 7.04056 & -2.65781 & 2.47970 \\
\hline $\mathrm{H}$ & 6.24990 & -3.91029 & 1.48152 \\
\hline $\mathrm{H}$ & 6.58816 & -2.32368 & 0.78659 \\
\hline $\mathrm{H}$ & 1.30475 & -5.36645 & -2.48312 \\
\hline $\mathrm{H}$ & 2.43890 & -5.07129 & -3.82743 \\
\hline $\mathrm{H}$ & 1.29435 & -3.80609 & -3.31015 \\
\hline $\mathrm{H}$ & -5.78594 & 2.51865 & 0.46038 \\
\hline $\mathrm{H}$ & -7.56519 & -1.71899 & 2.36056 \\
\hline $\mathrm{H}$ & -8.85730 & 0.38438 & 2.57847 \\
\hline $\mathrm{H}$ & -7.93674 & 2.50678 & 1.64443 \\
\hline $\mathrm{H}$ & -5.58695 & -2.92561 & 1.55227 \\
\hline
\end{tabular}




\begin{tabular}{|c|c|c|c|}
\hline $\mathrm{H}$ & -2.57617 & 4.87696 & -2.40568 \\
\hline $\mathrm{H}$ & -5.97535 & 0.51625 & -1.88420 \\
\hline $\mathrm{H}$ & -7.28899 & 1.53396 & -3.68799 \\
\hline $\mathrm{H}$ & -6.58372 & 3.70103 & -4.70422 \\
\hline $\mathrm{H}$ & -4.50863 & 4.80875 & -3.92141 \\
\hline $\mathrm{H}$ & -2.57867 & -5.88031 & -1.62344 \\
\hline $\mathrm{H}$ & -1.30518 & -5.44298 & 2.43102 \\
\hline $\mathrm{H}$ & 2.30903 & 4.95024 & -1.60820 \\
\hline $\mathrm{H}$ & -0.01364 & 6.56266 & 1.59549 \\
\hline $\mathrm{H}$ & -3.02101 & 4.51931 & 0.79248 \\
\hline $\mathrm{H}$ & -2.84707 & 7.02987 & 0.81110 \\
\hline $\mathrm{H}$ & -3.66786 & 6.35664 & 2.23508 \\
\hline $\mathrm{H}$ & -2.00903 & 6.94182 & 2.37043 \\
\hline $\mathrm{H}$ & -1.69482 & 3.13716 & 2.36053 \\
\hline $\mathrm{H}$ & -1.15613 & 4.59875 & 3.21877 \\
\hline $\mathrm{H}$ & -2.86846 & 4.13243 & 3.24471 \\
\hline $\mathrm{H}$ & 3.30141 & 6.46486 & -0.17763 \\
\hline $\mathrm{H}$ & 1.91255 & 7.44562 & 2.37591 \\
\hline $\mathrm{H}$ & 3.63311 & 7.52394 & 1.99200 \\
\hline $\mathrm{H}$ & 2.84743 & 5.95155 & 2.28448 \\
\hline $\mathrm{H}$ & 1.19579 & 8.65876 & 0.20795 \\
\hline $\mathrm{H}$ & 2.92782 & 8.93383 & -0.06753 \\
\hline $\mathrm{H}$ & 1.92738 & 8.18905 & -1.33488 \\
\hline $\mathrm{H}$ & -0.13364 & 2.24327 & -2.34230 \\
\hline $\mathrm{H}$ & 2.29745 & 2.12760 & -1.67367 \\
\hline $\mathrm{H}$ & 1.95929 & 1.70047 & -3.35554 \\
\hline $\mathrm{H}$ & 2.67443 & 3.27184 & -2.97691 \\
\hline $\mathrm{H}$ & -0.91408 & 4.07608 & -3.85314 \\
\hline $\mathrm{H}$ & 0.75662 & 4.63396 & -4.05556 \\
\hline $\mathrm{H}$ & 0.26282 & 3.04998 & -4.68843 \\
\hline $\mathrm{H}$ & -0.79549 & -7.38608 & 1.35732 \\
\hline $\mathrm{H}$ & 0.75441 & -6.33352 & -0.28114 \\
\hline $\mathrm{H}$ & -0.26312 & -6.90282 & -1.62120 \\
\hline $\mathrm{H}$ & 0.58676 & -8.07276 & -0.59816 \\
\hline $\mathrm{H}$ & -2.50587 & -8.16523 & -1.06978 \\
\hline $\mathrm{H}$ & -1.60289 & -9.27363 & -0.02609 \\
\hline $\mathrm{H}$ & -2.97971 & -8.35779 & 0.62458 \\
\hline $\mathrm{H}$ & -2.43454 & -1.93954 & 2.69001 \\
\hline $\mathrm{H}$ & -0.19009 & -3.15117 & 2.99881 \\
\hline $\mathrm{H}$ & -0.90267 & -2.41710 & 4.44547 \\
\hline $\mathrm{H}$ & -0.99083 & -4.16527 & 4.20638 \\
\hline $\mathrm{H}$ & -4.50281 & -3.09724 & 3.48396 \\
\hline $\mathrm{H}$ & -3.52251 & -4.41042 & 4.15934 \\
\hline $\mathrm{H}$ & -3.42659 & -2.77841 & 4.85112 \\
\hline $\mathrm{H}$ & -4.47540 & -2.65967 & -1.63908 \\
\hline $\mathrm{H}$ & -5.64718 & -4.86619 & -1.69314 \\
\hline
\end{tabular}




$\begin{array}{llll}\mathrm{H} & -5.47480 & -4.14209 & -3.30579 \\ \mathrm{H} & -4.43231 & -5.48543 & -2.82327 \\ \mathrm{H} & -2.23975 & -2.34360 & -2.61379 \\ \mathrm{H} & -2.26681 & -3.98917 & -3.29043 \\ \mathrm{H} & -3.40614 & -2.76586 & -3.88323\end{array}$

TS5-E

M06-2X/6-31G(d) Energy = -3926.923678

M06-2X/6-31G(d) Free Energy = -3925.517691

Number of Imaginary Frequencies $=1(-1011.62)$

$\begin{array}{lccc}\text { M06-2X/6-31G(d) } & \text { Geometry } & \\ \mathrm{C} & 3.84333 & 1.26554 & 1.38636 \\ \mathrm{C} & 4.52483 & 0.26155 & 0.64099 \\ \mathrm{C} & 2.46533 & 1.33128 & 1.50719 \\ \mathrm{C} & 5.99621 & 0.12903 & 0.92417 \\ \mathrm{C} & 3.83221 & -1.04405 & 0.29378 \\ \mathrm{C} & 6.90025 & -0.25271 & -0.07455 \\ \mathrm{C} & 8.24938 & -0.40677 & 0.21748 \\ \mathrm{C} & 8.74385 & -0.19500 & 1.50805 \\ \mathrm{C} & 7.83827 & 0.17399 & 2.50243 \\ \mathrm{C} & 6.48577 & 0.33759 & 2.21785 \\ \mathrm{C} & 10.21385 & -0.34524 & 1.80410 \\ \mathrm{~N} & 1.76507 & 2.28487 & 2.12542 \\ \mathrm{C} & 2.34694 & 3.41415 & 2.84373 \\ \mathrm{C} & 2.20087 & 3.15976 & 4.34282 \\ \mathrm{O} & 0.84641 & 2.95811 & 4.68046 \\ \mathrm{C} & 0.29291 & 1.85331 & 3.98959 \\ \mathrm{C} & 0.35883 & 2.06443 & 2.47779 \\ \mathrm{H} & 1.83418 & 0.55476 & 1.07220 \\ \mathrm{C} & 4.15038 & 1.33718 & -1.79900 \\ \mathrm{C} & 3.22817 & 2.35485 & -1.31697 \\ \mathrm{C} & 1.86777 & 2.13258 & -1.44355 \\ \mathrm{~N} & 1.44332 & 1.03316 & -2.11179 \\ \mathrm{C} & 2.24435 & 0.13936 & -2.75840 \\ \mathrm{C} & 3.60722 & 0.30896 & -2.69223 \\ \mathrm{C} & 1.47440 & -0.95791 & -3.44646 \\ \mathrm{C} & 0.76665 & 3.02001 & -0.94892 \\ \mathrm{C} & 4.61077 & -0.48553 & -3.44136 \\ \mathrm{C} & 3.75185 & 3.52844 & -0.57782 \\ \mathrm{C} & 4.24178 & -1.27652 & -4.67990 \\ \mathrm{O} & 5.78146 & -0.43860 & -3.09434 \\ \mathrm{C} & 5.26038 & 3.67885 & -0.49553 \\ \mathrm{O} & 3.02643 & 4.36196 & -0.05555 \\ \mathrm{C} & -6.36489 & -2.18038 & -0.81244\end{array}$




\begin{tabular}{|c|c|c|c|}
\hline $\mathrm{C}$ & -5.63741 & -0.96889 & -0.65845 \\
\hline $\mathrm{C}$ & -6.21090 & 0.23024 & -1.16544 \\
\hline $\mathrm{C}$ & -7.50260 & 0.19244 & -1.75289 \\
\hline $\mathrm{C}$ & -8.19014 & -0.98739 & -1.86495 \\
\hline $\mathrm{C}$ & -7.60497 & -2.18800 & -1.39913 \\
\hline $\mathrm{C}$ & -4.34079 & -0.91593 & -0.04675 \\
\hline $\mathrm{C}$ & -3.64488 & 0.27630 & -0.08528 \\
\hline $\mathrm{C}$ & -4.20048 & 1.48521 & -0.59220 \\
\hline $\mathrm{C}$ & -5.47826 & 1.44322 & -1.08892 \\
\hline $\mathrm{C}$ & -3.70949 & -2.10406 & 0.58911 \\
\hline $\mathrm{C}$ & -4.34454 & -2.85122 & 1.63633 \\
\hline $\mathrm{C}$ & -3.69658 & -4.01252 & 2.14577 \\
\hline $\mathrm{C}$ & -2.41045 & -4.36839 & 1.66238 \\
\hline $\mathrm{C}$ & -1.75521 & -3.60317 & 0.73174 \\
\hline $\mathrm{C}$ & -2.43996 & -2.47631 & 0.19873 \\
\hline $\mathrm{C}$ & -5.58540 & -2.46652 & 2.21373 \\
\hline $\mathrm{C}$ & -6.16523 & -3.21711 & 3.20499 \\
\hline $\mathrm{C}$ & -5.53964 & -4.39398 & 3.67883 \\
\hline $\mathrm{C}$ & -4.32942 & -4.77540 & 3.16225 \\
\hline $\mathrm{C}$ & -3.43496 & 2.76609 & -0.48601 \\
\hline $\mathrm{O}$ & -1.81351 & -1.77957 & -0.80426 \\
\hline $\mathrm{O}$ & -2.37028 & 0.33020 & 0.44023 \\
\hline $\mathrm{C}$ & -0.35286 & -3.87734 & 0.30018 \\
\hline $\mathrm{C}$ & -3.34214 & 3.39528 & 0.76811 \\
\hline $\mathrm{C}$ & -2.63307 & 4.59446 & 0.87273 \\
\hline $\mathrm{C}$ & -2.05080 & 5.20654 & -0.23392 \\
\hline $\mathrm{C}$ & -2.17663 & 4.57393 & -1.47182 \\
\hline $\mathrm{C}$ & -2.84022 & 3.35448 & -1.62135 \\
\hline $\mathrm{C}$ & 0.70415 & -3.69244 & 1.21069 \\
\hline $\mathrm{C}$ & 2.01052 & -3.93629 & 0.77989 \\
\hline $\mathrm{C}$ & 2.30282 & -4.31870 & -0.52495 \\
\hline $\mathrm{C}$ & 1.23808 & -4.49144 & -1.40999 \\
\hline $\mathrm{C}$ & -0.08430 & -4.28023 & -1.02309 \\
\hline $\mathrm{P}$ & -1.17265 & -0.30232 & -0.49554 \\
\hline $\mathrm{O}$ & 0.05713 & -0.36460 & 0.34845 \\
\hline $\mathrm{O}$ & -1.13654 & 0.38262 & -1.83624 \\
\hline $\mathrm{C}$ & -1.19169 & -4.54491 & -2.03265 \\
\hline $\mathrm{C}$ & -1.23894 & -6.03585 & -2.39221 \\
\hline $\mathrm{C}$ & -1.04683 & -3.67988 & -3.28879 \\
\hline $\mathrm{C}$ & 3.73523 & -4.56102 & -0.96090 \\
\hline $\mathrm{C}$ & 4.06801 & -3.80901 & -2.25313 \\
\hline $\mathrm{C}$ & 4.01730 & -6.05985 & -1.11822 \\
\hline $\mathrm{C}$ & 0.48635 & -3.23439 & 2.64593 \\
\hline $\mathrm{C}$ & 1.33584 & -2.00649 & 2.99236 \\
\hline $\mathrm{C}$ & 0.75942 & -4.37908 & 3.62931 \\
\hline $\mathrm{C}$ & -1.37008 & 6.55742 & -0.10202 \\
\hline
\end{tabular}




\begin{tabular}{|c|c|c|c|}
\hline $\mathrm{C}$ & -2.19178 & 7.64003 & -0.81350 \\
\hline $\mathrm{C}$ & 0.07230 & 6.55270 & -0.61739 \\
\hline $\mathrm{C}$ & -2.95665 & 2.72374 & -3.00225 \\
\hline $\mathrm{C}$ & -1.66303 & 2.80932 & -3.81753 \\
\hline $\mathrm{C}$ & -4.10256 & 3.37570 & -3.78884 \\
\hline $\mathrm{C}$ & -4.03178 & 2.84051 & 2.00652 \\
\hline $\mathrm{C}$ & -5.02718 & 3.85306 & 2.58576 \\
\hline $\mathrm{C}$ & -3.01493 & 2.40007 & 3.06193 \\
\hline $\mathrm{H}$ & 4.45790 & 2.04250 & 1.83029 \\
\hline $\mathrm{H}$ & 3.83503 & -1.69078 & 1.17761 \\
\hline $\mathrm{H}$ & 4.38729 & -1.55803 & -0.49755 \\
\hline $\mathrm{H}$ & 2.79247 & -0.91908 & -0.03009 \\
\hline $\mathrm{H}$ & 6.54795 & -0.40827 & -1.09092 \\
\hline $\mathrm{H}$ & 8.93489 & -0.69492 & -0.57590 \\
\hline $\mathrm{H}$ & 8.19347 & 0.33023 & 3.51796 \\
\hline $\mathrm{H}$ & 5.79663 & 0.60182 & 3.01469 \\
\hline $\mathrm{H}$ & 10.39725 & -0.41696 & 2.87920 \\
\hline $\mathrm{H}$ & 10.77885 & 0.51388 & 1.42597 \\
\hline $\mathrm{H}$ & 10.62363 & -1.24043 & 1.32717 \\
\hline $\mathrm{H}$ & 1.78374 & 4.31077 & 2.56236 \\
\hline $\mathrm{H}$ & 3.38315 & 3.56883 & 2.54521 \\
\hline $\mathrm{H}$ & 2.80060 & 2.27767 & 4.62218 \\
\hline $\mathrm{H}$ & 2.54684 & 4.02151 & 4.91878 \\
\hline $\mathrm{H}$ & 0.84239 & 0.93296 & 4.24583 \\
\hline $\mathrm{H}$ & -0.73942 & 1.75585 & 4.32937 \\
\hline $\mathrm{H}$ & -0.21919 & 2.95389 & 2.19466 \\
\hline $\mathrm{H}$ & -0.02051 & 1.20061 & 1.92241 \\
\hline $\mathrm{H}$ & 4.52609 & 0.75834 & -0.67068 \\
\hline $\mathrm{H}$ & 5.15399 & 1.66299 & -2.07748 \\
\hline $\mathrm{H}$ & 0.41371 & 0.82809 & -2.08199 \\
\hline $\mathrm{H}$ & 1.78218 & -1.94128 & -3.07465 \\
\hline $\mathrm{H}$ & 0.40954 & -0.83896 & -3.23551 \\
\hline $\mathrm{H}$ & 1.61269 & -0.93580 & -4.52941 \\
\hline $\mathrm{H}$ & -0.19897 & 2.51366 & -1.02228 \\
\hline $\mathrm{H}$ & 0.95406 & 3.34071 & 0.07447 \\
\hline $\mathrm{H}$ & 0.73094 & 3.93085 & -1.55626 \\
\hline $\mathrm{H}$ & 5.17082 & -1.60943 & -5.14352 \\
\hline $\mathrm{H}$ & 3.63367 & -2.15041 & -4.43524 \\
\hline $\mathrm{H}$ & 3.67704 & -0.65879 & -5.38461 \\
\hline $\mathrm{H}$ & 5.48580 & 4.51802 & 0.16323 \\
\hline $\mathrm{H}$ & 5.67084 & 3.88667 & -1.49081 \\
\hline $\mathrm{H}$ & 5.75071 & 2.77198 & -0.12481 \\
\hline $\mathrm{H}$ & -5.92168 & -3.10882 & -0.46892 \\
\hline $\mathrm{H}$ & -7.92864 & 1.12098 & -2.12410 \\
\hline $\mathrm{H}$ & -9.17474 & -1.00715 & -2.32142 \\
\hline $\mathrm{H}$ & -8.14021 & -3.12563 & -1.51261 \\
\hline
\end{tabular}




\begin{tabular}{|c|c|c|c|}
\hline $\mathrm{H}$ & -5.94747 & 2.36049 & -1.43565 \\
\hline $\mathrm{H}$ & -1.92129 & -5.24973 & 2.07148 \\
\hline $\mathrm{H}$ & -6.07043 & -1.56074 & 1.86645 \\
\hline $\mathrm{H}$ & -7.11092 & -2.90143 & 3.63458 \\
\hline $\mathrm{H}$ & -6.01296 & -4.98168 & 4.45905 \\
\hline $\mathrm{H}$ & -3.82398 & -5.66446 & 3.53057 \\
\hline $\mathrm{H}$ & -2.55850 & 5.08503 & 1.84238 \\
\hline $\mathrm{H}$ & -1.73981 & 5.04453 & -2.35066 \\
\hline $\mathrm{H}$ & 2.83174 & -3.81357 & 1.48426 \\
\hline $\mathrm{H}$ & 1.43961 & -4.81391 & -2.43058 \\
\hline $\mathrm{H}$ & -2.14994 & -4.29013 & -1.57083 \\
\hline $\mathrm{H}$ & -1.36923 & -6.65173 & -1.49704 \\
\hline $\mathrm{H}$ & -2.06951 & -6.23956 & -3.07603 \\
\hline $\mathrm{H}$ & -0.31219 & -6.35089 & -2.88487 \\
\hline $\mathrm{H}$ & -1.09013 & -2.61923 & -3.02844 \\
\hline $\mathrm{H}$ & -0.10056 & -3.88205 & -3.80532 \\
\hline $\mathrm{H}$ & -1.85905 & -3.89450 & -3.99128 \\
\hline $\mathrm{H}$ & 4.38805 & -4.17239 & -0.16779 \\
\hline $\mathrm{H}$ & 3.78239 & -2.75493 & -2.16863 \\
\hline $\mathrm{H}$ & 5.13893 & -3.85651 & -2.47796 \\
\hline $\mathrm{H}$ & 3.52859 & -4.23791 & -3.10634 \\
\hline $\mathrm{H}$ & 3.82148 & -6.59517 & -0.18480 \\
\hline $\mathrm{H}$ & 3.37270 & -6.48956 & -1.89324 \\
\hline $\mathrm{H}$ & 5.05925 & -6.23369 & -1.40706 \\
\hline $\mathrm{H}$ & -0.55936 & -2.93583 & 2.75496 \\
\hline $\mathrm{H}$ & 1.14047 & -1.20843 & 2.27053 \\
\hline $\mathrm{H}$ & 1.08309 & -1.65241 & 3.99845 \\
\hline $\mathrm{H}$ & 2.40739 & -2.23789 & 2.98895 \\
\hline $\mathrm{H}$ & 0.12469 & -5.24615 & 3.42112 \\
\hline $\mathrm{H}$ & 1.80285 & -4.70774 & 3.56078 \\
\hline $\mathrm{H}$ & 0.57371 & -4.05628 & 4.65920 \\
\hline $\mathrm{H}$ & -1.34413 & 6.80420 & 0.96745 \\
\hline $\mathrm{H}$ & -3.21719 & 7.66932 & -0.43373 \\
\hline $\mathrm{H}$ & -2.23794 & 7.44149 & -1.89014 \\
\hline $\mathrm{H}$ & -1.73927 & 8.62709 & -0.67156 \\
\hline $\mathrm{H}$ & 0.10400 & 6.31614 & -1.68767 \\
\hline $\mathrm{H}$ & 0.52519 & 7.54136 & -0.48802 \\
\hline $\mathrm{H}$ & 0.69534 & 5.82224 & -0.09293 \\
\hline $\mathrm{H}$ & -3.17773 & 1.66146 & -2.86499 \\
\hline $\mathrm{H}$ & -0.82214 & 2.38497 & -3.26542 \\
\hline $\mathrm{H}$ & -1.77804 & 2.24034 & -4.74587 \\
\hline $\mathrm{H}$ & -1.42080 & 3.84128 & -4.09613 \\
\hline $\mathrm{H}$ & -5.05949 & 3.27587 & -3.26953 \\
\hline $\mathrm{H}$ & -3.90823 & 4.44562 & -3.92878 \\
\hline $\mathrm{H}$ & -4.20161 & 2.91539 & -4.77773 \\
\hline $\mathrm{H}$ & -4.60400 & 1.95489 & 1.71598 \\
\hline
\end{tabular}




$\begin{array}{llll}\mathrm{H} & -5.75675 & 4.16146 & 1.83081 \\ \mathrm{H} & -5.56844 & 3.41351 & 3.42996 \\ \mathrm{H} & -4.51694 & 4.75182 & 2.94837 \\ \mathrm{H} & -2.36387 & 1.62323 & 2.65011 \\ \mathrm{H} & -2.39632 & 3.24557 & 3.38881 \\ \mathrm{H} & -3.52345 & 1.99598 & 3.94437\end{array}$

TS5-Z

M06-2X/6-31G(d) Energy = -3926.922624

M06-2X/6-31G(d) Free Energy = -3925.513752

Number of Imaginary Frequencies $=1(-978.27)$

$\begin{array}{lccc}\text { M06-2X/6-31G(d) } & \text { Geometry } & \\ \mathrm{C} & -1.92008 & -3.23287 & 2.72778 \\ \mathrm{C} & -3.01254 & -3.71116 & 1.92987 \\ \mathrm{C} & -1.32494 & -1.98958 & 2.62596 \\ \mathrm{~N} & -0.36429 & -1.47923 & 3.41005 \\ \mathrm{C} & 0.11902 & -2.10623 & 4.63491 \\ \mathrm{C} & 1.60770 & -1.81079 & 4.82317 \\ \mathrm{O} & 1.89781 & -0.43638 & 4.73992 \\ \mathrm{C} & 1.49569 & 0.09438 & 3.48699 \\ \mathrm{C} & -0.00359 & -0.05870 & 3.29846 \\ \mathrm{H} & -1.62203 & -1.30024 & 1.84468 \\ \mathrm{C} & -1.63828 & -4.85110 & -0.11429 \\ \mathrm{C} & -0.33564 & -4.39911 & 0.36463 \\ \mathrm{C} & 0.25956 & -3.31554 & -0.24327 \\ \mathrm{~N} & -0.30885 & -2.80007 & -1.36910 \\ \mathrm{C} & -1.42456 & -3.28848 & -1.98333 \\ \mathrm{C} & -2.09020 & -4.34652 & -1.40906 \\ \mathrm{C} & -1.81166 & -2.55382 & -3.23233 \\ \mathrm{C} & 1.49534 & -2.59023 & 0.18857 \\ \mathrm{C} & -3.30776 & -4.89831 & -2.05538 \\ \mathrm{C} & 0.11662 & -5.09229 & 1.59477 \\ \mathrm{C} & -4.22273 & -5.75560 & -1.20523 \\ \mathrm{O} & -3.59271 & -4.65287 & -3.21364 \\ \mathrm{C} & 1.36921 & -4.68812 & 2.34267 \\ \mathrm{O} & -0.56881 & -6.00456 & 2.03680 \\ \mathrm{C} & 2.63541 & 4.39537 & 2.41210 \\ \mathrm{C} & 1.42010 & 4.13873 & 1.71960 \\ \mathrm{C} & 0.22578 & 4.73977 & 2.20295 \\ \mathrm{C} & 0.28513 & 5.60379 & 3.32842 \\ \mathrm{C} & 1.47301 & 5.84265 & 3.96790 \\ \mathrm{C} & 2.65829 & 5.22073 & 3.50773 \\ \mathrm{C} & 1.34901 & 3.28079 & 0.57477 \\ \mathrm{C} & 0.10804 & 2.93992 & 0.07207 \\ \mathrm{C} & -1.09449 & 3.55602 & 0.52009\end{array}$




\begin{tabular}{|c|c|c|c|}
\hline $\mathrm{C}$ & -1.00083 & 4.46030 & 1.55151 \\
\hline $\mathrm{C}$ & 2.57041 & 2.76925 & -0.09668 \\
\hline $\mathrm{C}$ & 3.57412 & 3.66356 & -0.59786 \\
\hline $\mathrm{C}$ & 4.75104 & 3.11751 & -1.17876 \\
\hline $\mathrm{C}$ & 4.88213 & 1.70999 & -1.28597 \\
\hline $\mathrm{C}$ & 3.88737 & 0.85169 & -0.88841 \\
\hline $\mathrm{C}$ & 2.71902 & 1.41266 & -0.29767 \\
\hline $\mathrm{C}$ & 3.43394 & 5.07845 & -0.56983 \\
\hline $\mathrm{C}$ & 4.42492 & 5.89352 & -1.05534 \\
\hline $\mathrm{C}$ & 5.61179 & 5.34609 & -1.59645 \\
\hline $\mathrm{C}$ & 5.76494 & 3.98628 & -1.66028 \\
\hline $\mathrm{C}$ & -2.41840 & 3.29524 & -0.12039 \\
\hline $\mathrm{O}$ & 1.73899 & 0.56214 & 0.16403 \\
\hline $\mathrm{O}$ & 0.03133 & 2.04964 & -0.97417 \\
\hline $\mathrm{C}$ & 4.07167 & -0.62499 & -1.03808 \\
\hline $\mathrm{C}$ & -3.48515 & 2.78954 & 0.65291 \\
\hline $\mathrm{C}$ & -4.75365 & 2.70305 & 0.07691 \\
\hline $\mathrm{C}$ & -5.00732 & 3.11984 & -1.22919 \\
\hline $\mathrm{C}$ & -3.92896 & 3.56740 & -1.98786 \\
\hline $\mathrm{C}$ & -2.63848 & 3.66301 & -1.46331 \\
\hline $\mathrm{C}$ & 3.80601 & -1.25157 & -2.27214 \\
\hline $\mathrm{C}$ & 4.04780 & -2.62170 & -2.38878 \\
\hline $\mathrm{C}$ & 4.55621 & -3.37804 & -1.33309 \\
\hline $\mathrm{C}$ & 4.81202 & -2.73366 & -0.12562 \\
\hline $\mathrm{C}$ & 4.55373 & -1.37255 & 0.05133 \\
\hline $\mathrm{P}$ & 0.30606 & 0.45806 & -0.67099 \\
\hline $\mathrm{O}$ & 0.52994 & -0.20537 & -1.99612 \\
\hline $\mathrm{O}$ & -0.67996 & -0.10752 & 0.29888 \\
\hline $\mathrm{C}$ & 4.78705 & -0.72272 & 1.40693 \\
\hline $\mathrm{C}$ & 6.21423 & -0.17038 & 1.51514 \\
\hline $\mathrm{C}$ & 4.49675 & -1.67277 & 2.57444 \\
\hline $\mathrm{C}$ & 4.75767 & -4.87494 & -1.47413 \\
\hline $\mathrm{C}$ & 5.69098 & -5.22427 & -2.63773 \\
\hline $\mathrm{C}$ & 3.40793 & -5.58820 & -1.62929 \\
\hline $\mathrm{C}$ & 3.27478 & -0.47353 & -3.46665 \\
\hline $\mathrm{C}$ & 2.27323 & -1.27802 & -4.30134 \\
\hline $\mathrm{C}$ & 4.43078 & -0.00043 & -4.35901 \\
\hline $\mathrm{C}$ & -6.43511 & 3.18198 & -1.74310 \\
\hline $\mathrm{C}$ & -6.56712 & 2.94020 & -3.24827 \\
\hline $\mathrm{C}$ & -7.05158 & 4.53831 & -1.36998 \\
\hline $\mathrm{C}$ & -1.54758 & 4.22662 & -2.36356 \\
\hline $\mathrm{C}$ & -1.88310 & 5.65695 & -2.80637 \\
\hline $\mathrm{C}$ & -1.30372 & 3.31744 & -3.57370 \\
\hline $\mathrm{C}$ & -3.30922 & 2.30384 & 2.08624 \\
\hline $\mathrm{C}$ & -3.51663 & 0.78909 & 2.15651 \\
\hline $\mathrm{C}$ & -4.22480 & 3.04622 & 3.06476 \\
\hline
\end{tabular}




\begin{tabular}{|c|c|c|c|}
\hline $\mathrm{H}$ & -1.57358 & -3.92776 & 3.48698 \\
\hline $\mathrm{H}$ & -0.03338 & -3.18648 & 4.59050 \\
\hline $\mathrm{H}$ & -0.45169 & -1.70698 & 5.48516 \\
\hline $\mathrm{H}$ & 1.92579 & -2.14535 & 5.81386 \\
\hline $\mathrm{H}$ & 2.18570 & -2.36154 & 4.06704 \\
\hline $\mathrm{H}$ & 1.77416 & 1.15113 & 3.48023 \\
\hline $\mathrm{H}$ & 2.02418 & -0.41303 & 2.66516 \\
\hline $\mathrm{H}$ & -0.30848 & 0.30395 & 2.31362 \\
\hline $\mathrm{H}$ & -0.52768 & 0.49872 & 4.08826 \\
\hline $\mathrm{H}$ & -2.40296 & -4.38624 & 0.82097 \\
\hline $\mathrm{H}$ & -1.83758 & -5.90110 & 0.10570 \\
\hline $\mathrm{H}$ & 0.08325 & -1.90805 & -1.72945 \\
\hline $\mathrm{H}$ & -1.60841 & -3.16643 & -4.11434 \\
\hline $\mathrm{H}$ & -2.88468 & -2.35382 & -3.23509 \\
\hline $\mathrm{H}$ & -1.25315 & -1.61557 & -3.29704 \\
\hline $\mathrm{H}$ & 1.26937 & -1.95086 & 1.05180 \\
\hline $\mathrm{H}$ & 2.30322 & -3.27079 & 0.44709 \\
\hline $\mathrm{H}$ & 1.85342 & -1.94465 & -0.61432 \\
\hline $\mathrm{H}$ & -3.69982 & -6.61404 & -0.77250 \\
\hline $\mathrm{H}$ & -4.61656 & -5.15034 & -0.38016 \\
\hline $\mathrm{H}$ & -5.04745 & -6.10375 & -1.82695 \\
\hline $\mathrm{H}$ & 2.27421 & -4.91313 & 1.76780 \\
\hline $\mathrm{H}$ & 1.39303 & -5.25396 & 3.27563 \\
\hline $\mathrm{H}$ & 1.36726 & -3.61463 & 2.55090 \\
\hline $\mathrm{H}$ & 3.54837 & 3.91982 & 2.06863 \\
\hline $\mathrm{H}$ & -0.63625 & 6.06279 & 3.67745 \\
\hline $\mathrm{H}$ & 1.50818 & 6.49900 & 4.83167 \\
\hline $\mathrm{H}$ & 3.59390 & 5.39680 & 4.02928 \\
\hline $\mathrm{H}$ & -1.90318 & 4.96210 & 1.89516 \\
\hline $\mathrm{H}$ & 5.79690 & 1.29982 & -1.70818 \\
\hline $\mathrm{H}$ & 2.52441 & 5.51359 & -0.17085 \\
\hline $\mathrm{H}$ & 4.29380 & 6.97086 & -1.03055 \\
\hline $\mathrm{H}$ & 6.38910 & 6.00421 & -1.97162 \\
\hline $\mathrm{H}$ & 6.66050 & 3.54689 & -2.09207 \\
\hline $\mathrm{H}$ & -5.58110 & 2.31604 & 0.67137 \\
\hline $\mathrm{H}$ & -4.09463 & 3.88343 & -3.01483 \\
\hline $\mathrm{H}$ & 3.82498 & -3.11418 & -3.33232 \\
\hline $\mathrm{H}$ & 5.19151 & -3.31985 & 0.70920 \\
\hline $\mathrm{H}$ & 4.09227 & 0.12148 & 1.49110 \\
\hline $\mathrm{H}$ & 6.40791 & 0.58039 & 0.74393 \\
\hline $\mathrm{H}$ & 6.37634 & 0.29206 & 2.49457 \\
\hline $\mathrm{H}$ & 6.94153 & -0.98113 & 1.39410 \\
\hline $\mathrm{H}$ & 3.57898 & -2.24484 & 2.39369 \\
\hline $\mathrm{H}$ & 5.31175 & -2.38957 & 2.72468 \\
\hline $\mathrm{H}$ & 4.37135 & -1.10897 & 3.50547 \\
\hline $\mathrm{H}$ & 5.22534 & -5.23207 & -0.54712 \\
\hline
\end{tabular}




\begin{tabular}{|c|c|c|c|}
\hline $\mathrm{H}$ & 6.65632 & -4.72102 & -2.53299 \\
\hline $\mathrm{H}$ & 5.86546 & -6.30422 & -2.68048 \\
\hline $\mathrm{H}$ & 5.25458 & -4.91964 & -3.59492 \\
\hline $\mathrm{H}$ & 2.74345 & -5.37835 & -0.78330 \\
\hline $\mathrm{H}$ & 2.89742 & -5.25413 & -2.53943 \\
\hline $\mathrm{H}$ & 3.54430 & -6.67259 & -1.69596 \\
\hline $\mathrm{H}$ & 2.74209 & 0.40156 & -3.08357 \\
\hline $\mathrm{H}$ & 1.52201 & -1.75155 & -3.66496 \\
\hline $\mathrm{H}$ & 1.75339 & -0.60962 & -4.99401 \\
\hline $\mathrm{H}$ & 2.77077 & -2.05059 & -4.89915 \\
\hline $\mathrm{H}$ & 5.11384 & 0.66245 & -3.82097 \\
\hline $\mathrm{H}$ & 5.00709 & -0.85888 & -4.72340 \\
\hline $\mathrm{H}$ & 4.04371 & 0.54326 & -5.22725 \\
\hline $\mathrm{H}$ & -7.00594 & 2.40404 & -1.21983 \\
\hline $\mathrm{H}$ & -6.06013 & 2.02271 & -3.56274 \\
\hline $\mathrm{H}$ & -6.14200 & 3.77165 & -3.82054 \\
\hline $\mathrm{H}$ & -7.62284 & 2.86185 & -3.52595 \\
\hline $\mathrm{H}$ & -6.49635 & 5.34978 & -1.85336 \\
\hline $\mathrm{H}$ & -8.09587 & 4.59529 & -1.69553 \\
\hline $\mathrm{H}$ & -7.01443 & 4.70313 & -0.28913 \\
\hline $\mathrm{H}$ & -0.61361 & 4.28025 & -1.79969 \\
\hline $\mathrm{H}$ & -2.04920 & 6.30786 & -1.94227 \\
\hline $\mathrm{H}$ & -1.06111 & 6.07236 & -3.39852 \\
\hline $\mathrm{H}$ & -2.78590 & 5.68263 & -3.42614 \\
\hline $\mathrm{H}$ & -1.02306 & 2.31038 & -3.25466 \\
\hline $\mathrm{H}$ & -2.20031 & 3.25067 & -4.20080 \\
\hline $\mathrm{H}$ & -0.49414 & 3.72064 & -4.19118 \\
\hline $\mathrm{H}$ & -2.27662 & 2.49323 & 2.39010 \\
\hline $\mathrm{H}$ & -2.83368 & 0.30770 & 1.45307 \\
\hline $\mathrm{H}$ & -3.31737 & 0.41498 & 3.16914 \\
\hline $\mathrm{H}$ & -4.53890 & 0.50055 & 1.88262 \\
\hline $\mathrm{H}$ & -4.06421 & 4.12853 & 3.02123 \\
\hline $\mathrm{H}$ & -5.28079 & 2.85744 & 2.84384 \\
\hline $\mathrm{H}$ & -4.03606 & 2.71201 & 4.09043 \\
\hline $\mathrm{C}$ & -5.43227 & -1.19005 & -0.61860 \\
\hline $\mathrm{C}$ & -6.01964 & -2.05795 & 0.30783 \\
\hline $\mathrm{C}$ & -5.24370 & -2.85630 & 1.13839 \\
\hline $\mathrm{C}$ & -3.84254 & -2.80743 & 1.07878 \\
\hline $\mathrm{C}$ & -3.25814 & -1.93635 & 0.14983 \\
\hline $\mathrm{C}$ & -4.04009 & -1.13104 & -0.67070 \\
\hline $\mathrm{C}$ & -6.27079 & -0.35896 & -1.55037 \\
\hline $\mathrm{H}$ & -7.10335 & -2.10832 & 0.37915 \\
\hline $\mathrm{H}$ & -5.73564 & -3.51244 & 1.84997 \\
\hline $\mathrm{H}$ & -2.17997 & -1.84707 & 0.06813 \\
\hline $\mathrm{H}$ & -3.54912 & -0.43329 & -1.34634 \\
\hline $\mathrm{H}$ & -5.72183 & 0.53300 & -1.86220 \\
\hline
\end{tabular}




$\begin{array}{llll}\mathrm{H} & -6.53228 & -0.92648 & -2.45093 \\ \mathrm{H} & -7.20557 & -0.04424 & -1.07608 \\ \mathrm{C} & -3.71285 & -4.91620 & 2.53866 \\ \mathrm{H} & -4.32489 & -4.60342 & 3.39306 \\ \mathrm{H} & -4.36345 & -5.41700 & 1.81785 \\ \mathrm{H} & -2.96727 & -5.63351 & 2.88884\end{array}$

\section{TS6-E}

M06-2X/6-31G(d) Energy = -3926.925080

M06-2X/6-31G(d) Free Energy $=-3925.517426$

Number of Imaginary Frequencies $=1(-906.44)$

$\begin{array}{lrrr}\text { M06-2X/6-31G(d) } & \text { Geometry } & \\ \mathrm{C} & 3.18197 & 0.58778 & 1.89780 \\ \mathrm{C} & 4.39495 & 0.45478 & 1.13765 \\ \mathrm{C} & 3.16773 & 1.00517 & 3.20648 \\ \mathrm{C} & 4.34478 & -0.39775 & -0.09224 \\ \mathrm{C} & 5.73063 & 0.58718 & 1.85084 \\ \mathrm{C} & 3.14796 & -0.99195 & -0.52265 \\ \mathrm{C} & 3.07349 & -1.66012 & -1.73929 \\ \mathrm{C} & 4.18825 & -1.78464 & -2.57027 \\ \mathrm{C} & 5.38969 & -1.21682 & -2.13449 \\ \mathrm{C} & 5.46669 & -0.52958 & -0.92733 \\ \mathrm{C} & 4.08887 & -2.47411 & -3.90625 \\ \mathrm{~N} & 2.10666 & 1.12474 & 4.02242 \\ \mathrm{C} & 2.24473 & 1.68597 & 5.36142 \\ \mathrm{C} & 1.46288 & 0.83206 & 6.35487 \\ \mathrm{O} & 0.11053 & 0.74384 & 5.97095 \\ \mathrm{C} & -0.01364 & 0.11484 & 4.70937 \\ \mathrm{C} & 0.71752 & 0.89907 & 3.62566 \\ \mathrm{H} & 4.10227 & 1.27261 & 3.69333 \\ \mathrm{C} & 4.18116 & 2.76797 & -0.18816 \\ \mathrm{C} & 2.97439 & 3.21210 & 0.50239 \\ \mathrm{C} & 1.75957 & 2.83036 & -0.02220 \\ \mathrm{~N} & 1.74393 & 2.17696 & -1.21883 \\ \mathrm{C} & 2.82403 & 1.96244 & -2.02796 \\ \mathrm{C} & 4.06247 & 2.35376 & -1.58153 \\ \mathrm{C} & 2.46220 & 1.29931 & -3.32886 \\ \mathrm{C} & 0.39144 & 2.97524 & 0.57957 \\ \mathrm{C} & 5.34765 & 2.26174 & -2.32064 \\ \mathrm{C} & 3.22509 & 3.79719 & 1.84076 \\ \mathrm{C} & 5.39469 & 2.04691 & -3.81929 \\ \mathrm{O} & 6.39180 & 2.38585 & -1.70141 \\ \mathrm{C} & 2.12098 & 4.39491 & 2.68923 \\ \mathrm{O} & 4.36618 & 3.78513 & 2.28112 \\ \mathrm{C} & -5.86564 & -2.14171 & -1.25970\end{array}$




\begin{tabular}{|c|c|c|c|}
\hline $\mathrm{C}$ & -5.18529 & -0.91438 & -1.03065 \\
\hline $\mathrm{C}$ & -5.76903 & 0.28132 & -1.53481 \\
\hline $\mathrm{C}$ & -7.02621 & 0.22359 & -2.19152 \\
\hline $\mathrm{C}$ & -7.67008 & -0.97189 & -2.37362 \\
\hline $\mathrm{C}$ & -7.07209 & -2.16791 & -1.91224 \\
\hline $\mathrm{C}$ & -3.92932 & -0.83793 & -0.34059 \\
\hline $\mathrm{C}$ & -3.27077 & 0.37481 & -0.30696 \\
\hline $\mathrm{C}$ & -3.82202 & 1.57309 & -0.84029 \\
\hline $\mathrm{C}$ & -5.07198 & 1.50988 & -1.40150 \\
\hline $\mathrm{C}$ & -3.30227 & -2.03097 & 0.29060 \\
\hline $\mathrm{C}$ & -3.98957 & -2.83391 & 1.26010 \\
\hline $\mathrm{C}$ & -3.37087 & -4.02547 & 1.73155 \\
\hline $\mathrm{C}$ & -2.07809 & -4.37372 & 1.26366 \\
\hline $\mathrm{C}$ & -1.37287 & -3.56286 & 0.40954 \\
\hline $\mathrm{C}$ & -2.00841 & -2.37482 & -0.04859 \\
\hline $\mathrm{C}$ & -5.25571 & -2.47512 & 1.79800 \\
\hline $\mathrm{C}$ & -5.88122 & -3.27397 & 2.72135 \\
\hline $\mathrm{C}$ & -5.28030 & -4.47743 & 3.15985 \\
\hline $\mathrm{C}$ & -4.05034 & -4.83864 & 2.67653 \\
\hline $\mathrm{C}$ & -3.07219 & 2.86505 & -0.75811 \\
\hline $\mathrm{O}$ & -1.31494 & -1.58914 & -0.93770 \\
\hline $\mathrm{O}$ & -2.05744 & & 0.33242 \\
\hline $\mathrm{C}$ & 0.00412 & -3.92971 & -0.04102 \\
\hline $\mathrm{C}$ & -3.03657 & 3.58093 & 0.45073 \\
\hline $\mathrm{C}$ & -2.38274 & 4.81610 & 0.48655 \\
\hline $\mathrm{C}$ & -1.74949 & 5.34758 & -0.63190 \\
\hline $\mathrm{C}$ & -1.77855 & 4.60809 & -1.81482 \\
\hline $\mathrm{C}$ & -2.41823 & 3.37112 & -1.90199 \\
\hline $\mathrm{C}$ & 1.05893 & -3.99071 & 0.88971 \\
\hline $\mathrm{C}$ & 2.32048 & -4.41079 & 0.45918 \\
\hline $\mathrm{C}$ & 2.57466 & -4.76005 & -0.86131 \\
\hline $\mathrm{C}$ & 1.51508 & -4.69400 & -1.76501 \\
\hline $\mathrm{C}$ & 0.23947 & -4.27490 & -1.38948 \\
\hline$P$ & -0.72448 & -0.14919 & -0.41859 \\
\hline $\mathrm{O}$ & 0.29030 & -0.30479 & 0.66703 \\
\hline $\mathrm{O}$ & -0.42573 & 0.62123 & -1.67311 \\
\hline $\mathrm{C}$ & -0.84498 & -4.22437 & -2.45579 \\
\hline $\mathrm{C}$ & -1.11562 & -5.62068 & -3.02985 \\
\hline $\mathrm{C}$ & -0.48378 & -3.23109 & -3.56706 \\
\hline $\mathrm{C}$ & 3.94753 & -5.20151 & -1.33275 \\
\hline $\mathrm{C}$ & 4.03515 & -6.73365 & -1.35493 \\
\hline $\mathrm{C}$ & 5.09166 & -4.60740 & -0.50842 \\
\hline $\mathrm{C}$ & 0.90312 & -3.61000 & 2.35631 \\
\hline $\mathrm{C}$ & 1.89986 & -2.51365 & 2.74644 \\
\hline $\mathrm{C}$ & 1.05509 & -4.83905 & 3.26079 \\
\hline $\mathrm{C}$ & -1.01927 & 6.67557 & -0.56323 \\
\hline
\end{tabular}




\begin{tabular}{|c|c|c|c|}
\hline $\mathrm{C}$ & -1.68504 & 7.72223 & -1.46395 \\
\hline $\mathrm{C}$ & 0.46425 & 6.52294 & -0.92203 \\
\hline $\mathrm{C}$ & -2.38883 & 2.60199 & -3.21501 \\
\hline $\mathrm{C}$ & -1.04328 & 2.72970 & -3.93773 \\
\hline $\mathrm{C}$ & -3.51802 & 3.05866 & -4.14862 \\
\hline $\mathrm{C}$ & -3.65447 & 3.04097 & 1.73144 \\
\hline $\mathrm{C}$ & -4.66535 & 4.02211 & 2.33510 \\
\hline $\mathrm{C}$ & -2.55881 & 2.68065 & 2.74434 \\
\hline $\mathrm{H}$ & 2.23866 & 0.37520 & 1.40729 \\
\hline $\mathrm{H}$ & 6.54765 & 0.72208 & 1.14231 \\
\hline $\mathrm{H}$ & 5.93045 & -0.31241 & 2.44400 \\
\hline $\mathrm{H}$ & 5.73672 & 1.46374 & 2.50115 \\
\hline $\mathrm{H}$ & 2.24011 & -0.93943 & 0.06749 \\
\hline $\mathrm{H}$ & 2.12206 & -2.09538 & -2.03611 \\
\hline $\mathrm{H}$ & 6.28069 & -1.30173 & -2.75321 \\
\hline $\mathrm{H}$ & 6.40893 & -0.06168 & -0.66572 \\
\hline $\mathrm{H}$ & 4.96469 & -3.10195 & -4.09801 \\
\hline $\mathrm{H}$ & 3.19405 & -3.10170 & -3.95409 \\
\hline $\mathrm{H}$ & 4.02439 & -1.74498 & -4.72356 \\
\hline $\mathrm{H}$ & 1.83781 & 2.70725 & 5.37179 \\
\hline $\mathrm{H}$ & 3.30396 & 1.72892 & 5.62757 \\
\hline $\mathrm{H}$ & 1.91291 & -0.17232 & 6.40762 \\
\hline $\mathrm{H}$ & 1.48612 & 1.28592 & 7.34856 \\
\hline $\mathrm{H}$ & 0.37875 & -0.91105 & 4.76074 \\
\hline $\mathrm{H}$ & -1.07958 & 0.07422 & 4.47507 \\
\hline $\mathrm{H}$ & 0.22230 & 1.87646 & 3.52240 \\
\hline $\mathrm{H}$ & 0.65752 & 0.37398 & 2.66844 \\
\hline $\mathrm{H}$ & 4.46287 & 1.68971 & 0.44479 \\
\hline $\mathrm{H}$ & 5.09194 & 3.31127 & 0.06126 \\
\hline $\mathrm{H}$ & 0.85226 & 1.70086 & -1.47785 \\
\hline $\mathrm{H}$ & 3.23973 & 0.60904 & -3.65192 \\
\hline $\mathrm{H}$ & 1.53271 & 0.73662 & -3.19566 \\
\hline $\mathrm{H}$ & 2.29732 & 2.04548 & -4.11446 \\
\hline $\mathrm{H}$ & 0.23699 & 2.18401 & 1.32014 \\
\hline $\mathrm{H}$ & 0.23595 & 3.94389 & 1.04974 \\
\hline $\mathrm{H}$ & -0.37366 & 2.85175 & -0.19142 \\
\hline $\mathrm{H}$ & 6.36697 & 2.39336 & -4.17204 \\
\hline $\mathrm{H}$ & 5.31185 & 0.97579 & -4.03690 \\
\hline $\mathrm{H}$ & 4.59432 & 2.56846 & -4.34796 \\
\hline $\mathrm{H}$ & 1.39183 & 3.63061 & 2.97536 \\
\hline $\mathrm{H}$ & 1.58415 & 5.18609 & 2.15633 \\
\hline $\mathrm{H}$ & 2.58425 & 4.80927 & 3.58581 \\
\hline $\mathrm{H}$ & -5.41337 & -3.06744 & -0.92132 \\
\hline $\mathrm{H}$ & -7.45966 & 1.14995 & -2.55974 \\
\hline $\mathrm{H}$ & -8.62810 & -1.00736 & -2.88262 \\
\hline $\mathrm{H}$ & -7.57025 & -3.11739 & -2.08196 \\
\hline
\end{tabular}




\begin{tabular}{|c|c|c|c|}
\hline $\mathrm{H}$ & -5.53908 & 2.42020 & -1.76913 \\
\hline $\mathrm{H}$ & -1.62686 & -5.30081 & 1.61054 \\
\hline $\mathrm{H}$ & -5.72191 & -1.54985 & 1.47698 \\
\hline $\mathrm{H}$ & -6.84469 & -2.97720 & 3.12406 \\
\hline $\mathrm{H}$ & -5.78979 & -5.10299 & 3.88599 \\
\hline $\mathrm{H}$ & -3.56586 & -5.75046 & 3.01624 \\
\hline $\mathrm{H}$ & -2.35003 & 5.37289 & 1.42219 \\
\hline $\mathrm{H}$ & -1.27515 & 5.00075 & -2.69542 \\
\hline $\mathrm{H}$ & 3.13130 & -4.44434 & 1.18160 \\
\hline $\mathrm{H}$ & 1.69919 & -4.96500 & -2.80491 \\
\hline $\mathrm{H}$ & -1.77430 & -3.87766 & -1.99633 \\
\hline $\mathrm{H}$ & -1.39476 & -6.32338 & -2.23872 \\
\hline $\mathrm{H}$ & -1.93037 & -5.58177 & -3.76033 \\
\hline $\mathrm{H}$ & -0.23008 & -6.01938 & -3.53693 \\
\hline $\mathrm{H}$ & -1.29193 & -3.17588 & -4.30409 \\
\hline $\mathrm{H}$ & 0.42481 & -3.54580 & -4.09496 \\
\hline $\mathrm{H}$ & -0.32580 & -2.22929 & -3.15704 \\
\hline $\mathrm{H}$ & 4.05834 & -4.84430 & -2.36609 \\
\hline $\mathrm{H}$ & 3.25321 & -7.16623 & -1.98642 \\
\hline $\mathrm{H}$ & 5.00870 & -7.06463 & -1.73222 \\
\hline $\mathrm{H}$ & 3.90702 & -7.13140 & -0.34205 \\
\hline $\mathrm{H}$ & 4.97609 & -3.52552 & -0.38366 \\
\hline $\mathrm{H}$ & 5.13980 & -5.06532 & 0.48614 \\
\hline $\mathrm{H}$ & 6.05036 & -4.79927 & -1.00087 \\
\hline $\mathrm{H}$ & -0.09972 & -3.19851 & 2.50386 \\
\hline $\mathrm{H}$ & 1.69401 & -1.61165 & 2.16718 \\
\hline $\mathrm{H}$ & 1.81769 & -2.27765 & 3.81424 \\
\hline $\mathrm{H}$ & 2.93742 & -2.80993 & 2.55712 \\
\hline $\mathrm{H}$ & 2.05918 & -5.26824 & 3.16902 \\
\hline $\mathrm{H}$ & 0.33562 & -5.62143 & 2.99936 \\
\hline $\mathrm{H}$ & 0.89965 & -4.56688 & 4.31026 \\
\hline $\mathrm{H}$ & -1.08279 & 7.03145 & 0.47373 \\
\hline $\mathrm{H}$ & -2.73775 & 7.85586 & -1.19922 \\
\hline $\mathrm{H}$ & -1.63927 & 7.41191 & -2.51367 \\
\hline $\mathrm{H}$ & -1.17882 & 8.68920 & -1.37635 \\
\hline $\mathrm{H}$ & 0.58262 & 6.19083 & -1.95918 \\
\hline $\mathrm{H}$ & 0.98797 & 7.47861 & -0.81575 \\
\hline $\mathrm{H}$ & 0.96297 & 5.78573 & -0.28315 \\
\hline $\mathrm{H}$ & -2.52763 & 1.54280 & -2.97970 \\
\hline $\mathrm{H}$ & -0.21323 & 2.57719 & -3.24426 \\
\hline $\mathrm{H}$ & -0.97338 & 1.97303 & -4.72550 \\
\hline $\mathrm{H}$ & -0.92847 & 3.71126 & -4.41238 \\
\hline $\mathrm{H}$ & -4.50407 & 2.88556 & -3.71023 \\
\hline $\mathrm{H}$ & -3.42512 & 4.12998 & -4.36196 \\
\hline $\mathrm{H}$ & -3.46986 & 2.51696 & -5.09931 \\
\hline $\mathrm{H}$ & -4.19412 & 2.11969 & 1.49095 \\
\hline
\end{tabular}




$\begin{array}{llll}\mathrm{H} & -5.44354 & 4.27997 & 1.61053 \\ \mathrm{H} & -5.14520 & 3.58024 & 3.21429 \\ \mathrm{H} & -4.18050 & 4.95109 & 2.65393 \\ \mathrm{H} & -1.90194 & 1.91111 & 2.32671 \\ \mathrm{H} & -1.95479 & 3.56192 & 2.99663 \\ \mathrm{H} & -2.99986 & 2.29885 & 3.67189\end{array}$

\section{TS6-Z}

M06-2X/6-31G(d) Energy = -3926.918260

M06-2X/6-31G(d) Free Energy $=-3925.512380$

Number of Imaginary Frequencies $=1$ (-954.02)

$\begin{array}{lccc}\text { M06-2X/6-31G(d) } & \text { Geometry } & \\ \mathrm{C} & 3.55926 & 0.10823 & 1.39141 \\ \mathrm{C} & 4.72813 & -0.50160 & 0.85573 \\ \mathrm{C} & 3.47054 & 1.43798 & 1.76106 \\ \mathrm{C} & 6.10941 & -0.04824 & 1.22541 \\ \mathrm{C} & 4.59474 & -1.98620 & 0.56919 \\ \mathrm{C} & 7.17317 & -0.26975 & 0.33540 \\ \mathrm{C} & 8.46166 & 0.12439 & 0.66391 \\ \mathrm{C} & 8.74307 & 0.73909 & 1.89054 \\ \mathrm{C} & 7.68964 & 0.93209 & 2.78190 \\ \mathrm{C} & 6.39081 & 0.54312 & 2.45955 \\ \mathrm{C} & 10.14695 & 1.17093 & 2.22621 \\ \mathrm{~N} & 2.38408 & 2.05289 & 2.23602 \\ \mathrm{C} & 2.48395 & 3.41496 & 2.76551 \\ \mathrm{C} & 1.13386 & 4.11692 & 2.67023 \\ \mathrm{O} & 0.13522 & 3.35508 & 3.30790 \\ \mathrm{C} & -0.04981 & 2.13679 & 2.60834 \\ \mathrm{C} & 1.20464 & 1.28331 & 2.64491 \\ \mathrm{H} & 4.34902 & 2.07723 & 1.68778 \\ \mathrm{C} & 4.47529 & 0.46875 & -1.63037 \\ \mathrm{C} & 3.67585 & 1.64467 & -1.31655 \\ \mathrm{C} & 2.29742 & 1.54747 & -1.41636 \\ \mathrm{~N} & 1.75135 & 0.41877 & -1.92545 \\ \mathrm{C} & 2.44850 & -0.64660 & -2.42102 \\ \mathrm{C} & 3.82041 & -0.61516 & -2.37392 \\ \mathrm{C} & 1.56567 & -1.75212 & -2.93857 \\ \mathrm{C} & 1.31055 & 2.60523 & -1.03317 \\ \mathrm{C} & 4.74002 & -1.64347 & -2.91297 \\ \mathrm{C} & 4.31568 & 2.88607 & -0.82255 \\ \mathrm{C} & 4.30377 & -2.62837 & -3.97816 \\ \mathrm{O} & 5.90257 & -1.65203 & -2.53009 \\ \mathrm{C} & 5.82649 & 2.98721 & -0.90755 \\ \mathrm{O} & 3.67536 & 3.80953 & -0.33808 \\ \mathrm{C} & -6.67813 & -1.29006 & -0.24310\end{array}$




\begin{tabular}{|c|c|c|c|}
\hline $\mathrm{C}$ & -5.76474 & -0.19997 & -0.27491 \\
\hline $\mathrm{C}$ & -6.20984 & 1.02916 & -0.83606 \\
\hline $\mathrm{C}$ & -7.55120 & 1.15077 & -1.28523 \\
\hline $\mathrm{C}$ & -8.41519 & 0.09031 & -1.21447 \\
\hline $\mathrm{C}$ & -7.96387 & -1.14755 & -0.69922 \\
\hline $\mathrm{C}$ & -4.41460 & -0.30189 & 0.20088 \\
\hline $\mathrm{C}$ & -3.55380 & 0.75813 & -0.02538 \\
\hline $\mathrm{C}$ & -3.97824 & 1.98841 & -0.60800 \\
\hline $\mathrm{C}$ & -5.29761 & 2.10636 & -0.96653 \\
\hline $\mathrm{C}$ & -3.91650 & -1.53913 & 0.86508 \\
\hline $\mathrm{C}$ & -4.55330 & -2.12338 & 2.00970 \\
\hline $\mathrm{C}$ & -4.08006 & -3.37473 & 2.49784 \\
\hline $\mathrm{C}$ & -2.96014 & -3.99422 & 1.88241 \\
\hline $\mathrm{C}$ & -2.28187 & -3.39337 & 0.85234 \\
\hline $\mathrm{C}$ & -2.78795 & -2.15524 & 0.36778 \\
\hline $\mathrm{C}$ & -5.62334 & -1.49156 & 2.69906 \\
\hline $\mathrm{C}$ & -6.21133 & -2.08779 & 3.78585 \\
\hline $\mathrm{C}$ & -5.76513 & -3.34903 & 4.24549 \\
\hline $\mathrm{C}$ & -4.71970 & -3.97211 & 3.61570 \\
\hline $\mathrm{C}$ & -3.01256 & 3.12054 & -0.78506 \\
\hline $\mathrm{O}$ & -2.14007 & -1.59038 & -0.69988 \\
\hline $\mathrm{O}$ & -2.24636 & & 0.39766 \\
\hline $\mathrm{C}$ & -1.04265 & -3.97127 & 0.24830 \\
\hline $\mathrm{C}$ & -2.85416 & 4.06944 & 0.24765 \\
\hline $\mathrm{C}$ & -1.90073 & 5.07817 & 0.09280 \\
\hline $\mathrm{C}$ & -1.15526 & 5.21272 & -1.08042 \\
\hline $\mathrm{C}$ & -1.38938 & 4.30873 & -2.11237 \\
\hline $\mathrm{C}$ & -2.29707 & 3.25357 & -1.99014 \\
\hline $\mathrm{C}$ & 0.13035 & -4.08699 & 1.02165 \\
\hline $\mathrm{C}$ & 1.27963 & -4.62449 & 0.43575 \\
\hline $\mathrm{C}$ & 1.30733 & -5.03950 & -0.89347 \\
\hline $\mathrm{C}$ & 0.13883 & -4.90552 & -1.64045 \\
\hline $\mathrm{C}$ & -1.03454 & -4.37713 & -1.10179 \\
\hline $\mathrm{P}$ & -1.18237 & -0.29255 & -0.41017 \\
\hline $\mathrm{O}$ & -0.06246 & -0.58239 & 0.52688 \\
\hline $\mathrm{O}$ & -0.90052 & 0.25016 & -1.78627 \\
\hline $\mathrm{C}$ & -2.26592 & -4.30909 & -1.99373 \\
\hline $\mathrm{C}$ & -2.72633 & -5.72133 & -2.37924 \\
\hline $\mathrm{C}$ & -2.02047 & -3.45168 & -3.24072 \\
\hline $\mathrm{C}$ & 2.54037 & -5.67240 & -1.51286 \\
\hline $\mathrm{C}$ & 2.63623 & -7.15091 & -1.11447 \\
\hline $\mathrm{C}$ & 3.83588 & -4.93787 & -1.15910 \\
\hline $\mathrm{C}$ & 0.20935 & -3.64029 & 2.47483 \\
\hline $\mathrm{C}$ & 1.33918 & -2.62762 & 2.68343 \\
\hline $\mathrm{C}$ & 0.36302 & -4.84332 & 3.41272 \\
\hline $\mathrm{C}$ & -0.19106 & 6.36963 & -1.27782 \\
\hline
\end{tabular}




\begin{tabular}{|c|c|c|c|}
\hline $\mathrm{C}$ & 0.90506 & 6.42599 & -0.20936 \\
\hline $\mathrm{C}$ & -0.95421 & 7.69935 & -1.33398 \\
\hline $\mathrm{C}$ & -2.56432 & 2.34651 & -3.18291 \\
\hline $\mathrm{C}$ & -1.34472 & 2.14933 & -4.08771 \\
\hline $\mathrm{C}$ & -3.72649 & 2.90743 & -4.01642 \\
\hline $\mathrm{C}$ & -3.74822 & 4.03545 & 1.48271 \\
\hline $\mathrm{C}$ & -4.04212 & 5.42920 & 2.04583 \\
\hline $\mathrm{C}$ & -3.17891 & 3.13779 & 2.58603 \\
\hline $\mathrm{H}$ & 2.65252 & -0.48619 & 1.35719 \\
\hline $\mathrm{H}$ & 4.71407 & -2.54208 & 1.50711 \\
\hline $\mathrm{H}$ & 5.35605 & -2.33300 & -0.13345 \\
\hline $\mathrm{H}$ & 3.60028 & -2.21092 & 0.16770 \\
\hline $\mathrm{H}$ & 6.97657 & -0.73927 & -0.62732 \\
\hline $\mathrm{H}$ & 9.26938 & -0.04720 & -0.04357 \\
\hline $\mathrm{H}$ & 7.88523 & 1.38683 & 3.74958 \\
\hline $\mathrm{H}$ & 5.59399 & 0.67559 & 3.18481 \\
\hline $\mathrm{H}$ & 10.85090 & 0.34032 & 2.11504 \\
\hline $\mathrm{H}$ & 10.48066 & 1.97226 & 1.55852 \\
\hline $\mathrm{H}$ & 10.21482 & 1.53860 & 3.25293 \\
\hline $\mathrm{H}$ & 3.23921 & 3.95605 & 2.18913 \\
\hline $\mathrm{H}$ & 2.78387 & 3.37110 & 3.82232 \\
\hline $\mathrm{H}$ & 1.18540 & 5.08368 & 3.17801 \\
\hline $\mathrm{H}$ & 0.86363 & 4.28614 & 1.61768 \\
\hline $\mathrm{H}$ & -0.86282 & 1.59562 & 3.09457 \\
\hline $\mathrm{H}$ & -0.35524 & 2.33798 & 1.56927 \\
\hline $\mathrm{H}$ & 1.04439 & 0.44795 & 1.96350 \\
\hline $\mathrm{H}$ & 1.37751 & 0.90585 & 3.66307 \\
\hline $\mathrm{H}$ & 4.72125 & -0.04872 & -0.47874 \\
\hline $\mathrm{H}$ & 5.51230 & 0.63676 & -1.92618 \\
\hline $\mathrm{H}$ & 0.70013 & 0.35584 & -1.92045 \\
\hline $\mathrm{H}$ & 1.78190 & -2.69467 & -2.42525 \\
\hline $\mathrm{H}$ & 0.51842 & -1.50573 & -2.74869 \\
\hline $\mathrm{H}$ & 1.69315 & -1.90337 & -4.01322 \\
\hline $\mathrm{H}$ & 1.43474 & 2.85252 & 0.02406 \\
\hline $\mathrm{H}$ & 1.50157 & 3.52844 & -1.58827 \\
\hline $\mathrm{H}$ & 0.28824 & 2.27001 & -1.22061 \\
\hline $\mathrm{H}$ & 5.19390 & -3.15318 & -4.32644 \\
\hline $\mathrm{H}$ & 3.59014 & -3.35886 & -3.58806 \\
\hline $\mathrm{H}$ & 3.82641 & -2.11021 & -4.81532 \\
\hline $\mathrm{H}$ & 6.17904 & 2.81439 & -1.92967 \\
\hline $\mathrm{H}$ & 6.30651 & 2.23838 & -0.26627 \\
\hline $\mathrm{H}$ & 6.11979 & 3.98515 & -0.58172 \\
\hline $\mathrm{H}$ & -6.34378 & -2.24925 & 0.13600 \\
\hline $\mathrm{H}$ & -7.87242 & 2.10283 & -1.69990 \\
\hline $\mathrm{H}$ & -9.43737 & 0.19023 & -1.56571 \\
\hline $\mathrm{H}$ & -8.64042 & -1.99613 & -0.67123 \\
\hline
\end{tabular}




\begin{tabular}{|c|c|c|c|}
\hline $\mathrm{H}$ & -5.65501 & 3.04886 & -1.37560 \\
\hline $\mathrm{H}$ & -2.61589 & -4.95281 & 2.26489 \\
\hline $\mathrm{H}$ & -5.96609 & -0.51975 & 2.35983 \\
\hline $\mathrm{H}$ & -7.02296 & -1.58443 & 4.30196 \\
\hline $\mathrm{H}$ & -6.24337 & -3.81230 & 5.10276 \\
\hline $\mathrm{H}$ & -4.35200 & -4.93218 & 3.96882 \\
\hline $\mathrm{H}$ & -1.76697 & 5.80566 & 0.89035 \\
\hline $\mathrm{H}$ & -0.83943 & 4.42976 & -3.04293 \\
\hline $\mathrm{H}$ & 2.17820 & -4.71868 & 1.04279 \\
\hline $\mathrm{H}$ & 0.14383 & -5.23099 & -2.68009 \\
\hline $\mathrm{H}$ & -3.08082 & -3.84509 & -1.43179 \\
\hline $\mathrm{H}$ & -2.92349 & -6.32736 & -1.48955 \\
\hline $\mathrm{H}$ & -3.64346 & -5.67455 & -2.97554 \\
\hline $\mathrm{H}$ & -1.96443 & -6.23618 & -2.97506 \\
\hline $\mathrm{H}$ & -1.75477 & -2.42863 & -2.96133 \\
\hline $\mathrm{H}$ & -1.21826 & -3.87167 & -3.85921 \\
\hline $\mathrm{H}$ & -2.92586 & -3.41438 & -3.85579 \\
\hline $\mathrm{H}$ & 2.41357 & -5.62620 & -2.60407 \\
\hline $\mathrm{H}$ & 1.73263 & -7.69427 & -1.40526 \\
\hline $\mathrm{H}$ & 3.49950 & -7.63018 & -1.58836 \\
\hline $\mathrm{H}$ & 2.74794 & -7.24126 & -0.02820 \\
\hline $\mathrm{H}$ & 3.76547 & -3.86922 & -1.38651 \\
\hline $\mathrm{H}$ & 4.07014 & -5.03147 & -0.09271 \\
\hline $\mathrm{H}$ & 4.68108 & -5.35140 & -1.71943 \\
\hline $\mathrm{H}$ & -0.72144 & -3.12709 & 2.72760 \\
\hline $\mathrm{H}$ & 1.19426 & -1.79801 & 1.98849 \\
\hline $\mathrm{H}$ & 1.32310 & -2.24347 & 3.70969 \\
\hline $\mathrm{H}$ & 2.32577 & -3.07473 & 2.51258 \\
\hline $\mathrm{H}$ & -0.46272 & -5.55249 & 3.29538 \\
\hline $\mathrm{H}$ & 1.29429 & -5.38257 & 3.20457 \\
\hline $\mathrm{H}$ & 0.38953 & -4.51611 & 4.45747 \\
\hline $\mathrm{H}$ & 0.29719 & 6.22138 & -2.25025 \\
\hline $\mathrm{H}$ & 1.51568 & 5.51666 & -0.20483 \\
\hline $\mathrm{H}$ & 0.46924 & 6.55623 & 0.78815 \\
\hline $\mathrm{H}$ & 1.57122 & 7.27593 & -0.39222 \\
\hline $\mathrm{H}$ & -1.44868 & 7.89928 & -0.37678 \\
\hline $\mathrm{H}$ & -0.27269 & 8.53091 & -1.54228 \\
\hline $\mathrm{H}$ & -1.72419 & 7.67740 & -2.11058 \\
\hline $\mathrm{H}$ & -2.84736 & 1.36230 & -2.80014 \\
\hline $\mathrm{H}$ & -0.45591 & 1.89102 & -3.50792 \\
\hline $\mathrm{H}$ & -1.53929 & 1.33074 & -4.78758 \\
\hline $\mathrm{H}$ & -1.13422 & 3.04569 & -4.68292 \\
\hline $\mathrm{H}$ & -4.64945 & 2.97214 & -3.43464 \\
\hline $\mathrm{H}$ & -3.48276 & 3.91270 & -4.37951 \\
\hline $\mathrm{H}$ & -3.91676 & 2.26786 & -4.88518 \\
\hline $\mathrm{H}$ & -4.70588 & 3.60589 & 1.16892 \\
\hline
\end{tabular}




$\begin{array}{llll}\mathrm{H} & -4.37897 & 6.11871 & 1.26547 \\ \mathrm{H} & -4.82456 & 5.36134 & 2.80815 \\ \mathrm{H} & -3.15964 & 5.86311 & 2.52821 \\ \mathrm{H} & -2.98407 & 2.12643 & 2.21832 \\ \mathrm{H} & -2.23854 & 3.55548 & 2.96248 \\ \mathrm{H} & -3.88345 & 3.07210 & 3.42263\end{array}$

\section{TS7-E}

M06-2X/6-31G(d) Energy = -3926.925627

M06-2X/6-31G(d) Free Energy = -3925.519789

Number of Imaginary Frequencies $=1(-1004.91)$

$\begin{array}{lrrr}\text { M06-2X/6-31G(d) } & \text { Geometry } & \\ \mathrm{C} & -4.33496 & 0.34412 & 0.00311 \\ \mathrm{C} & -4.42520 & -0.54710 & 1.11258 \\ \mathrm{C} & -3.13635 & 0.75370 & -0.55391 \\ \mathrm{C} & -5.78330 & -0.66276 & 1.74929 \\ \mathrm{C} & -3.26944 & -0.68667 & 2.08749 \\ \mathrm{C} & -6.62099 & 0.45442 & 1.82872 \\ \mathrm{C} & -7.86098 & 0.37078 & 2.45544 \\ \mathrm{C} & -8.30636 & -0.82657 & 3.01443 \\ \mathrm{C} & -7.46317 & -1.93939 & 2.93746 \\ \mathrm{C} & -6.22108 & -1.86413 & 2.32080 \\ \mathrm{C} & -9.65996 & -0.93018 & 3.66873 \\ \mathrm{~N} & -2.99561 & 1.52576 & -1.63657 \\ \mathrm{C} & -4.14771 & 2.10263 & -2.32401 \\ \mathrm{C} & -3.80488 & 2.39760 & -3.77896 \\ \mathrm{O} & -2.63539 & 3.17554 & -3.89185 \\ \mathrm{C} & -1.52111 & 2.47485 & -3.37272 \\ \mathrm{C} & -1.69774 & 2.16867 & -1.89339 \\ \mathrm{H} & -2.18541 & 0.46107 & -0.10056 \\ \mathrm{C} & -3.85146 & -2.80010 & -0.23880 \\ \mathrm{C} & -2.66944 & -3.31865 & 0.45375 \\ \mathrm{C} & -1.42501 & -2.91021 & 0.03543 \\ \mathrm{~N} & -1.32554 & -2.20585 & -1.13211 \\ \mathrm{C} & -2.36402 & -1.85757 & -1.93125 \\ \mathrm{C} & -3.65123 & -2.16205 & -1.53109 \\ \mathrm{C} & -1.96653 & -1.17315 & -3.20270 \\ \mathrm{C} & -0.11098 & -3.09036 & 0.73075 \\ \mathrm{C} & -4.82736 & -1.69339 & -2.30576 \\ \mathrm{C} & -2.96379 & -4.14816 & 1.64820 \\ \mathrm{C} & -6.19795 & -2.04808 & -1.76338 \\ \mathrm{O} & -4.72555 & -1.03497 & -3.33051 \\ \mathrm{C} & -1.88778 & -4.80202 & 2.49023 \\ \mathrm{O} & -4.13329 & -4.31443 & 1.96652 \\ \mathrm{C} & 6.35421 & 1.58861 & 0.15838\end{array}$




\begin{tabular}{|c|c|c|c|}
\hline $\mathrm{C}$ & 5.57098 & 0.40276 & 0.10420 \\
\hline $\mathrm{C}$ & 6.16742 & -0.77189 & -0.43046 \\
\hline $\mathrm{C}$ & 7.52600 & -0.74434 & -0.84111 \\
\hline $\mathrm{C}$ & 8.26194 & 0.40784 & -0.75486 \\
\hline $\mathrm{C}$ & 7.66059 & 1.58908 & -0.26027 \\
\hline $\mathrm{C}$ & 4.20474 & 0.35101 & 0.53848 \\
\hline $\mathrm{C}$ & 3.47148 & -0.79359 & 0.30429 \\
\hline $\mathrm{C}$ & 4.05293 & -1.97540 & -0.23974 \\
\hline $\mathrm{C}$ & 5.38681 & -1.94796 & -0.56138 \\
\hline $\mathrm{C}$ & 3.55864 & 1.52020 & 1.18784 \\
\hline $\mathrm{C}$ & 4.10934 & 2.12756 & 2.36327 \\
\hline $\mathrm{C}$ & 3.54497 & 3.34207 & 2.84058 \\
\hline $\mathrm{C}$ & 2.45598 & 3.91981 & 2.14119 \\
\hline $\mathrm{C}$ & 1.86926 & 3.29903 & 1.06526 \\
\hline $\mathrm{C}$ & 2.40880 & 2.05312 & 0.64062 \\
\hline $\mathrm{C}$ & 5.18529 & 1.55089 & 3.09151 \\
\hline $\mathrm{C}$ & 5.68203 & 2.16284 & 4.21409 \\
\hline $\mathrm{C}$ & 5.13732 & 3.38656 & 4.67031 \\
\hline $\mathrm{C}$ & 4.09019 & 3.95894 & 3.99729 \\
\hline $\mathrm{C}$ & 3.25990 & -3.23457 & -0.39107 \\
\hline $\mathrm{O}$ & 1.81911 & 1.42829 & -0.43452 \\
\hline $\mathrm{O}$ & 2.15104 & -0.82637 & 0.69234 \\
\hline $\mathrm{C}$ & 0.77642 & 3.99043 & 0.31680 \\
\hline $\mathrm{C}$ & 3.13721 & -4.10989 & 0.70194 \\
\hline $\mathrm{C}$ & 2.39683 & -5.28562 & 0.54464 \\
\hline $\mathrm{C}$ & 1.77118 & -5.60603 & -0.65547 \\
\hline $\mathrm{C}$ & 1.92400 & -4.73063 & -1.73181 \\
\hline $\mathrm{C}$ & 2.65995 & -3.55018 & -1.62867 \\
\hline $\mathrm{C}$ & -0.44681 & 4.28437 & 0.95279 \\
\hline $\mathrm{C}$ & -1.36747 & 5.10727 & 0.30083 \\
\hline $\mathrm{C}$ & -1.12282 & 5.63804 & -0.96565 \\
\hline $\mathrm{C}$ & 0.06712 & 5.28514 & -1.59779 \\
\hline $\mathrm{C}$ & 1.02764 & 4.47714 & -0.98253 \\
\hline $\mathrm{P}$ & 1.02463 & 0.00642 & -0.18238 \\
\hline $\mathrm{O}$ & -0.17185 & 0.16763 & 0.69556 \\
\hline $\mathrm{O}$ & 0.87408 & -0.61244 & -1.54526 \\
\hline $\mathrm{C}$ & 2.33563 & 4.22236 & -1.71998 \\
\hline $\mathrm{C}$ & 3.07132 & 5.53804 & -2.00459 \\
\hline $\mathrm{C}$ & 2.10954 & 3.42664 & -3.00961 \\
\hline $\mathrm{C}$ & -2.11307 & 6.58003 & -1.62406 \\
\hline $\mathrm{C}$ & -2.31665 & 7.84326 & -0.77986 \\
\hline $\mathrm{C}$ & -3.44990 & 5.88582 & -1.90465 \\
\hline $\mathrm{C}$ & -0.82053 & 3.71337 & 2.31277 \\
\hline $\mathrm{C}$ & -1.97073 & 2.70965 & 2.16692 \\
\hline $\mathrm{C}$ & -1.16161 & 4.81378 & 3.32330 \\
\hline $\mathrm{C}$ & 0.92546 & -6.85823 & -0.78863 \\
\hline
\end{tabular}




\begin{tabular}{|c|c|c|c|}
\hline $\mathrm{C}$ & 1.53313 & -7.83937 & -1.79738 \\
\hline $\mathrm{C}$ & -0.51963 & -6.51624 & -1.17247 \\
\hline $\mathrm{C}$ & 2.82541 & -2.65065 & -2.84396 \\
\hline $\mathrm{C}$ & 1.60358 & -2.66649 & -3.76689 \\
\hline $\mathrm{C}$ & 4.07544 & -3.04825 & -3.64192 \\
\hline $\mathrm{C}$ & 3.73531 & -3.78644 & 2.06278 \\
\hline $\mathrm{C}$ & 4.50022 & -4.97034 & 2.66341 \\
\hline $\mathrm{C}$ & 2.63948 & -3.29873 & 3.02004 \\
\hline $\mathrm{H}$ & -5.27056 & 0.63878 & -0.46119 \\
\hline $\mathrm{H}$ & -3.37298 & -1.61209 & 2.66391 \\
\hline $\mathrm{H}$ & -3.31942 & 0.14872 & 2.79412 \\
\hline $\mathrm{H}$ & -2.28449 & -0.66562 & 1.61012 \\
\hline $\mathrm{H}$ & -6.28624 & 1.40463 & 1.42296 \\
\hline $\mathrm{H}$ & -8.48990 & 1.25546 & 2.51511 \\
\hline $\mathrm{H}$ & -7.78646 & -2.88426 & 3.36763 \\
\hline $\mathrm{H}$ & -5.59119 & -2.74868 & 2.26705 \\
\hline $\mathrm{H}$ & -10.07585 & 0.05835 & 3.87947 \\
\hline $\mathrm{H}$ & -9.60217 & -1.48423 & 4.61028 \\
\hline $\mathrm{H}$ & -10.36805 & -1.45911 & 3.02135 \\
\hline $\mathrm{H}$ & -4.45525 & 3.02348 & -1.80813 \\
\hline $\mathrm{H}$ & -4.96988 & 1.38498 & -2.30502 \\
\hline $\mathrm{H}$ & -4.61567 & 2.96877 & -4.23755 \\
\hline $\mathrm{H}$ & -3.69067 & 1.44913 & -4.32639 \\
\hline $\mathrm{H}$ & -1.36414 & 1.55089 & -3.94855 \\
\hline $\mathrm{H}$ & -0.65081 & 3.12068 & -3.49962 \\
\hline $\mathrm{H}$ & -1.64708 & 3.10296 & -1.32048 \\
\hline $\mathrm{H}$ & -0.90443 & 1.50054 & -1.54587 \\
\hline $\mathrm{H}$ & -4.28756 & -1.80684 & 0.50839 \\
\hline $\mathrm{H}$ & -4.74071 & -3.41985 & -0.11658 \\
\hline $\mathrm{H}$ & -0.40312 & -1.78105 & -1.36339 \\
\hline $\mathrm{H}$ & -2.57157 & -0.28054 & -3.34504 \\
\hline $\mathrm{H}$ & -0.90477 & -0.91460 & -3.17333 \\
\hline $\mathrm{H}$ & -2.16917 & -1.82679 & -4.05711 \\
\hline $\mathrm{H}$ & 0.05350 & -4.11064 & 1.06734 \\
\hline $\mathrm{H}$ & 0.70876 & -2.83460 & 0.05731 \\
\hline $\mathrm{H}$ & -0.05751 & -2.40991 & 1.58853 \\
\hline $\mathrm{H}$ & -6.95073 & -1.58465 & -2.40115 \\
\hline $\mathrm{H}$ & -6.34029 & -3.13480 & -1.76684 \\
\hline $\mathrm{H}$ & -6.32747 & -1.70783 & -0.72937 \\
\hline $\mathrm{H}$ & -2.39244 & -5.36529 & 3.27534 \\
\hline $\mathrm{H}$ & -1.22828 & -4.05623 & 2.94279 \\
\hline $\mathrm{H}$ & -1.26820 & -5.48246 & 1.89742 \\
\hline $\mathrm{H}$ & 5.90396 & 2.50462 & 0.52476 \\
\hline $\mathrm{H}$ & 7.96493 & -1.65625 & -1.23767 \\
\hline $\mathrm{H}$ & 9.29847 & 0.42247 & -1.07657 \\
\hline $\mathrm{H}$ & 8.23789 & 2.50742 & -0.21704 \\
\hline
\end{tabular}




\begin{tabular}{|c|c|c|c|}
\hline $\mathrm{H}$ & 5.86118 & -2.85324 & -0.93304 \\
\hline $\mathrm{H}$ & 2.07198 & 4.88372 & 2.46932 \\
\hline $\mathrm{H}$ & 5.60359 & 0.60789 & 2.75579 \\
\hline $\mathrm{H}$ & 6.49811 & 1.70169 & 4.76166 \\
\hline $\mathrm{H}$ & 5.54467 & 3.86203 & 5.55698 \\
\hline $\mathrm{H}$ & 3.65152 & 4.89191 & 4.34163 \\
\hline $\mathrm{H}$ & 2.28283 & -5.96056 & 1.39149 \\
\hline $\mathrm{H}$ & 1.45039 & -4.97261 & -2.68029 \\
\hline $\mathrm{H}$ & -2.30420 & 5.34403 & 0.80297 \\
\hline $\mathrm{H}$ & 0.26770 & 5.68201 & -2.59197 \\
\hline $\mathrm{H}$ & 2.98925 & 3.62359 & -1.08175 \\
\hline $\mathrm{H}$ & 3.24618 & 6.09702 & -1.08015 \\
\hline $\mathrm{H}$ & 4.03948 & 5.33694 & -2.47468 \\
\hline $\mathrm{H}$ & 2.49710 & 6.17844 & -2.68273 \\
\hline $\mathrm{H}$ & 1.62014 & 2.47123 & -2.79535 \\
\hline $\mathrm{H}$ & 1.49580 & 3.99424 & -3.71989 \\
\hline $\mathrm{H}$ & 3.06708 & 3.21531 & -3.49685 \\
\hline $\mathrm{H}$ & -1.68461 & 6.88190 & -2.58824 \\
\hline $\mathrm{H}$ & -1.36530 & 8.34736 & -0.58666 \\
\hline $\mathrm{H}$ & -2.98384 & 8.54473 & -1.29133 \\
\hline $\mathrm{H}$ & -2.76845 & 7.59623 & 0.18725 \\
\hline $\mathrm{H}$ & -3.30180 & 5.02826 & -2.56754 \\
\hline $\mathrm{H}$ & -3.90679 & 5.53506 & -0.97086 \\
\hline $\mathrm{H}$ & -4.15220 & 6.57901 & -2.38017 \\
\hline $\mathrm{H}$ & 0.03597 & 3.15614 & 2.70028 \\
\hline $\mathrm{H}$ & -1.64159 & 1.86007 & 1.56097 \\
\hline $\mathrm{H}$ & -2.27103 & 2.33417 & 3.15197 \\
\hline $\mathrm{H}$ & -2.84929 & 3.16919 & 1.69680 \\
\hline $\mathrm{H}$ & -0.34135 & 5.53213 & 3.42272 \\
\hline $\mathrm{H}$ & -2.05703 & 5.36994 & 3.02485 \\
\hline $\mathrm{H}$ & -1.35638 & 4.37688 & 4.30800 \\
\hline $\mathrm{H}$ & 0.90891 & -7.34920 & 0.19361 \\
\hline $\mathrm{H}$ & 2.55663 & -8.10569 & -1.51873 \\
\hline $\mathrm{H}$ & 1.56192 & -7.39509 & -2.79837 \\
\hline $\mathrm{H}$ & 0.93822 & -8.75689 & -1.85360 \\
\hline $\mathrm{H}$ & -0.55922 & -6.04433 & -2.16037 \\
\hline $\mathrm{H}$ & -1.13613 & -7.42040 & -1.20797 \\
\hline $\mathrm{H}$ & -0.97348 & -5.81917 & -0.45903 \\
\hline $\mathrm{H}$ & 2.94575 & -1.62520 & -2.48381 \\
\hline $\mathrm{H}$ & 0.67626 & -2.59156 & -3.19397 \\
\hline $\mathrm{H}$ & 1.64741 & -1.81661 & -4.45452 \\
\hline $\mathrm{H}$ & 1.56399 & -3.58023 & -4.37164 \\
\hline $\mathrm{H}$ & 4.98627 & -2.94735 & -3.04634 \\
\hline $\mathrm{H}$ & 3.99908 & -4.09018 & -3.97399 \\
\hline $\mathrm{H}$ & 4.17834 & -2.41414 & -4.52898 \\
\hline $\mathrm{H}$ & 4.45015 & -2.96778 & 1.93346 \\
\hline
\end{tabular}




$\begin{array}{llll}\mathrm{H} & 5.25586 & -5.34890 & 1.96857 \\ \mathrm{H} & 5.00326 & -4.66226 & 3.58548 \\ \mathrm{H} & 3.83012 & -5.79818 & 2.91841 \\ \mathrm{H} & 2.14852 & -2.40441 & 2.62483 \\ \mathrm{H} & 1.88042 & -4.07921 & 3.16113 \\ \mathrm{H} & 3.06255 & -3.05838 & 4.00127\end{array}$

\section{TS7-Z}

M06-2X/6-31G(d) Energy = -3926.920926

M06-2X/6-31G(d) Free Energy $=-3925.515229$

Number of Imaginary Frequencies $=1$ (-991.77)

$\begin{array}{lccc}\text { M06-2X/6-31G(d) } & \text { Geometry } & \\ \mathrm{C} & -5.09956 & -0.41276 & 0.54198 \\ \mathrm{C} & -4.92669 & -1.41781 & 1.55471 \\ \mathrm{C} & -4.14830 & 0.46889 & 0.06887 \\ \mathrm{~N} & -4.27373 & 1.32177 & -0.95654 \\ \mathrm{C} & -5.52283 & 1.51391 & -1.68916 \\ \mathrm{C} & -5.22490 & 1.91371 & -3.12965 \\ \mathrm{O} & -4.37274 & 3.03663 & -3.18766 \\ \mathrm{C} & -3.12130 & 2.74932 & -2.59494 \\ \mathrm{C} & -3.28871 & 2.39868 & -1.12320 \\ \mathrm{H} & -3.17873 & 0.54343 & 0.54994 \\ \mathrm{C} & -3.90756 & -3.28312 & -0.11184 \\ \mathrm{C} & -2.63311 & -3.62182 & 0.52491 \\ \mathrm{C} & -1.47838 & -3.04575 & 0.05746 \\ \mathrm{~N} & -1.54431 & -2.23989 & -1.04955 \\ \mathrm{C} & -2.67022 & -1.94181 & -1.73828 \\ \mathrm{C} & -3.87149 & -2.49389 & -1.33305 \\ \mathrm{C} & -2.47138 & -1.03350 & -2.91206 \\ \mathrm{C} & -0.10595 & -3.10527 & 0.64865 \\ \mathrm{C} & -5.12113 & -2.21247 & -2.07139 \\ \mathrm{C} & -2.80468 & -4.40040 & 1.78286 \\ \mathrm{C} & -6.34367 & -3.03401 & -1.71050 \\ \mathrm{O} & -5.19772 & -1.36656 & -2.95163 \\ \mathrm{C} & -1.64852 & -4.78295 & 2.67874 \\ \mathrm{O} & -3.94323 & -4.69566 & 2.11525 \\ \mathrm{C} & 5.26449 & 2.07190 & 2.18779 \\ \mathrm{C} & 4.03055 & 2.54264 & 1.66031 \\ \mathrm{C} & 3.44500 & 3.69774 & 2.24595 \\ \mathrm{C} & 4.12116 & 4.36893 & 3.29897 \\ \mathrm{C} & 5.31839 & 3.90225 & 3.77344 \\ \mathrm{C} & 5.88788 & 2.73298 & 3.21522 \\ \mathrm{C} & 3.34350 & 1.88506 & 0.58865 \\ \mathrm{C} & 2.07554 & 2.31070 & 0.24336 \\ \mathrm{C} & 1.48652 & 3.47868 & 0.80118\end{array}$




\begin{tabular}{|c|c|c|c|}
\hline $\mathrm{C}$ & 2.19210 & 4.15359 & 1.76882 \\
\hline $\mathrm{C}$ & 3.95522 & 0.74763 & -0.14380 \\
\hline $\mathrm{C}$ & 5.22509 & 0.87271 & -0.79722 \\
\hline $\mathrm{C}$ & 5.80677 & -0.27819 & -1.39511 \\
\hline $\mathrm{C}$ & 5.09810 & -1.50545 & -1.36734 \\
\hline $\mathrm{C}$ & 3.83873 & -1.60769 & -0.83087 \\
\hline $\mathrm{C}$ & 3.27357 & -0.44971 & -0.22345 \\
\hline $\mathrm{C}$ & 5.92271 & 2.10784 & -0.89674 \\
\hline $\mathrm{C}$ & 7.14119 & 2.17907 & -1.52273 \\
\hline $\mathrm{C}$ & 7.73431 & 1.02335 & -2.08366 \\
\hline $\mathrm{C}$ & 7.07576 & -0.17637 & -2.02325 \\
\hline $\mathrm{C}$ & 0.17731 & 4.04119 & 0.35039 \\
\hline $\mathrm{O}$ & 2.03632 & -0.54918 & 0.37349 \\
\hline $\mathrm{O}$ & 1.38679 & 1.63922 & -0.74126 \\
\hline $\mathrm{C}$ & 3.12857 & -2.92353 & -0.83290 \\
\hline $\mathrm{C}$ & 0.05797 & 4.61641 & -0.93151 \\
\hline $\mathrm{C}$ & -1.08573 & 5.35714 & -1.23660 \\
\hline $\mathrm{C}$ & -2.11773 & 5.54399 & -0.31646 \\
\hline $\mathrm{C}$ & -2.00436 & 4.91047 & 0.91829 \\
\hline $\mathrm{C}$ & -0.88454 & 4.15247 & 1.26935 \\
\hline $\mathrm{C}$ & 3.20012 & -3.75093 & 0.30130 \\
\hline $\mathrm{C}$ & 2.57845 & -5.00243 & 0.26383 \\
\hline $\mathrm{C}$ & 1.87685 & -5.44285 & -0.85345 \\
\hline $\mathrm{C}$ & 1.81667 & -4.60190 & -1.96581 \\
\hline $\mathrm{C}$ & 2.43079 & -3.34926 & -1.98334 \\
\hline $\mathrm{P}$ & 0.74645 & 0.16504 & -0.38061 \\
\hline $\mathrm{O}$ & 0.50791 & -0.52749 & -1.69305 \\
\hline $\mathrm{O}$ & -0.34601 & 0.26930 & 0.63014 \\
\hline $\mathrm{C}$ & 2.35422 & -2.48815 & -3.23539 \\
\hline $\mathrm{C}$ & 1.00729 & -2.60769 & -3.95558 \\
\hline $\mathrm{C}$ & 3.48826 & -2.84360 & -4.20717 \\
\hline $\mathrm{C}$ & 1.17190 & -6.78611 & -0.85594 \\
\hline $\mathrm{C}$ & 1.75699 & -7.72397 & -1.91773 \\
\hline $\mathrm{C}$ & -0.33979 & -6.62148 & -1.05529 \\
\hline $\mathrm{C}$ & 3.88920 & -3.30689 & 1.58283 \\
\hline $\mathrm{C}$ & 4.88716 & -4.35017 & 2.09635 \\
\hline $\mathrm{C}$ & 2.84667 & -2.96576 & 2.65690 \\
\hline $\mathrm{C}$ & -3.29341 & 6.45846 & -0.61067 \\
\hline $\mathrm{C}$ & -3.94317 & 6.20249 & -1.97315 \\
\hline $\mathrm{C}$ & -2.84953 & 7.92324 & -0.49497 \\
\hline $\mathrm{C}$ & -0.88289 & 3.44671 & 2.61774 \\
\hline $\mathrm{C}$ & -1.99061 & 2.38723 & 2.65361 \\
\hline $\mathrm{C}$ & -1.01242 & 4.43175 & 3.78414 \\
\hline $\mathrm{C}$ & 1.14145 & 4.49069 & -1.99205 \\
\hline $\mathrm{C}$ & 1.65925 & 5.86340 & -2.43792 \\
\hline $\mathrm{C}$ & 0.63312 & 3.67466 & -3.18655 \\
\hline
\end{tabular}




\begin{tabular}{|c|c|c|c|}
\hline $\mathrm{H}$ & -6.07367 & -0.41687 & 0.06061 \\
\hline $\mathrm{H}$ & -6.11149 & 2.29948 & -1.19363 \\
\hline $\mathrm{H}$ & -6.08920 & 0.58258 & -1.69653 \\
\hline $\mathrm{H}$ & -4.77912 & 1.05832 & -3.65682 \\
\hline $\mathrm{H}$ & -6.15355 & 2.19103 & -3.63371 \\
\hline $\mathrm{H}$ & -2.62382 & 1.93232 & -3.13743 \\
\hline $\mathrm{H}$ & -2.50779 & 3.64868 & -2.68097 \\
\hline $\mathrm{H}$ & -3.64156 & 3.28808 & -0.58342 \\
\hline $\mathrm{H}$ & -2.33335 & 2.08734 & -0.68330 \\
\hline $\mathrm{H}$ & -4.46292 & -2.50870 & 0.75883 \\
\hline $\mathrm{H}$ & -4.65746 & -4.07236 & -0.03775 \\
\hline $\mathrm{H}$ & -0.68285 & -1.72104 & -1.32826 \\
\hline $\mathrm{H}$ & -1.42077 & -0.74880 & -2.99983 \\
\hline $\mathrm{H}$ & -2.82395 & -1.50880 & -3.83090 \\
\hline $\mathrm{H}$ & -3.08736 & -0.14393 & -2.77153 \\
\hline $\mathrm{H}$ & -0.04145 & -2.38714 & 1.47449 \\
\hline $\mathrm{H}$ & 0.15532 & -4.09427 & 1.01539 \\
\hline $\mathrm{H}$ & 0.63745 & -2.81551 & -0.09725 \\
\hline $\mathrm{H}$ & -6.15709 & -4.09714 & -1.89912 \\
\hline $\mathrm{H}$ & -6.59465 & -2.93674 & -0.65038 \\
\hline $\mathrm{H}$ & -7.18137 & -2.69714 & -2.32115 \\
\hline $\mathrm{H}$ & -0.94420 & -5.44824 & 2.16872 \\
\hline $\mathrm{H}$ & -2.06587 & -5.29410 & 3.54664 \\
\hline $\mathrm{H}$ & -1.10248 & -3.89238 & 3.00633 \\
\hline $\mathrm{H}$ & 5.70572 & 1.17078 & 1.77573 \\
\hline $\mathrm{H}$ & 3.66107 & 5.25616 & 3.72639 \\
\hline $\mathrm{H}$ & 5.82674 & 4.41797 & 4.58204 \\
\hline $\mathrm{H}$ & 6.82555 & 2.35269 & 3.60855 \\
\hline $\mathrm{H}$ & 1.76827 & 5.06188 & 2.19198 \\
\hline $\mathrm{H}$ & 5.56659 & -2.39067 & -1.79088 \\
\hline $\mathrm{H}$ & 5.47422 & 3.00336 & -0.48060 \\
\hline $\mathrm{H}$ & 7.65357 & 3.13346 & -1.59425 \\
\hline $\mathrm{H}$ & 8.70154 & 1.09442 & -2.57112 \\
\hline $\mathrm{H}$ & 7.50707 & -1.07048 & -2.46614 \\
\hline $\mathrm{H}$ & -1.15518 & 5.82772 & -2.21607 \\
\hline $\mathrm{H}$ & -2.81686 & 5.01623 & 1.63613 \\
\hline $\mathrm{H}$ & 2.62224 & -5.64478 & 1.14225 \\
\hline $\mathrm{H}$ & 1.27103 & -4.93044 & -2.84749 \\
\hline $\mathrm{H}$ & 2.46267 & -1.44456 & -2.92780 \\
\hline $\mathrm{H}$ & 0.17528 & -2.54227 & -3.25023 \\
\hline $\mathrm{H}$ & 0.90253 & -1.79402 & -4.67965 \\
\hline $\mathrm{H}$ & 0.92291 & -3.55225 & -4.50583 \\
\hline $\mathrm{H}$ & 4.47221 & -2.66993 & -3.76396 \\
\hline $\mathrm{H}$ & 3.42666 & -3.89969 & -4.49493 \\
\hline $\mathrm{H}$ & 3.41451 & -2.23776 & -5.11661 \\
\hline $\mathrm{H}$ & 1.33630 & -7.24462 & 0.12825 \\
\hline
\end{tabular}




\begin{tabular}{|c|c|c|c|}
\hline $\mathrm{H}$ & 2.83197 & -7.86192 & -1.77091 \\
\hline $\mathrm{H}$ & 1.27208 & -8.70492 & -1.87849 \\
\hline $\mathrm{H}$ & 1.60476 & -7.31381 & -2.92209 \\
\hline $\mathrm{H}$ & -0.77809 & -5.96561 & -0.29505 \\
\hline $\mathrm{H}$ & -0.55733 & -6.17922 & -2.03382 \\
\hline $\mathrm{H}$ & -0.84581 & -7.59123 & -1.00494 \\
\hline $\mathrm{H}$ & 4.45257 & -2.39331 & 1.36877 \\
\hline $\mathrm{H}$ & 5.61744 & -4.61201 & 1.32482 \\
\hline $\mathrm{H}$ & 5.42779 & -3.95917 & 2.96422 \\
\hline $\mathrm{H}$ & 4.38320 & -5.27037 & 2.41063 \\
\hline $\mathrm{H}$ & 2.19488 & -2.15629 & 2.31445 \\
\hline $\mathrm{H}$ & 2.22612 & -3.84185 & 2.88552 \\
\hline $\mathrm{H}$ & 3.33828 & -2.64839 & 3.58305 \\
\hline $\mathrm{H}$ & -4.04943 & 6.27417 & 0.16458 \\
\hline $\mathrm{H}$ & -4.31182 & 5.17750 & -2.07509 \\
\hline $\mathrm{H}$ & -3.23710 & 6.38715 & -2.79064 \\
\hline $\mathrm{H}$ & -4.78970 & 6.88190 & -2.11825 \\
\hline $\mathrm{H}$ & -2.09219 & 8.15086 & -1.25357 \\
\hline $\mathrm{H}$ & -3.69700 & 8.60004 & -0.64655 \\
\hline $\mathrm{H}$ & -2.41250 & 8.12624 & 0.48713 \\
\hline $\mathrm{H}$ & 0.06615 & 2.91492 & 2.72659 \\
\hline $\mathrm{H}$ & -1.79205 & 1.63434 & 1.88538 \\
\hline $\mathrm{H}$ & -2.01062 & 1.87865 & 3.62422 \\
\hline $\mathrm{H}$ & -2.97947 & 2.83195 & 2.48518 \\
\hline $\mathrm{H}$ & -0.21217 & 5.17873 & 3.76783 \\
\hline $\mathrm{H}$ & -1.96836 & 4.96593 & 3.75080 \\
\hline $\mathrm{H}$ & -0.96335 & 3.89829 & 4.73894 \\
\hline $\mathrm{H}$ & 1.98931 & 3.94986 & -1.56497 \\
\hline $\mathrm{H}$ & 2.02643 & 6.44124 & -1.58421 \\
\hline $\mathrm{H}$ & 2.48034 & 5.74399 & -3.15214 \\
\hline $\mathrm{H}$ & 0.87466 & 6.44874 & -2.92946 \\
\hline $\mathrm{H}$ & 0.30459 & 2.68198 & -2.86421 \\
\hline $\mathrm{H}$ & -0.20375 & 4.18356 & -3.68074 \\
\hline $\mathrm{H}$ & 1.42924 & 3.54637 & -3.92722 \\
\hline $\mathrm{C}$ & -1.76313 & -1.40844 & 4.53109 \\
\hline $\mathrm{C}$ & -1.49873 & -1.04192 & 3.21204 \\
\hline $\mathrm{C}$ & -2.49700 & -1.06979 & 2.24233 \\
\hline $\mathrm{C}$ & -3.82005 & -1.41240 & 2.55998 \\
\hline $\mathrm{C}$ & -4.07138 & -1.80625 & 3.88646 \\
\hline $\mathrm{C}$ & -3.06733 & -1.80364 & 4.84491 \\
\hline $\mathrm{C}$ & -0.68126 & -1.36238 & 5.57793 \\
\hline $\mathrm{H}$ & -0.50882 & -0.70615 & 2.90853 \\
\hline $\mathrm{H}$ & -2.18613 & -0.81739 & 1.23709 \\
\hline $\mathrm{H}$ & -5.06476 & -2.11659 & 4.18753 \\
\hline $\mathrm{H}$ & -3.30387 & -2.10910 & 5.86098 \\
\hline $\mathrm{H}$ & -0.53510 & -0.33786 & 5.93810 \\
\hline
\end{tabular}




$\begin{array}{lrrr}\mathrm{H} & -0.93263 & -1.98614 & 6.43978 \\ \mathrm{H} & 0.27545 & -1.70285 & 5.17074 \\ \mathrm{C} & -6.23182 & -2.03680 & 2.03566 \\ \mathrm{H} & -6.07217 & -3.05075 & 2.41002 \\ \mathrm{H} & -6.66275 & -1.42565 & 2.83689 \\ \mathrm{H} & -6.96531 & -2.06916 & 1.22744\end{array}$

\section{TS8-E}

M06-2X/6-31G(d) Energy = -3926.924332

M06-2X/6-31G(d) Free Energy = -3925.518323

Number of Imaginary Frequencies $=1(-974.59)$

$\begin{array}{lrrr}\text { M06-2X } / 6-31 G(d) & \text { Geometry } & \\ \text { C } & -3.19331 & 2.24048 & 0.25638 \\ \text { C } & -4.31709 & 1.95389 & 1.09550 \\ \mathrm{C} & -3.23758 & 3.04492 & -0.86123 \\ \mathrm{C} & -4.05027 & 1.28416 & 2.40232 \\ \mathrm{C} & -5.54310 & 2.84691 & 1.01553 \\ \mathrm{C} & -2.86863 & 0.55539 & 2.62148 \\ \mathrm{C} & -2.66408 & -0.12462 & 3.81819 \\ \mathrm{C} & -3.62575 & -0.12754 & 4.82909 \\ \mathrm{C} & -4.79585 & 0.60690 & 4.61559 \\ \mathrm{C} & -5.00497 & 1.29691 & 3.43075 \\ \mathrm{C} & -3.42080 & -0.91539 & 6.09586 \\ \mathrm{~N} & -2.21217 & 3.27864 & -1.69536 \\ \mathrm{C} & -2.24581 & 4.44929 & -2.56917 \\ \mathrm{C} & -1.31316 & 4.25498 & -3.75724 \\ \mathrm{O} & -0.01075 & 3.95323 & -3.31519 \\ \mathrm{C} & -0.00547 & 2.70178 & -2.64833 \\ \mathrm{C} & -0.89353 & 2.70528 & -1.41477 \\ \mathrm{H} & -4.14436 & 3.58073 & -1.13276 \\ \mathrm{C} & -5.07800 & -0.20398 & -0.30758 \\ \mathrm{C} & -4.29002 & -1.22456 & 0.38822 \\ \mathrm{C} & -3.00118 & -1.44705 & -0.02683 \\ \mathrm{~N} & -2.56423 & -0.83394 & -1.17470 \\ \mathrm{C} & -3.32150 & -0.05182 & -1.98383 \\ \mathrm{C} & -4.62313 & 0.23349 & -1.61516 \\ \mathrm{C} & -2.65004 & 0.39214 & -3.24700 \\ \mathrm{C} & -1.95086 & -2.28296 & 0.63932 \\ \mathrm{C} & -5.50034 & 1.06895 & -2.47094 \\ \mathrm{C} & -4.96154 & -1.78418 & 1.59552 \\ \mathrm{C} & -6.97694 & 1.12316 & -2.11982 \\ \mathrm{O} & -5.08054 & 1.69763 & -3.42927 \\ \mathrm{C} & -4.35204 & -2.88571 & 2.43696 \\ \mathrm{O} & -6.05809 & -1.34138 & 1.89742 \\ \mathrm{C} & 6.04601 & -1.63938 & -0.79293\end{array}$




\begin{tabular}{|c|c|c|c|}
\hline $\mathrm{C}$ & 4.76386 & -2.24569 & -0.69210 \\
\hline $\mathrm{C}$ & 4.57382 & -3.51952 & -1.29392 \\
\hline $\mathrm{C}$ & 5.66832 & -4.16758 & -1.92400 \\
\hline $\mathrm{C}$ & 6.89846 & -3.56766 & -1.98508 \\
\hline $\mathrm{C}$ & 7.08129 & -2.28246 & -1.42263 \\
\hline $\mathrm{C}$ & 3.65634 & -1.61704 & -0.03112 \\
\hline $\mathrm{C}$ & 2.40798 & -2.19705 & -0.12648 \\
\hline $\mathrm{C}$ & 2.19870 & -3.46468 & -0.74098 \\
\hline $\mathrm{C}$ & 3.28593 & -4.11236 & -1.27074 \\
\hline $\mathrm{C}$ & 3.82341 & -0.35404 & 0.73232 \\
\hline $\mathrm{C}$ & 4.78588 & -0.24241 & 1.79082 \\
\hline $\mathrm{C}$ & 5.00471 & 1.02617 & 2.39378 \\
\hline $\mathrm{C}$ & 4.24181 & 2.13970 & 1.96043 \\
\hline $\mathrm{C}$ & 3.24647 & 2.01673 & 1.02434 \\
\hline $\mathrm{C}$ & 3.03464 & 0.73901 & 0.43305 \\
\hline $\mathrm{C}$ & 5.51907 & -1.35621 & 2.28456 \\
\hline $\mathrm{C}$ & 6.43741 & -1.20433 & 3.29226 \\
\hline $\mathrm{C}$ & 6.67996 & 0.06722 & 3.86308 \\
\hline $\mathrm{C}$ & 5.97333 & 1.15542 & 3.42336 \\
\hline $\mathrm{C}$ & 0.84857 & -4.10652 & -0.75751 \\
\hline $\mathrm{O}$ & 2.06776 & 0.63048 & -0.54216 \\
\hline $\mathrm{O}$ & 1.33419 & -1.58061 & 0.47396 \\
\hline $\mathrm{C}$ & 2.46651 & 3.21070 & 0.58025 \\
\hline $\mathrm{C}$ & 0.38510 & -4.78625 & 0.38175 \\
\hline $\mathrm{C}$ & -0.86045 & -5.41876 & 0.32989 \\
\hline $\mathrm{C}$ & -1.66107 & -5.37739 & -0.80671 \\
\hline $\mathrm{C}$ & -1.18132 & -4.69211 & -1.92370 \\
\hline $\mathrm{C}$ & 0.05860 & -4.05269 & -1.92502 \\
\hline $\mathrm{C}$ & 2.82333 & 3.86248 & -0.61188 \\
\hline $\mathrm{C}$ & 2.10237 & 4.99516 & -1.00557 \\
\hline $\mathrm{C}$ & 1.08008 & 5.52095 & -0.22163 \\
\hline $\mathrm{C}$ & 0.76424 & 4.86864 & 0.97284 \\
\hline $\mathrm{C}$ & 1.41710 & 3.70665 & 1.38063 \\
\hline $\mathrm{P}$ & 0.69544 & -0.22696 & -0.22374 \\
\hline $\mathrm{O}$ & -0.16065 & 0.42499 & 0.80986 \\
\hline $\mathrm{O}$ & 0.12381 & -0.56850 & -1.57528 \\
\hline $\mathrm{C}$ & 1.00649 & 3.01505 & 2.67201 \\
\hline $\mathrm{C}$ & -0.50914 & 3.01189 & 2.87891 \\
\hline $\mathrm{C}$ & 1.69465 & 3.66174 & 3.88158 \\
\hline $\mathrm{C}$ & 0.32219 & 6.78370 & -0.59618 \\
\hline $\mathrm{C}$ & 0.45642 & 7.16438 & -2.07046 \\
\hline $\mathrm{C}$ & 0.76341 & 7.95068 & 0.29830 \\
\hline $\mathrm{C}$ & 4.00190 & 3.40803 & -1.46467 \\
\hline $\mathrm{C}$ & 5.01115 & 4.54922 & -1.64719 \\
\hline $\mathrm{C}$ & 3.56013 & 2.84924 & -2.82265 \\
\hline $\mathrm{C}$ & -3.02644 & -6.03817 & -0.82627 \\
\hline
\end{tabular}




\begin{tabular}{|c|c|c|c|}
\hline $\mathrm{C}$ & -3.04806 & -7.23539 & -1.78359 \\
\hline $\mathrm{C}$ & -4.13373 & -5.04041 & -1.18690 \\
\hline $\mathrm{C}$ & 0.53050 & -3.32158 & -3.17317 \\
\hline $\mathrm{C}$ & -0.62020 & -2.64776 & -3.92662 \\
\hline $\mathrm{C}$ & 1.27263 & -4.27252 & -4.12242 \\
\hline $\mathrm{C}$ & 1.17259 & -4.81704 & 1.68243 \\
\hline $\mathrm{C}$ & 1.39467 & -6.24817 & 2.18354 \\
\hline $\mathrm{C}$ & 0.47825 & -3.95861 & 2.74831 \\
\hline $\mathrm{H}$ & -2.25541 & 1.74176 & 0.47620 \\
\hline $\mathrm{H}$ & -5.39737 & 3.74348 & 1.62832 \\
\hline $\mathrm{H}$ & -6.43487 & 2.32661 & 1.37160 \\
\hline $\mathrm{H}$ & -5.74104 & 3.16414 & -0.01004 \\
\hline $\mathrm{H}$ & -2.06884 & 0.52019 & 1.88649 \\
\hline $\mathrm{H}$ & -1.72776 & -0.66183 & 3.96014 \\
\hline $\mathrm{H}$ & -5.55738 & 0.63578 & 5.39043 \\
\hline $\mathrm{H}$ & -5.93254 & 1.84552 & 3.31345 \\
\hline $\mathrm{H}$ & -3.80170 & -1.93697 & 5.98079 \\
\hline $\mathrm{H}$ & -3.94937 & -0.46073 & 6.93797 \\
\hline $\mathrm{H}$ & -2.36028 & -0.98634 & 6.35170 \\
\hline $\mathrm{H}$ & -1.91767 & 5.33665 & -2.00757 \\
\hline $\mathrm{H}$ & -3.27518 & 4.60232 & -2.90822 \\
\hline $\mathrm{H}$ & -1.69247 & 3.45248 & -4.40982 \\
\hline $\mathrm{H}$ & -1.25647 & 5.18076 & -4.33607 \\
\hline $\mathrm{H}$ & -0.31718 & 1.91628 & -3.35016 \\
\hline $\mathrm{H}$ & 1.01617 & 2.49735 & -2.33000 \\
\hline $\mathrm{H}$ & -0.41497 & 3.26567 & -0.60079 \\
\hline $\mathrm{H}$ & -1.02196 & 1.67376 & -1.08376 \\
\hline $\mathrm{H}$ & -4.88734 & 0.82850 & 0.44384 \\
\hline $\mathrm{H}$ & -6.15135 & -0.30427 & -0.14996 \\
\hline $\mathrm{H}$ & -1.54501 & -0.89295 & -1.39320 \\
\hline $\mathrm{H}$ & -2.70354 & 1.47798 & -3.33407 \\
\hline $\mathrm{H}$ & -1.60926 & 0.06108 & -3.25268 \\
\hline $\mathrm{H}$ & -3.17670 & -0.01493 & -4.11561 \\
\hline $\mathrm{H}$ & -1.11801 & -2.46179 & -0.04470 \\
\hline $\mathrm{H}$ & -1.55671 & -1.75214 & 1.51355 \\
\hline $\mathrm{H}$ & -2.33182 & -3.25282 & 0.95170 \\
\hline $\mathrm{H}$ & -7.13832 & 1.54395 & -1.12195 \\
\hline $\mathrm{H}$ & -7.48312 & 1.74170 & -2.86075 \\
\hline $\mathrm{H}$ & -7.41071 & 0.11762 & -2.11962 \\
\hline $\mathrm{H}$ & -4.20281 & -3.79668 & 1.84652 \\
\hline $\mathrm{H}$ & -5.04901 & -3.09206 & 3.25024 \\
\hline $\mathrm{H}$ & -3.38640 & -2.58562 & 2.85048 \\
\hline $\mathrm{H}$ & 6.19690 & -0.64993 & -0.37524 \\
\hline $\mathrm{H}$ & 5.50376 & -5.14558 & -2.36905 \\
\hline $\mathrm{H}$ & 7.72875 & -4.06677 & -2.47467 \\
\hline $\mathrm{H}$ & 8.04983 & -1.79761 & -1.49557 \\
\hline
\end{tabular}




\begin{tabular}{|c|c|c|c|}
\hline $\mathrm{H}$ & 3.15814 & -5.10547 & -1.69447 \\
\hline $\mathrm{H}$ & 4.45298 & 3.11816 & 2.38487 \\
\hline $\mathrm{H}$ & 5.33568 & -2.33849 & 1.86292 \\
\hline $\mathrm{H}$ & 6.98024 & -2.06982 & 3.65941 \\
\hline $\mathrm{H}$ & 7.41460 & 0.17333 & 4.65509 \\
\hline $\mathrm{H}$ & 6.13237 & 2.13664 & 3.86323 \\
\hline $\mathrm{H}$ & -1.22944 & -5.93890 & 1.21295 \\
\hline $\mathrm{H}$ & -1.79543 & -4.64790 & -2.82012 \\
\hline $\mathrm{H}$ & 2.35637 & 5.47289 & -1.94778 \\
\hline $\mathrm{H}$ & -0.04246 & 5.26775 & 1.58567 \\
\hline $\mathrm{H}$ & 1.32199 & 1.96908 & 2.60154 \\
\hline $\mathrm{H}$ & -1.01955 & 2.65416 & 1.98195 \\
\hline $\mathrm{H}$ & -0.77295 & 2.34633 & 3.70686 \\
\hline $\mathrm{H}$ & -0.89057 & 4.00944 & 3.12630 \\
\hline $\mathrm{H}$ & 1.38150 & 3.16922 & 4.80840 \\
\hline $\mathrm{H}$ & 1.42208 & 4.72146 & 3.95050 \\
\hline $\mathrm{H}$ & 2.78383 & 3.59760 & 3.81425 \\
\hline $\mathrm{H}$ & -0.74112 & 6.59238 & -0.38717 \\
\hline $\mathrm{H}$ & 0.26729 & 6.30452 & -2.72025 \\
\hline $\mathrm{H}$ & -0.24346 & 7.96817 & -2.32066 \\
\hline $\mathrm{H}$ & 1.46622 & 7.53098 & -2.28732 \\
\hline $\mathrm{H}$ & 0.62392 & 7.71720 & 1.35789 \\
\hline $\mathrm{H}$ & 1.82627 & 8.16190 & 0.13797 \\
\hline $\mathrm{H}$ & 0.19433 & 8.85721 & 0.06582 \\
\hline $\mathrm{H}$ & 4.51837 & 2.60389 & -0.93158 \\
\hline $\mathrm{H}$ & 5.31896 & 4.96152 & -0.68133 \\
\hline $\mathrm{H}$ & 5.90285 & 4.18592 & -2.16826 \\
\hline $\mathrm{H}$ & 4.58789 & 5.36500 & -2.24299 \\
\hline $\mathrm{H}$ & 3.01133 & 1.91148 & -2.69643 \\
\hline $\mathrm{H}$ & 2.91728 & 3.56057 & -3.35548 \\
\hline $\mathrm{H}$ & 4.43449 & 2.64585 & -3.45025 \\
\hline $\mathrm{H}$ & -3.22362 & -6.41154 & 0.18770 \\
\hline $\mathrm{H}$ & -2.28182 & -7.96784 & -1.51414 \\
\hline $\mathrm{H}$ & -2.85378 & -6.90827 & -2.81106 \\
\hline $\mathrm{H}$ & -4.02444 & -7.73084 & -1.76585 \\
\hline $\mathrm{H}$ & -4.01423 & -4.67721 & -2.21343 \\
\hline $\mathrm{H}$ & -5.11849 & -5.51349 & -1.11386 \\
\hline $\mathrm{H}$ & -4.12202 & -4.16558 & -0.52724 \\
\hline $\mathrm{H}$ & 1.21545 & -2.53078 & -2.85339 \\
\hline $\mathrm{H}$ & -1.29477 & -2.13778 & -3.23524 \\
\hline $\mathrm{H}$ & -0.22385 & -1.90801 & -4.62899 \\
\hline $\mathrm{H}$ & -1.20608 & -3.37191 & -4.50497 \\
\hline $\mathrm{H}$ & 2.16989 & -4.69178 & -3.66100 \\
\hline $\mathrm{H}$ & 0.61952 & -5.10336 & -4.41391 \\
\hline $\mathrm{H}$ & 1.57576 & -3.74234 & -5.03163 \\
\hline $\mathrm{H}$ & 2.15799 & -4.37829 & 1.49707 \\
\hline
\end{tabular}




$\begin{array}{cccc}\mathrm{H} & 1.88116 & -6.86264 & 1.41999 \\ \mathrm{H} & 2.02791 & -6.24233 & 3.07652 \\ \mathrm{H} & 0.44889 & -6.73063 & 2.45271 \\ \mathrm{H} & 0.40341 & -2.91975 & 2.41353 \\ \mathrm{H} & -0.53196 & -4.33564 & 2.95267 \\ \mathrm{H} & 1.04272 & -3.98094 & 3.68668\end{array}$

\section{TS8-Z}

M06-2X/6-31G(d) Energy = -3926.916223

M06-2X/6-31G(d) Free Energy = -3925.511622

Number of Imaginary Frequencies $=1(-1021.70)$

$\begin{array}{lrrr}\text { M06-2X/6-31G(d) } & \text { Geometry } & \\ \mathrm{C} & 3.52354 & 0.21425 & -0.26183 \\ \mathrm{C} & 4.37197 & -0.48201 & -1.17015 \\ \mathrm{C} & 3.93860 & 0.64662 & 0.98442 \\ \mathrm{C} & 5.86247 & -0.29643 & -1.18935 \\ \mathrm{C} & 3.76198 & -0.73486 & -2.53847 \\ \mathrm{C} & 6.46467 & 0.92135 & -0.86631 \\ \mathrm{C} & 7.84766 & 1.07372 & -0.94803 \\ \mathrm{C} & 8.66706 & 0.02346 & -1.35698 \\ \mathrm{C} & 8.05809 & -1.18932 & -1.70269 \\ \mathrm{C} & 6.68200 & -1.34794 & -1.62812 \\ \mathrm{C} & 10.16453 & 0.17597 & -1.42562 \\ \mathrm{~N} & 3.19278 & 1.25080 & 1.91085 \\ \mathrm{C} & 3.76104 & 1.74097 & 3.16181 \\ \mathrm{C} & 3.57546 & 3.25544 & 3.23803 \\ \mathrm{O} & 2.21478 & 3.59306 & 3.10149 \\ \mathrm{C} & 1.70760 & 3.15911 & 1.84927 \\ \mathrm{C} & 1.79689 & 1.64764 & 1.70880 \\ \mathrm{H} & 4.97745 & 0.50613 & 1.27941 \\ \mathrm{C} & 3.98285 & -2.85209 & -0.00120 \\ \mathrm{C} & 2.81335 & -3.27827 & -0.77315 \\ \mathrm{C} & 1.56732 & -2.90215 & -0.33644 \\ \mathrm{~N} & 1.46009 & -2.29000 & 0.88812 \\ \mathrm{C} & 2.48492 & -2.05116 & 1.74088 \\ \mathrm{C} & 3.77360 & -2.37830 & 1.35415 \\ \mathrm{C} & 2.06864 & -1.50168 & 3.07300 \\ \mathrm{C} & 0.25115 & -3.05581 & -1.03827 \\ \mathrm{C} & 4.93758 & -2.13432 & 2.24413 \\ \mathrm{C} & 3.16291 & -3.88465 & -2.08459 \\ \mathrm{C} & 6.27753 & -2.70606 & 1.82473 \\ \mathrm{O} & 4.85629 & -1.47513 & 3.26965 \\ \mathrm{C} & 2.12378 & -4.32313 & -3.09154 \\ \mathrm{O} & 4.34783 & -3.99523 & -2.37038 \\ \mathrm{C} & -6.21309 & 1.37050 & 1.09237\end{array}$




\begin{tabular}{|c|c|c|c|}
\hline $\mathrm{C}$ & -5.42627 & 0.21064 & 0.85585 \\
\hline $\mathrm{C}$ & -5.86584 & -1.02534 & 1.40118 \\
\hline $\mathrm{C}$ & -7.08843 & -1.07831 & 2.12037 \\
\hline $\mathrm{C}$ & -7.83524 & 0.05345 & 2.31718 \\
\hline $\mathrm{C}$ & -7.38249 & 1.29246 & 1.80535 \\
\hline $\mathrm{C}$ & -4.20615 & 0.23992 & 0.10340 \\
\hline $\mathrm{C}$ & -3.41820 & -0.88874 & 0.05757 \\
\hline $\mathrm{C}$ & -3.84024 & -2.13287 & 0.60696 \\
\hline $\mathrm{C}$ & -5.06562 & -2.18206 & 1.22320 \\
\hline $\mathrm{C}$ & -3.78929 & 1.45150 & -0.64334 \\
\hline $\mathrm{C}$ & -4.66524 & 2.02762 & -1.62197 \\
\hline $\mathrm{C}$ & -4.30675 & 3.26036 & -2.22763 \\
\hline $\mathrm{C}$ & -3.08589 & 3.87149 & -1.85668 \\
\hline $\mathrm{C}$ & -2.19841 & 3.28026 & -0.98948 \\
\hline $\mathrm{C}$ & -2.54897 & 2.02174 & -0.41908 \\
\hline $\mathrm{C}$ & -5.87266 & 1.40163 & -2.04062 \\
\hline $\mathrm{C}$ & -6.68032 & 1.98884 & -2.98071 \\
\hline $\mathrm{C}$ & -6.33516 & 3.23527 & -3.55534 \\
\hline $\mathrm{C}$ & -5.16950 & 3.85275 & -3.18716 \\
\hline $\mathrm{C}$ & -3.02541 & -3.37634 & 0.46278 \\
\hline $\mathrm{O}$ & -1.66921 & 1.42311 & 0.45629 \\
\hline $\mathrm{O}$ & -2.22175 & -0.83032 & -0.62340 \\
\hline $\mathrm{C}$ & -0.96224 & 4.04993 & -0.64205 \\
\hline $\mathrm{C}$ & -3.02158 & -4.06984 & -0.76275 \\
\hline $\mathrm{C}$ & -2.31732 & -5.27086 & -0.85615 \\
\hline $\mathrm{C}$ & -1.61136 & -5.79665 & 0.22511 \\
\hline $\mathrm{C}$ & -1.61461 & -5.08243 & 1.42001 \\
\hline $\mathrm{C}$ & -2.30987 & -3.87881 & 1.56649 \\
\hline $\mathrm{C}$ & 0.19655 & 3.90764 & -1.42466 \\
\hline $\mathrm{C}$ & 1.27267 & 4.76740 & -1.18943 \\
\hline $\mathrm{C}$ & 1.23164 & 5.74964 & -0.20272 \\
\hline $\mathrm{C}$ & 0.07183 & 5.86972 & 0.56224 \\
\hline $\mathrm{C}$ & -1.03006 & 5.03695 & 0.36316 \\
\hline $\mathrm{P}$ & -0.97149 & -0.04068 & 0.11738 \\
\hline $\mathrm{O}$ & 0.12400 & 0.09831 & -0.88639 \\
\hline $\mathrm{O}$ & -0.70535 & -0.70089 & 1.44480 \\
\hline $\mathrm{C}$ & -2.24855 & 5.15312 & 1.26792 \\
\hline $\mathrm{C}$ & -2.52443 & 6.58078 & 1.74583 \\
\hline $\mathrm{C}$ & -2.09275 & 4.20778 & 2.46892 \\
\hline $\mathrm{C}$ & 2.42500 & 6.65802 & 0.02736 \\
\hline $\mathrm{C}$ & 2.74621 & 6.84077 & 1.51501 \\
\hline $\mathrm{C}$ & 2.20697 & 8.01724 & -0.64894 \\
\hline $\mathrm{C}$ & 0.25616 & 2.89052 & -2.55245 \\
\hline $\mathrm{C}$ & 1.64113 & 2.26452 & -2.72225 \\
\hline $\mathrm{C}$ & -0.19381 & 3.52926 & -3.87367 \\
\hline $\mathrm{C}$ & -0.83335 & -7.09301 & 0.10060 \\
\hline
\end{tabular}




\begin{tabular}{|c|c|c|c|}
\hline $\mathrm{C}$ & 0.35714 & -6.92546 & -0.85062 \\
\hline $\mathrm{C}$ & -1.72554 & -8.25551 & -0.34621 \\
\hline $\mathrm{C}$ & -2.28153 & -3.15152 & 2.90295 \\
\hline $\mathrm{C}$ & -0.91771 & -3.26261 & 3.59111 \\
\hline $\mathrm{C}$ & -3.36633 & -3.67958 & 3.85198 \\
\hline $\mathrm{C}$ & -3.74383 & -3.54409 & -1.99396 \\
\hline $\mathrm{C}$ & -4.74460 & -4.56756 & -2.54243 \\
\hline $\mathrm{C}$ & -2.73779 & -3.11942 & -3.07097 \\
\hline $\mathrm{H}$ & 2.46565 & 0.24333 & -0.51964 \\
\hline $\mathrm{H}$ & 4.30918 & -1.50094 & -3.09124 \\
\hline $\mathrm{H}$ & 3.80175 & 0.19952 & -3.11007 \\
\hline $\mathrm{H}$ & 2.70840 & -1.02151 & -2.44438 \\
\hline $\mathrm{H}$ & 5.84437 & 1.76418 & -0.57611 \\
\hline $\mathrm{H}$ & 8.29450 & 2.03203 & -0.69594 \\
\hline $\mathrm{H}$ & 8.67525 & -2.01917 & -2.03853 \\
\hline $\mathrm{H}$ & 6.22610 & -2.29842 & -1.90484 \\
\hline $\mathrm{H}$ & 10.55478 & -0.19104 & -2.37967 \\
\hline $\mathrm{H}$ & 10.65338 & -0.39760 & -0.63070 \\
\hline $\mathrm{H}$ & 10.46260 & 1.22150 & -1.31531 \\
\hline $\mathrm{H}$ & 4.81280 & 1.45037 & 3.22058 \\
\hline $\mathrm{H}$ & 3.22736 & 1.27539 & 3.99974 \\
\hline $\mathrm{H}$ & 3.90605 & 3.63266 & 4.20911 \\
\hline $\mathrm{H}$ & 4.17002 & 3.73888 & 2.44462 \\
\hline $\mathrm{H}$ & 0.66829 & 3.48500 & 1.78367 \\
\hline $\mathrm{H}$ & 2.27593 & 3.63148 & 1.03503 \\
\hline $\mathrm{H}$ & 1.44359 & 1.34051 & 0.72240 \\
\hline $\mathrm{H}$ & 1.17199 & 1.15370 & 2.46213 \\
\hline $\mathrm{H}$ & 4.33858 & -1.77745 & -0.65905 \\
\hline $\mathrm{H}$ & 4.87936 & -3.43824 & -0.19798 \\
\hline $\mathrm{H}$ & 0.54224 & -1.86108 & 1.13668 \\
\hline $\mathrm{H}$ & 2.73982 & -0.70794 & 3.38569 \\
\hline $\mathrm{H}$ & 1.03567 & -1.15034 & 3.02435 \\
\hline $\mathrm{H}$ & 2.14552 & -2.29172 & 3.82905 \\
\hline $\mathrm{H}$ & -0.56732 & -2.93109 & -0.32500 \\
\hline $\mathrm{H}$ & 0.14543 & -2.27029 & -1.79470 \\
\hline $\mathrm{H}$ & 0.13722 & -4.03421 & -1.50199 \\
\hline $\mathrm{H}$ & 6.99067 & -2.52629 & 2.62908 \\
\hline $\mathrm{H}$ & 6.20760 & -3.77968 & 1.62285 \\
\hline $\mathrm{H}$ & 6.63497 & -2.22029 & 0.90920 \\
\hline $\mathrm{H}$ & 1.49772 & -5.12584 & -2.69232 \\
\hline $\mathrm{H}$ & 2.65472 & -4.68275 & -3.97314 \\
\hline $\mathrm{H}$ & 1.46691 & -3.49430 & -3.37064 \\
\hline $\mathrm{H}$ & -5.87093 & 2.32700 & 0.71169 \\
\hline $\mathrm{H}$ & -7.41204 & -2.03514 & 2.52215 \\
\hline $\mathrm{H}$ & -8.76578 & 0.00644 & 2.87405 \\
\hline $\mathrm{H}$ & -7.96492 & 2.19115 & 1.98318 \\
\hline
\end{tabular}




$\begin{array}{lrrr}\mathrm{H} & -5.43460 & -3.13549 & 1.59250 \\ \mathrm{H} & -2.83880 & 4.84579 & -2.27305 \\ \mathrm{H} & -6.14546 & 0.44013 & -1.62003 \\ \mathrm{H} & -7.59214 & 1.48886 & -3.29244 \\ \mathrm{H} & -6.98826 & 3.68991 & -4.29356 \\ \mathrm{H} & -4.87757 & 4.80169 & -3.62962 \\ \mathrm{H} & -2.31435 & -5.80485 & -1.80545 \\ \mathrm{H} & -1.05801 & -5.48061 & 2.26541 \\ \mathrm{H} & 2.17550 & 4.66545 & -1.78874 \\ \mathrm{H} & 0.02784 & 6.62618 & 1.34082 \\ \mathrm{H} & -3.12310 & 4.82384 & 0.69682 \\ \mathrm{H} & -2.54443 & 7.28877 & 0.91145 \\ \mathrm{H} & -3.49294 & 6.62002 & 2.25377 \\ \mathrm{H} & -1.77039 & 6.92006 & 2.46406 \\ \mathrm{H} & -1.94707 & 3.17177 & 2.14750 \\ \mathrm{H} & -1.22468 & 4.50498 & 3.07070 \\ \mathrm{H} & -2.97992 & 4.24912 & 3.11004 \\ \mathrm{H} & 3.29056 & 6.17844 & -0.44950 \\ \mathrm{H} & 1.98939 & 7.46146 & 2.00682 \\ \mathrm{H} & 3.70964 & 7.34649 & 1.63699 \\ \mathrm{H} & 2.77831 & 5.88264 & 2.04487 \\ \mathrm{H} & -3.29656 & -3.17803 & 4.82321 \\ \mathrm{H} & 1.33339 & 8.51771 & -0.21632 \\ \mathrm{H} & 3.07664 & 8.66821 & -0.50886 \\ \mathrm{H} & 2.02974 & 7.89972 & -1.72208 \\ \mathrm{H} & -0.42810 & 2.07397 & -2.30347 \\ \mathrm{H} & 2.04644 & 1.93465 & -1.76213 \\ \mathrm{H} & 1.56574 & 1.38873 & -3.37422 \\ \mathrm{H} & 2.35223 & 2.96293 & -3.18026 \\ \mathrm{H} & -1.22184 & 3.89702 & -3.81444 \\ \mathrm{H} & 0.45701 & 4.37399 & -4.12850 \\ \mathrm{H} & -0.14037 & 2.79898 & -4.68818 \\ \mathrm{H} & -0.43711 & -7.33326 & 1.09540 \\ \mathrm{H} & -0.83150 & -2.65419 & -1.70652\end{array}$




$\begin{array}{llll}\mathrm{H} & -5.46078 & -4.87006 & -1.77240 \\ \mathrm{H} & -5.30114 & -4.14042 & -3.38280 \\ \mathrm{H} & -4.23825 & -5.46898 & -2.90454 \\ \mathrm{H} & -2.09123 & -2.32084 & -2.69623 \\ \mathrm{H} & -2.11089 & -3.96691 & -3.37547 \\ \mathrm{H} & -3.26046 & -2.75105 & -3.96004\end{array}$

\section{Cartesian coordinates of reaction components}<smiles>C/C(=C\C=[N+]1CCOCC1)c1ccc(C)cc1</smiles>

\section{Iminium-1}

$\begin{array}{lccc}\text { M06-2X/def2-TZVP Geometry } & \\ \mathrm{C} & 3.59697 & -1.33745 & -0.55770 \\ \mathrm{C} & 2.34226 & -0.77287 & -0.62957 \\ \mathrm{C} & 2.08460 & 0.48560 & -0.06267 \\ \mathrm{C} & 3.14564 & 1.15044 & 0.56463 \\ \mathrm{C} & 4.39565 & 0.56684 & 0.65272 \\ \mathrm{C} & 4.64667 & -0.68448 & 0.09501 \\ \mathrm{C} & 5.99938 & -1.32220 & 0.18408 \\ \mathrm{C} & 0.75950 & 1.09852 & -0.13185 \\ \mathrm{C} & 0.69555 & 2.58951 & 0.00126 \\ \mathrm{C} & -0.34871 & 0.30476 & -0.27154 \\ \mathrm{C} & -1.65770 & 0.81309 & -0.40077 \\ \mathrm{H} & -1.80241 & 1.88412 & -0.46950 \\ \mathrm{~N} & -2.76340 & 0.12859 & -0.46494 \\ \mathrm{C} & -4.06989 & 0.78276 & -0.62684 \\ \mathrm{C} & -4.99545 & 0.34424 & 0.50192 \\ \mathrm{O} & -5.10286 & -1.05633 & 0.52682 \\ \mathrm{C} & -3.86041 & -1.66618 & 0.76341 \\ \mathrm{C} & -2.87343 & -1.33076 & -0.35220 \\ \mathrm{H} & 3.77798 & -2.29854 & -1.02374 \\ \mathrm{H} & 1.56856 & -1.29262 & -1.17928 \\ \mathrm{H} & 2.99472 & 2.12309 & 1.01306 \\ \mathrm{H} & 5.19461 & 1.09344 & 1.15942 \\ \mathrm{H} & 6.73960 & -0.63328 & 0.58543 \\ \mathrm{H} & 5.96232 & -2.19962 & 0.83309 \\ \mathrm{H} & 6.33345 & -1.65963 & -0.79765 \\ \mathrm{H} & 1.48129 & 3.05404 & -0.59243 \\ \mathrm{H} & -0.25541 & 3.02035 & -0.29294\end{array}$




$\begin{array}{lrrr}\mathrm{H} & 0.87090 & 2.86426 & 1.04460 \\ \mathrm{H} & -0.20901 & -0.76451 & -0.26328 \\ \mathrm{H} & -3.93090 & 1.86212 & -0.63304 \\ \mathrm{H} & -4.48409 & 0.46415 & -1.58597 \\ \mathrm{H} & -5.99301 & 0.74699 & 0.33638 \\ \mathrm{H} & -4.61586 & 0.71769 & 1.46157 \\ \mathrm{H} & -4.02461 & -2.74175 & 0.79195 \\ \mathrm{H} & -3.45121 & -1.34252 & 1.72893 \\ \mathrm{H} & -3.25123 & -1.70736 & -1.30505 \\ \mathrm{H} & -1.90270 & -1.77072 & -0.15101\end{array}$<smiles>CC(=CCN(C)C1=[N+](CCO)CCOCC1)c1ccc(C#N)cc1</smiles>

\section{Iminium-2}

$\begin{array}{lrrr}\text { M06-2X/def2-TZVP Geometry } & \\ \mathrm{C} & 3.41886 & -1.10524 & -0.70174 \\ \mathrm{C} & 2.15168 & -0.56300 & -0.77309 \\ \mathrm{C} & 1.83855 & 0.61988 & -0.09288 \\ \mathrm{C} & 2.83989 & 1.25643 & 0.64845 \\ \mathrm{C} & 4.10450 & 0.70815 & 0.74345 \\ \mathrm{C} & 4.39571 & -0.47548 & 0.06860 \\ \mathrm{C} & 0.48593 & 1.19653 & -0.15921 \\ \mathrm{C} & 0.38071 & 2.68255 & -0.01033 \\ \mathrm{C} & -0.58214 & 0.36190 & -0.30623 \\ \mathrm{C} & -1.91934 & 0.82232 & -0.41077 \\ \mathrm{H} & -2.10458 & 1.88854 & -0.45955 \\ \mathrm{~N} & -2.99138 & 0.09404 & -0.46814 \\ \mathrm{C} & -4.33039 & 0.69315 & -0.58901 \\ \mathrm{C} & -5.20693 & 0.19879 & 0.55719 \\ \mathrm{O} & -5.25191 & -1.20483 & 0.56435 \\ \mathrm{C} & -3.97973 & -1.76235 & 0.76220 \\ \mathrm{C} & -3.03807 & -1.37194 & -0.37534 \\ \mathrm{H} & 3.66368 & -2.00820 & -1.24385 \\ \mathrm{H} & 1.41418 & -1.04077 & -1.40430 \\ \mathrm{H} & 2.63000 & 2.17476 & 1.17924 \\ \mathrm{H} & 4.87091 & 1.19128 & 1.33378 \\ \mathrm{H} & 1.18059 & 3.17304 & -0.56312 \\ \mathrm{H} & -0.56719 & 3.09287 & -0.34321 \\ \mathrm{H} & 0.50320 & 2.94926 & 1.04301 \\ \mathrm{H} & -0.39799 & -0.70104 & -0.31797\end{array}$




$\begin{array}{llll}\mathrm{H} & -4.23796 & 1.77742 & -0.58459 \\ \mathrm{H} & -4.75199 & 0.36602 & -1.54164 \\ \mathrm{H} & -6.22431 & 0.56024 & 0.41969 \\ \mathrm{H} & -4.82129 & 0.57688 & 1.51255 \\ \mathrm{H} & -4.09491 & -2.84445 & 0.78032 \\ \mathrm{H} & -3.55906 & -1.43282 & 1.72075 \\ \mathrm{H} & -2.04549 & -1.77547 & -0.20868 \\ \mathrm{H} & -3.42829 & -1.74645 & -1.32371 \\ \mathrm{~N} & 6.75847 & -1.50312 & 0.23467 \\ \mathrm{C} & 5.71014 & -1.04486 & 0.15882\end{array}$<smiles>CC(=CC=[N+]1CCOCC1)c1ccc([N+](=O)[O-])cc1</smiles>

Iminium-3

$\begin{array}{lccc}\text { M06-2X/def2-TZVP Geometry } & \\ \mathrm{C} & 3.02725 & -0.95854 & -0.71641 \\ \mathrm{C} & 1.74510 & -0.44873 & -0.79815 \\ \mathrm{C} & 1.40264 & 0.73637 & -0.13736 \\ \mathrm{C} & 2.38182 & 1.41419 & 0.59623 \\ \mathrm{C} & 3.66283 & 0.90239 & 0.70387 \\ \mathrm{C} & 3.95713 & -0.27574 & 0.04503 \\ \mathrm{C} & 0.03263 & 1.27494 & -0.22107 \\ \mathrm{C} & -0.10782 & 2.76332 & -0.15057 \\ \mathrm{C} & -1.00985 & 0.40374 & -0.31777 \\ \mathrm{C} & -2.36172 & 0.81992 & -0.43646 \\ \mathrm{H} & -2.57770 & 1.87736 & -0.53102 \\ \mathrm{~N} & -3.41098 & 0.05889 & -0.45766 \\ \mathrm{C} & -4.76756 & 0.61309 & -0.59955 \\ \mathrm{C} & -5.62868 & 0.13828 & 0.56642 \\ \mathrm{O} & -5.63251 & -1.26459 & 0.62824 \\ \mathrm{C} & -4.34482 & -1.77658 & 0.84649 \\ \mathrm{C} & -3.41443 & -1.40335 & -0.30610 \\ \mathrm{H} & 3.31661 & -1.86165 & -1.23407 \\ \mathrm{H} & 1.01976 & -0.95488 & -1.42105 \\ \mathrm{H} & 2.14445 & 2.33529 & 1.11018 \\ \mathrm{H} & 4.42898 & 1.39948 & 1.28130 \\ \mathrm{H} & -1.07049 & 3.13333 & -0.48826 \\ \mathrm{H} & 0.02619 & 3.09020 & 0.88420 \\ \mathrm{H} & 0.67212 & 3.24066 & -0.74245 \\ \mathrm{H} & -0.79365 & -0.65274 & -0.27996 \\ \mathrm{H} & -4.70700 & 1.69897 & -0.63777\end{array}$




$\begin{array}{lrrr}\mathrm{H} & -5.17929 & 0.23685 & -1.53818 \\ \mathrm{H} & -6.65629 & 0.46393 & 0.41574 \\ \mathrm{H} & -5.25446 & 0.56451 & 1.50590 \\ \mathrm{H} & -4.42804 & -2.86017 & 0.90601 \\ \mathrm{H} & -3.93426 & -1.39927 & 1.79162 \\ \mathrm{H} & -2.41037 & -1.77038 & -0.12449 \\ \mathrm{H} & -3.79314 & -1.82550 & -1.23900 \\ \mathrm{~N} & 5.33048 & -0.82509 & 0.14955 \\ \mathrm{O} & 6.11608 & -0.20753 & 0.82439 \\ \mathrm{O} & 5.55555 & -1.84943 & -0.44633\end{array}$<smiles></smiles>

Iminium-4

$\begin{array}{lccc}\text { M06-2X/def2-TZVP Geometry } & \\ \mathrm{C} & -2.57840 & -0.82531 & -0.68937 \\ \mathrm{C} & -1.28026 & -0.35925 & -0.73387 \\ \mathrm{C} & -0.91612 & 0.83527 & -0.09737 \\ \mathrm{C} & -1.91083 & 1.55731 & 0.57462 \\ \mathrm{C} & -3.20824 & 1.08751 & 0.64545 \\ \mathrm{C} & -3.53809 & -0.10443 & 0.01280 \\ \mathrm{C} & 0.46198 & 1.33005 & -0.14036 \\ \mathrm{C} & 0.65526 & 2.80599 & 0.02608 \\ \mathrm{C} & 1.49081 & 0.44033 & -0.28559 \\ \mathrm{C} & 2.84532 & 0.82820 & -0.39226 \\ \mathrm{H} & 3.08774 & 1.88250 & -0.44339 \\ \mathrm{~N} & 3.88146 & 0.04513 & -0.45421 \\ \mathrm{C} & 5.24571 & 0.57673 & -0.59415 \\ \mathrm{C} & 6.11628 & 0.03790 & 0.53543 \\ \mathrm{O} & 6.09186 & -1.36655 & 0.54046 \\ \mathrm{C} & 4.79613 & -1.85999 & 0.75852 \\ \mathrm{C} & 3.85446 & -1.42002 & -0.36028 \\ \mathrm{H} & -2.85414 & -1.73564 & -1.20298 \\ \mathrm{H} & -0.55482 & -0.91119 & -1.31684 \\ \mathrm{H} & -1.67216 & 2.48550 & 1.07563 \\ \mathrm{H} & -3.96439 & 1.64112 & 1.18424 \\ \mathrm{H} & 1.63999 & 3.15865 & -0.26150 \\ \mathrm{H} & -0.08803 & 3.35040 & -0.55442 \\ \mathrm{H} & 0.50667 & 3.07168 & 1.07609 \\ \mathrm{H} & 1.25287 & -0.61169 & -0.30029 \\ \mathrm{H} & 5.63742 & 0.23332 & -1.55396\end{array}$




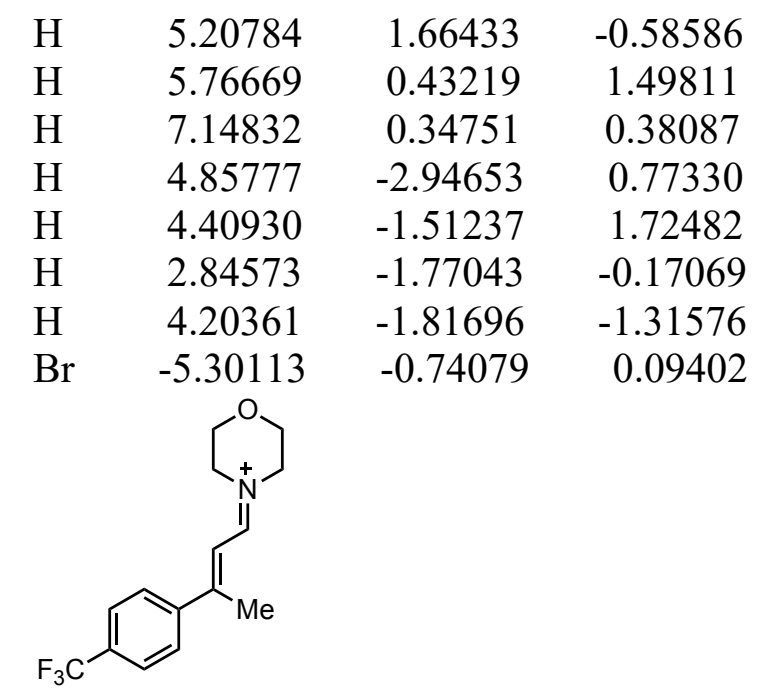

Iminium-5

$\begin{array}{lccc}\text { M06-2X/def2-TZVP Geometry } & \\ \mathrm{C} & -2.65476 & -0.78908 & -0.77326 \\ \mathrm{C} & -1.35557 & -0.31819 & -0.81694 \\ \mathrm{C} & -0.98804 & 0.83093 & -0.10889 \\ \mathrm{C} & -1.96326 & 1.50753 & 0.63178 \\ \mathrm{C} & -3.25798 & 1.02627 & 0.69439 \\ \mathrm{C} & -3.59958 & -0.12034 & -0.00878 \\ \mathrm{C} & 0.39421 & 1.33469 & -0.15344 \\ \mathrm{C} & 0.57601 & 2.81134 & 0.01024 \\ \mathrm{C} & 1.41782 & 0.44506 & -0.29815 \\ \mathrm{C} & 2.77635 & 0.83527 & -0.39981 \\ \mathrm{H} & 3.01587 & 1.89049 & -0.45016 \\ \mathrm{~N} & 3.81072 & 0.05382 & -0.45716 \\ \mathrm{C} & 5.17651 & 0.58626 & -0.58929 \\ \mathrm{C} & 6.03868 & 0.05060 & 0.54863 \\ \mathrm{O} & 6.01519 & -1.35348 & 0.55619 \\ \mathrm{C} & 4.71887 & -1.84774 & 0.76658 \\ \mathrm{C} & 3.78478 & -1.41217 & -0.36082 \\ \mathrm{H} & -2.93889 & -1.66347 & -1.34276 \\ \mathrm{H} & -0.63636 & -0.82177 & -1.44920 \\ \mathrm{H} & -1.71106 & 2.40280 & 1.18321 \\ \mathrm{H} & -4.00617 & 1.54517 & 1.27878 \\ \mathrm{H} & -0.18288 & 3.34719 & -0.55814 \\ \mathrm{H} & 0.43860 & 3.07530 & 1.06241 \\ \mathrm{H} & 1.55310 & 3.17416 & -0.29153 \\ \mathrm{H} & 1.17700 & -0.60668 & -0.31800 \\ \mathrm{H} & 5.57372 & 0.23880 & -1.54519 \\ \mathrm{H} & 5.13756 & 1.67380 & -0.58512 \\ \mathrm{H} & 5.68171 & 0.44717 & 1.50761 \\ \mathrm{H} & 7.07133 & 0.36131 & 0.40064\end{array}$




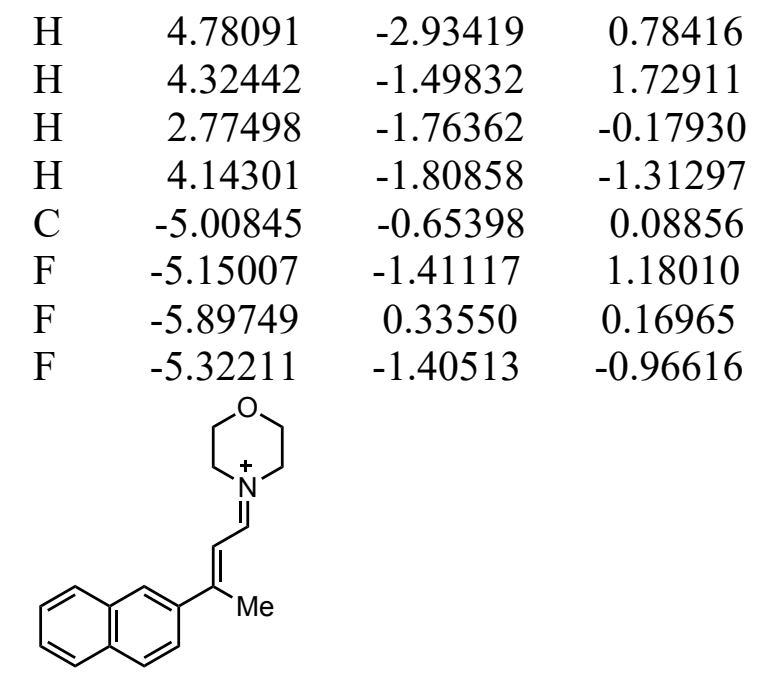

\section{Iminium-6}

M06-2X/def2-TZVP Geometry

$\begin{array}{lrrr}\mathrm{C} & -2.37091 & 1.02850 & 0.15444 \\ \mathrm{C} & -1.26958 & 0.35022 & -0.33245 \\ \mathrm{C} & -1.44466 & -0.98772 & -0.79624 \\ \mathrm{C} & -2.66396 & -1.58763 & -0.74925 \\ \mathrm{C} & 0.03873 & 0.99968 & -0.36009 \\ \mathrm{C} & 0.05968 & 2.49828 & -0.32950 \\ \mathrm{C} & 1.17469 & 0.23212 & -0.37509 \\ \mathrm{C} & 2.47511 & 0.76975 & -0.46061 \\ \mathrm{H} & 2.59601 & 1.83593 & -0.60599 \\ \mathrm{~N} & 3.60122 & 0.11799 & -0.40542 \\ \mathrm{C} & 4.89420 & 0.79878 & -0.56744 \\ \mathrm{C} & 5.79330 & 0.46989 & 0.61765 \\ \mathrm{O} & 5.93967 & -0.92136 & 0.74472 \\ \mathrm{C} & 4.70734 & -1.54891 & 0.98844 \\ \mathrm{C} & 3.74428 & -1.32441 & -0.17506 \\ \mathrm{H} & -2.27952 & 2.04529 & 0.51470 \\ \mathrm{H} & -0.61640 & -1.51790 & -1.24590 \\ \mathrm{H} & -2.79008 & -2.59349 & -1.13036 \\ \mathrm{H} & -0.20809 & 2.84299 & 0.67210 \\ \mathrm{H} & 1.02355 & 2.93212 & -0.57212 \\ \mathrm{H} & -0.67930 & 2.89888 & -1.02146 \\ \mathrm{H} & 1.06419 & -0.83846 & -0.30676 \\ \mathrm{H} & 5.35044 & 0.42763 & -1.48798 \\ \mathrm{H} & 4.72499 & 1.87038 & -0.65486 \\ \mathrm{H} & 5.37238 & 0.89744 & 1.53667 \\ \mathrm{H} & 6.78383 & 0.89075 & 0.45490 \\ \mathrm{H} & 4.89928 & -2.61463 & 1.09887 \\ \mathrm{H} & 4.26088 & -1.17048 & 1.91677 \\ \mathrm{H} & 2.77880 & -1.77119 & 0.03717 \\ \mathrm{H} & 4.15554 & -1.76442 & -1.08625\end{array}$




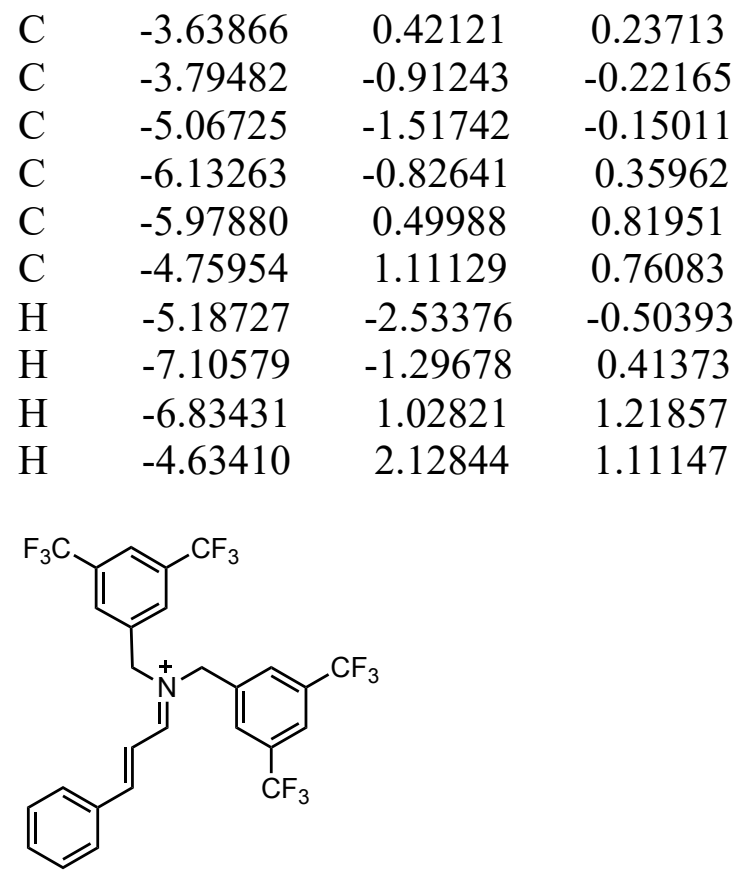

Iminium-7

\begin{tabular}{lccc}
\multicolumn{4}{c}{ M06-2X/def2-TZVP Geometry } \\
C & -6.07525 & -0.38820 & -1.27331 \\
$\mathrm{C}$ & -5.98088 & -0.99012 & -0.00782 \\
$\mathrm{C}$ & -7.11984 & -1.04856 & 0.80863 \\
$\mathrm{C}$ & -8.32215 & -0.52151 & 0.37578 \\
$\mathrm{C}$ & -4.75811 & -1.54909 & 0.49950 \\
$\mathrm{C}$ & -3.54505 & -1.59298 & -0.11646 \\
$\mathrm{C}$ & -2.46414 & -2.18051 & 0.57811 \\
$\mathrm{H}$ & -2.66065 & -2.56042 & 1.57691 \\
$\mathrm{~N}$ & -1.23874 & -2.32211 & 0.16484 \\
$\mathrm{C}$ & -0.21733 & -2.96566 & 1.02315 \\
$\mathrm{C}$ & -0.78518 & -1.88627 & -1.16727 \\
$\mathrm{H}$ & -5.21055 & -0.33005 & -1.92136 \\
$\mathrm{H}$ & -7.04938 & -1.51027 & 1.78638 \\
$\mathrm{H}$ & -9.19651 & -0.56810 & 1.01032 \\
$\mathrm{H}$ & -3.40097 & -1.17191 & -1.10117 \\
$\mathrm{H}$ & 0.03442 & -3.92479 & 0.56666 \\
$\mathrm{H}$ & -0.02816 & -2.60027 & -1.49276 \\
$\mathrm{C}$ & -7.27560 & 0.13653 & -1.70125 \\
$\mathrm{C}$ & -8.39880 & 0.07020 & -0.87808 \\
$\mathrm{H}$ & -9.33830 & 0.48400 & -1.22115 \\
$\mathrm{H}$ & -7.34794 & 0.60020 & -2.67566 \\
$\mathrm{H}$ & -4.82648 & -1.98043 & 1.49590 \\
$\mathrm{H}$ & -1.62437 & -1.97042 & -1.85635 \\
$\mathrm{H}$ & -0.67645 & -3.15355 & 1.99293 \\
$\mathrm{C}$ & 0.95528 & -0.91138 & 1.86795
\end{tabular}




$\begin{array}{lrrr}\text { C } & 1.01254 & -2.10606 & 1.15183 \\ \text { C } & -0.28640 & 1.82070 & -0.50211 \\ \text { C } & -0.85731 & 0.55789 & -0.53110 \\ \text { C } & -0.20166 & -0.48995 & -1.16052 \\ \text { C } & 1.02375 & -0.25491 & -1.77278 \\ \text { C } & 3.22708 & -0.41441 & 1.23176 \\ \text { C } & 2.05463 & -0.07698 & 1.90309 \\ \text { C } & 0.93434 & 2.06240 & -1.10624 \\ \text { C } & 1.58008 & 1.01375 & -1.74438 \\ \text { H } & 1.55800 & -1.06146 & -2.26230 \\ \text { C } & 2.94403 & 1.23850 & -2.34941 \\ \text { C } & -1.02410 & 2.90759 & 0.23612 \\ \text { H } & -1.80691 & 0.40641 & -0.03064 \\ \text { H } & 0.04852 & -0.62181 & 2.38742 \\ \text { H } & 4.08402 & 0.24650 & 1.25471 \\ \text { C } & 2.18061 & -2.45588 & 0.49904 \\ \text { C } & 3.28013 & -1.60450 & 0.53449 \\ \text { C } & 4.50151 & -1.98590 & -0.26297 \\ \text { F } & 4.89133 & -3.23057 & 0.01888 \\ \text { H } & 1.38191 & 3.04660 & -1.07079 \\ \text { F } & -2.24030 & 3.10215 & -0.28922 \\ \text { F } & -1.20920 & 2.56091 & 1.51722 \\ \text { F } & -0.37665 & 4.06431 & 0.21336 \\ \text { F } & 3.09441 & 2.49196 & -2.76618 \\ \text { F } & 3.90519 & 1.00066 & -1.44372 \\ \text { F } & 3.16323 & 0.42640 & -3.38164 \\ \text { F } & 5.52243 & -1.16980 & -0.04000 \\ \text { F } & 4.22361 & -1.95151 & -1.57577 \\ \text { H } & 2.24478 & -3.38664 & -0.05493 \\ \text { C } & 1.99630 & 1.23656 & 2.64357 \\ \text { F } & 3.07584 & 1.41414 & 3.40015 \\ \text { F } & 1.94030 & 2.26443 & 1.78397 \\ \text { F } & 0.92261 & 1.31398 & 3.42807\end{array}$<smiles>FC(F)(F)c1cc(C[N+](C/C=C/c2ccc3ccccc3c2)(Cc2cc(C(F)(F)F)cc(C(F)(F)F)c2)Cc2cc(C(F)(F)F)cc(C(F)(F)F)c2)cc(C(F)(F)F)c1</smiles>

Iminium-8 


\begin{tabular}{|c|c|c|c|}
\hline \multicolumn{4}{|c|}{ M06-2X/def2-TZVP Geometry } \\
\hline $\mathrm{C}$ & -5.25708 & -0.38303 & -1.31344 \\
\hline $\mathrm{C}$ & -5.16054 & -1.02441 & -0.04168 \\
\hline $\mathrm{C}$ & -6.29061 & -1.12182 & 0.75574 \\
\hline $\mathrm{C}$ & -3.94223 & -1.57743 & 0.46001 \\
\hline $\mathrm{C}$ & -2.72073 & -1.58432 & -0.15109 \\
\hline $\mathrm{C}$ & -1.63946 & -2.18509 & 0.52179 \\
\hline $\mathrm{H}$ & -1.83299 & -2.60267 & 1.50595 \\
\hline $\mathrm{N}$ & -0.40958 & -2.30495 & 0.10501 \\
\hline $\mathrm{C}$ & 0.61074 & -2.98118 & 0.93632 \\
\hline $\mathrm{C}$ & 0.03954 & -1.82238 & -1.21102 \\
\hline $\mathrm{H}$ & -4.38584 & -0.29897 & -1.94876 \\
\hline $\mathrm{H}$ & -6.22316 & -1.60723 & 1.72373 \\
\hline $\mathrm{H}$ & -2.58009 & -1.12730 & -1.12000 \\
\hline $\mathrm{H}$ & 0.84953 & -3.93135 & 0.45439 \\
\hline $\mathrm{H}$ & 0.79756 & -2.52205 & -1.56424 \\
\hline $\mathrm{C}$ & -6.44330 & 0.12467 & -1.73341 \\
\hline $\mathrm{H}$ & -6.51931 & 0.61127 & -2.69794 \\
\hline $\mathrm{H}$ & -4.01125 & -2.04098 & 1.44162 \\
\hline $\mathrm{H}$ & -0.80093 & -1.88400 & -1.90104 \\
\hline $\mathrm{H}$ & 0.15844 & -3.18910 & 1.90525 \\
\hline $\mathrm{C}$ & 1.82029 & -0.96996 & 1.83460 \\
\hline $\mathrm{C}$ & 1.85203 & -2.14047 & 1.07753 \\
\hline $\mathrm{C}$ & 2.39498 & 1.10277 & -1.69908 \\
\hline $\mathrm{C}$ & 1.83943 & -0.16451 & -1.77297 \\
\hline $\mathrm{C}$ & 0.62020 & -0.42556 & -1.15844 \\
\hline $\mathrm{C}$ & -0.02970 & 0.59514 & -0.48034 \\
\hline $\mathrm{C}$ & 4.08814 & -0.47796 & 1.17974 \\
\hline $\mathrm{C}$ & 2.93042 & -0.15070 & 1.88131 \\
\hline $\mathrm{C}$ & 1.75539 & 2.12360 & -1.01168 \\
\hline $\mathrm{C}$ & 0.54089 & 1.85661 & -0.40593 \\
\hline $\mathrm{H}$ & -0.97439 & 0.42148 & 0.02225 \\
\hline $\mathrm{C}$ & -0.18564 & 2.91060 & 0.38833 \\
\hline $\mathrm{C}$ & 3.75324 & 1.35494 & -2.30536 \\
\hline $\mathrm{H}$ & 2.37087 & -0.95078 & -2.29737 \\
\hline $\mathrm{H}$ & 0.92515 & -0.68833 & 2.37792 \\
\hline $\mathrm{H}$ & 4.95308 & 0.17199 & 1.21124 \\
\hline $\mathrm{C}$ & 3.00605 & -2.48123 & 0.39589 \\
\hline $\mathrm{C}$ & 4.11628 & -1.64428 & 0.44263 \\
\hline $\mathrm{C}$ & 5.32064 & -2.01442 & -0.38476 \\
\hline $\mathrm{F}$ & 6.34834 & -1.20489 & -0.16790 \\
\hline $\mathrm{H}$ & 2.20312 & 3.10573 & -0.94015 \\
\hline $\mathrm{F}$ & 3.97427 & 0.57204 & -3.35954 \\
\hline $\mathrm{F}$ & 3.89096 & 2.62022 & -2.69074 \\
\hline $\mathrm{F}$ & 4.72213 & 1.10262 & -1.41156 \\
\hline $\mathrm{F}$ & 0.44659 & 4.07643 & 0.38000 \\
\hline
\end{tabular}




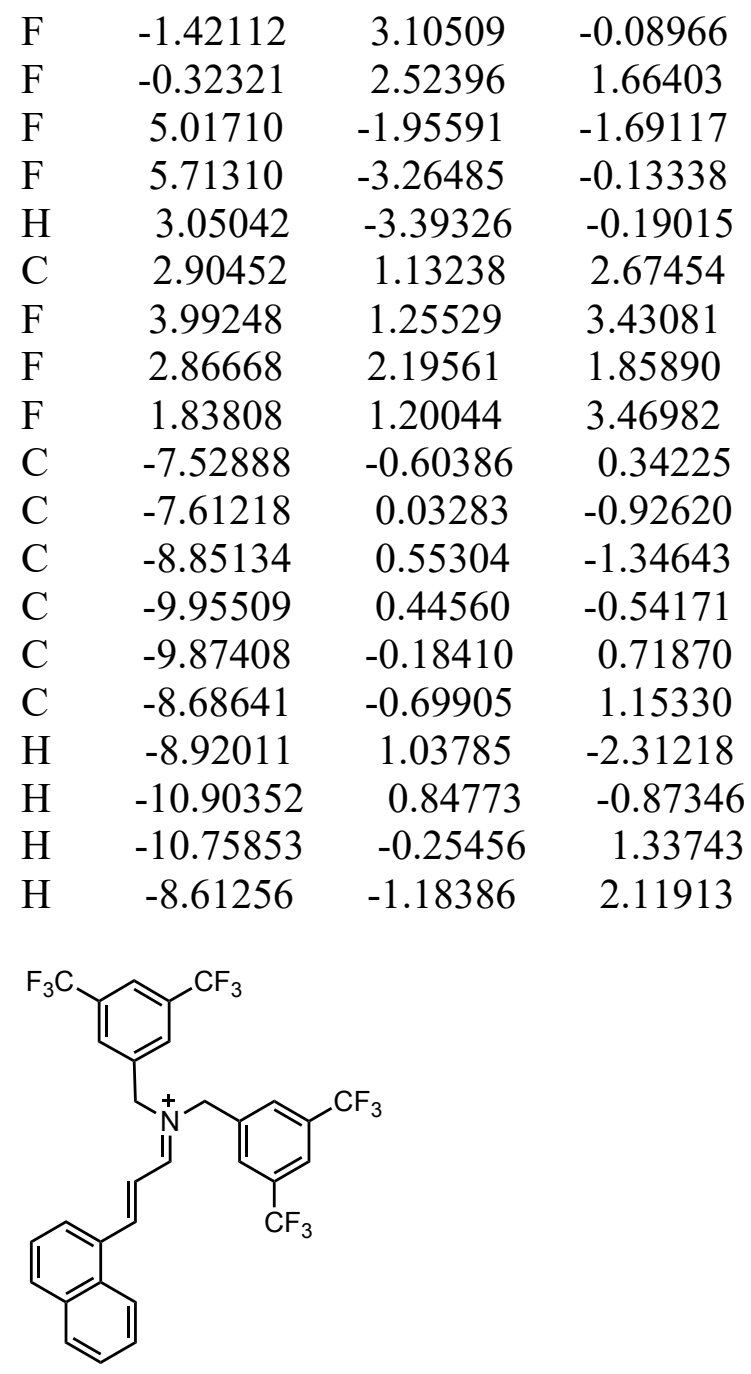

Iminium-9

\begin{tabular}{lccc}
\multicolumn{4}{l}{ M06-2X/def2-TZVP Geometry } \\
C & -5.11545 & 0.79387 & -1.35751 \\
$\mathrm{C}$ & -5.30702 & -0.31280 & -0.53864 \\
$\mathrm{C}$ & -4.18063 & -1.08697 & -0.11138 \\
$\mathrm{C}$ & -2.92313 & -1.08754 & -0.64563 \\
$\mathrm{C}$ & -1.94258 & -1.89549 & -0.03839 \\
$\mathrm{H}$ & -2.23209 & -2.45222 & 0.84822 \\
$\mathrm{~N}$ & -0.70479 & -2.06367 & -0.41360 \\
$\mathrm{C}$ & 0.20287 & -2.95498 & 0.34138 \\
$\mathrm{C}$ & -0.13582 & -1.42454 & -1.61025 \\
$\mathrm{H}$ & -4.11597 & 1.06162 & -1.67502 \\
$\mathrm{H}$ & -2.68035 & -0.49154 & -1.51356 \\
$\mathrm{H}$ & 0.40504 & -3.82682 & -0.28406 \\
$\mathrm{H}$ & 0.57612 & -2.13163 & -2.03672 \\
$\mathrm{C}$ & -6.17629 & 1.61333 & -1.73951
\end{tabular}




\begin{tabular}{|c|c|c|c|}
\hline $\mathrm{H}$ & -5.99331 & 2.47718 & -2.36319 \\
\hline $\mathrm{H}$ & -4.33862 & -1.74483 & 0.73716 \\
\hline $\mathrm{H}$ & -0.93407 & -1.29342 & -2.33953 \\
\hline $\mathrm{H}$ & -0.32892 & -3.28536 & 1.23277 \\
\hline $\mathrm{C}$ & 2.66706 & -2.59163 & 0.05138 \\
\hline $\mathrm{C}$ & 1.49019 & -2.25719 & 0.69603 \\
\hline $\mathrm{C}$ & 0.65499 & 2.02259 & -0.21902 \\
\hline $\mathrm{C}$ & -0.02605 & 0.85058 & -0.51294 \\
\hline $\mathrm{C}$ & 0.56649 & -0.11886 & -1.30786 \\
\hline $\mathrm{C}$ & 1.84140 & 0.10342 & -1.81445 \\
\hline $\mathrm{C}$ & 3.83401 & -0.83948 & 1.22168 \\
\hline $\mathrm{C}$ & 3.83196 & -1.87675 & 0.31120 \\
\hline $\mathrm{C}$ & 1.92452 & 2.25061 & -0.71794 \\
\hline $\mathrm{C}$ & 2.50850 & 1.28131 & -1.52012 \\
\hline $\mathrm{H}$ & 2.32907 & -0.64638 & -2.42675 \\
\hline $\mathrm{C}$ & 3.92245 & 1.47781 & -2.00703 \\
\hline $\mathrm{C}$ & -0.02052 & 3.01989 & 0.68558 \\
\hline $\mathrm{H}$ & -1.01014 & 0.69800 & -0.08375 \\
\hline $\mathrm{H}$ & 2.69005 & -3.40361 & -0.66807 \\
\hline $\mathrm{H}$ & 4.74127 & -0.28313 & 1.41920 \\
\hline $\mathrm{C}$ & 1.48756 & -1.22011 & 1.62725 \\
\hline $\mathrm{C}$ & 2.65040 & -0.52097 & 1.88303 \\
\hline $\mathrm{C}$ & 2.65376 & 0.62345 & 2.86653 \\
\hline $\mathrm{F}$ & 1.56389 & 0.61901 & 3.63294 \\
\hline $\mathrm{H}$ & 2.45716 & 3.15987 & -0.47369 \\
\hline $\mathrm{F}$ & -0.37239 & 2.44199 & 1.84232 \\
\hline $\mathrm{F}$ & 0.75671 & 4.05740 & 0.96405 \\
\hline $\mathrm{F}$ & -1.14745 & 3.48439 & 0.13001 \\
\hline $\mathrm{F}$ & 4.18210 & 2.75830 & -2.25634 \\
\hline $\mathrm{F}$ & 4.79892 & 1.06611 & -1.07794 \\
\hline $\mathrm{F}$ & 4.16232 & 0.78081 & -3.11559 \\
\hline $\mathrm{F}$ & 2.68941 & 1.80173 & 2.22753 \\
\hline $\mathrm{F}$ & 3.71886 & 0.57491 & 3.66185 \\
\hline $\mathrm{H}$ & 0.57485 & -0.94699 & 2.14496 \\
\hline $\mathrm{C}$ & 5.07051 & -2.23207 & -0.47112 \\
\hline $\mathrm{F}$ & 6.13621 & -1.55852 & -0.06046 \\
\hline $\mathrm{F}$ & 5.33983 & -3.53656 & -0.38121 \\
\hline $\mathrm{F}$ & 4.88632 & -1.96098 & -1.77224 \\
\hline $\mathrm{C}$ & -7.44493 & 1.32353 & -1.30182 \\
\hline $\mathrm{H}$ & -8.27646 & 1.95725 & -1.58698 \\
\hline $\mathrm{C}$ & -6.63315 & -0.63804 & -0.08095 \\
\hline $\mathrm{C}$ & -7.70424 & 0.20864 & -0.47599 \\
\hline $\mathrm{C}$ & -9.02329 & -0.07527 & -0.04815 \\
\hline $\mathrm{C}$ & -9.28144 & -1.16198 & 0.73559 \\
\hline $\mathrm{C}$ & -8.22593 & -2.01373 & 1.11409 \\
\hline $\mathrm{C}$ & -6.94017 & -1.76436 & 0.71435 \\
\hline
\end{tabular}




$\begin{array}{lllc}\mathrm{H} & -9.82275 & 0.58524 & -0.36001 \\ \mathrm{H} & -10.29012 & -1.37771 & 1.06071 \\ \mathrm{H} & -8.43663 & -2.88223 & 1.72444 \\ \mathrm{H} & -6.16922 & -2.46243 & 1.00831\end{array}$<smiles>FC(F)(F)c1cc(CN(/C=C/c2ccc(-c3ccccc3)cc2)CN(Cc2cc(C(F)(F)F)cc(C(F)(F)F)c2)Cc2cc(C(F)(F)F)cc(C(F)(F)F)c2)cc(C(F)(F)F)c1</smiles>

\section{Iminium-10}

$\begin{array}{lrrr}\text { M06-2X/def2-TZVP Geometry } & \\ \mathrm{C} & 4.82826 & -0.72333 & -0.59268 \\ \mathrm{C} & 4.58158 & -1.41193 & 0.60922 \\ \mathrm{C} & 3.29131 & -1.89530 & 0.98275 \\ \mathrm{C} & 2.12678 & -1.80901 & 0.27286 \\ \mathrm{C} & 0.96025 & -2.36195 & 0.83311 \\ \mathrm{H} & 1.04194 & -2.80568 & 1.82134 \\ \mathrm{~N} & -0.23099 & -2.40862 & 0.30296 \\ \mathrm{C} & -1.36125 & -3.03568 & 1.02463 \\ \mathrm{C} & -0.52701 & -1.88923 & -1.04036 \\ \mathrm{H} & 4.02031 & -0.51684 & -1.28251 \\ \mathrm{H} & 2.09521 & -1.32159 & -0.69108 \\ \mathrm{H} & -1.01919 & -3.26705 & 2.03255 \\ \mathrm{H} & 0.37224 & -1.98432 & -1.64763 \\ \mathrm{C} & 6.09421 & -0.28864 & -0.89862 \\ \mathrm{H} & 6.26352 & 0.26470 & -1.81248 \\ \mathrm{H} & 3.24480 & -2.39397 & 1.94872 \\ \mathrm{H} & -1.28020 & -2.54651 & -1.47563 \\ \mathrm{H} & -1.59710 & -3.97234 & 0.51539 \\ \mathrm{C} & -3.65165 & -2.40243 & 0.22773 \\ \mathrm{C} & -2.56875 & -2.13529 & 1.04577 \\ \mathrm{C} & -0.94163 & 1.79582 & -0.21326 \\ \mathrm{C} & -0.42896 & 0.50799 & -0.24776 \\ \mathrm{C} & -1.04127 & -0.46590 & -1.02197 \\ \mathrm{C} & -2.16274 & -0.13209 & -1.77200 \\ \mathrm{C} & -4.71796 & -0.36130 & 0.93053 \\ \mathrm{C} & -4.71738 & -1.51089 & 0.16677 \\ \mathrm{C} & -2.05942 & 2.13570 & -0.95396 \\ \mathrm{C} & -2.66059 & 1.16058 & -1.73601\end{array}$




$\begin{array}{lccc}\mathrm{H} & -2.66584 & -0.88109 & -2.37315 \\ \mathrm{C} & -3.92438 & 1.48586 & -2.49217 \\ \mathrm{C} & -0.26667 & 2.79423 & 0.69061 \\ \mathrm{H} & 0.43662 & 0.27480 & 0.36204 \\ \mathrm{H} & -3.67344 & -3.30105 & -0.37994 \\ \mathrm{H} & -5.54794 & 0.33168 & 0.87957 \\ \mathrm{C} & -2.56846 & -0.98271 & 1.83000 \\ \mathrm{C} & -3.63607 & -0.10863 & 1.76980 \\ \mathrm{C} & -3.63902 & 1.15510 & 2.59437 \\ \mathrm{~F} & -2.70047 & 1.13004 & 3.53953 \\ \mathrm{H} & -2.46360 & 3.13836 & -0.91429 \\ \mathrm{~F} & -0.82829 & 3.99407 & 0.63075 \\ \mathrm{~F} & -0.31169 & 2.37903 & 1.96423 \\ \mathrm{~F} & 1.02782 & 2.92639 & 0.37483 \\ \mathrm{~F} & -5.00181 & 1.26369 & -1.72327 \\ \mathrm{~F} & -3.96046 & 2.76165 & -2.86523 \\ \mathrm{~F} & -4.05276 & 0.72977 & -3.58087 \\ \mathrm{~F} & -4.81650 & 1.34337 & 3.18494 \\ \mathrm{~F} & -3.40628 & 2.22803 & 1.82454 \\ \mathrm{H} & -1.73014 & -0.75698 & 2.47968 \\ \mathrm{C} & -5.83669 & -1.80794 & -0.79755 \\ \mathrm{~F} & -6.29600 & -3.05037 & -0.63345 \\ \mathrm{~F} & -6.85406 & -0.96792 & -0.66438 \\ \mathrm{~F} & -5.39164 & -1.72087 & -2.06106 \\ \mathrm{C} & 7.17209 & -0.51901 & -0.02555 \\ \mathrm{C} & 5.65793 & -1.63701 & 1.48390 \\ \mathrm{C} & 6.92593 & -1.20101 & 1.17219 \\ \mathrm{H} & 5.48489 & -2.17181 & 2.41040 \\ \mathrm{H} & 7.74610 & -1.41114 & 1.84510 \\ \mathrm{C} & 11.09203 & 0.83349 & -1.00954 \\ \mathrm{C} & 10.23499 & 0.39828 & -2.01153 \\ \mathrm{C} & 8.95893 & -0.03448 & -1.69351 \\ \mathrm{C} & 8.52608 & -0.05121 & -0.36536 \\ \mathrm{C} & 9.39925 & 0.38247 & 0.63504 \\ \mathrm{C} & 10.67002 & 0.82793 & 0.31336 \\ \mathrm{H} & 12.08739 & 1.17629 & -1.25939 \\ \mathrm{H} & 10.56402 & 0.39148 & -3.04219 \\ \mathrm{H} & 8.30623 & -0.39493 & -2.47862 \\ & 9.07028 & 0.40514 & 1.66639 \\ \mathrm{H} & 1.33165 & 1.17636 & 1.09520\end{array}$


<smiles></smiles>

\section{Iminium-11}

$\begin{array}{lccc}\text { M06-2X/def2-TZVP Geometry } & \\ \mathrm{C} & -5.85253 & -0.48708 & -1.08905 \\ \mathrm{C} & -5.70618 & -1.10340 & 0.16778 \\ \mathrm{C} & -4.46662 & -1.64734 & 0.63105 \\ \mathrm{C} & -3.26553 & -1.65759 & -0.01679 \\ \mathrm{C} & -2.15985 & -2.23883 & 0.63518 \\ \mathrm{H} & -2.32301 & -2.64400 & 1.62989 \\ \mathrm{~N} & -0.94093 & -2.35111 & 0.18765 \\ \mathrm{C} & 0.11088 & -2.99792 & 1.00413 \\ \mathrm{C} & -0.53054 & -1.88217 & -1.14580 \\ \mathrm{H} & -5.01091 & -0.40994 & -1.76510 \\ \mathrm{H} & -3.15468 & -1.21358 & -0.99570 \\ \mathrm{H} & 0.36101 & -3.94632 & 0.52462 \\ \mathrm{H} & 0.22696 & -2.57797 & -1.50756 \\ \mathrm{C} & -7.06855 & 0.02432 & -1.47138 \\ \mathrm{H} & -7.17391 & 0.49703 & -2.44028 \\ \mathrm{H} & -4.50044 & -2.09850 & 1.62061 \\ \mathrm{H} & -1.38708 & -1.96389 & -1.81362 \\ \mathrm{H} & -0.31787 & -3.20808 & 1.98322 \\ \mathrm{C} & 2.48681 & -2.45152 & 0.41989 \\ \mathrm{C} & 1.33537 & -2.12776 & 1.11414 \\ \mathrm{C} & 1.77736 & 1.06168 & -1.73363 \\ \mathrm{C} & 1.23716 & -0.21371 & -1.77121 \\ \mathrm{C} & 0.03369 & -0.47796 & -1.12826 \\ \mathrm{C} & -0.61730 & 0.54806 & -0.45925 \\ \mathrm{C} & 3.53400 & -0.41343 & 1.16046 \\ \mathrm{C} & 3.57794 & -1.58871 & 0.43839 \\ \mathrm{C} & 1.13654 & 2.08857 & -1.05646 \\ \mathrm{C} & -0.06329 & 1.81847 & -0.42295 \\ \mathrm{H} & -1.54979 & 0.37251 & 0.06494 \\ \mathrm{C} & -0.79396 & 2.88055 & 0.35672 \\ \mathrm{C} & 3.11965 & 1.31647 & -2.37353 \\ \mathrm{H} & 1.76781 & -1.00337 & -2.29121 \\ \mathrm{H} & 2.54358 & -3.37034 & -0.15438 \\ \mathrm{H} & 4.38455 & 0.25594 & 1.17173 \\ \mathrm{C} & 1.28738 & -0.94730 & 1.85451\end{array}$




$\begin{array}{lccc}\mathrm{C} & 2.37888 & -0.10227 & 1.87353 \\ \mathrm{C} & 2.33347 & 1.19344 & 2.64525 \\ \mathrm{~F} & 3.42365 & 1.35017 & 3.39186 \\ \mathrm{H} & 1.57130 & 3.07828 & -1.01572 \\ \mathrm{~F} & 4.11028 & 1.07817 & -1.50028 \\ \mathrm{~F} & 3.32042 & 0.52445 & -3.42508 \\ \mathrm{~F} & 3.24039 & 2.57862 & -2.77407 \\ \mathrm{~F} & -2.03708 & 3.04854 & -0.11240 \\ \mathrm{~F} & -0.91394 & 2.52051 & 1.64160 \\ \mathrm{~F} & -0.17726 & 4.05377 & 0.31571 \\ \mathrm{~F} & 1.27093 & 1.25480 & 3.44622 \\ \mathrm{~F} & 2.26977 & 2.24151 & 1.81145 \\ \mathrm{H} & 0.39363 & -0.67746 & 2.40601 \\ \mathrm{C} & 4.77732 & -1.94141 & -0.40384 \\ \mathrm{~F} & 5.79592 & -1.11736 & -0.19934 \\ \mathrm{~F} & 5.19025 & -3.18622 & -0.15744 \\ \mathrm{~F} & 4.45695 & -1.88717 & -1.70631 \\ \mathrm{C} & -8.18558 & -0.05319 & -0.62585 \\ \mathrm{C} & -6.82409 & -1.18236 & 1.01091 \\ \mathrm{C} & -8.04222 & -0.66488 & 0.61859 \\ \mathrm{H} & -6.72456 & -1.65330 & 1.98192 \\ \mathrm{H} & -8.89523 & -0.73153 & 1.28151 \\ \mathrm{C} & -9.49753 & 0.51594 & -1.06679 \\ \mathrm{H} & -10.26954 & 0.37613 & -0.31359 \\ \mathrm{H} & -9.39834 & 1.58416 & -1.26872 \\ \mathrm{H} & -9.82552 & 0.04207 & -1.99382\end{array}$<smiles></smiles>

\section{Iminium-12}

\begin{tabular}{lccc}
\multicolumn{4}{l}{ M06-2X/def2-TZVP Geometry } \\
C & -6.87536 & -1.21724 & 1.18849 \\
C & -5.77843 & -1.10145 & 0.32596 \\
C & -4.52399 & -1.65190 & 0.75578 \\
C & -3.33730 & -1.63975 & 0.08664 \\
C & -2.21721 & -2.24287 & 0.69784 \\
N & -1.01147 & -2.34394 & 0.21733
\end{tabular}




\begin{tabular}{|c|c|c|c|}
\hline $\mathrm{C}$ & -0.63284 & -1.83336 & -1.11072 \\
\hline $\mathrm{C}$ & 0.05812 & -3.02274 & 0.98545 \\
\hline $\mathrm{C}$ & -8.10340 & -0.69936 & 0.81802 \\
\hline $\mathrm{C}$ & -0.69047 & 0.57078 & -0.33281 \\
\hline $\mathrm{C}$ & -0.06734 & -0.43017 & -1.06298 \\
\hline $\mathrm{C}$ & 2.39397 & -0.18114 & 1.85018 \\
\hline $\mathrm{C}$ & 1.29398 & -1.01515 & 1.85280 \\
\hline $\mathrm{C}$ & 1.29652 & -2.17076 & 1.07260 \\
\hline $\mathrm{C}$ & 2.41272 & -2.48210 & 0.31781 \\
\hline $\mathrm{C}$ & 1.04093 & 2.13170 & -0.94188 \\
\hline $\mathrm{C}$ & -0.13364 & 1.83934 & -0.27238 \\
\hline $\mathrm{C}$ & 3.51252 & -0.47853 & 1.07538 \\
\hline $\mathrm{C}$ & 3.51285 & -1.63052 & 0.31573 \\
\hline $\mathrm{C}$ & 4.67033 & -1.96935 & -0.58821 \\
\hline $\mathrm{C}$ & 2.39908 & 1.08618 & 2.66880 \\
\hline $\mathrm{C}$ & 1.11121 & -0.14339 & -1.74221 \\
\hline $\mathrm{C}$ & 1.65353 & 1.13002 & -1.68026 \\
\hline $\mathrm{C}$ & 2.97209 & 1.40868 & -2.35832 \\
\hline $\mathrm{F}$ & 3.06761 & 2.67802 & -2.74236 \\
\hline $\mathrm{F}$ & 2.33774 & 2.16459 & 1.87535 \\
\hline $\mathrm{F}$ & 1.35996 & 1.14130 & 3.50043 \\
\hline $\mathrm{F}$ & 3.51207 & 1.19082 & 3.39054 \\
\hline $\mathrm{F}$ & 5.08733 & -3.22111 & -0.38941 \\
\hline $\mathrm{F}$ & 4.28894 & -1.88436 & -1.87272 \\
\hline $\mathrm{F}$ & 5.70157 & -1.15453 & -0.41361 \\
\hline $\mathrm{F}$ & 3.99166 & 1.16720 & -1.51975 \\
\hline $\mathrm{F}$ & 3.14725 & 0.63529 & -3.42793 \\
\hline $\mathrm{C}$ & -0.83272 & 2.87461 & 0.56988 \\
\hline $\mathrm{F}$ & -0.94181 & 2.45304 & 1.83711 \\
\hline $\mathrm{F}$ & -0.19305 & 4.03601 & 0.57759 \\
\hline $\mathrm{F}$ & -2.07828 & 3.08997 & 0.12779 \\
\hline $\mathrm{C}$ & -8.23952 & -0.06881 & -0.40842 \\
\hline $\mathrm{C}$ & -5.93967 & -0.45669 & -0.91279 \\
\hline $\mathrm{C}$ & -7.16132 & 0.06244 & -1.29387 \\
\hline $\mathrm{C}$ & -7.35202 & 0.74368 & -2.61812 \\
\hline $\mathrm{H}$ & -6.75549 & -1.71011 & 2.14562 \\
\hline $\mathrm{H}$ & -4.53963 & -2.13059 & 1.73273 \\
\hline $\mathrm{H}$ & -3.24525 & -1.16790 & -0.88099 \\
\hline $\mathrm{H}$ & -2.35881 & -2.67707 & 1.68355 \\
\hline $\mathrm{H}$ & -1.50535 & -1.89437 & -1.75961 \\
\hline $\mathrm{H}$ & 0.11533 & -2.51749 & -1.51133 \\
\hline $\mathrm{H}$ & 0.27862 & -3.96312 & 0.47659 \\
\hline $\mathrm{H}$ & -0.34173 & -3.24884 & 1.97312 \\
\hline $\mathrm{H}$ & -8.95266 & -0.78378 & 1.48223 \\
\hline $\mathrm{H}$ & -1.60140 & 0.37615 & 0.22173 \\
\hline $\mathrm{H}$ & 0.42810 & -0.75467 & 2.45119 \\
\hline
\end{tabular}




$\begin{array}{lrrc}\mathrm{H} & 2.43470 & -3.38231 & -0.28750 \\ \mathrm{H} & 1.47882 & 3.11913 & -0.88180 \\ \mathrm{H} & 4.36897 & 0.18331 & 1.06916 \\ \mathrm{H} & 1.62278 & -0.91484 & -2.30684 \\ \mathrm{H} & -9.20324 & 0.33624 & -0.69575 \\ \mathrm{H} & -5.09994 & -0.35828 & -1.58991 \\ \mathrm{H} & -8.01801 & 0.15966 & -3.25542 \\ \mathrm{H} & -7.80447 & 1.72672 & -2.48515 \\ \mathrm{H} & -6.40566 & 0.87032 & -3.14060\end{array}$<smiles></smiles>

\section{Iminium-13}

$\begin{array}{lccc}\text { M06-2X/def2-TZVP Geometry } & \\ \mathrm{C} & -5.80282 & 0.07060 & -1.46178 \\ \mathrm{C} & -5.84268 & -0.72448 & -0.30158 \\ \mathrm{C} & -4.65606 & -1.35831 & 0.19790 \\ \mathrm{C} & -3.41641 & -1.37567 & -0.37108 \\ \mathrm{C} & -2.38220 & -2.05498 & 0.30710 \\ \mathrm{~N} & -1.14629 & -2.20438 & -0.07560 \\ \mathrm{C} & -0.63484 & -1.68044 & -1.35305 \\ \mathrm{C} & -0.17875 & -2.95701 & 0.75518 \\ \mathrm{C} & -6.93775 & 0.68300 & -1.94030 \\ \mathrm{C} & 1.23864 & -0.06792 & -1.79060 \\ \mathrm{C} & -0.00471 & -0.31056 & -1.21794 \\ \mathrm{C} & 2.23066 & -0.27245 & 1.88481 \\ \mathrm{C} & 1.08988 & -1.04218 & 1.77544 \\ \mathrm{C} & 1.09113 & -2.17539 & 0.96302 \\ \mathrm{C} & 2.24626 & -2.53173 & 0.29091 \\ \mathrm{C} & 1.21918 & 2.18462 & -0.92549 \\ \mathrm{C} & 1.83775 & 1.17309 & -1.64518 \\ \mathrm{C} & 3.38880 & -0.61202 & 1.19005 \\ \mathrm{C} & 3.38691 & -1.74350 & 0.39976 \\ \mathrm{C} & 4.59388 & -2.12315 & -0.41973 \\ \mathrm{C} & 2.23680 & 0.96960 & 2.74181 \\ \mathrm{C} & -0.63281 & 0.70126 & -0.50711 \\ \mathrm{C} & -0.01785 & 1.93544 & -0.35954 \\ \mathrm{C} & -0.72134 & 2.97665 & 0.47134 \\ \mathrm{~F} & -0.03891 & 4.11097 & 0.54394\end{array}$




\begin{tabular}{|c|c|c|c|}
\hline$F$ & 2.23180 & 2.07337 & 1.98143 \\
\hline $\mathrm{F}$ & 1.16833 & 1.02642 & 3.53551 \\
\hline $\mathrm{F}$ & 3.32362 & 1.02334 & 3.50702 \\
\hline $\mathrm{F}$ & 4.93384 & -3.39752 & -0.21703 \\
\hline $\mathrm{F}$ & 4.31895 & -1.99574 & -1.72778 \\
\hline $\mathrm{F}$ & 5.64615 & -1.36419 & -0.14764 \\
\hline $\mathrm{F}$ & -1.93272 & 3.25261 & -0.02837 \\
\hline $\mathrm{F}$ & -0.91304 & 2.52765 & 1.71959 \\
\hline $\mathrm{C}$ & 3.22153 & 1.40010 & -2.20171 \\
\hline $\mathrm{F}$ & 4.15212 & 1.09179 & -1.28484 \\
\hline $\mathrm{F}$ & 3.45256 & 0.64109 & -3.27066 \\
\hline $\mathrm{F}$ & 3.40972 & 2.67092 & -2.54476 \\
\hline $\mathrm{C}$ & -8.14116 & 0.50627 & -1.26228 \\
\hline $\mathrm{C}$ & -7.06575 & -0.89768 & 0.38957 \\
\hline $\mathrm{C}$ & -8.19761 & -0.27265 & -0.11657 \\
\hline $\mathrm{H}$ & -4.86698 & 0.21951 & -1.98371 \\
\hline $\mathrm{H}$ & -4.76017 & -1.88828 & 1.14013 \\
\hline $\mathrm{H}$ & -3.21866 & -0.87819 & -1.30927 \\
\hline $\mathrm{H}$ & -2.62644 & -2.51197 & 1.26208 \\
\hline $\mathrm{H}$ & -1.45293 & -1.67935 & -2.07202 \\
\hline $\mathrm{H}$ & 0.10804 & -2.39313 & -1.71195 \\
\hline $\mathrm{H}$ & 0.03412 & -3.89568 & 0.23988 \\
\hline $\mathrm{H}$ & -0.66720 & -3.18478 & 1.70177 \\
\hline $\mathrm{H}$ & -6.89611 & 1.29646 & -2.82960 \\
\hline $\mathrm{H}$ & 1.75754 & -0.84909 & -2.33484 \\
\hline $\mathrm{H}$ & 0.19556 & -0.75065 & 2.31487 \\
\hline $\mathrm{H}$ & 2.26841 & -3.41743 & -0.33539 \\
\hline $\mathrm{H}$ & 1.70019 & 3.14495 & -0.79701 \\
\hline $\mathrm{H}$ & 4.27731 & 0.00158 & 1.26646 \\
\hline $\mathrm{H}$ & -1.59444 & 0.54011 & -0.03294 \\
\hline $\mathrm{H}$ & -9.04159 & 0.98195 & -1.62951 \\
\hline $\mathrm{C}$ & -7.17803 & -1.73406 & 1.63440 \\
\hline $\mathrm{H}$ & -9.14247 & -0.39718 & 0.39645 \\
\hline $\mathrm{H}$ & -8.20101 & -1.72274 & 2.00247 \\
\hline $\mathrm{H}$ & -6.90723 & -2.77456 & 1.44616 \\
\hline $\mathrm{H}$ & -6.53772 & -1.35595 & 2.43354 \\
\hline
\end{tabular}

\section{Iminium-14}




\begin{tabular}{|c|c|c|c|}
\hline \multicolumn{4}{|c|}{ M06-2X/def2-TZVP Geometry } \\
\hline $\mathrm{C}$ & -5.29108 & -2.19073 & 1.33540 \\
\hline $\mathrm{C}$ & -4.27019 & -1.84711 & 0.43597 \\
\hline $\mathrm{C}$ & -2.96251 & -2.37800 & 0.65784 \\
\hline $\mathrm{C}$ & -1.83446 & -2.15766 & -0.08054 \\
\hline $\mathrm{C}$ & -0.62764 & -2.73758 & 0.35301 \\
\hline $\mathrm{N}$ & 0.55127 & -2.62321 & -0.19350 \\
\hline $\mathrm{C}$ & 0.79126 & -1.85465 & -1.42536 \\
\hline $\mathrm{C}$ & 1.73381 & -3.28164 & 0.40270 \\
\hline $\mathrm{C}$ & -6.56523 & -1.68576 & 1.18036 \\
\hline $\mathrm{C}$ & 0.48360 & 0.37118 & -0.26614 \\
\hline $\mathrm{C}$ & 1.19006 & -0.41775 & -1.16209 \\
\hline $\mathrm{C}$ & 3.65829 & -0.32569 & 1.75469 \\
\hline $\mathrm{C}$ & 2.69347 & -1.30216 & 1.61018 \\
\hline $\mathrm{C}$ & 2.84421 & -2.29117 & 0.63940 \\
\hline $\mathrm{C}$ & 3.97715 & -2.30188 & -0.15328 \\
\hline $\mathrm{C}$ & 1.98781 & 2.21269 & -0.65423 \\
\hline $\mathrm{C}$ & 0.88588 & 1.67424 & -0.01545 \\
\hline $\mathrm{C}$ & 4.79070 & -0.31757 & 0.94361 \\
\hline $\mathrm{C}$ & 4.94290 & -1.31153 & -0.00147 \\
\hline $\mathrm{C}$ & 6.12214 & -1.32270 & -0.94010 \\
\hline $\mathrm{C}$ & 3.49236 & 0.76977 & 2.77842 \\
\hline $\mathrm{C}$ & 2.29727 & 0.11750 & -1.81051 \\
\hline $\mathrm{C}$ & 2.68591 & 1.42276 & -1.55560 \\
\hline $\mathrm{C}$ & 3.93166 & 1.97161 & -2.20523 \\
\hline $\mathrm{F}$ & 3.83400 & 3.28050 & -2.42217 \\
\hline $\mathrm{F}$ & 4.60294 & 0.93912 & 3.49168 \\
\hline $\mathrm{F}$ & 3.22143 & 1.93971 & 2.18289 \\
\hline $\mathrm{F}$ & 2.49443 & 0.50949 & 3.62201 \\
\hline $\mathrm{F}$ & 5.71775 & -1.05610 & -2.19186 \\
\hline $\mathrm{F}$ & 7.03954 & -0.42497 & -0.60713 \\
\hline $\mathrm{F}$ & 6.70295 & -2.52432 & -0.96802 \\
\hline $\mathrm{F}$ & 4.99762 & 1.77730 & -1.41411 \\
\hline $\mathrm{F}$ & 4.18499 & 1.37519 & -3.36835 \\
\hline $\mathrm{C}$ & 0.10408 & 2.46942 & 0.99755 \\
\hline $\mathrm{F}$ & -1.18004 & 2.57736 & 0.63288 \\
\hline $\mathrm{F}$ & 0.11511 & 1.85645 & 2.18905 \\
\hline $\mathrm{F}$ & 0.58749 & 3.69361 & 1.16118 \\
\hline $\mathrm{C}$ & -6.86917 & -0.81999 & 0.12839 \\
\hline $\mathrm{C}$ & -4.57702 & -0.97919 & -0.62884 \\
\hline $\mathrm{C}$ & -5.84853 & -0.47955 & -0.77370 \\
\hline $\mathrm{H}$ & -5.06960 & -2.85728 & 2.16078 \\
\hline $\mathrm{H}$ & -2.86574 & -3.02142 & 1.53001 \\
\hline $\mathrm{H}$ & -1.85477 & -1.52208 & -0.95417 \\
\hline $\mathrm{H}$ & -0.65967 & -3.34592 & 1.25233 \\
\hline
\end{tabular}




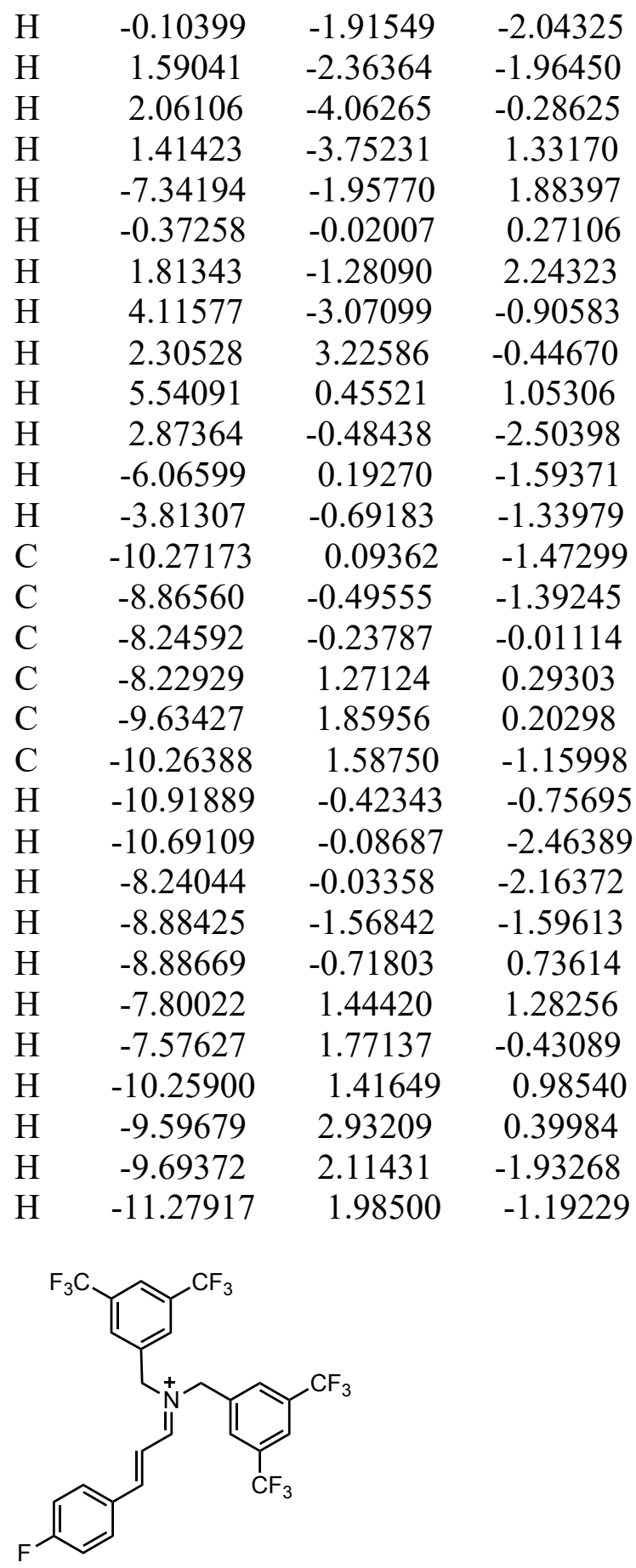

\section{Iminium-15}

$\begin{array}{lccc}\text { M06-2X/def2-TZVP Geometry } & \\ \text { C } & 5.84567 & -0.46681 & -1.11004 \\ \text { C } & 5.71409 & -1.07781 & 0.15021 \\ \text { C } & 4.47732 & -1.62691 & 0.62239 \\ \text { C } & 3.27544 & -1.64793 & -0.01943\end{array}$




\begin{tabular}{|c|c|c|c|}
\hline $\mathrm{C}$ & 2.17283 & -2.23029 & 0.64223 \\
\hline $\mathrm{N}$ & 0.95462 & -2.34914 & 0.19957 \\
\hline $\mathrm{C}$ & 0.53738 & -1.88917 & -1.13573 \\
\hline $\mathrm{C}$ & -0.09428 & -2.99211 & 1.02493 \\
\hline $\mathrm{C}$ & 7.05233 & 0.05313 & -1.51392 \\
\hline $\mathrm{C}$ & -1.23036 & -0.22354 & -1.76707 \\
\hline $\mathrm{C}$ & -0.02630 & -0.48469 & -1.12396 \\
\hline $\mathrm{C}$ & -3.56301 & -1.59085 & 0.45158 \\
\hline $\mathrm{C}$ & -2.47094 & -2.45250 & 0.43780 \\
\hline $\mathrm{C}$ & -1.31987 & -2.12318 & 1.13020 \\
\hline $\mathrm{C}$ & -1.27310 & -0.93875 & 1.86414 \\
\hline $\mathrm{C}$ & -1.12732 & 2.08295 & -1.06577 \\
\hline $\mathrm{C}$ & -1.76967 & 1.05238 & -1.73601 \\
\hline $\mathrm{C}$ & -3.52033 & -0.41149 & 1.16720 \\
\hline $\mathrm{C}$ & -2.36557 & -0.09483 & 1.87841 \\
\hline $\mathrm{C}$ & -2.32103 & 1.20596 & 2.64183 \\
\hline $\mathrm{C}$ & -4.76200 & -1.94933 & -0.38911 \\
\hline $\mathrm{C}$ & 0.62585 & 0.54469 & -0.46148 \\
\hline $\mathrm{C}$ & 0.07300 & 1.81571 & -0.43205 \\
\hline $\mathrm{C}$ & 0.80612 & 2.88101 & 0.34104 \\
\hline $\mathrm{F}$ & 2.05150 & 3.03857 & -0.12626 \\
\hline $\mathrm{F}$ & -5.17264 & -3.19357 & -0.13711 \\
\hline $\mathrm{F}$ & -5.78154 & -1.12583 & -0.18834 \\
\hline $\mathrm{F}$ & -4.44109 & -1.90027 & -1.69169 \\
\hline $\mathrm{F}$ & -2.25719 & 2.24825 & 1.80074 \\
\hline $\mathrm{F}$ & -3.41136 & 1.36710 & 3.38679 \\
\hline $\mathrm{F}$ & -1.25858 & 1.27276 & 3.44244 \\
\hline $\mathrm{F}$ & 0.19526 & 4.05632 & 0.28877 \\
\hline $\mathrm{F}$ & 0.92138 & 2.53033 & 1.62893 \\
\hline $\mathrm{C}$ & -3.11288 & 1.30372 & -2.37582 \\
\hline $\mathrm{F}$ & -3.31278 & 0.50865 & -3.42509 \\
\hline $\mathrm{F}$ & -4.10200 & 1.06563 & -1.50091 \\
\hline $\mathrm{F}$ & -3.23557 & 2.56454 & -2.77905 \\
\hline $\mathrm{C}$ & 8.13776 & -0.03857 & -0.64876 \\
\hline $\mathrm{C}$ & 6.83662 & -1.14941 & 0.99143 \\
\hline $\mathrm{C}$ & 8.05320 & -0.63208 & 0.60059 \\
\hline $\mathrm{H}$ & 4.99843 & -0.39728 & -1.77920 \\
\hline $\mathrm{H}$ & 4.51854 & -2.07170 & 1.61434 \\
\hline $\mathrm{H}$ & 3.15610 & -1.21131 & -1.00066 \\
\hline $\mathrm{H}$ & 2.34144 & -2.62773 & 1.63921 \\
\hline $\mathrm{H}$ & -0.22227 & -2.58741 & -1.48793 \\
\hline $\mathrm{H}$ & 1.39027 & -1.97656 & -1.80746 \\
\hline $\mathrm{H}$ & 0.33803 & -3.19327 & 2.00432 \\
\hline $\mathrm{H}$ & -0.34236 & -3.94460 & 0.55269 \\
\hline $\mathrm{H}$ & 7.18156 & 0.52748 & -2.47682 \\
\hline $\mathrm{H}$ & -1.76194 & -1.01557 & -2.28252 \\
\hline
\end{tabular}




$\begin{array}{lrrr}\mathrm{H} & -2.52697 & -3.37479 & -0.13099 \\ \mathrm{H} & -0.37994 & -0.66485 & 2.41462 \\ \mathrm{H} & -1.56123 & 3.07328 & -1.03066 \\ \mathrm{H} & -4.37173 & 0.25690 & 1.17478 \\ \mathrm{H} & 1.55849 & 0.37234 & 0.06344 \\ \mathrm{H} & 8.92897 & -0.67413 & 1.23290 \\ \mathrm{H} & 6.74284 & -1.61668 & 1.96429 \\ \mathrm{~F} & 9.29614 & 0.46241 & -1.03816\end{array}$<smiles>Fc1cccc(/C=C/C=[N+](Cc2cc(C(F)(F)F)cc(C(F)(F)F)c2)Cc2cc(C(F)(F)F)cc(C(F)(F)F)c2)c1</smiles>

\section{Iminium-16}

$\begin{array}{lrrr}\text { M06-2X/def2-TZVP Geometry } & \\ \mathrm{C} & -6.87580 & -1.16007 & 1.15544 \\ \mathrm{C} & -5.77159 & -1.07951 & 0.29844 \\ \mathrm{C} & -4.52083 & -1.63531 & 0.74847 \\ \mathrm{C} & -3.33659 & -1.64236 & 0.08273 \\ \mathrm{C} & -2.21558 & -2.23816 & 0.70939 \\ \mathrm{~N} & -1.01184 & -2.34793 & 0.23356 \\ \mathrm{C} & -0.62692 & -1.85784 & -1.10202 \\ \mathrm{C} & 0.05724 & -3.01183 & 1.01821 \\ \mathrm{C} & -8.10008 & -0.63665 & 0.77314 \\ \mathrm{C} & -0.69483 & 0.55905 & -0.36562 \\ \mathrm{C} & -0.06315 & -0.45360 & -1.07168 \\ \mathrm{C} & 2.37122 & -0.14626 & 1.86056 \\ \mathrm{C} & 1.27424 & -0.98425 & 1.86402 \\ \mathrm{C} & 1.29039 & -2.15224 & 1.10274 \\ \mathrm{C} & 2.41607 & -2.47183 & 0.36555 \\ \mathrm{C} & 1.03991 & 2.11158 & -0.98537 \\ \mathrm{C} & -0.14070 & 1.82933 & -0.32221 \\ \mathrm{C} & 3.49993 & -0.45247 & 1.10409 \\ \mathrm{C} & 3.51306 & -1.61630 & 0.36263 \\ \mathrm{C} & 4.68204 & -1.96463 & -0.52324 \\ \mathrm{C} & 2.36132 & 1.13577 & 2.65625 \\ \mathrm{C} & 1.12148 & -0.17735 & -1.74448 \\ \mathrm{C} & 1.66128 & 1.09778 & -1.69964 \\ \mathrm{C} & 2.98570 & 1.36611 & -2.37096 \\ \mathrm{~F} & 3.08707 & 2.63082 & -2.76726\end{array}$




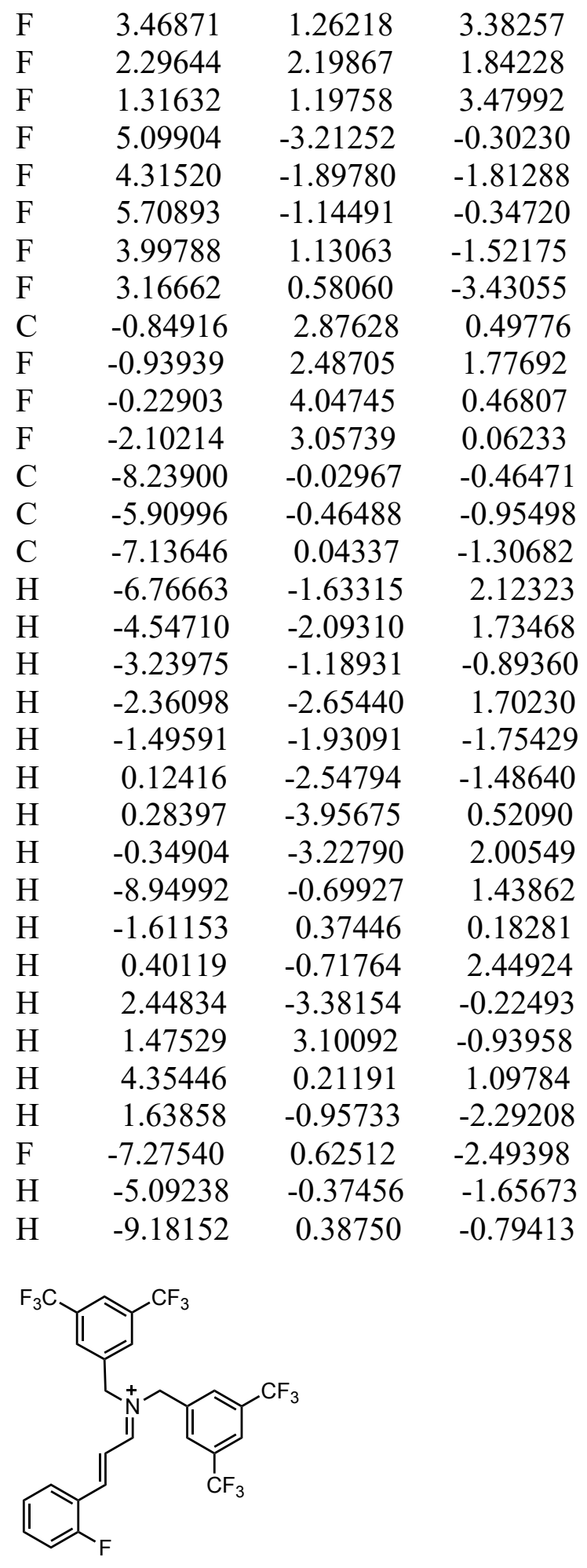

\section{Iminium-17}

M06-2X/def2-TZVP Geometry $\begin{array}{llll}\text { C } & 6.95090 & -1.00326 & 1.05993\end{array}$ 


$\begin{array}{lrrr}\mathrm{C} & 5.84687 & -0.96264 & 0.18872 \\ \mathrm{C} & 4.59875 & -1.51413 & 0.63561 \\ \mathrm{C} & 3.40340 & -1.57684 & -0.01194 \\ \mathrm{C} & 2.31264 & -2.16513 & 0.67354 \\ \mathrm{~N} & 1.09863 & -2.31377 & 0.23486 \\ \mathrm{C} & 0.66978 & -1.88277 & -1.10848 \\ \mathrm{C} & 0.06123 & -2.95708 & 1.07472 \\ \mathrm{C} & 8.17351 & -0.48428 & 0.69300 \\ \mathrm{C} & 0.72999 & 0.56553 & -0.48727 \\ \mathrm{C} & 0.08231 & -0.48804 & -1.11528 \\ \mathrm{C} & -3.43141 & -1.60318 & 0.53202 \\ \mathrm{C} & -2.32997 & -2.45286 & 0.51410 \\ \mathrm{C} & -1.17125 & -2.09820 & 1.18057 \\ \mathrm{C} & -1.12474 & -0.90014 & 1.89182 \\ \mathrm{C} & -1.05846 & 2.06234 & -1.09155 \\ \mathrm{C} & 0.15637 & 1.82730 & -0.47282 \\ \mathrm{C} & -3.38932 & -0.41048 & 1.22526 \\ \mathrm{C} & -2.22580 & -0.06767 & 1.90946 \\ \mathrm{C} & -2.18121 & 1.24961 & 2.64389 \\ \mathrm{C} & -4.64130 & -1.98938 & -0.28052 \\ \mathrm{C} & -1.13684 & -0.25978 & -1.74228 \\ \mathrm{C} & -1.69540 & 1.00811 & -1.72930 \\ \mathrm{C} & -3.05200 & 1.22649 & -2.35270 \\ \mathrm{~F} & -3.25585 & 0.40916 & -3.38397 \\ \mathrm{~F} & -5.66607 & -1.17353 & -0.07491 \\ \mathrm{H} & -0.07885 & -2.60013 & -1.44537 \\ \mathrm{~F} & -4.34526 & -1.96017 & -1.58929 \\ \mathrm{~F} & -5.03359 & -3.23334 & 0.00130 \\ \mathrm{~F} & -2.15038 & 2.27401 & 1.77947 \\ \mathrm{~F} & -3.25617 & 1.41295 & 3.41032 \\ \mathrm{~F} & -1.10135 & 1.34776 & 3.41792 \\ \mathrm{~F} & -4.02445 & 0.99004 & -1.45845 \\ \mathrm{~F} & -3.20053 & 2.47762 & -2.77690 \\ \mathrm{C} & 0.88729 & 2.92348 & 0.25855 \\ \mathrm{~F} & 1.10728 & 2.57035 & 1.53298 \\ \mathrm{~F} & 2.08673 & 3.14941 & -0.29058 \\ \mathrm{~F} & 0.21454 & 4.06604 & 0.25995 \\ \mathrm{C} & 8.32420 & 0.09282 & -0.56511 \\ \mathrm{C} & 6.04822 & -0.37167 & -1.06662 \\ \mathrm{H} & 7.25910 & 0.15155 & -1.45378 \\ \mathrm{H} & 4.63720 & -1.93033 & 1.63997 \\ \mathrm{H} & 3.27717 & -1.17508 & -1.00402 \\ \mathrm{H} & & -3.14465 & 2.05266\end{array}$




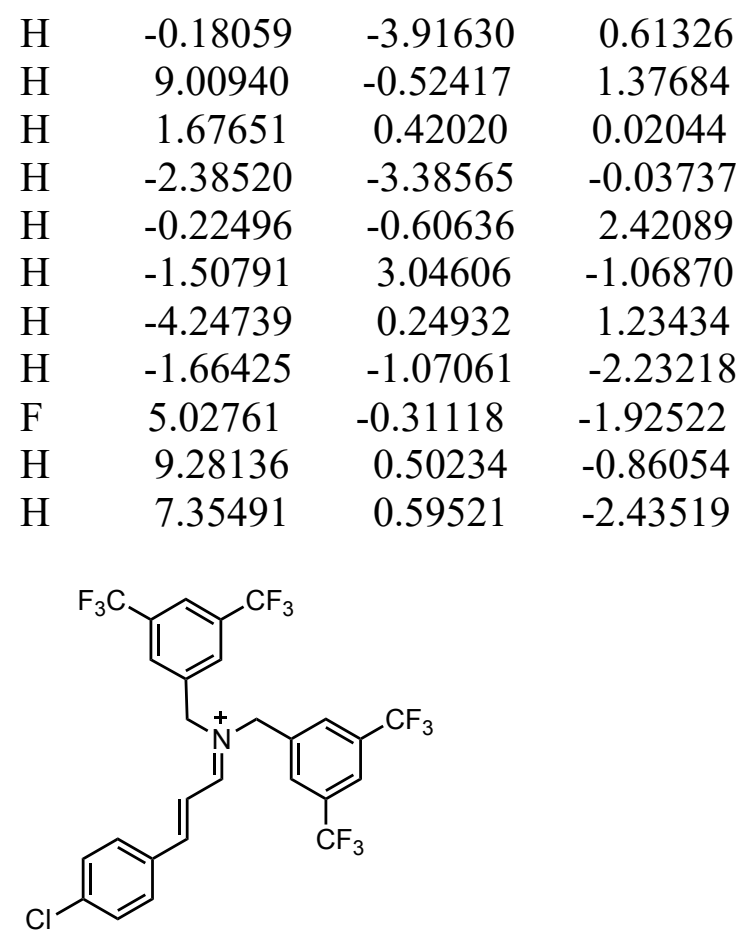

\section{Iminium-18}

$\begin{array}{lrrr}\text { M06-2X/def2-TZVP Geometry } & \\ \mathrm{C} & 6.54735 & -1.25099 & 1.15257 \\ \mathrm{C} & 5.44072 & -1.16071 & 0.29453 \\ \mathrm{C} & 4.18734 & -1.69516 & 0.74174 \\ \mathrm{C} & 2.99913 & -1.69489 & 0.07535 \\ \mathrm{C} & 1.87509 & -2.27062 & 0.70689 \\ \mathrm{~N} & 0.66672 & -2.37177 & 0.23432 \\ \mathrm{C} & 0.28614 & -1.89354 & -1.10535 \\ \mathrm{C} & -0.40838 & -3.01250 & 1.02771 \\ \mathrm{C} & 7.77799 & -0.75181 & 0.78099 \\ \mathrm{C} & -1.44488 & -0.20251 & -1.76823 \\ \mathrm{C} & -0.26346 & -0.48339 & -1.09225 \\ \mathrm{C} & -2.67539 & -0.10371 & 1.85301 \\ \mathrm{C} & -1.59110 & -0.95831 & 1.85916 \\ \mathrm{C} & -1.62844 & -2.13341 & 1.10990 \\ \mathrm{C} & -2.76244 & -2.44242 & 0.38090 \\ \mathrm{C} & -1.34152 & 2.09380 & -1.03458 \\ \mathrm{C} & -1.97286 & 1.07810 & -1.73713 \\ \mathrm{C} & -3.81203 & -0.39955 & 1.10461 \\ \mathrm{C} & -3.84594 & -1.57002 & 0.37406 \\ \mathrm{C} & -5.02416 & -1.90830 & -0.50333 \\ \mathrm{C} & -2.64039 & 1.18591 & 2.63579 \\ \mathrm{C} & 0.37810 & 0.53103 & -0.39743 \\ \mathrm{C} & -0.16326 & 1.80714 & -0.36878\end{array}$




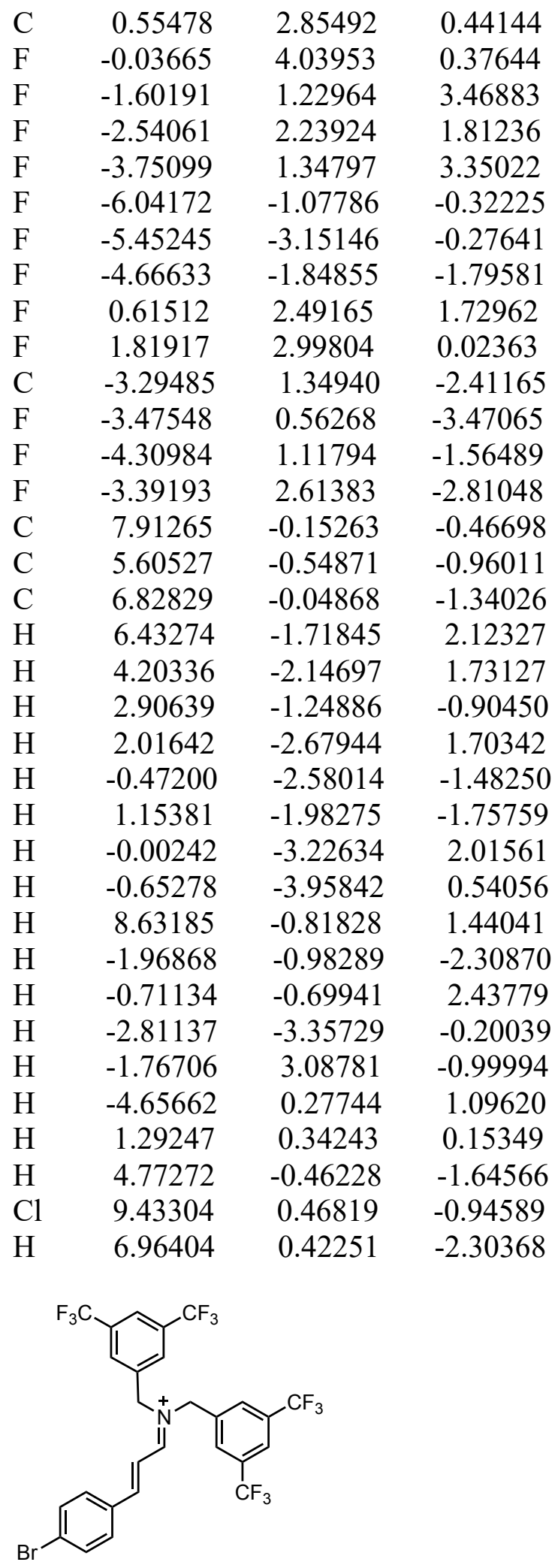

Iminium-19 


\begin{tabular}{|c|c|c|c|}
\hline \multicolumn{4}{|c|}{ M06-2X/def2-TZVP Geometry } \\
\hline $\mathrm{C}$ & 5.97999 & -1.36418 & 1.36627 \\
\hline $\mathrm{C}$ & 4.89030 & -1.23313 & 0.49255 \\
\hline $\mathrm{C}$ & 3.61793 & -1.74862 & 0.90847 \\
\hline $\mathrm{C}$ & 2.44696 & -1.72786 & 0.21295 \\
\hline $\mathrm{C}$ & 1.30042 & -2.29738 & 0.80914 \\
\hline $\mathrm{N}$ & 0.10630 & -2.38627 & 0.29960 \\
\hline $\mathrm{C}$ & -0.22893 & -1.89665 & -1.04771 \\
\hline $\mathrm{C}$ & -0.99818 & -3.02370 & 1.05498 \\
\hline $\mathrm{C}$ & 7.23093 & -0.89689 & 1.01871 \\
\hline $\mathrm{C}$ & -1.91663 & -0.18404 & -1.76464 \\
\hline $\mathrm{C}$ & -0.76729 & -0.48196 & -1.04211 \\
\hline $\mathrm{C}$ & -3.28184 & -0.11071 & 1.81723 \\
\hline $\mathrm{C}$ & -2.20389 & -0.97255 & 1.85997 \\
\hline $\mathrm{C}$ & -2.21612 & -2.13889 & 1.09654 \\
\hline $\mathrm{C}$ & -3.31990 & -2.43220 & 0.31639 \\
\hline $\mathrm{C}$ & -1.82737 & 2.10314 & -1.00080 \\
\hline $\mathrm{C}$ & -2.43550 & 1.10046 & -1.74154 \\
\hline $\mathrm{C}$ & -4.38654 & -0.39013 & 1.01673 \\
\hline $\mathrm{C}$ & -4.39681 & -1.55286 & 0.27319 \\
\hline $\mathrm{C}$ & -5.54038 & -1.87743 & -0.65363 \\
\hline $\mathrm{C}$ & -3.27241 & 1.16918 & 2.61659 \\
\hline $\mathrm{C}$ & -0.14853 & 0.51935 & -0.30905 \\
\hline $\mathrm{C}$ & -0.68107 & 1.79935 & -0.28851 \\
\hline $\mathrm{C}$ & 0.00845 & 2.83102 & 0.56593 \\
\hline $\mathrm{F}$ & -0.57641 & 4.01869 & 0.49810 \\
\hline $\mathrm{F}$ & -2.27879 & 1.18939 & 3.50370 \\
\hline $\mathrm{F}$ & -3.11628 & 2.23084 & 1.81289 \\
\hline $\mathrm{F}$ & -4.41721 & 1.33707 & 3.27335 \\
\hline $\mathrm{F}$ & -6.55849 & -1.04038 & -0.51058 \\
\hline $\mathrm{F}$ & -5.98666 & -3.11847 & -0.45061 \\
\hline $\mathrm{F}$ & -5.12908 & -1.81475 & -1.93000 \\
\hline $\mathrm{F}$ & 1.28809 & 2.97648 & 0.19900 \\
\hline $\mathrm{F}$ & 0.01804 & 2.44599 & 1.84944 \\
\hline $\mathrm{C}$ & -3.72679 & 1.38793 & -2.46654 \\
\hline $\mathrm{F}$ & -3.79823 & 2.65589 & -2.85930 \\
\hline $\mathrm{F}$ & -3.87069 & 0.61037 & -3.53786 \\
\hline $\mathrm{F}$ & -4.77653 & 1.15806 & -1.66268 \\
\hline $\mathrm{C}$ & 7.40230 & -0.28731 & -0.21943 \\
\hline $\mathrm{C}$ & 5.09063 & -0.60789 & -0.74987 \\
\hline $\mathrm{C}$ & 6.33364 & -0.13782 & -1.10521 \\
\hline $\mathrm{H}$ & 5.83823 & -1.84076 & 2.32897 \\
\hline $\mathrm{H}$ & 3.60338 & -2.20750 & 1.89478 \\
\hline $\mathrm{H}$ & 2.38522 & -1.27556 & -0.76645 \\
\hline $\mathrm{H}$ & 1.40947 & -2.71302 & 1.80688 \\
\hline $\mathrm{H}$ & -0.98047 & -2.57482 & -1.45212 \\
\hline
\end{tabular}




$\begin{array}{lrrr}\mathrm{H} & 0.65771 & -1.98877 & -1.67349 \\ \mathrm{H} & -0.62730 & -3.24110 & 2.05577 \\ \mathrm{H} & -1.22991 & -3.96766 & 0.55789 \\ \mathrm{H} & 8.06884 & -1.00141 & 1.69345 \\ \mathrm{H} & -2.42418 & -0.95406 & -2.33462 \\ \mathrm{H} & -1.34814 & -0.72557 & 2.47845 \\ \mathrm{H} & -3.35000 & -3.34074 & -0.27603 \\ \mathrm{H} & -2.24672 & 3.10003 & -0.97229 \\ \mathrm{H} & -5.22531 & 0.29315 & 0.97901 \\ \mathrm{H} & 0.73927 & 0.31635 & 0.27906 \\ \mathrm{H} & 4.27140 & -0.48696 & -1.44611 \\ \mathrm{Br} & 9.09496 & 0.33823 & -0.71650 \\ \mathrm{H} & 6.49081 & 0.34190 & -2.06110\end{array}$




\section{Out-of-sample predictions}

The steps for ee prediction include: 1) locating the ground state of the targeted reaction variable by DFT, 2) acquiring the key molecular features necessary for prediction and 3) re-creating the $E$ imine model and submitting the parameter values to the resulting mathematical equation.

\section{Model Parameters}

The parameters calculated for the systems are reported in separate tables (S24 and S27) and described pictorially in Figure S3 below. We derive the relevant Sterimol parameters from the $E$ iminium ground state structures. The solvent structure was expressed with 2D descriptors, topological charge index 2 (CI) and PEOE5. These values are obtained with the molecular descriptors application available in Maestro. The catalyst was described using three parameters $\operatorname{AREA}(\theta)$, Sterimol L, and the $\mathrm{P}-\mathrm{O}$ asymmetric stretching intensity, $\mathrm{iPO}_{\text {as. }}$ The LUMO energy was the single nucleophile parameter required for prediction.

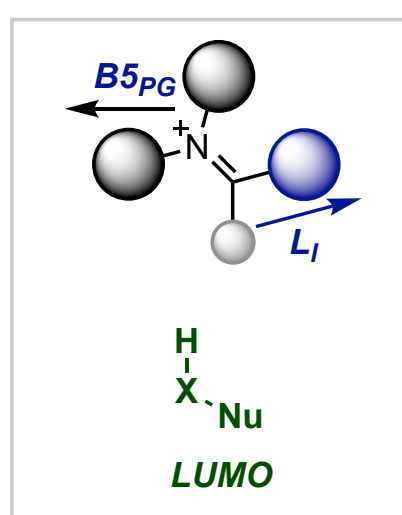

Parameters collected and applied
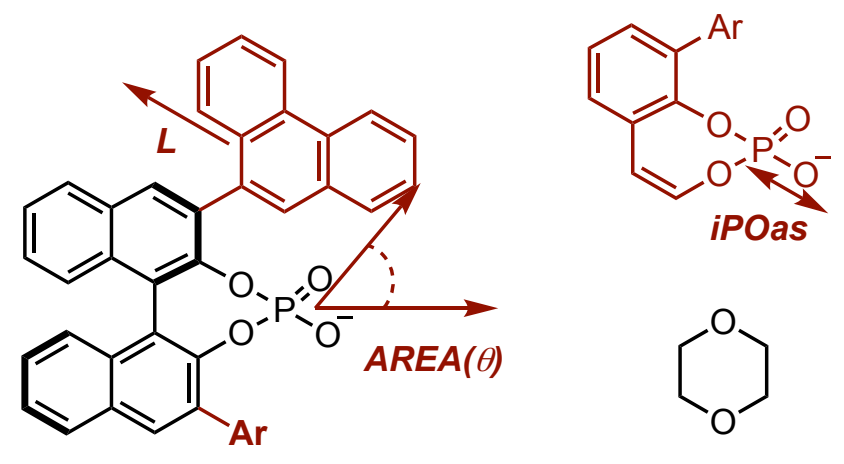<smiles>C1COCCO1</smiles>

CI \& PEOE5

Figure S3. Model parameters employed for enantioselectivity predictions. 


\section{Model re-building}

The correlation was re-created from the 204 data entries available from ref. 7 to build the previously reported $E$-imine linear regression model (Figure S4). This was accomplished using a previously published script implemented in MATLAB $^{\circledR}$ (version R2018b). ${ }^{26}$

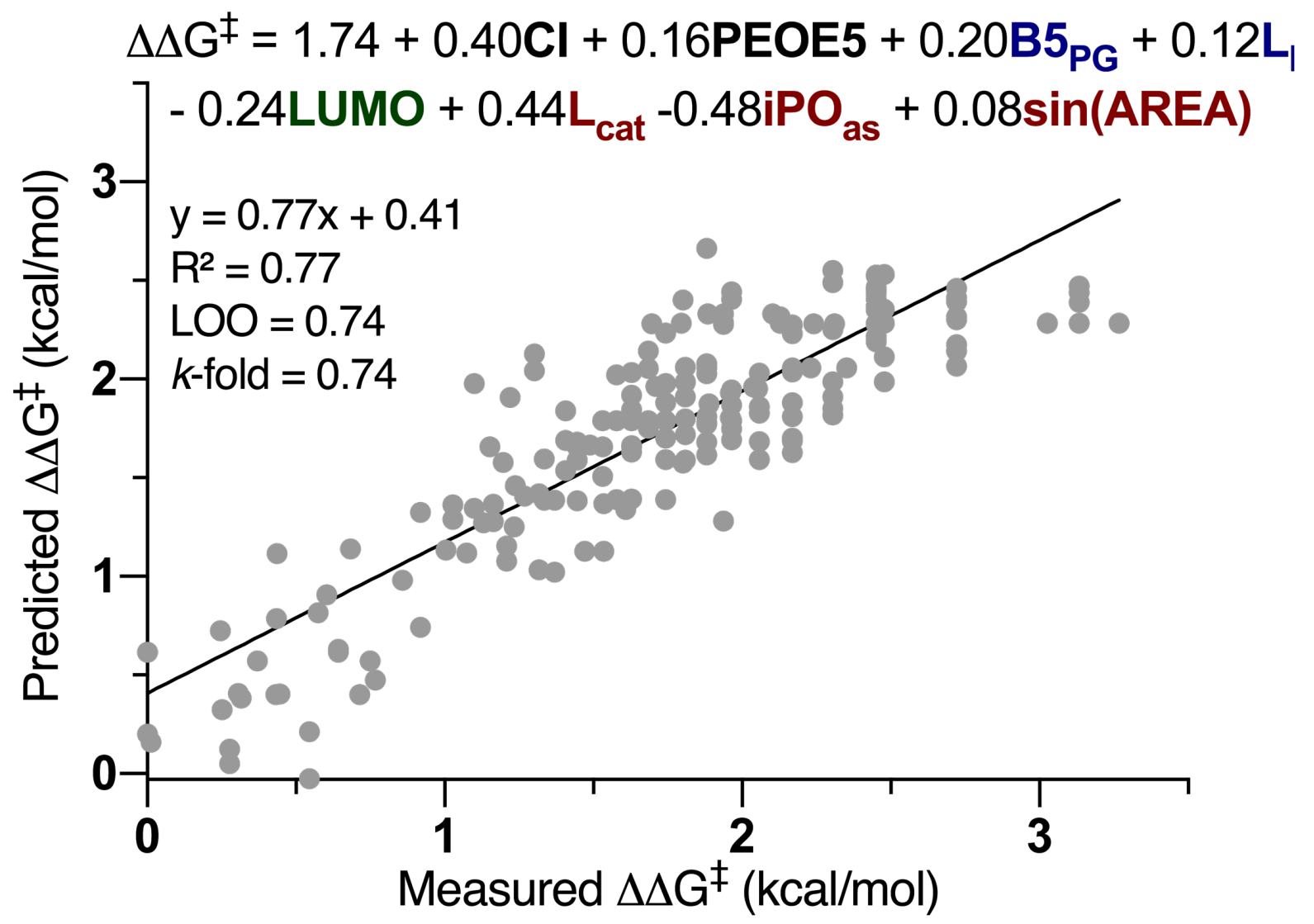

Figure S4. Re-built E-imine model generated from all training dataset from ref. 7. 


\begin{tabular}{|c|c|c|}
\hline Measured $\Delta \Delta \mathrm{G}^{\dagger}$ & Predicted $\Delta \Delta \mathrm{G}^{*}$ & LOO \\
\hline 0.25 & 0.72 & 0.79 \\
\hline 0.64 & 0.63 & 0.63 \\
\hline 1.13 & 1.27 & 1.27 \\
\hline 0.31 & 0.41 & 0.42 \\
\hline 0.37 & 0.57 & 0.59 \\
\hline 0.00 & 0.20 & 0.22 \\
\hline 1.54 & 1.37 & 1.36 \\
\hline 0.64 & 0.62 & 0.61 \\
\hline 0.44 & 1.11 & 1.20 \\
\hline 0.00 & 0.62 & 0.66 \\
\hline 0.00 & 0.62 & 0.66 \\
\hline 1.94 & 1.28 & 1.27 \\
\hline 1.80 & 1.57 & 1.56 \\
\hline 1.61 & 1.34 & 1.33 \\
\hline 1.16 & 1.37 & 1.37 \\
\hline 1.54 & 1.13 & 1.12 \\
\hline 1.32 & 1.03 & 1.02 \\
\hline 1.47 & 1.13 & 1.12 \\
\hline 1.32 & 1.42 & 1.42 \\
\hline 1.23 & 1.25 & 1.25 \\
\hline 1.16 & 1.28 & 1.28 \\
\hline 1.20 & 1.58 & 1.60 \\
\hline 2.06 & 1.59 & 1.58 \\
\hline 1.74 & 1.59 & 1.59 \\
\hline 1.63 & 1.63 & 1.63 \\
\hline 1.88 & 1.68 & 1.68 \\
\hline 1.88 & 1.62 & 1.61 \\
\hline 1.33 & 1.60 & 1.60 \\
\hline 1.96 & 1.95 & 1.95 \\
\hline 1.81 & 1.80 & 1.80 \\
\hline 2.17 & 1.63 & 1.61 \\
\hline 1.96 & 1.87 & 1.87 \\
\hline 1.88 & 1.78 & 1.78 \\
\hline 1.63 & 1.66 & 1.66 \\
\hline 1.96 & 1.75 & 1.74 \\
\hline 1.68 & 1.75 & 1.75 \\
\hline 1.81 & 1.72 & 1.72 \\
\hline 1.41 & 1.84 & 1.85 \\
\hline 1.45 & 1.59 & 1.59 \\
\hline 1.81 & 1.59 & 1.58 \\
\hline 1.74 & 1.98 & 1.98 \\
\hline 0.92 & 1.32 & 1.36 \\
\hline 0.54 & 0.21 & 0.17 \\
\hline 0.45 & 0.40 & 0.40 \\
\hline 1.81 & 1.91 & 1.91 \\
\hline 3.13 & 2.29 & 2.27 \\
\hline 3.27 & 2.29 & 2.27 \\
\hline 3.03 & 2.29 & 2.27 \\
\hline 3.03 & 2.29 & 2.27 \\
\hline 2.48 & 2.29 & 2.28 \\
\hline 1.80 & 2.29 & 2.29 \\
\hline 2.48 & 2.36 & 2.35 \\
\hline 3.13 & 2.44 & 2.42 \\
\hline 3.13 & 2.47 & 2.45 \\
\hline 1.96 & 2.44 & 2.46 \\
\hline
\end{tabular}




\begin{tabular}{|c|c|c|}
\hline 2.72 & 2.41 & 2.40 \\
\hline 2.48 & 2.53 & 2.53 \\
\hline 2.72 & 2.32 & 2.31 \\
\hline 2.72 & 2.30 & 2.29 \\
\hline 2.30 & 2.25 & 2.25 \\
\hline 3.13 & 2.39 & 2.37 \\
\hline 2.30 & 2.55 & 2.56 \\
\hline 1.88 & 2.03 & 2.03 \\
\hline 2.17 & 2.27 & 2.28 \\
\hline 2.17 & 2.04 & 2.03 \\
\hline 2.06 & 2.03 & 2.03 \\
\hline 2.72 & 2.39 & 2.39 \\
\hline 2.05 & 1.95 & 1.95 \\
\hline 0.28 & 0.12 & 0.10 \\
\hline 0.28 & 0.05 & 0.00 \\
\hline 0.43 & 0.40 & 0.40 \\
\hline 0.54 & -0.03 & -0.09 \\
\hline 0.68 & 1.14 & 1.18 \\
\hline 1.00 & 1.13 & 1.15 \\
\hline 1.21 & 1.15 & 1.15 \\
\hline 1.45 & 1.38 & 1.38 \\
\hline 1.53 & 1.51 & 1.51 \\
\hline 1.41 & 1.54 & 1.55 \\
\hline 1.37 & 1.39 & 1.39 \\
\hline 1.58 & 1.39 & 1.38 \\
\hline 1.63 & 1.39 & 1.37 \\
\hline 1.74 & 1.39 & 1.36 \\
\hline 1.33 & 1.39 & 1.39 \\
\hline 1.10 & 1.35 & 1.37 \\
\hline 1.96 & 1.80 & 1.80 \\
\hline 1.96 & 1.80 & 1.80 \\
\hline 1.96 & 1.80 & 1.80 \\
\hline 1.96 & 1.93 & 1.93 \\
\hline 2.04 & 1.96 & 1.96 \\
\hline 1.89 & 1.88 & 1.87 \\
\hline 1.71 & 1.96 & 1.97 \\
\hline 2.35 & 2.06 & 2.04 \\
\hline 2.23 & 2.06 & 2.05 \\
\hline 1.22 & 1.91 & 1.93 \\
\hline 0.57 & 0.82 & 0.85 \\
\hline 0.75 & 0.57 & 0.55 \\
\hline 0.92 & 0.74 & 0.71 \\
\hline 1.03 & 1.36 & 1.38 \\
\hline 1.24 & 1.46 & 1.47 \\
\hline 1.30 & 2.04 & 2.07 \\
\hline 1.53 & 1.79 & 1.80 \\
\hline 1.03 & 1.29 & 1.31 \\
\hline 1.49 & 1.67 & 1.67 \\
\hline 1.58 & 1.79 & 1.80 \\
\hline 1.63 & 1.79 & 1.80 \\
\hline 1.74 & 1.79 & 1.79 \\
\hline 1.96 & 1.79 & 1.78 \\
\hline 1.68 & 1.79 & 1.79 \\
\hline 1.96 & 1.79 & 1.78 \\
\hline 2.06 & 1.86 & 1.85 \\
\hline
\end{tabular}




\begin{tabular}{|c|c|c|}
\hline 1.63 & 1.92 & 1.93 \\
\hline 1.74 & 1.98 & 1.99 \\
\hline 1.74 & 1.79 & 1.79 \\
\hline 1.63 & 2.03 & 2.06 \\
\hline 2.72 & 2.07 & 2.03 \\
\hline 1.88 & 1.81 & 1.81 \\
\hline 2.06 & 1.83 & 1.82 \\
\hline 1.63 & 1.85 & 1.86 \\
\hline 1.88 & 1.77 & 1.77 \\
\hline 2.30 & 1.82 & 1.79 \\
\hline 2.17 & 1.88 & 1.86 \\
\hline 0.43 & 0.79 & 0.83 \\
\hline 1.89 & 2.33 & 2.34 \\
\hline 1.89 & 2.33 & 2.34 \\
\hline 1.89 & 2.33 & 2.34 \\
\hline 2.10 & 2.33 & 2.34 \\
\hline 1.94 & 2.33 & 2.34 \\
\hline 2.13 & 2.32 & 2.32 \\
\hline 2.13 & 2.31 & 2.31 \\
\hline 1.94 & 2.29 & 2.29 \\
\hline 2.45 & 2.28 & 2.28 \\
\hline 2.31 & 2.28 & 2.28 \\
\hline 2.24 & 2.28 & 2.28 \\
\hline 2.45 & 2.28 & 2.28 \\
\hline 2.45 & 2.28 & 2.28 \\
\hline 2.45 & 2.28 & 2.28 \\
\hline 2.45 & 2.28 & 2.28 \\
\hline 2.45 & 2.28 & 2.28 \\
\hline 2.45 & 2.28 & 2.27 \\
\hline 1.80 & 2.40 & 2.41 \\
\hline 2.45 & 2.53 & 2.53 \\
\hline 1.70 & 2.28 & 2.29 \\
\hline 1.94 & 2.28 & 2.28 \\
\hline 2.45 & 2.41 & 2.41 \\
\hline 2.45 & 2.35 & 2.35 \\
\hline 2.13 & 2.28 & 2.29 \\
\hline 2.45 & 2.44 & 2.44 \\
\hline 2.13 & 2.28 & 2.29 \\
\hline 2.45 & 2.47 & 2.47 \\
\hline 1.94 & 2.28 & 2.29 \\
\hline 2.45 & 2.37 & 2.37 \\
\hline 2.45 & 2.45 & 2.45 \\
\hline 2.45 & 2.52 & 2.53 \\
\hline 2.45 & 2.19 & 2.18 \\
\hline 2.45 & 2.22 & 2.21 \\
\hline 0.77 & 0.47 & 0.44 \\
\hline 0.25 & 0.32 & 0.33 \\
\hline 0.72 & 0.40 & 0.35 \\
\hline 1.37 & 1.02 & 1.01 \\
\hline 0.01 & 0.16 & 0.18 \\
\hline 1.74 & 1.70 & 1.70 \\
\hline 1.07 & 1.12 & 1.12 \\
\hline 1.58 & 2.02 & 2.05 \\
\hline 0.32 & 0.38 & 0.39 \\
\hline
\end{tabular}




\begin{tabular}{|c|c|c|}
\hline 1.88 & 2.08 & 2.08 \\
\hline 1.88 & 2.08 & 2.08 \\
\hline 1.68 & 2.05 & 2.07 \\
\hline 1.88 & 2.06 & 2.06 \\
\hline 2.17 & 1.69 & 1.67 \\
\hline 1.81 & 2.06 & 2.07 \\
\hline 2.06 & 1.68 & 1.67 \\
\hline 2.17 & 1.81 & 1.79 \\
\hline 1.96 & 1.69 & 1.68 \\
\hline 2.30 & 1.85 & 1.82 \\
\hline 2.17 & 1.70 & 1.68 \\
\hline 1.41 & 1.69 & 1.70 \\
\hline 0.86 & 0.98 & 0.98 \\
\hline 1.45 & 1.66 & 1.66 \\
\hline 1.10 & 1.98 & 2.02 \\
\hline 1.21 & 1.08 & 1.07 \\
\hline 1.15 & 1.66 & 1.67 \\
\hline 1.27 & 1.41 & 1.42 \\
\hline 1.53 & 1.66 & 1.66 \\
\hline 1.74 & 1.88 & 1.88 \\
\hline 1.45 & 1.68 & 1.69 \\
\hline 1.63 & 1.66 & 1.66 \\
\hline 2.48 & 1.99 & 1.97 \\
\hline 2.30 & 1.99 & 1.98 \\
\hline 2.17 & 2.06 & 2.05 \\
\hline 2.72 & 2.14 & 2.12 \\
\hline 2.72 & 2.17 & 2.15 \\
\hline 2.17 & 2.23 & 2.24 \\
\hline 1.81 & 1.99 & 1.99 \\
\hline 1.81 & 1.98 & 1.99 \\
\hline 1.74 & 2.23 & 2.26 \\
\hline 1.68 & 2.14 & 2.16 \\
\hline 2.48 & 2.11 & 2.10 \\
\hline 2.30 & 2.49 & 2.51 \\
\hline 1.96 & 2.41 & 2.44 \\
\hline 2.72 & 2.46 & 2.44 \\
\hline 0.60 & 0.91 & 0.93 \\
\hline 2.30 & 1.91 & 1.89 \\
\hline 1.88 & 2.66 & 2.69 \\
\hline 1.30 & 2.13 & 2.15 \\
\hline
\end{tabular}




\section{Deploying the correlation}

We evaluated the ability to transfer the mechanistic principles leading to enantioselective catalysis captured by a previously reported statistical model ( $E$ imine model as defined in ref. 7 ) to genuinely different structural motifs not contained in the training dataset. Treating the test reactions as virtual predictions the collected parameters were submitted to the equation in Figure S4. The ability to predict was determined by both enantioselectivity values and the average absolute $\Delta \Delta \mathrm{G}^{\neq}$error $\left(\Delta \Delta \mathrm{G}^{\neq}\right.$error $=$absolute $($model measured - experimentally measured $/$no. of examples $)$).

\section{Hydrogenation}

Table S22. Experimental parameters for the hydrogenation reaction.

\begin{tabular}{|ccccc|}
\hline Iminium & Nucleophile & Catalyst & Solvent & Temperature $\left({ }^{\circ} \mathrm{C}\right)$ \\
\hline 1 & Diethyl 1,4-dihydro-2,6-dimethyl-3,5-pyridinedicarboxylate & TRIP & dioxane & 50 \\
2 & Diethyl 1,4-dihydro-2,6-dimethyl-3,5-pyridinedicarboxylate & TRIP & dioxane & 50 \\
3 & Diethyl 1,4-dihydro-2,6-dimethyl-3,5-pyridinedicarboxylate & TRIP & dioxane & 50 \\
4 & Diethyl 1,4-dihydro-2,6-dimethyl-3,5-pyridinedicarboxylate & TRIP & dioxane & 50 \\
5 & Diethyl 1,4-dihydro-2,6-dimethyl-3,5-pyridinedicarboxylate & TRIP & dioxane & 50 \\
6 & Diethyl 1,4-dihydro-2,6-dimethyl-3,5-pyridinedicarboxylate & TRIP & dioxane & 50 \\
\hline
\end{tabular}

Table S23. Experimental data for the hydrogenation reaction.

\begin{tabular}{|cccc|}
\hline Experimental ee $\%$ & $\Delta \Delta \mathrm{G}^{\ddagger}$ Measured $(\mathrm{kcal} / \mathrm{mol})$ & Predicted ee $\%$ & $\Delta \Delta \mathrm{G}^{\ddagger}$ Predicted $(\mathrm{kcal} / \mathrm{mol})$ \\
\hline 96 & 2.50 & 92 & 2.03 \\
98 & 2.95 & 93 & 2.17 \\
98 & 2.95 & 93 & 2.09 \\
96 & 2.50 & 93 & 2.11 \\
98 & 2.95 & 93 & 2.08 \\
99 & 3.40 & 94 & 2.21 \\
\hline
\end{tabular}

Table S24. Key parameters required for hydrogenation reaction prediction.

\begin{tabular}{|cccccccc|}
\hline CI & PEOE5 & B5PG & LL & LUMO & Lcat & iPOSas & sin(AREA) \\
\hline 0 & 0 & 4.46 & 10.03 & -0.01579 & 4.69 & 174.1557 & 0.67022918 \\
0 & 0 & 4.46 & 10.94 & -0.01579 & 4.69 & 174.1557 & 0.67022918 \\
0 & 0 & 4.46 & 10.4 & -0.01579 & 4.69 & 174.1557 & 0.67022918 \\
0 & 0 & 4.46 & 10.53 & -0.01579 & 4.69 & 174.1557 & 0.67022918 \\
0 & 0 & 4.46 & 10.36 & -0.01579 & 4.69 & 174.1557 & 0.67022918 \\
0 & 0 & 4.46 & 11.17 & -0.01579 & 4.69 & 174.1557 & 0.67022918 \\
\hline
\end{tabular}

$\mathbf{C I}=$ topological charge index 2 


\section{Epoxidation}

Table S25. Experimental parameters for the epoxidation reaction.

\begin{tabular}{|ccccc|}
\hline Iminium & Nucleophile & Catalyst & Solvent & Temperature $\left({ }^{\circ} \mathrm{C}\right)$ \\
\hline 7 & tBuOOH & TRIP & dioxane & 35 \\
8 & tBuOOH & TRIP & dioxane & 35 \\
9 & tBuOOH & TRIP & dioxane & 35 \\
10 & tBuOOH & TRIP & dioxane & 35 \\
11 & tBuOOH & TRIP & dioxane & 35 \\
12 & tBuOOH & TRIP & dioxane & 35 \\
13 & tBuOOH & TRIP & dioxane & 35 \\
14 & tBuOOH & TRIP & dioxane & 35 \\
15 & tBuOOH & TRIP & dioxane & 35 \\
16 & tBuOOH & TRIP & dioxane & 35 \\
17 & tBuOOH & TRIP & dioxane & 35 \\
18 & tBuOOH & TRIP & dioxane & 35 \\
19 & tBuOOH & TRIP & dioxane & 35 \\
\hline
\end{tabular}

Table S26. Experimental data for the epoxidation reaction.

\begin{tabular}{|cccc|}
\hline Experimental ee $\%$ & $\Delta \Delta \mathrm{G}^{\ddagger}$ Measured $(\mathrm{kcal} / \mathrm{mol})$ & Predicted ee $\%$ & $\Delta \Delta \mathrm{G}^{\ddagger}$ Predicted $(\mathrm{kcal} / \mathrm{mol})$ \\
\hline 91 & 1.87 & 89 & 1.71 \\
96 & 2.38 & 93 & 2.00 \\
91 & 1.87 & 89 & 1.71 \\
91 & 1.87 & 96 & 2.37 \\
92 & 1.94 & 91 & 1.87 \\
92 & 1.94 & 89 & 1.75 \\
91 & 1.87 & 89 & 1.71 \\
90 & 1.80 & 96 & 2.39 \\
94 & 2.13 & 90 & 1.80 \\
84 & 1.49 & 89 & 1.71 \\
91 & 1.87 & 88 & 1.70 \\
86 & 1.58 & 92 & 1.91 \\
86 & 1.58 & 92 & 1.95 \\
\hline
\end{tabular}


Table S27. Key parameters required for epoxidation reaction prediction.

\begin{tabular}{|cccccccc|}
\hline CI & PEOE5 & B5PG & LL & LUMO & Lcat & iPOSas & sin(AREA) \\
\hline 0 & 0 & 7.37 & 8.74 & 0.05419 & 4.69 & 174.1557 & 0.67022918 \\
0 & 0 & 7.37 & 10.56 & 0.05419 & 4.69 & 174.1557 & 0.67022918 \\
0 & 0 & 7.38 & 8.78 & 0.05419 & 4.69 & 174.1557 & 0.67022918 \\
0 & 0 & 7.37 & 12.94 & 0.05419 & 4.69 & 174.1557 & 0.67022918 \\
0 & 0 & 7.38 & 9.78 & 0.05419 & 4.69 & 174.1557 & 0.67022918 \\
0 & 0 & 7.38 & 9 & 0.05419 & 4.69 & 174.1557 & 0.67022918 \\
0 & 0 & 7.37 & 8.76 & 0.05419 & 4.69 & 174.1557 & 0.67022918 \\
0 & 0 & 7.38 & 13.05 & 0.05419 & 4.69 & 174.1557 & 0.67022918 \\
0 & 0 & 7.37 & 9.33 & 0.05419 & 4.69 & 174.1557 & 0.67022918 \\
0 & 0 & 7.38 & 8.78 & 0.05419 & 4.69 & 174.1557 & 0.67022918 \\
0 & 0 & 7.37 & 8.71 & 0.05419 & 4.69 & 174.1557 & 0.67022918 \\
0 & 0 & 7.37 & 10.02 & 0.05419 & 4.69 & 174.1557 & 0.67022918 \\
0 & 0 & 7.37 & 10.29 & 0.05419 & 4.69 & 174.1557 & 0.67022918 \\
\hline
\end{tabular}

Note: Due to minor conformational differences, $\mathrm{B} 5 \mathrm{PG}$ was measured as the average of the two PG substituents on the Nitrogen atom. 


\section{References}

(1) Frisch, M. J., et al. Gaussian 16; Gaussian, Inc., Wallingford, CT, 2016.

(2) Becke, A. D. Density-functional exchange-energy approximation with correct asymptotic behavior. Phys. Rev. A 1988, 38, 3098.

(3) Lee, C.; Yang, W.; Parr, R. G. Development of the Colle-Salvetti correlation-energy formula into a functional of the electron density. Phys. Rev. B 1988, 37, 785.

(4) Krishnan R.; Binkley J. S.; Seeger R.; Pople J. A. A. Self-consistent molecular orbital methods. XX. A basis set for correlated wave functions. J. Chem. Phys. 1980, 72, 650.

(5) Gill, P. M. W.; Johnson, B. G.; Pople, J. A.; Frisch, M. J. The performance of the BeckeLee-Yang-Parr (B-LYP) density functional theory with various basis sets. Chem. Phys. Lett. 1992, 197, 499.

(6) Tomasi, J.; Mennucci, B.; Cammi, R. Quantum Mechanical Continuum Solvation Models. Chem. Rev. 2005, 105, 2999.

(7) Reid, J. P.; Sigman, M. S. Holistic prediction of enantioselectivity in asymmetric catalysis. Nature 2019, 571, 343.

(8) Zhao, Y.; Truhlar, D. G. The M06 suite of density functionals for main group thermochemistry, thermochemical kinetics, noncovalent interactions, excited states, and transition elements: two new functionals and systematic testing of four M06-class functionals and 12 other functionals. Theor. Chem. Acc. 2008, 120, 215.

(9) Weigend, F.; Ahlrichs, R. Balanced basis sets of split valence, triple zeta valence and quadruple zeta valence quality for $\mathrm{H}$ to Rn: Design and assessment of accuracy. Phys. Chem. Chem. Phys. 2005, 7, 3297.

(10) Frisch, M. J. et al. Gaussian 09, Revision D.01, Gaussian, Inc.: Wallingford, CT 2013.

(11) Piou, T.; Romanov-Michailidis, F.; Romanova-Michaelides, M.; Jackson, K. E.; Semakul, N.; Taggart, T. D.; Newell, B. S.; Rithner, C. D.; Paton, R. S.; Rovis, T. Correlating Reactivity and Selectivity to Cyclopentadienyl Ligand Properties in Rh(III)-Catalyzed C-H Activation Reactions: An Experimental and Computational Study. J. Am. Chem. Soc. 2017, 139, 1296.

(12) MacroModel, version 11.7, Schrödinger, LLC, New York, NY, 2017.

(13) Harder, E.; Damm, W.; Maple, J.; Wu, C.; Reboul, M.; Xiang, J. Y.; Wang, L.; Lupyan, D.; Dahlgren, M. K.; Knight, J. L.; Kaus, J. W.; Cerutti, D. S.; Krilov, G.; Jorgensen, W. L.; Abel, R.; Friesner, R. A. A Force Field Providing Broad Coverage of Drug-like Small Molecules and Proteins. J. Chem. Theory Comput. 2016, 12, 281.

(14) Chai, J.-D.; Head-Gordon, M. Long-Range Corrected Hybrid Density Functionals with Damped Atom-Atom Dispersion Corrections. Phys. Chem. Chem. Phys. 2008, 10, 6615.

(15) Grimme, S.; Antony, J.; Ehrlich, S.; Krieg, H. A Consistent and Accurate Ab Initio Parametrization of Density Functional Dispersion Correction (DFT-D) for the 94 Elements H-Pu. J. Chem. Phys. 2010, 132, 154104.

(16) Marenich, A. V.; Cramer, C. J.; Truhlar, D. G. Universal Solvation Model Based on Solute Electron Density and on a Continuum Model of the Solvent Defined by the Bulk Dielectric Constant and Atomic Surface Tensions. J. Phys. Chem. B 2009, 113, 6378.

(17) Funes-Ardoiz, I.; Paton, R. S. GoodVibes; GoodVibes v1.0.1, 2016; DOI: 10.5281/Zenodo.60811.

(18) Grimme, S. Supramolecular Binding Thermodynamics by Dispersion-Corrected Density Functional Theory. Chem. - Eur. J. 2012, 18, 9955. 
(19) Ribeiro, R. F.; Marenich, A. V.; Cramer, C. J.; Truhlar, D. G. Use of Solution-Phase Vibrational Frequencies in Continuum Models for the Free Energy of Solvation. J. Phys. Chem. B 2011, 115, 14556.

(20) Neese, F. The Orca Program System. Wires Comput. Mol. Sci. 2012, 2, 73.

(21) Liakos, D. G.; Sparta, M.; Kesharwani, M. K.; Martin, J. M. L.; Neese, F. Exploring the Accuracy Limits of Local Pair Natural Orbital Coupled-Cluster Theory. J. Chem. Theory Comput. 2015, 11, 1525-1539.

(22) Yang, L.; Brazier, J. B.; Hubbard, T. A.; Rogers, D. M.; Cockroft, S. L. Can Dispersion Forces Govern Aromatic Stacking in an Organic Solvent? Angew. Chem., Int. Ed. 2016, 55, 912.

(23) Yang, L.; Adam, C.; Nichol, G. S.; Cockroft, S. L. How much do van der Waals dispersion forces contribute to molecular recognition in solution? Nat. Chem. 2013, 5, 1006.

(24) Luccarelli, J.; Paton, R. S. Hydrogen-Bond Dependent Conformational Switching: A Computational Challenge from Experimental Thermochemistry. J. Org. Chem. 2019, 84, 613.

(25) Krenske, E. H.; Houk, K. N. Aromatic Interactions as Control Elements in Stereoselective Organic Reactions. Acc. Chem. Res. 2013, 46, 979.

(26) Guo, J.-Y.; Minko, Y.; Santiago, C. B.; Sigman, M. S. Developing Comprehensive Computational Parameter Sets To Describe the Performance of Pyridine-Oxazoline and Related Ligands. ACS Catal. 2017, 7, 4144. 